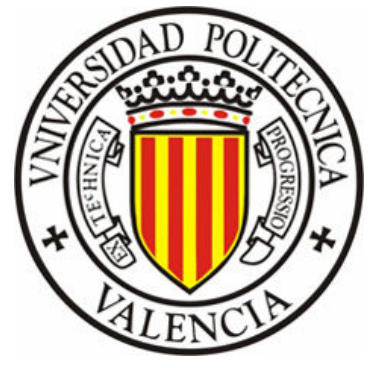

TESIS DOCTORAL:

\title{
EFECTO DE LA BIOFUMIGACIÓN Y BIOSOLARIZACIÓN EN EL CONTROL DE AGENTES FITOPATÓGENOS
}

Presentada por:

María Jesús Zanón Alonso

Dirigida por:

Dra. Ma Concepción Jordá Gutiérrez 

La Dra. Dña. Ma Concepcción Jordá Gutiérrez, catedrática de la Universidad Politécnica de Valencia

\section{INFORMA:}

Que la memoria de tesis titulada "Efecto de la biofumigación y biosolarización en el control de agentes fitopatógenos" realizada por Dña. María Jesús Zanón Alonso puede ser presentada para su exposición y defensa pública para optar al grado de Doctor en el Departamento de Ecosistemas Agroforestales de la Universidad Politécnica de Valencia.

Fdo. Dra. Dña. Ma Concepción Jordá

Valencia, Enero 2009 

A mis padres, a mi hermana Miriam y a Beltrán 



\section{INDICE}

Resumen

Abstract

Resum

I. INTRODUCCIÓN

1. Desinfección de los suelos y sustratos: control de patógenos 1

1.1. Utilización óptima de los métodos más comunes de desinfección 2

de suelos

1.2. Problemática del BM 4

1.3. Alternativas al BM 9

1.3.1. Alternativas químicas al BM 11

1.3.2. Alternativas no químicas: solarización 17

1.3.2.1. Beneficios adicionales de la solarización: incremento de crecimiento

1.3.2.2. Solarización estructural

1.3.2.3. Condiciones de la técnica 25

1.3.2.4. Mecanismos para el control de enfermedades mediante solarización

1.3.2.5. Limitaciones de la solarización 27

1.3.3. Alternativas no químicas: biofumigación 28

1.3.3.1. Condiciones de la técnica 32

1.3.3.2. Materia orgánica y biofumigación 33

1.3.3.3. Efectos de la biofumigación: problemática de los restos de cosechas

1.3.4. Combinación de las técnicas expuestas $\quad 45$

1.3.5. Agentes de control biológico $\quad 54$

1.3.5.1. Principales agentes de control biológico 55

1.3.5.2. Modos de acción y aplicación $\quad 62$

2. Patógenos ensayados 66

2.1. Ralstonia solanacearum 66

2.1.1. Caracterización bacteriana 68

2.1.2. Ciclo del patógeno $\quad 72$

2.1.3. Síntomatología relacionada y patogenicidad 73

2.1.4. Fuentes de inóculo, control y prevención 74

2.1.5. Metodología de diagnóstico 81

2.2. Clavibacter michiganensis subsp. michiganensis 83

2.2.1. Caracterización bacteriana $\quad 84$

2.2.2. Ciclo del patógeno $\quad 85$

2.2.3. Sintomatología relacionada y patogenicidad 86

2.2.4. Fuentes de inóculo, control y prevención $\quad 89$

2.2.5. Metodología de diagnóstico 93

2.3. Mycosphaerella brassicicola 93 
2.3.1. Clasificación fúngica $\quad 94$

2.3.2. Ciclo del patógeno 94

2.3.3. Sintomatología relacionada 95

2.3.4. Fuentes de inóculo, control y prevención 96

II. JUSTIFICACIÓN Y OBJETIVOS 99

III. MATERIAL Y MÉTODOS

1. Biofumigación y biosolarización en condiciones controladas 101

1.1. Medios de cultivo y crecimiento de cepas bacterianas 101

1.1.1. Ralstonia solanacearum 101

1.1.2. C.m.michiganensis 102

1.2. Reacción de hipersensibilidad en hojas de tabaco 103

1.3. Inoculación en plantas de tomate: infección controlada 105

1.3.1. Técnica serológica Double Antiserum Sandwich- Enzyme Linked Immunosorbent Assay (DAS-ELISA) 106

1.4. Microscopía Electrónica de Barrido (SEM) 109

1.5. Tratamiento en macetas: adición de restos de tomate como enmienda orgánica $\quad 110$

1.5.1. Diseño de la experiencia de biofumigación y biosolarización en condiciones de invernadero $\quad 110$

1.5.2. Análisis estadísticos 113

1.6. Introducción y recuperación de cepas bacterianas en sustratos infectados artificialmente 114

1.7. Determinación de la supervivencia de los patógenos en asociación con tejidos vegetales 116

1.8. Identificación de aislados bacterianos mediante PCR y secuenciación 118

2. Biocontrol de Mycosphaerella brassicicola: efecto de diferentes tratamientos sobre restos de coles de Bruselas $\quad 122$

2.1. Experiencia en campo 122

2.2. Aplicación de tratamientos 128

2.3. Muestreos y procesado de muestras 129

2.4. Conteo de esporas 130

2.4.1. Análisis estadísticos 131

2.5. Cuantificación de ADN: PCR en tiempo real 131

2.5.1. Procesado de muestras 131

2.5.2. Extracción de ADN 132

2.5.3. PCR en tiempo real 132

2.5.4. Análisis estadísticos 133

IV. RESULTADOS Y DISCUSIÓN

1. Clavibacter michiganensis subs. michiganensis $\quad 135$

1.1. Crecimiento en placa y test de patogenicidad en tabaco 135 
1.2. Inoculación artificial en plantas de tomate: sintomatología asociada

1.3. Microscopía electrónica de barrido de tallos de tomate inoculados artificialmente

1.4. Diseño de la experiencia de biofumigación y biosolarización en condiciones de invernadero

1.4.1. Tratamiento de biofumigación en macetas: $25^{\circ} \mathrm{C}$

1.4.2. Tratamiento de biosolarización en macetas: $45^{\circ} \mathrm{C} \quad 152$

1.5. Introducción y recuperación de C.m.michiganensis en substratos infectados artificialmente

1.6. Determinación de la supervivencia de C.m.michiganensis en asociación con tejidos vegetales

2.1. Crecimiento en placa y test de patogenicidad en tabaco 169

2.2. Inoculación artificial en plantas de tomate: sintomatología asociada 172

2.3. Microscopía electrónica de barrido de tallos de tomate inoculados artificialmente

2.4. Diseño de la experiencia de biofumigación y biosolarización en condiciones de invernadero

$\begin{array}{lll}\text { 2.4.1. } & \text { Tratamiento de biofumigación en macetas: } 25^{\circ} \mathrm{C} & 176 \\ \text { 2.4.2. } & \text { Tratamiento de biosolarización en macetas: } 45^{\circ} \mathrm{C} & 181\end{array}$

2.5. Introducción y recuperación de $R$. solanacearum en substratos infectados artificialmente

2.6. Determinación de la supervivencia de $R$. solanacearum en asociación con tejidos vegetales

3. Biofumigación y biosolarización en el control de bacterias fitopatógenas: discusión general

4. Efecto de diferentes tratamientos sobre restos de coles de Bruselas para el control de la enfermedad de mancha en anillo causada por Mycosphaerella brassicicola

4.1. Experiencia en campo

4.1.1. Lesiones en hojas 193

4.1.2. Conteo de esporas 196

4.1.3. Cuantificación de ADN: PCR en tiempo real 199

4.1.4. Descomposición de las hojas en función de los tratamientos 202

4.1.5. Efectos observados en los packs de hojas ensayados 203

4.2. Control de M. brassicicola en restos de coles de Bruselas: Discusión general

V. CONCLUSIONES 209

CONCLUSIONS 213

$\begin{array}{ll}\text { VI. BIBLIOGRAFÍA } & 217\end{array}$ 
VII. ANEJOS

1. Identificación de muestras del trabajo en campo 257

2. Volumen de suspensión aplicada por pulverización y tratamiento 265

3. Estudio de lesiones en hojas 267

4. Conteo de esporas 279

5. Resultados de cuantificación por Taqman PCR 297

6. Tabla resumen de resultados del ensayo en campo 301

\section{ÍNDICE DE TABLAS}

Tabla 1 Calendario para la eliminación del uso de bromuro de metilo como fumigante de suelos acordado en septiembre de 1997

Tabla 2 Cultivos con mayor consumo de BM en España en el año 1995

Tabla 3 BM concedido como usos críticos para España en el año 2005

Tabla 4 BM concedido como usos críticos para España en el año 2008

Tabla 5 Alternativas al bromuro de metilo y su empleo en España

Tabla 6 Compuestos encontrados asociados a plantas de tomate

Tabla 7 Algunas alternativas al BM ensayadas durante los últimos años en España

Tabla 8 Aplicación de control biológico en algunas investigaciones realizadas en España

Tabla 9 Principales huéspedes de $R$. solanacearum 67

Tabla 10 Características bioquímicas y fisiológicas de $R$. solanacearum

Tabla 11 Incidencia de la enfermedad, expresada en porcentaje de plantas mostrando resultado positivo por DAS-ELISA a la presencia de C.m.michiganensis tras las semanas de tratamiento a $25^{\circ} \mathrm{C}$

Tabla 12 Resultados obtenidos del análisis de la varianza de los valores medios de la incidencia de la enfermedad para los factores dosis de material infectado, semanas de duración del tratamiento térmico y tipo de macetas (abiertas o cerradas), así como para sus interacciones, para los tratamientos a $25^{\circ} \mathrm{C}$.

Tabla 13 Resultados obtenidos mediante la realización de la prueba de Fisher (LSD con $\mathrm{P}<0,05$ ) para los diferentes factores considerados en los tratamientos a $25^{\circ} \mathrm{C}$ : dosis, tipo de macetas ( $\mathrm{NB}=$ sin bolsa, $\mathrm{B}=$ con bolsa) y semanas de tratamiento, transcurridos 40 días tras el trasplante. Las medias representan la incidencia de la enfermedad según el porcentaje de plantas afectadas por C.m.michiganensis.

Tabla 14 Incidencia de la enfermedad, expresada en porcentaje de plantas mostrando resultado positivo por DAS-ELISA a la presencia de C.m.michiganensis tras las semanas de tratamiento a $45^{\circ} \mathrm{C}$ 
Tabla 15 Resultados obtenidos del análisis de la varianza de los valores medios de la incidencia de la enfermedad para los factores dosis de material infectado, semanas de duración del tratamiento térmico y tipo de macetas, así como para sus interacciones

Tabla 16 Resultados obtenidos mediante la realización de la prueba de Fisher (LSD con $\mathrm{P}<0,05$ ) para los diferentes factores considerados en los tratamientos a $45^{\circ} \mathrm{C}$ : dosis, tipo de macetas ( $\mathrm{NB}=$ sin bolsa, $\mathrm{B}=$ con bolsa) y semanas de tratamiento, transcurridos 40 días tras el trasplante. Las medias representan la incidencia de la enfermedad según el porcentaje de plantas afectadas por C.m.michiganensis

Tabla 17 Promedio del conteo de colonias de C.m.michiganensis procedentes del substrato tratado tras un periodo de 6 semanas a $25^{\circ} \mathrm{C}$

Tabla 18 Incidencia de la enfermedad, expresada en porcentaje de plantas mostrando resultado positivo por DAS-ELISA a la presencia de $R$. solanacearum tras las semanas de tratamiento a $25^{\circ} \mathrm{C}$

Tabla 19 Resultados obtenidos del análisis de la varianza de los valores medios de la incidencia de la enfermedad para los factores dosis de material infectado, semanas de duración del tratamiento térmico y tipo de macetas (abiertas o cerradas), así como para sus interacciones, para los tratamientos a $25{ }^{\circ} \mathrm{C}$ contra $R$. solanacearum

Tabla 20 Resultados obtenidos mediante la realización de la prueba de Fisher (LSD con $\mathrm{P}<0,05)$ para los diferentes factores considerados en los tratamientos a $25^{\circ} \mathrm{C}$ : dosis, tipo de macetas $(\mathrm{NB}=\sin$ bolsa, $\mathrm{B}=$ con bolsa) y semanas de tratamiento, transcurridos 40 días tras el trasplante. Las medias representan la incidencia de la enfermedad según el porcentaje de plantas afectadas por $R$. solanacearum

Tabla 21 Promedio del conteo de colonias de $R$. solanacearum en el substrato tras un periodo de 6 semanas a $25^{\circ} \mathrm{C}$

Tabla 22 Diferencia de superficie dañada $\left(\mathrm{mm}^{2}\right)$ en las hojas transcurrido un mes desde los diferentes tratamientos (T1)

Tabla 23 Comparación de esporulación entre lesiones de hojas procedentes de distintas localidades

Tabla 24 Diferencia de ascosporas $(\log (\mathrm{x}+1)$ donde $\mathrm{x}$ es el número de esporas por $\mathrm{mm}^{2}$ ) en las muestras sometidas a distintos tratamientos

Tabla 25 Diferencia en la cuantificación de ADN de M. brassicicola para los diferentes tratamientos para $\mathrm{T} 1$

Tabla 26 Ascosporas y cuantificación de ADN en las diferentes posiciones de los packs 


\section{ÍNDICE DE FIGURAS}

Fig. 1 (A) Solarización. (B) Quema de restos en campos de chufa (Cyperus sculentum) (B) localizados ambos en la provincia de Valencia

Fig. 2 Cromatografía de gases de aceites esenciales en hojas de tomate

Distribución mundial de Ralstonia solanacearum

Fig. 4 Distribución mundial de Clavibacter michiganensis subs. michiganensis

Fig. 5 Método de las diluciones seriadas

Fig. 6 Preparación de los lotes de macetas para ser sometidas a los tratamientos térmicos

Fig. 7a Esquema de la introducción y recuperación semanal de cepas bacterianas en substratos infectados artificialmente

Fig. $7 b$ Esquema de la supervivencia de los patógenos en asociación con tejidos vegetales

Fig. 8 Mapa de Holanda

Fig. 9 Parrillas preparadas con 4 hojas y "pack" de 7 hojas

Fig. 10 Esquema de tratamiento en campo

Fig.11 Aspecto de las colonias de C.m.michiganensis en D2

Fig. 12 Avance de la respuesta hipersensible de C.m.michiganensis en plantas de tabaco, en las condiciones de ensayo en invernadero. A: avance de síntomas transcurrido 1 día desde la inoculación. B: estado de la zona infiltrada transcurridos 4 días desde la inoculación

Fig. 13 Plantas de tomate con síntomas de chancros observados tras la inoculación de C.m.michiganensis

Fig. 14 Imágenes observadas por microscopía electrónica de barrido de una sección transversal de un tallo infectado de tomate (Lycopersicon esculentum) colapsado por masas bacterianas. A: Masas bacterianas emanando desde los vasos conductores obstruidos B: Bacterias bloqueando los vasos xilemáticos

Fig. 15 Diferencia de crecimiento observada entre plantas del lote 0 (sin ningún tipo de tratamiento térmico) crecidas sobre substrato conteniendo restos de tomate sanos y plantas sobre substrato con restos de tomate infectados

Fig. 16 Comparación de raíces de plantas de tomate crecidas sobre substratos conteniendo distintas dosis de restos de tomate infectados con C.m.michiganensis y detalle de daños ocasionados en raíces de plantas crecidas sobre substratos con $15 \mathrm{~g}$ de material infectado en comparación con raíces de plantas totalmente sanas 
Fig. 17 Comparación de daños observados en raíces de plantas de tomate dependiendo de la forma de penetración del patógeno, de izquierda a derecha: por contacto directo con substrato infectado o por inoculación infiltrando las axilas de las hojas y con una raíz de planta sana

Fig. 18 Efecto de los tratamientos a $25{ }^{\circ} \mathrm{C}$ en la incidencia final de la enfermedad, expresada como porcentaje de plantas de tomate infectadas por C.m.michiganensis en macetas encerradas en bolsas de plástico (B) y en macetas sin bolsa (NB) a los 40 días del trasplante. Los histogramas representan el porcentaje de infección obtenido en cuatro repeticiones por tratamiento y dosis de material vegetal infectado e incorporado

Fig. 19 Efecto de los tratamientos a $45{ }^{\circ} \mathrm{C}$ en la incidencia final de la enfermedad, expresada como porcentaje de plantas de tomate infectadas por C.m.michiganensis en macetas encerradas en bolsas de plástico (B) y en macetas sin bolsa (NB) a los 40 días del trasplante. Los histogramas representan el porcentaje de infección obtenido en cuatro repeticiones por tratamiento y dosis de material vegetal infectado e incorporado

Fig. 20 Rhizopus creciendo en placa de YDA sembrada con $100 \mu$ de la dilución $10^{5}$ del substrato tratado durante 4 semanas a $45^{\circ} \mathrm{C}$

Fig. 21 Crecimiento de colonias bacterianas diferentes a C.m.michiganensis en los medios de crecimiento tras los tratamientos térmicos a $25^{\circ} \mathrm{C}$ y $45^{\circ} \mathrm{C}$

Fig. 22 Efecto del tratamiento térmico a $25^{\circ} \mathrm{C}$ en la dinámica poblacional
de C.m.michiganensis y otras colonias de bacterias en los medios

Fig. 22 Efecto del tratamiento térmico a $25^{\circ} \mathrm{C}$ en la dinámica poblacional
de C.m.michiganensis y otras colonias de bacterias en los medios nutritivos ensayados (YDA y D2)

Fig. 23 Reacción de antibiosis observada bajo lupa y SEM en placas de YDA. La bacteria responsable de la inhibición de crecimiento (A) se identificó como Bacillus subtilis (A: Bacillus subtilis; B: zona de inhibición de crecimiento) y zona de inhibición observada por SEM (C: colonia bacteriana; D: zona de inhibición causada por Bacillus subtilis)

Fig. 24 Antagonismo in Vitro entre Bacillus subtilis y C.m.michiganensis. B. subtillis se aplicó en la placa de $\mathrm{KB}$ a partir de una gota de $5 \mu 1$ de una suspensión del cultivo puro $\left(10^{7} \mathrm{cfu} \mathrm{ml}^{-1}\right)$. Tras $48 \mathrm{~h}$ de crecimiento a $28{ }^{\circ} \mathrm{C}$ una suspensión de C.m.michiganensis $\left(10^{7} \mathrm{cfu}\right.$ $\mathrm{ml}^{-1}$ ) fue pulverizada sobre las placas. Tras $24 \mathrm{~h}$ se observaba la reacción

Fig. 25 Aspecto de las colonias de $R$. solanacearum observadas en YDA (A y B) y en TTC (C y D) 
Fig. 26 Avance de la respuesta hipersensible de $R$. solanacearum en plantas de tabaco, en las condiciones de ensayo. A: avance de síntomas transcurrido 1 día desde la inoculación. B: estado de la zona infiltrada transcurridos 4 días desde la inoculación

Fig. 27 Plantas de tomate con síntomas observados tras la inoculación de R. solanacearum

Fig. 28 Imágenes observadas por microscopía electrónica de barrido de una sección transversal de un tallo infectado de tomate inoculado con $R$. solanacearum. A: se observan vasos obstruidos B: se observan vasos obstruidos y desprendimiento de tejido en la parte inferior derecha debido a la degradación de los tejidos.

Fig. 29 Efecto de los tratamientos a $25{ }^{\circ} \mathrm{C}$ en la incidencia final de la enfermedad, expresada como porcentaje de plantas de tomate infectadas por $R$. solanacearum en macetas sin bolsa (NB) y en macetas encerradas en bolsas de plástico (B) a los 40 días del trasplante

Fig. 30 Efecto de los tratamientos a $45{ }^{\circ} \mathrm{C}$ en la incidencia final de la enfermedad, expresada como porcentaje de plantas de tomate infectadas por $R$. solanacearum en macetas encerradas en bolsas de plástico (B) y en macetas sin bolsa (NB) a los 40 días del trasplante

Fig. 31 Crecimiento de colonias bacterianas diferentes a $R$. solanacearum
en los medios de crecimiento tras los tratamientos térmicos a $25^{\circ} \mathrm{C}$

Fig. 31 Crecimiento de colonias bacterianas diferentes a $R$. solanacearum
en los medios de crecimiento tras los tratamientos térmicos a $25^{\circ} \mathrm{C}$ y $45{ }^{\circ} \mathrm{C}$

Fig. 32 Efecto del tratamiento térmico a $25{ }^{\circ} \mathrm{C}$ en la dinámica poblacional de $R$. solanacearum y del resto de colonias de bacterias observadas en los medios nutritivos ensayados (YDA y TTC)

Fig. 33 Esporas de M. brassicicola observadas en el microscopio óptico

Fig. 34 Lesiones de mancha en anillo, causadas por M. brassicicola, observadas en hojas procedentes de las localidades A (campo biológico) y B (campo tradicional)

Fig. 35 Estimación de la superficie dañada por localidad. Los valores para T0 (sin ningún tratamiento) y para T1 (diferentes tratamientos y control) se muestran juntos

Fig. 36 Resultados de la cuantificación de ADN de M. brassicicola (fg $\mathrm{ADN} \mathrm{mg}{ }^{-1}$ de peso seco) por localidad. Los valores para T0 ( $\mathrm{sin}$ ningún tipo de tratamiento) y para $\mathrm{T} 1$ (diferentes tratamientos $\mathrm{y}$ control) se muestran conjuntamente

Fig. 37 Relación entre las cantidades de $\mathrm{ADN}\left(\mathrm{fg} \mathrm{mg}^{-1}\right.$ ) y la superficie dañada en las hojas afectadas $\left(\mathrm{mm}^{2}\right)$

Fig. 38 Porcentaje de descomposición de las hojas tras un mes de la aplicación de los tratamientos 


\section{ABREVIATURAS}

\begin{tabular}{|c|c|}
\hline BM & Bromuro de metilo \\
\hline $\mathrm{cc}$ & Centímetros cúbicos \\
\hline $\mathrm{cm}$ & Centímetro \\
\hline $\mathrm{d}$ & Día \\
\hline DAS-ELISA & $\begin{array}{l}\text { Double Antiserum Sándwich- Enzyme Linked Immunosorbent } \\
\text { Assay }\end{array}$ \\
\hline ELISA & Enzyme Linked Immunosorbent Assay \\
\hline EPS & Exapolisacáridos o Polisacáridos extracelulares \\
\hline $\mathrm{g}$ & Gramo \\
\hline $\mathrm{h}$ & Hora \\
\hline ha & Hectárea \\
\hline HR & Respuesta hipersensible \\
\hline $\mathrm{IM}$ & Ioduro de metilo \\
\hline IPM & Integrated Pest Management \\
\hline $\mathrm{kg}$ & Kilogramo \\
\hline LSD & Least Significant Difference \\
\hline $\mathrm{m}$ & Metro \\
\hline MBTOC & Methyl Bromide Technical Option Committee \\
\hline $\mathrm{ml}$ & Mililitro \\
\hline $\min$ & Minuto \\
\hline $\mathrm{mm}$ & Milimetros \\
\hline $\mathrm{nm}$ & Nanometro \\
\hline OEPP/EPPO & European and Mediterranean Plant Protection Organization \\
\hline PCR & Reacción en cadena de la polimerasa \\
\hline $\mathrm{PE}$ & Polietileno \\
\hline PIC & Cloropicrina \\
\hline PM & Protocolo de Montreal \\
\hline $\operatorname{tn}$ & Tonelada \\
\hline TSA & Trypticase Soy Agar \\
\hline TTC & Cloruro de Trifenil Tetrazolio \\
\hline $\mathrm{UFC} / \mathrm{cfu}$ & Unidades formadoras de colonias \\
\hline VBNC & Viable no cultivable \\
\hline VIF & Film Virtualmente Impermeable \\
\hline $\mathrm{v} / \mathrm{v}$ & Relación volumen volumen \\
\hline YDA & Yeast Dextrose Agar \\
\hline${ }^{\circ} \mathrm{C}$ & Grados centígrados \\
\hline $1,3-\mathrm{D}$ & 1,3-Dicloropropeno \\
\hline$\mu l$ & Microlitro \\
\hline$\mu \mathrm{m}$ & Micras \\
\hline
\end{tabular}




\section{RESUMEN}

La producción de muchos cultivos ha dependido del empleo del bromuro de metilo como fumigante para controlar un gran número de patógenos transmitidos por el suelo, pero este producto fue prohibido en 2005. Esta situación ha implicado un incremento en el interés por desarrollar otras estrategias alternativas para controlar los patógenos del suelo.

Entre las alternativas no químicas para reducir el consumo de bromuro de metilo destacan la biofumigación y la solarización. La biofumigación es una importante técnica de control biológico que emplea el efecto de las sustancias volátiles que se liberan durante la descomposición de la materia orgánica $y$, mediante la incorporación de restos vegetales en el suelo, mejora el rendimiento. Además, los restos de cultivo pueden eliminarse disminuyendo su impacto ambiental. Pero el principal problema de incorporar residuos vegetales en el suelo es su riesgo potencial como foco de enfermedades.

La biofumigación ha sido evaluada, bajo condiciones controladas, para el control de las bacterias patógenas Clavibacter michiganensis y Ralstonia solanacearum. El sustrato experimental (mezcla de turba y arena) fue infectado de forma artificial con las bacterias patógenas usando restos frescos de tomate. Se ensayó el efecto de tres dosis diferentes de material vegetal infectado artificialmente $(5,10$ y $15 \mathrm{~g})$ en $500 \mathrm{~g}$ de sustrato durante 6 semanas a $25{ }^{\circ} \mathrm{C}$ (considerado como biofumigacón) y a $45^{\circ} \mathrm{C}$ (considerado como biofumigación con solarización o biosolarización).

La incidencia de la enfermedad no disminuyó con la biofumigación, pero el tratamiento de biosolarización controló ambas bacterias. Debido a este resultado, la biofumigación con solarización muestra una gran eficiencia para emplearse como técnica fumigante del suelo para el manejo de bacterias fitopatógenas.

En el segundo experimento, la supervivencia de las bacterias patógenas, tanto en sustratos como en las plantas infectadas de forma artificial se estudió para determinar el comportamiento de los patógenos bajo las condiciones 
experimentales. Se identificaron distintas cepas de bacterias saprofitas de los géneros Bacillus, Paenibacillus y Brevibacillus y se observaron reacciones de antagonismo in Vitro entre Bacillus subtilis y C.m.michiganensis.

Finalmente, se estudió el efecto de diferentes tratamientos en restos de coles de Bruselas para controlar la enfermedad de mancha en anillo causada por Mycosphaerella brassicicola. Esta investigación se llevó a cabo bajo condiciones de campo con el objetivo de prevenir la diseminación fúngica. Los tratamientos incluyeron el uso de productos biológicos, que aceleran la descomposición de las hojas, y de antagonistas fúngicos. Estos tratamientos biológicos se compararon con el efecto de la urea como producto químico. También se compararon la esporulación de M. brassicicola y su cantidad de ADN en muestras de hojas que fueron tratadas. Los resultados mostraron la aplicación de urea como el mejor tratamiento contra la esporulación de M. brassicicola en las lesiones tratadas. 


\section{ABSTRACT}

The production of several vegetable crops has depended on the use of methyl bromide soil fumigation to control a wide array of soil-borne pathogens, but this product was banned from 2005. This situation has led to increase interest in the development of alternative strategies to control soil-borne pathogens.

Among the non-chemical alternatives to reduce the consumption of methyl bromide biofumigation and solarization are outstanding. Biofumigation is an important biological control technique that uses the effect of volatile substances that are released during the decomposition of organic matter and by incorporation of vegetal debris in the soil improves the yield. In addition, crop residues can be eliminated decreasing their environmental impact. But the main problem with the incorporation of vegetal debris in the soil is the potential risk that these residues have as diseases source.

Biofumigation was evaluated under controlled conditions for control of the pathogenic bacteria Clavibacter michiganensis and Ralstonia solanacearum. The experimental substrate (peat moss and sand mix) was artificially infested with the bacterial pathogen using fresh tomato debris. The effect of three different doses of artificially infected plant material $(5,10$ and $15 \mathrm{~g})$ in $500 \mathrm{~g}$ of substrate was tested during 6 weeks at $25^{\circ} \mathrm{C}$ (considered as biofumigation) and at $45^{\circ} \mathrm{C}$ (considered as biofumigation with solarization or biosolarization).

Disease incidence had not decreased using biofumigation and biosolarization treatment controlled both bacteria. Because of this result, biofumigation with solarization shows potential to be used as a soil biofumigant technique for the management of phytopathogenic bacteria.

In the second experiment, the survival of the pathogenic bacteria in either artificially infested substrate or in artificially infected tomato plants was studied to determine the behaviour of the pathogens under the experimental conditions. Strains of saprophytic bacteria in the genera Bacillus, Paenibacillus and 
Brevibacillus were identified and in vitro antagonism between Bacillus subtilis and C.m.michiganensis was observed.

Finally, the effect of different treatments on Brussels sprouts debris was studied to control the ring spot disease caused by Mycosphaerella brassicicola. This research was carried out under field conditions in order to prevent the fungal dissemination. Treatments included the use of biological products that accelerates leaf decomposition and fungal antagonists. These biological treatments were compared with the effect of urea as chemical product. The sporulation of $M$. brassicicola and its amounts of DNA in samples of treated leaves was assessed. Results showed the application of urea as the best treatment against the sporulation of $M$. brassicicola in the treated lesions. 


\section{RESUM}

La producció de molts cultius ha depès de l'ocupació del bromur de metilo com fumigant per a controlar un gran nombre de patògens transmesos pel sòl, però aquest producte va ser prohibit en 2005. Aquesta situació ha implicat un increment en l'interès per desenvolupar altres estratègies alternatives per a controlar els patògens del sòl.

Entre les alternatives no químiques per a reduir el consum de bromur de metilo destaquen la biofumigació i la solarizatció. La biofumigació és una important tècnica de control biològic que aprofita l'efecte de les substàncies volàtils que s'alliberen durant la descomposició de la matèria orgànica i, mitjançant la incorporació de restes vegetals en el sòl, millora el rendiment. A més, les restes de cultiu poden eliminar-se disminuint el seu impacte ambiental. Però el principal problema d'incorporar residus vegetals en el sòl és el seu risc potencial com focus de malalties.

La biofumigació ha estat avaluada, baix condicions controlades, per al control dels bacteris patògens Clavibacter michiganensis i Ralstonia solanacearum. El substrat experimental (barreja de torba i arena) va ser infectat de forma artificial amb els bacteris patògens usant restes fresques de tomaca. Es va assajar l'efecte de tres dosi diferents de material vegetal infectat artificialment (5, $10 \mathrm{i} 15 \mathrm{~g}$ ) en $500 \mathrm{~g}$ de substrat durant 6 setmanes a $25^{\circ} \mathrm{C}$ (considerat com biofumigació) i a $45{ }^{\circ} \mathrm{C}$ (considerat com biofumigació amb solarizatció o biosolarizatció).

La incidència de la malaltia no va disminuir amb la biofumigació, però el tractament de biosolarizatció va controlar ambdós bacteris. A causa de aquest resultat, la biofumigació amb solarizatció mostra una gran eficiència per a usar-se com tècnica fumigant del sòl per al maneig de bacteris fitopatógens.

En el segon experiment, la supervivència dels bacteris patògens, tant en substrats com en les plantes infectats de forma artificial es va estudiar per a determinar el comportament dels patògens baix les condicions experimentals. Es 
van identificar diferents ceps de bacteris saprofits dels gèneres Bacillus, Paenibacillus i Brevibacillus i es van observar reaccions de antagonisme in Vitro entre Bacillus subtilis i C.m.michiganensis.

Finalment, es va estudiar l'efecte de diferents tractaments en restes de cols de Brusselles per a controlar la malaltia de taca en anell causada per Mycosphaerella brassicicola. Aquesta investigació es va portar a terme baix condicions de camp amb l'objectiu de prevenir la disseminació fúngica. Els tractaments van incloure l'ús de productes biològics, que acceleren la descomposició de les fulles, i de antagonistes fúngics. Aquests tractaments biològics es van comparar amb l'efecte de la urea com producte químic. També es van comparar la esporulació de M. brassicicola i la seva quantitat de ADN en mostres de fulles que van ser tractades. Els resultats van mostrar l'aplicació de urea com el millor tractament contra la esporulació de M. brassicicola en les lesions tractades 


\section{INTRODUCCIÓN}

\section{Desinfección de los suelos y sustratos: control de patógenos}

La desinfección de suelos se considera una intervención en los sistemas de cultivo siendo el principal objetivo en cualquier tipo de intervención sobre los sistemas agrarios la mejora de calidad de los productos obtenidos.

En referencia a la importancia del suelo en dichos sistemas de cultivo, se busca la optimización de su manejo, reduciendo el impacto ambiental de las prácticas agrícolas y estando relacionada esta reducción tanto con una disminución en la contaminación provocada por el uso de agroquímicos, como con una buena gestión de los residuos agrarios.

Los patógenos del suelo son los causantes de las mayores pérdidas ocasionadas en algunos cultivos de gran importancia económica en el sur de Europa y, por esta razón, la desinfección en horticultura intensiva representa una práctica crucial para combatir no sólo los patógenos de las plantas sino también malas hierbas y plagas de artrópodos permitiendo mantener los altos niveles de productividad (Gullino, 2000). En España, las técnicas de desinfección de suelos adquieren una gran importancia en relación a la gran superficie de cultivos bajo invernadero (Tello, 1998) ya que el control de los patógenos telúricos, en el caso de los sistemas de producción intensiva, es una tarea complicada porque aunque entre las distintas estrategias de control se encuentran las de rotación y el uso de variedades resistentes, ambas son de difícil aplicación debido a la propia intensidad de cultivos así como a la falta de cultivares resistentes a varios patógenos (Diánez, 2005).

En general, las prácticas hortícolas actuales inducen a la repetición de cultivos, o grupos de cultivos, en la misma parcela o bajo invernadero sin haber dejado un tiempo de descanso, por lo que resulta bastante frecuente que se presenten problemas de acumulación excesiva de parásitos en el suelo que también hace peligrar la viabilidad de los cultivos que, como consecuencia, pueden 
presentar un crecimiento anormalmente lento asociado a una disminución general de vigor. Así, cuando se desinfectan suelos y sustratos se pretende lograr el control de las poblaciones de microorganismos patógenos que habitan en ellos y que pueden afectar al buen desarrollo de los cultivos mermando su rendimiento.

Con todo ello, la desinfección de suelos y sustratos permanece como una práctica esencial en la horticultura intensiva moderna para resolver los problemas asociados tanto a la presencia de patógenos como a fenómenos de fatiga de suelos y sustratos (Maroto, 1990; Gullino, 2000; Diánez, 2005).

\subsection{Utilización óptima de los métodos más comunes de desinfección de suelos}

La desinfección de suelos y sustratos puede lograrse mediante la aplicación de diferentes técnicas debiendo realizar la elección de los métodos de desinfección de acuerdo con las condiciones de cada sistema de cultivo. En función a su actividad, los diferentes tratamientos desinfectantes pueden tener una acción biocida total o resultar biostáticos y tener poca actividad bactericida.

Las técnicas de desinfección de suelos se pueden clasificar como químicas o no químicas existiendo la posibilidad de combinarlas con la finalidad de aprovechar y mejorar al máximo los efectos beneficiosos que estas ofrecen y, en algunas ocasiones, la combinación de técnicas químicas con otros métodos de control garantiza un buen resultado (Rodríguez-Kábana, 1998). Entre las técnicas empleadas, la desinfección con fumigantes químicos y el uso de calor tanto seco como húmedo, incluyendo el aprovechamiento de la radiación solar o las desinfecciones con vapor de agua, son las prácticas de control más difundidas tanto en los cultivos hortícolas como ornamentales (Diánez, 2005). No obstante, lo más frecuente es recurrir al uso de productos químicos debido, principalmente, a sus sencillez de aplicación (Barres, 2006).

La elección del método de desinfección adquiere importancia a la hora de catalogar la producción agrícola, como ecológica o tradicional, o debido a las actuales normativas de certificación. Como ejemplos, actualmente existen 
normativas de certificación que incorporan la necesidad de implantación de metodologías que garanticen la calidad medioambiental de los productos agrarios evaluando una serie de parámetros entre los que se encuentran el uso de productos fitosanitarios o el tratamiento de residuos agrícolas, endureciendo la metodología de manipulación de productos químicos. Entre estas normativas encontramos la certificación MPS (Sistema de Calidad Medioambiental para flores y plantas) que afecta, principalmente, a viveristas y cultivadores de cultivos ornamentales (MPS, 2005). Así, en la metodología seleccionada para la obligatoria desinfección de suelos y sustratos donde crecen las plantas madre, se penaliza el uso de productos químicos favoreciendo el uso de técnicas menos nocivas.

Por otra parte, en la búsqueda actual de soluciones para cualquier plaga, enfermedad o malas hierbas, se tiende a que estas soluciones estén "idealmente" fundamentadas en el concepto de IPM, del inglés "Integrated Pest Management" que se traduce como Manejo Integrado de Plagas, siendo su principal objetivo la minimización del empleo de biocidas de amplio espectro para evitar o reducir los problemas como la contaminación medioambiental, la eliminación de enemigos naturales y la inducción de resistencias. Este objetivo se alcanza evitando la aplicación profiláctica o programada de dichos agentes biocidas de modo que cualquier aplicación debería ser necesaria y estar dirigida contra patógenos específicos (Matthiessen y Kirkegaard, 2006). El impedimento práctico más significativo en la implementación del manejo integrado de organismos presentes en el suelo, se debe principalmente al trastorno físico que supone colocar el agente de control en el suelo en el lugar afectado por la plaga o enfermedad, efecto exacerbado por la frecuente naturaleza fitotóxica de los agentes de control de amplio espectro.

No obstante, la metodología más empleada por factible y efectiva para el manejo de los organismos del suelo es la aplicación de un método de control (químico, o no) como medida profiláctica antes de la siembra del cultivo. Estos métodos suelen emplear agentes de amplio espectro para eliminar el mayor rango 
posible de amenazas latentes o procedentes de fuentes externas. La elección de cada estrategia de manejo dependerá también de la conveniencia en cada sistema de producción; por ejemplo, las adecuadas para los sistemas de cultivo extensivos con rotaciones discontinuas serán diferentes al del caso extremo de los sistemas de cultivo intensivos, con cultivos de alto valor y con frecuencia de producción casi continua que se interrumpe sólo durante el tiempo suficiente para esterilizar el suelo. En ambos casos, el producto empleado mayoritariamente ha sido el bromuro de metilo $(\mathrm{BM})$ o metilbromuro $\left(\mathrm{CH}_{3} \mathrm{Br}\right)$ teniendo que esperar hasta su disipación antes de plantar el cultivo siguiente.

\subsection{Problemática del $B M$}

Desde hace tiempo, el empleo de fumigantes se ha considerado potencialmente dañino para el medio ambiente y como consecuencia se han impuesto muchas restricciones para la regulación o reducción de su uso. Un gran número de los fumigantes actualmente disponibles están estrictamente regulados y, de hecho, algunos de los más efectivos han quedado totalmente prohibidos debido a su daño medioambiental (Gullino et al., 2003).

El BM ha sido ampliamente utilizado en el mundo abarcando múltiples usos que incluyen la fumigación de suelos, fumigación de grano almacenado, tratamientos de control de cuarentenas tanto de exportación e importación y la fumigación de estructuras, conocida como "fumigación estructural" (Ohr et al., 1996). Pero los escapes de metilbromuro a la atmósfera tras su aplicación son importantes. Estos últimos autores confirman que de la cantidad total de producto aplicado al suelo aproximadamente un $87 \%$ se pierde en la atmósfera en tan sólo 7 días y, al alcanzar la estratosfera, sufre una foto-oxidación, liberando átomos de bromo que son responsables de la reducción total de ozono. Debido a este efecto, en la IV reunión del protocolo de Montreal (PM) celebrada en Copenhague en noviembre de 1992 se planteó la retirada del producto creándose un comité de expertos cuyo objetivo sería el de encontrar alternativas. Este comité es conocido 
como MBTOC ("Methyl Bromide Technical Option Committee"). Además otro comité sería el encargado de la evaluación económica (TEAP "Technology and Economic Assesment Panel) (Tello y Bello, 2002). En diciembre de 1995, en la VII reunión de Viena se estableció un primer calendario que prohibía el uso de BM en el año 2010, en el caso de los países desarrollados. Pero, el 17 de septiembre de 1997 el PM reunido esta vez en Montreal tomó la decisión de establecer un nuevo calendario para la eliminación del BM quedando el año 2005 como nueva fecha máxima de uso, exceptuando los denominados "usos críticos" o esenciales. El calendario definitivo para la eliminación del uso de BM como fumigante de suelos se muestra en la tabla 1 (Cebolla, 1998; López y Guirao, 1998)

Tabla 1. Calendario para la eliminación del uso de bromuro de metilo como fumigante de suelos acordado en septiembre de 1997 (fuente: Cebolla, 1998)

\begin{tabular}{|c|c|c|}
\hline & Para los países desarrollados & Países en vías de desarrollo \\
\hline \multicolumn{3}{|c|}{$\%$ de reducción tomando como base el } \\
\hline Año & consumo 1991 & Consumo medio 1995-1998 \\
\hline 1997 & congelación & \\
\hline 1999 & $25^{*}$ & \\
\hline 2001 & 50 & \\
\hline 2002 & & congelación \\
\hline 2003 & 70 & \\
\hline 2005 & 100 & 20 \\
\hline 2015 & & 100 \\
\hline
\end{tabular}

*Para la Unión Europea esta reducción se adelantó al año 1998

Observando el calendario anterior cabe indicar la excepción anteriormente mencionada de "usos críticos", así como para cuarentenas y productos de exportación. Acerca de los "usos críticos" según la información aportada por Bello y Tello (1998) consultando la decisión IV/25 del PM, los criterios para determinar tales usos son: 
- El uso de una sustancia regulada será esencial sólo si:

- Es necesario para la salud o la seguridad o si es imprescindible para el funcionamiento de la sociedad (incluidos los aspectos culturales e intelectuales)

- No hay sustitutos ni alternativas técnicas y económicamente viables y aceptables desde el punto de vista del medio ambiente y la salud

- la producción y el consumo de una sustancia regulada para usos esenciales podrá autorizarse solamente si:

- se han tomado todas las medidas viables económicamente para reducir al mínimo el uso esencial y la correspondiente emisión de la sustancia regulada

- no se dispone de la sustancia regulada en cantidad y calidad suficiente en las reservas existentes, sin olvidarse de la necesidad de sustancias reguladas de los países en desarrollo

Estos mismos autores ya indicaron en 1998 que en España, atendiendo a los conocimientos científicos y técnicos, los "usos críticos" corresponderían únicamente a los cultivos de pimientos y fresas.

De la evolución en el empleo de BM, entre los años 1995 y 2005, se observa una drástica disminución según cultivos, de hecho en 2005 se concede permiso de aplicación para los "usos críticos" refiriéndose estos únicamente a 4 cultivos (tablas 2 y 3). Ya en 2008 en el Diario Oficial de la Unión Europea se publica la decisión de la comisión de 25 de marzo de 2008 por la que se determinan las cantidades de bromuro de metilo que se podrán utilizar en la Comunidad desde el 1 de enero hasta 31 de diciembre de 2008 de conformidad con el reglamento (CE) $n^{\circ}$ 2037/2000 sobre las sustancias que agotan la capa de ozono. En el artículo 1 "se autoriza al Reino de España y a la República de Polonia a utilizar un total de $212671 \mathrm{~kg}$ de bromuro de metilo para usos críticos”. Estas cantidades, con respecto 
a España, quedan desglosadas en las cantidades y categorías recogidas en la tabla 4.

Tabla 2. Cultivos con mayor consumo de BM en España en el año 1995 (Fuente: Bello y Tello, 1998)

\begin{tabular}{|c|c|c|}
\hline Cultivo & Provincia & $\mathbf{B M}(\mathbf{t})$ \\
\hline Papa & Valencia $^{1}$ & $328^{2}$ \\
\hline \multirow[t]{3}{*}{ Tomate } & Alicante $^{1}$ & 110 \\
\hline & Almería $^{1}$ & 1022 \\
\hline & Murcia $^{1}$ & 26 \\
\hline Judías & Almería $^{1}$ & Ver tomate \\
\hline \multirow[t]{2}{*}{ Sandía } & Almería $^{1}$ & 1732 \\
\hline & Valencia $^{1}$ & Ver papa \\
\hline Calabacín & Almería $^{1}$ & Ver sandía \\
\hline Melón & Almería $^{1}$ & Ver sandía \\
\hline Pepino & Almería $^{1}$ & Ver sandía \\
\hline Zanahoria & Cádiz $^{1}$ & 21 \\
\hline \multirow[t]{3}{*}{ Hortalizas en general } & Barcelona $^{1}$ & 39 \\
\hline & Valencia $^{1}$ & 75 \\
\hline & Cádiz & 122 \\
\hline \multirow[t]{3}{*}{ Ornamentales } & Barcelona $^{1}$ & 39 \\
\hline & Cádiz $^{1}$ & 321 \\
\hline & Sevilla $^{1}$ & 31 \\
\hline \multirow[t]{2}{*}{ Fresas y fresón } & Barcelona $^{1}$ & 52 \\
\hline & Huelva $^{1}$ & 897 \\
\hline \multirow[t]{3}{*}{ Pimiento } & Alicante & 305 \\
\hline & Almería $^{1}$ & 203 \\
\hline & Murcia & 668 \\
\hline
\end{tabular}




\begin{tabular}{ccc}
\hline Cultivo & Provincia & BM(t) \\
\hline Viveros fresas & Segovia & 157 \\
& Ávila & 101 \\
& Navarra & 90 \\
& Palencia & 33 \\
& Huelva & 27 \\
\hline Cítricos $^{3}$ & & 78 \\
\hline Canarias $^{4}$ & & 79 \\
\hline
\end{tabular}

${ }^{1}$ Sólo se usaba BM con una frecuencia bianual; ${ }^{2}$ Este cultivo forma parte de un sistema de rotación con otros 2,3 ó mas cultivos; ${ }^{3}$ el BM se utiliza cada 30 años y está prohibido en producción integrada y ecológica; ${ }^{4}$ Canarias no especificó el tipo de cultivo

Tabla 3. BM concedido como usos críticos para España en el año 2005 (Fuente: Bello y Díez Rojo, 2004)

\begin{tabular}{ccc} 
Cultivo & Lugar & BM(t) \\
\hline Fresa & Huelva & 556 \\
\hline Fresa viveros & Castilla y León & 230 \\
\hline Pimiento & Alicante y Murcia & 200 \\
\hline Flor cortada & Cádiz y Sevilla & 53 \\
& Cataluña & 20 \\
\hline
\end{tabular}


Tabla 4. BM concedido como usos críticos para España en el año 2008 (Fuente: Comisión Europea, 2008)

\begin{tabular}{rc} 
Categorías de usos críticos autorizados & $\mathbf{k g}^{\mathbf{1}}$ \\
\hline Estolones de fresa (cultivados a gran altura) & 200000 \\
\hline Flores de corte (investigación únicamente) & 25 \\
\hline Fresa y pimiento (investigación únicamente) & 151 \\
\hline Total & 200176
\end{tabular}

${ }^{1}$ Existencias de BM disponibles para usos críticos en el Estado miembro $6288,12 \mathrm{~kg}$

En los últimos años, y de acuerdo con todo lo anterior (respecto a la prohibición del BM para su uso en la desinfección del suelo) se ha acentuado la necesidad de estrategias alternativas para el manejo de enfermedades y plagas del suelo, y no sólo para los consumidores de BM, sino en un sentido general (Matthiessen y Kirkegaard, 2006).

\subsection{Alternativas al BM}

El MBOTC define una "alternativa" como aquellos tratamientos o procedimientos químicos y no químicos que son técnicamente viables para el control de organismos patógenos permitiendo la eliminación del BM y establece diferencias entre las consideradas "alternativas existentes" y "alternativas potenciales". Las primeras se corresponden con las que se están aplicando o se han aplicado en alguna región concreta mientras que las últimas están en proceso de investigación o desarrollo (Bello y Díez Rojo, 2004). Estas alternativas, a su vez, se clasifican en tres grupos (tabla 5): alternativas no químicas, alternativas químicas y alternativas de control integrado (Rodríguez-Kábana, 1998; Tello y Bello, 2002). 
Tabla 5. Alternativas al bromuro de metilo y su empleo en España (Fuente: Bello, 2004; Tello y Bello, 2002)

\section{Alternativas Cultivos donde son eficaces*}

\begin{tabular}{lc}
\hline Alternativas no químicas & Hortalizas \\
Rotación de cultivos & Hortalizas \\
Enmiendas orgánicas y compost & Hortalizas, pimiento, flor cortada, vid \\
Biofumigación & Hortalizas \\
Prácticas culturales & Todos los cultivos \\
Medidas sanitarias & \\
Uso de semillas libres de patógenos y trasplantes & Tabaco, tomate, viveros, flor y pimiento \\
Cultivos sin suelo y sustratos & Tomate, clavel, pimiento \\
Variedades resistentes & Cucurbitáceas, pimiento y tomate \\
Injertos & \\
Resistencia inducida & \\
Agentes de control biológico & Hortalizas y fresón \\
Solarización & Flor cortada \\
Vapor de agua & \\
Fuego y otros medios físicos & \\
\hline
\end{tabular}

\begin{tabular}{lc}
\hline Alternativas químicas & \\
1,3 Dicloropropeno & \\
Metam-sodio & Fresón y flor cortada \\
Dazomet & Fresón \\
Combinaciones & Fresón y pimiento \\
\hline Control integrado & Tomates, hortalizas, pimiento, frutales \\
\hline \multicolumn{1}{c}{$*$ En blanco: cultivos sin especificar } &
\end{tabular}


Es a partir del año 1992 cuando las investigaciones en España tienden a buscar alternativas surgiendo una serie de proyectos que Bolívar (1998) clasificó en 7 grupos:

- Desarrollo de la solarización y su combinación con otros fumigantes

- Utilización de antagonistas para lucha biológica

- Reducción de emisiones a la atmósfera de bromuro de metilo mediante el empleo de plásticos virtualmente impermeables

- Utilización de las propiedades fumigantes de la materia orgánica (biofumigantes)

- Utilización de injertos sobre pies resistentes

- Manejo integrado del cultivo para disminuir el ataque de patógenos del suelo

- Estudios de viabilidad económica y de su aceptación por los productores de diversas alternativas: cultivos sin suelo, empleo de vapor de agua, etc.

No hay que olvidar que España ha sido uno de los países de referencia en la búsqueda de alternativas al BM debido a su gran consumo que le llevó a ocupar el cuarto puesto tras EE.UU., Italia y Japón (Bello y Díez Rojo, 2004).

\subsubsection{Alternativas químicas al $B M$}

Además de por su sencillez de aplicación, la desinfección química de los suelos se caracteriza por su elevada eficacia insecticida, nematicida, fungicida y herbicida. La toxicidad de los productos para tratamientos de suelos es un factor que aconseja limitar su utilización (Cenis, 1991) y como recoge Barres (2006), a la hora de seleccionar este tipo de desinfección conviene conocer el alcance medioambiental de los efectos de su aplicación así como de la evaporación y degradación de los productos químicos, de la formación de metabolitos, de su capacidad de percolación y de su posible traslocación en las plantas. 
No hay que olvidar que el fundamento de la desinfección de suelos o sustratos empleando productos químicos está basado en la capacidad que tienen dichos productos de pasar a estado gaseoso en el momento de ser liberados, haciéndose necesario el impedir el escape de dichos gases al medio ambiente reteniéndolos durante el tiempo necesario para que su acción resulte efectiva.

Junto con el BM, entre todos los métodos químicos de desinfección los más utilizados y cuyos efectos adquieren una mayor repercusión tanto en el medio ambiente como en los sistemas de cultivo han sido: la cloropicrina (PIC), el 1-3 dicloropropeno y los productos generadores de isotiocianato de metilo entre los que se encuentran el metam-sodio y el dazomet

Desde 1992, son múltiples los trabajos que recogen información sobre resultados de alternativas al BM. Así, respecto a las alternativas químicas, mientras muchas de las registradas y disponibles (Barres, 2006) tienen una buena actividad contra hongos, nematodos y malas hierbas, carecen del amplio espectro de acción del BM en preplantación, de aquí la necesidad de intentar aumentar efectividad con mezclas. Entre los métodos de control alternativos se encuentra el uso de otros fumigantes, destacando el 1,3-dicloropropeno (1,3-D), la cloropicrina (PIC), los generadores de isotiocianato de metilo como el metam-sodio y el dazomet, así como también son ampliamente conocidos y utilizados otros productos obtenidos de la mezcla de los anteriores como el telone (Barres, 2006; Rodríguez-Kábana, 1998; Matthiessen y Kirkegaard, 2006). De estas alternativas la que ha ofrecido mejores resultados ha sido la mezcla de 1,3-D con cloropicrina (Ajwa et al., 2003; Martin, 2003).

Recordando que el BM se incluye entre los fumigantes gaseosos de amplio espectro que se difunden y penetran rápidamente en el suelo, el empleo de dichos fumigantes queda restringido debido a su alto coste y a la necesidad de cubrir el suelo con plástico para retener los gases generados mientras actúan. Como una de las principales alternativas al BM se emplea el metam-sodio, caracterizado por ser menos potente, suponer un menor coste y generar isotiocianato de metilo una vez 
en contacto con el suelo húmedo (Smelt y Leistra, 1974). Precisamente ese isotiocianato posee un amplio espectro de actividad biológica contra nematodos, patógenos fúngicos, insectos y malas hierbas, no es gaseoso a temperatura ambiente por lo que se difunde a través del suelo disuelto en agua. Este método de actuación permite aplicaciones más uniformes al hacerlas aprovechando el riego mostrándose, además, altamente eficaz a distintas profundidades en suelos arenosos. Se aplica, al igual que todos los fumigantes, en altos volúmenes (dosis mínimas en España de unos 600 litros por hectárea siendo normales entre 10001200 litros) sin olvidar la importancia de la humedad del suelo ya que por muy altas que sean las dosis, sin la humedad adecuada no se observará efecto alguno (El Hadiri et al., 2003). Otras características del isotiocianato de metilo incluyen su rápida descomposición en compuestos inocuos (Turner y Corden, 1963) y, a pesar de su eficacia de amplio espectro, en el caso del empleo de metam-sodio este se encarece en muchos sistemas de producción, lo que conlleva la búsqueda de otras alternativas, aumentando durante los últimos años la demanda de alternativas biológicas ya que, como indican Matthiessen y Kirkegaard (2006) se prefiere su uso al de agentes sintéticos de amplio espectro.

Estos autores hacen referencia en sus trabajos a un fenómeno observado en las aplicaciones al suelo de isotiocianato de metilo, al igual que ocurre con muchos de los pesticidas no residuales, al ser susceptible de ser biodegradado por parte de algunos microorganismos (mayoritariamente bacterias) cuando se adaptan al medio, de modo que las poblaciones de dichos microorganismos, y tras una selección natural, son capaces de usar el pesticida como fuente nutricional y de energía. Este fenómeno se ha observado tanto en el uso de metam-sodio como de 1,3-D al ser susceptibles a este tipo de biodegradación. La cloropicrina, que normalmente se mezcla con 1,3-D se descompone mucho más rápido que el BM y, principalmente, por causas de degradación microbiana. Es en las últimas décadas cuando ya no se cuestiona que tanto la mineralización como la degradación 
completa de un compuesto en el medio ambiente es casi siempre consecuencia de una actividad microbiana (Alexander, 1980).

Volviendo al fenómeno de biodegradación, este podría estar relacionado sin duda con la frecuencia y número de aplicaciones del pesticida y con las propiedades del suelo, influyendo desde el $\mathrm{pH}$, al contenido en calcio y, por supuesto, al tipo de suelo. Así, Warton y Matthiessen (2005) modificando los niveles de $\mathrm{pH}$ y de calcio en un suelo arenoso, aceleraron la degradación de isotiocianato de metilo, pero únicamente al elevar los dos factores conjuntamente, ya que solos, ni un aumento en el $\mathrm{pH}$ ni en el contenido en calcio promovieron la biodegradación. Del mismo modo, consiguieron efectos diferentes con diferentes tipos de suelo, indicando que el tipo de suelo es un factor crucial que puede incluso anular la poderosa interacción calcio-pH.

La sustitución general del BM por 1,3-D, cloropicrina y metam-sodio, aumenta el riesgo de una rápida biodegradación en aquellos sistemas que no tienen experiencia en este fenómeno o, simplemente, lo desconocen. La prevención cuidando el manejo y frecuencia de aplicación resulta la mejor de las estrategias (Matthiessen y Kirkegaard, 2006).

Gullino et al. (2003) además de dazomet y metam-sodio, productos de los que indica su aplicación tanto en campo abierto como en cultivos protegidos, junto con cloropicrina y 1,3-D cita como alternativas químicas el tetratiocarbamato de sodio, formaldehído y las azidas inorgánicas de sodio y potasio (estas últimas todavía estaban en estudio) insistiendo en que desde un punto de vista técnico, la desinfección del suelo debe llevarse a cabo de una forma efectiva pero con costes aceptables, resultando el empleo de fumigantes un método con amplio espectro de actividad y costes relativamente bajos. Pese a su coste, inferior al de las alternativas no químicas, los fumigantes generadores de metil-isotiocianato resultan poco efectivos contra algunos patógenos vasculares así como contra patógenos con densidades de inóculo extremadamente elevadas mejorando su 
resultado cubriendo el suelo con capas plásticas tras su aplicación o recurriendo a otras combinaciones con alternativas no químicas.

Rodríguez-Kábana (1998) además de incluir en la lucha química el dibromuro de etileno (EDB) aporta resultados sobre el empleo de la azida de sodio (Rodríguez-Kábana, 2002) aplicada a través del agua de riego, en formulaciones líquidas, sin precisar de un equipo específico para su incorporación en el suelo. La azida de sodio, tóxica para humanos, también resultó tóxica para nematodos, malas hierbas y patógenos fúngicos del suelo debido a su potente acción de inhibición metabólica. No necesita de cubiertas plásticas tras su aplicación aunque estas mejoren su eficacia estando su actividad claramente influenciada por el $\mathrm{pH}$ del suelo, pero con las dosis ensayadas (100 a $150 \mathrm{~kg} \mathrm{ha}^{-1}$ ) los resultados fueron similares a los obtenidos con BM, contra malas hierbas y nematodos.

Por su parte, Ohr et al. (1996) estudiaron como alternativa el ioduro de metilo IM $\left(\mathrm{CH}_{3} \mathrm{I}\right)$ al ser análogo al $\mathrm{BM}$ en su capacidad biocida. Diversos estudios de campo y laboratorio demostraron una efectividad igual o incluso superior en el control de patógenos y malas hierbas sin estar implicado en la destrucción de la capa de ozono. El IM se distribuye uniformemente en el océano y es producido por algas marinas. Su ventaja radica en que sufre una fotolisis atmosférica eliminando los productos residuales en las capas bajas de la atmósfera estimándose el tiempo de permanencia en la misma entre 4 y 8 días en comparación con los dos años en el caso del BM. Respecto a sus características, el IM es líquido con su punto de ebullición en $42,5^{\circ} \mathrm{C}$ y se destruye rápidamente con la luz UV. Pese a la oportunidad de aprovechamiento de este producto y a sus resultados prometedores, no se han encontrado datos acerca de su elevada toxicidad (Bello y Tello, 1998) ni otros trabajos relevantes sobre su aplicación en la última década.

En nuestro país y debido a la existencia de cultivos de gran valor, entre los que se encuentra la fresa, se siguen solicitando "usos críticos" de BM, aunque se mantienen todos los esfuerzos en búsqueda de alternativas (Bolívar, 2002). Así, De Cal et al. (2004) evaluaron los distintos fumigantes de suelo citados anteriormente 
incluyendo el dimetilsulfóxido, todo ello en combinación con diferentes tipos de cobertura plástica, opción también elegida por otros grupos de investigación (Cebolla, 1998; Guerrero et al., 2002) basándose en que el polietileno (PE) de baja densidad normalmente usado como cerramiento en las desinfecciones de suelo, resulta permeable al BM escapándose grandes masas de gas. Una de las mejoras en las técnicas de aplicación es el uso de Films Virtualmente Impermeables (VIF) al BM para retener el gas evitando su emisión a través de la lámina de cobertura. Los plásticos VIF suelen ser más finos que los normales de PE estando formados por tres capas de manera que la interior suele ser de EVOH (Etil Vinil Alcohol) o Poliamida para conferir impermeabilidad a las dos externas de PE. Bello y Tello (1998) indican que aunque el empleo de estos plásticos permiten reducciones en las emisiones de hasta el $80 \%$ no supondrán una solución de futuro aportando datos sobre su elevado coste (de 4 euros $\mathrm{kg}^{-1}$ ) además de presentar una cierta fragilidad que da lugar a su ruptura, especialmente cuando se aplican mecánicamente.

Las mezcla de 1,3-D y cloropicrina aplicadas en el agua del riego se ha considerdo como alternativa al BM para la desinfección de suelos de invernaderos donde se practica el monocultivo de pimiento. Guerrero et al. (2006a) estudiaron el uso reiterado de estos productos en el control de Phytophthora y Meloidogyne concluyendo que la eficacia de la mezcla es estable cuando se reitera su uso en el mismo suelo. Del mismo modo se ha estudiado el empleo de dimetil disulfito y cloropicrina para la desinfección de estos suelos de invernaderos de pimientos (Martínez et al., 2006a) y la dosis adecuada de cloropicrina para controlar los mismos patógenos en las mismas condiciones de cultivo resultando las mejores dosis entre 40 y $50 \mathrm{~g} \mathrm{~m}^{-1}$ (Ros et al., 2006).

Según Tello y Bello (2002) se puede concluir que de las alternativas químicas al BM la mezcla de 1,3-D con cloropicrina (35\%) a la dosis de $40 \mathrm{cc} / \mathrm{m}^{2}$ tiene una elevada eficacia pero esta alternativa no puede considerarse debido a sus efectos cancerígenos y altamente contaminantes. Los tratamientos químicos 
empleando dazomet y metam-sodio en combinación con solarización ofrecen los mejores resultados en cultivos como fresones y zanahorias.

\subsubsection{Alternativas no químicas: solarización}

Como es conocido, el incremento de la presión social y legislativa para restringir el uso de fumigantes químicos ha creado un interés en evaluar el aprovechamiento de alternativas para el manejo de enfermedades del suelo (Chellemi et al.,1994) despuntando, entre estas, las distintas técnicas de desinfección no químicas.

De las alternativas al $\mathrm{BM}$ recogidas en la tabla 5, son tres las técnicas de desinfección no química que interesan en este trabajo: la solarización, la biofumigación y el empleo de microorganismos de control biológico, así como las posibilidades de combinación entre ellas.

Acerca de la solarización, se describe por primera vez por Katan et al. (1976) en Israel donde el método más usado hasta entonces para la desinfección de suelos era la fumigación siendo el alto coste de la misma su principal inconveniente, por lo que quedaba restringida a ciertos cultivos y épocas de cultivo. Se observó que al cubrir el suelo con láminas de polietileno transparente (figura 1), de unos $0,03 \mathrm{~mm}$ de espesor, durante las estaciones cálidas se incrementa su temperatura debido al calentamiento solar, lográndose una gran reducción en las poblaciones de determinados patógenos (principalmente hongos) que repercutía en la reducción de plantas afectadas por las enfermedades asociadas a los mismos. El método de control de enfermedades es similar al calentamiento artificial por vapor $\mathrm{u}$ otros medios, los cuales alcanzan temperaturas entre 60 a $100{ }^{\circ} \mathrm{C}$, pero existen importantes diferencias biológicas y tecnológicas; por ejemplo, con la solarización no es necesario conducir el calor desde su fuente al campo (Katan, 1981). Aunque el uso de láminas de polietileno para mulching en agricultura era en la época de los setenta una técnica relativamente nueva, lo que no lo era es la idea de usar calor solar para la protección de las plantas y menos en Israel donde el mulching de 
semilleros de tomate empleando serrín se utilizó en el valle del Jordán para incrementar la temperatura del aire del mismo por encima de los $46{ }^{\circ} \mathrm{C}$, previniendo la infestación de las plántulas de tomate con la mosca blanca del tabaco (Bemisia tabaci), el vector del TYLCV ("tomato yellow leaf curl virus"). Además, el efecto que ejerce el vapor de agua como desinfectante de suelos pudiendo matar a los patógenos pero dejando saprofitos competitivos se conocía de tiempo atrás, pudiendo actuar la solarización de forma similar, exceptuando las temperaturas máximas alcanzadas (que son menores) y el tiempo de tratamiento (que es mayor). Así, la solarización se consideraba como un tratamiento intermedio que en ocasiones sólo debilita o hiere a los patógenos sin matarlos (Elad et al., 1980; Katan et al., 1976).

En cuanto al efecto de la técnica, se sugiere que tanto un control biológico como térmico podrían tener lugar. Las temperaturas alcanzadas en las capas altas del suelo están en el rango de las que se consideran letales para los patógenos. En las capas más bajas del suelo, donde las temperaturas son inferiores, las poblaciones de patógenos, tras solarizar, también se reducen. Esto puede deberse tanto a un efecto acumulativo de temperatura subletal en los patógenos como a una combinación de control térmico y biológico. Para el control de hongos patógenos Katan et al. (1976) indicaron al menos tres maneras en las que el control biológico puede tener lugar en suelos que han sido cubiertos resultando muy interesante ya que puede aplicarse también al control de otros agentes patogénicos:

I) Fungistasis: que mantiene a los propágulos fúngicos en un estado de resistencia pasiva y se anula parcialmente a $45-50{ }^{\circ} \mathrm{C}$ así, los propágulos quedan expuestos a la acción de microorganismos líticos y a otros factores detrimentales del suelo.

II) Temperaturas subletales pueden debilitar las estructuras de resistencia haciéndolas más vulnerables a la microflora antagonista.

III) Creación de una modificación en las poblaciones microbianas del suelo a favor de los saprofitos resistentes al calor. Esto se espera ya que la mayoría de los 
patógenos son generalmente menos resistentes al calor que muchos saprofitos. Una consecuencia muy beneficiosa del cambio en la población microbiana en suelos cubiertos podría ser su protección a la reinfestación.

El control de numerosos patógenos del suelo, mayoritariamente fúngicos (Mansoori y Jaliani, 1996; Martyn, 1986), y bacterianos (Khlaif, 2003; Raio et al., 1997) junto con reducciones en la densidad de población de nemátodos se han logrado tras aplicar la técnica de solarización (Ashworth y Gaona, 1982; Chen y Katan, 1980; Katan, 1980; Katan, 1981; Pullman et al., 1981b; Stapleton y DeVay, 1982a; Stapleton y DeVay, 1983; Stapleton et al., 1983). 

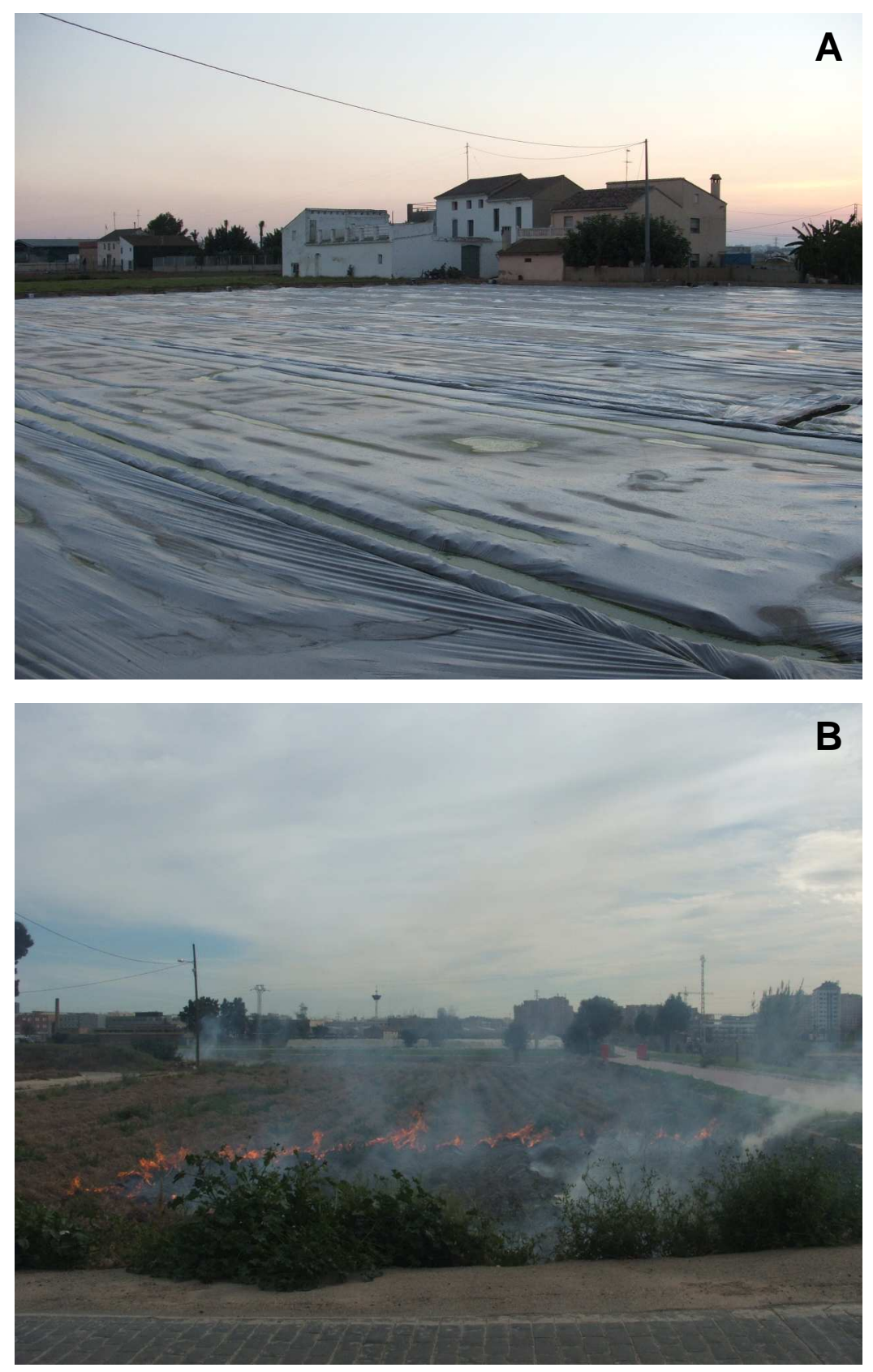

Figura 1. (A) Solarización. (B) Quema de restos en campos de chufa (Cyperus sculentum) (B) localizados ambos en la provincia de Valencia 


\subsubsection{Beneficios adicionales de la solarización: incremento de crecimiento}

Esta técnica se parece y recuerda a la fumigación del suelo y a los tratamientos térmicos en que tiene beneficios adicionales como son un control de las malas hierbas y una mejora tanto del crecimiento como del estado de las plantas (Katan et al., 1976; Gamliel et al., 1991; Gamliel y Katan, 1993), incluso se incrementa el rendimiento (Gamliel et al., 1989; Katan, 1981), si bien es cierto, que este fenómeno de crecimiento de las plantas en el suelo parcialmente esterilizado y libre de patógenos se conoce desde hace décadas y se ha observado en multitud de experimentos, incluyendo aquellos en los que el suelo se esteriliza con vapor o en los fumigados (Katan, 1981).

La solarización supera a la fumigación en que resulta más barata, más segura, no implica ni toxicidad ni la presencia de residuos de pesticidas y, además, no requiere maquinaria sofisticada. El cubrimiento del suelo puede llevarse a cabo de forma mecánica, a gran escala, o manualmente, permitiendo su bajo coste extender su uso a un amplio espectro de cultivos. Se reducen los riesgos de fitotoxicidad que tienen lugar a altas temperaturas y resulta menos dañino para el equilibrio biológico del suelo. Por lo tanto, se puede resumir como un método simple, que no conlleva riesgos y no implica materiales tóxicos (Mansoori y Jaliani, 1996); de este modo, se evitan ciertos efectos negativos observados con técnicas que emplean vapor de agua (Hoitink y Fahy, 1986; Chellemi et al., 1994) como la fitotoxicidad debido a la liberación de manganeso u otros productos tóxicos (Katan, 1981) así como su impacto ambiental (De Cara et al., 2004).

En determinadas zonas, la solarización es capaz de reducir el número de microorganismos fitopatógenos del suelo por debajo del punto en el que se convierten en factores limitantes para el crecimiento de las plantas (Stapleton y DeVay, 1984) y controla las malas hierbas, llegando a perdurar la efectividad del tratamiento un año entero, incluso más (Katan, 1981)

Las poblaciones de malas hierbas son muy diversas, pudiendo diferir en su sensibilidad al calor aunque, mayoritariamente, las malas hierbas anuales se 
controlan de manera efectiva siendo este control un beneficio adicional al considerarse cierta similitud con los patógenos pero con diferencias en cuanto a su sensibilidad al tratamiento solar (Katan, 1980; Katan, 1981).

$\mathrm{El}$ incremento de crecimiento de las plantas en suelos solarizados es un fenómeno muy bien documentado que se muestra en ausencia de patógenos conocidos y que se ha verificado en multitud de experiencias llevadas a cabo tanto en campo como en invernadero (Duniway, 2002; Gamliel y Katan, 1989; Gamliel y Katan, 1992; Greenberger et al., 1987; Kloepper y Schroth, 1981; Kloepper et al., 1980a; Kloepper et al., 1980b Stapleton y DeVay, 1982b; Stapleton y DeVay, 1984; Suslow y Schroth, 1982).

Son muchos los mecanismos que podrían ser responsables de este fenómeno, incluyendo la liberación de minerales en el suelo, la estimulación de microorganismos beneficiosos y el control de patógenos "menores" (Katan, 1981). Gamliel y Katan (1993) atribuyen esta respuesta a varios factores químicos, físicos y bióticos, al observar importantes cambios en la actividad microbiana durante y tras la solarización, indicando que los propios microorganismos del suelo juegan un papel crucial en el fenómeno del incremento del crecimiento. Indican estos autores que los suelos solarizados se vuelven supresivos a patógenos, es decir, en ellos las enfermedades causadas por determinados patógenos no se manifiestan o lo hacen mínimamente, a pesar de que dichos agentes están naturalmente presentes o han sido artificialmente introducidos (Diánez, 2005), ya que la supresividad (inducida) a enfermedades puede lograrse mediante la manipulación del ambiente físicoquímico y microbiológico (Whipps, 2000). En cambio, otros patógenos como las bacterias Pseudomonas fluorescentes aumentan tras solarizar, colonizando la rizosfera y las propias raíces tanto de suelo como de medios contenedores. En contraste con este hecho, se suprime el establecimiento de hongos en raíces y rizosfera tras la solarización (Gamliel y Katan, 1993).

El mayor crecimiento promovido por las pseudomonas se cree que se obtiene como consecuencia de un antagonismo, a través de una producción 
antibiótica, a través de mecanismos de competición con los patógenos por los nutrientes esenciales como el hierro o, más directamente, a través de la promoción del crecimiento ya que, algunos estudios sugieren que las pseudomonas fluorescentes pueden estimular el crecimiento de las plantas mediante la supresión de microorganismos dañinos (Schippers et al., 1987).

Stapleton y DeVay (1984) acuñan el término IGR del inglés "increased growth" y en español "Incremento del crecimiento" de modo que tras la solarización, dicho incremento supondrá un indicador normal de la aplicación satisfactoria del tratamiento (Katan, 1981; Pullman et al., 1981a; Stapleton y DeVay, 1982a; Stapleton y DeVay, 1983).

En otros estudios adicionales acerca de lo que ocurre al producirse este fenómeno, diversos autores apoyan la teoría de que tiene lugar cuando no se detectan en el suelo nemátodos ni patógenos superiores, entre los que se encuentran los hongos y las bacterias del suelo (Chen y Katan, 1980; Katan, 1981; Stapleton y DeVay, 1982b; Stapleton y DeVay, 1983). Otras veces, se apunta a un incremento en los niveles de nutrientes minerales solubles (Chen y Katan, 1980; Stapleton y DeVay, 1982a; Stapleton et al., 1983).

Acerca del aumento de estos minerales solubles tras solarizar, Stapleton et al. (1983) indican que tras un tratamiento de 6 semanas (con temperaturas entre 44 y $46{ }^{\circ} \mathrm{C}$ y profundidad de $15 \mathrm{~cm}$ ) se incrementaron los niveles de $\mathrm{NO}_{3}-$ y de $\mathrm{NH}_{4}$ en todos los suelos a profundidades de 0 a $15 \mathrm{~cm}$. Además, en ocasiones, se observó un incremento en fósforo, magnesio y calcio, acompañado de incrementos tanto de crecimiento como de peso (fresco y seco), comparando siempre con zonas no solarizadas y variando los resultados en función del tipo de suelo. Katan (1981) indica que también se incrementa la cantidad de potasio $\mathrm{K}^{+}$(junto a $\mathrm{NO}_{3}^{-}, \mathrm{NH}_{4}{ }^{+}$y $\mathrm{Ca}^{2+}$ ), así como de materiales orgánicos en todos aquellos suelos calentados de forma solar.

En aquellos suelos que son cubiertos con polietileno negro y donde tienen lugar pequeñas elevaciones en las temperaturas por calentamiento solar, también se 
observa un incremento del crecimiento de las plantas aunque lo normal es cubrir con polietileno transparente, como ya se ha indicado, durante un periodo de 4 a 6 semanas; lo que supondrá la esperada reducción de densidad poblacional de los microorganismos y nemátodos de suelo que es el efecto relacionado con el esperado incremento de crecimiento (Stapleton y DeVay, 1982b; Stapleton y DeVay, 1983).

Otros microorganismos beneficiosos como la bacteria Gram positiva Bacillus spp. son capaces de sobrevivir a la solarización del suelo, mostrándose beneficiosa, también, para el crecimiento de las plantas (Stapleton y DeVay, 1984). No hay que olvidar los importantes cambios biológicos causados por la técnica y que se asocian a la destrucción de importantes microorganismos mesófilos y que crean un "vacío biológico" parcial donde sustrato y nutrientes quedan disponibles para una recolonización, una vez finalizado el tratamiento. Muchos parásitos de las plantas que habitan el suelo y patógenos, no son capaces de competir con otros microorganismos adaptados a sobrevivir en el suelo, incluyendo a muchos antagonistas de plagas de plantas que recolonizarán más fácilmente el sustrato sobreviviendo a la solarización. Este grupo incluye a las bacterias Bacillus y Pseudomonas spp., hongos como Trichoderma y algunos nemátodos (Stapleton, 2000).

Otras ventajas del método incluyen su consideración dentro del control integrado al estar involucrados mecanismos físicos y también biológicos así como por controlar, de manera simultánea, una gran variedad de patógenos y de malas hierbas, como se ha indicado. Además, como se verá en epígrafes posteriores, la integración de la solarización con otros métodos de control puede incrementar sus beneficios (Katan, 1981).

\subsubsection{Solarización estructural}

La solarización estructural de los invernaderos, definida como tal por Shlevin et al. (2004 a y b), se incluye dentro de los procedimientos de saneamiento 
no químicos siendo una herramienta muy útil de desinfección para el control de aquellos inóculos que quedan adheridos a la estructura de invernaderos (como paredes y soportes) pudiendo convertirse en una fuente de reinfección de suelos desinfectados. El saneamiento reducirá la población de plagas evitando la supervivencia de patógenos (en tiempo y espacio) entre cultivos. Se trata de un aprovechamiento térmico ya que se lleva a cabo cerrando el invernadero durante un cierto periodo de tiempo (durante la estación apropiada) atrapando así, el calor en su interior, controlando los patógenos que persisten en suelo y/o en estructuras. Se considera un calor seco, con temperaturas máximas de $60{ }^{\circ} \mathrm{C}$ y una humedad relativa cercana al $15 \%$. No hay que olvidar, que el calentamiento en seco es menos efectivo para la inactivación de patógenos que el calentamiento húmedo y por ello, este tipo de solarización, necesita aplicarse durante varias semanas. Además de la temperatura, otros factores como la humedad resultan cruciales en el control de patógenos (Shlevin et al., 2003; Shlevin et al., 2004-b; Stapleton, 2000).

\subsubsection{Condiciones de la técnica}

La solarización se ha empleado en un gran número de países; en el año 1994 se contabilizaron un total de 38 países en los que la técnica se había evaluado para el control o supresión de diversos patógenos del suelo (Chellemi et al., 1994) siendo el objetivo principal el alcanzar una reducción económica en la incidencia de las enfermedades, aunque sea durante un ciclo de cultivo (Katan, 1981). Se aplica en tantas zonas que resulta inevitable las diferentes denominaciones adjudicadas a esta técnica (calentamiento solar, cubrimiento con plástico o PE, cobertura del suelo con PE) pero lo que más llama la atención es que también se puede considerar como una "pasteurización solar" ya que el método incluye calentamientos diarios y repetidos a temperaturas medias (Katan, 1981).

Entre las condiciones de aplicación, los resultados considerados como satisfactorios se obtienen en climas caracterizados como cálidos y con un régimen de pluviometría bajo (Chellemi et al., 1994). El cubrimiento del terreno debe 
llevarse a cabo durante el periodo de altas temperaturas e intensa radiación solar, por lo que la consideración de las condiciones meteorológicas más favorables es un punto importante a tener en cuenta (Katan, 1981).

Entre los principios de la solarización de Katan (1981), este autor indica que a la hora de cubrir el suelo, este deberá permanecer húmedo consiguiéndose un incremento de la sensibilidad térmica de las estructuras de resistencia de los patógenos y mejorando la conductividad del calor. Otros estudios anteriores (Katan et al., 1976) confieren gran importancia a la superficie de terreno cubierta, ya que al emplear tiras de plástico quedan zonas de suelo sin proteger, donde continuará la presencia de patógenos y, por lo tanto, aumenta el peligro de reinfectación.

\subsubsection{Mecanismos para el control de enfermedades mediante solarización}

Katan (1981) indica que la reducción de la incidencia de la enfermedad que se observa tras el tratamiento, es el resultado de los efectos de la solarización sobre cada uno de los tres componentes involucrados en la enfermedad: huésped, patógeno y ambiente tanto físico como químico; y estos efectos pueden continuar tras la retirada de los plásticos, incluso de la plantación.

El mayor efecto obtenido tras cubrir el suelo con plástico será, lógicamente, físico al provocarse un incremento en la temperatura durante varias horas al día. Pero otros efectos que incluyen cambios en las poblaciones de microorganismos, en la estructura física y composición química del suelo, un incremento de humedad bajo el plástico junto con cambios en la composición de gases del suelo, son efectos a considerar al analizar los mecanismos de control de la enfermedad.

Referente al mecanismo de inactivación térmica de los patógenos, este mismo autor indica que cuando los organismos están sometidos a calor húmedo, su viabilidad se ve reducida. El ratio de muerte térmica dependerá tanto de la temperatura como de tiempo de exposición, factores que están inversamente relacionados. Así, a una temperatura dada, y a un tiempo de exposición 
determinado, el ratio de mortalidad dependerá tanto de la sensibilidad inherente de los organismos al calor como a las condiciones ambientales.

Ya se ha indicado en varias ocasiones, la importancia del nivel de humedad y que resulta un factor crucial en el buen funcionamiento de la técnica (Katan, 1981; Shlevin et al., 2004-b); su mecanismo para el control de patógenos está basado en la mayor resistencia de los microorganismos al calor bajo condiciones secas. El efecto de la humedad puede explicarse por la "estabilidad calórica" (del inglés "heat stability") de las proteínas (Katan, 1981) según la cual, en presencia de agua se requiere menos energía para desplegar la cadena peptídica de las proteínas implicando una disminución en la resistencia al calor. Mediante el calentamiento de suelos secos, el control de los patógenos no resulta efectivo, así que en zonas áridas y aunque las temperaturas de los suelos desnudos son similares a las alcanzadas en suelos solarizados, el efecto de la técnica no es el deseado. Se ha sugerido que los organismos que requieren una temperatura máxima de crecimiento mayor que la de otros, son también más resistentes al calor letal, lo que se conoce muy bien en los organismos termófilos (Katan, 1981; Diánez, 2005).

\subsubsection{Limitaciones de la solarización}

Entre sus principales limitaciones se encuentra el hecho de que sólo se puede utilizar en regiones con climas adecuados y donde el suelo pueda permanecer libre de cultivos durante un periodo mínimo de un mes o incluso durante todo el verano (lo que no encaja bien en ciertas rotaciones de cultivo) recomendando zonas de elevada temperatura e insolación estival con máximas por encima de los $32-34{ }^{\circ} \mathrm{C}$, dependiendo de las altas temperaturas del aire, resultando más efectiva cerca de la superficie del suelo y precisando su puesta en marcha de disponibilidad de film plástico. Además puede resultar un método caro en el caso de determinados cultivos y resultar poco efectivo en el control de determinadas enfermedades causadas por plagas tolerantes al calor; tolerancia que podría aparecer tras aplicaciones repetidas de la técnica e incluso se puede incrementar la 
población de patógenos por posibles efectos dañinos en sus antagonistas. Del mismo modo en que tiene lugar un incremento de crecimiento de las plantas, por razones contrarias a este podría producirse una disminución del mismo. Por último, la variabilidad de sus resultados, derivada de la variación del clima, hace que sus efectos sean relativamente impredecibles, exceptuando zonas muy cálidas y secas, característica que resulta problemática con las necesidades de la producción hortícola intensiva, que no permite la toma de riesgos en cuanto al control fitosanitario (Cenis, 1991; Katan, 1981; Stapleton, 2000)

Sin embargo, todas las limitaciones que se acaban de indicar, también afectan a cualquier otro método de desinfección de suelos, por lo que, como ocurre para cualquiera de las técnicas de desinfección a implantar, el uso de la solarización debería ser evaluado en cada caso.

Algunos autores como Cenis (1991) sugieren que, debido a la alta variabilidad de sus resultados, antes de iniciar tratamientos a gran escala y que implican una considerable inversión, es aconsejable realizar pequeños ensayos que permitan una primera idea del rango de temperaturas que pueden alcanzarse $y$, por tanto, de la eficacia de la técnica en determinadas condiciones.

\subsubsection{Alternativas no químicas: biofumigación}

El término biofumigación fue propuesto por J.A. Kirkegaard (Kirkegaard et al., 1993) para hacer referencia a los efectos supresivos asociados a la liberación de isotiocianatos durante la hidrólisis de los glucosinolatos presentes en las Brassicas (Rosa et al, 1997; Kirkegaard y Matthiessen, 2004; Lazzeri et al., 2004; Matthiessen y Shackleton, 2005). Estos isotiocianatos tienen actividad biológica (Ahmad y Warren, 2003; Angus et al., 1994) siendo comparable a la del metamsodio, pesticida de amplio espectro y caracterizado (como se recoge en apartados anteriores) por generar metil-isotiocianato. Considerando esta definición, se acentúa el interés por el aprovechamiento de dichos gases para el control de plagas y enfermedades del suelo (Davis et al., 1996; Gimsing et al., 2007;Johnson et al., 
1992; McLeod y Steele, 1999; Mojtaheedi et al., 1993; Muelchen et al., 1990; Stephens et al., 1999) intentando abarcar, de una forma simple, un concepto para el fenómeno que incluye los efectos alelopáticos observados durante siglos en asociación con las Brassicas (Matthiessen y Kirkegaard, 2006).

Desde esta primera acepción, el adjetivo "biofumigante" ha entrado a formar parte del léxico empleado para el manejo de plagas ya que el concepto se amplia y se aplica al efecto beneficioso de los compuestos volátiles liberados en el suelo a partir de la descomposición de la materia orgánica y de los residuos agroindustriales (Bello, 1998; Bello et al., 2002; Stapleton, 2000).

Tello y Bello (2002), definen biofumigación como "la acción de sustancias volátiles producidas en la biodegradación de la materia orgánica en el control de los patógenos de las plantas" aumentando la eficacia de la técnica cuando forma parte de un sistema de producción integrada. De esta forma, la biofumigación se considera una alternativa no química al BM (MBOTC, 1997) que regula la presencia de patógenos del suelo a través de los procesos de degradación de la materia orgánica (Bello et al., 1997 a; 1997 b). Los gases obtenidos son el resultado de la biodescomposición de esta materia orgánica mediante el efecto biomejorador de los organismos del suelo o de aquellos que se encuentran asociados a las enmiendas orgánicas sin conocerse efectos negativos sobre el ambiente y la salud (Bello et al., 2000).

Para prolongar el efecto de la biofumigación se precisa de un manejo adecuado del sistema agrario, especialmente de la relación plantas-medio ambiente. De ahí la necesidad de un diseño de manejo integrado que debería considerar la realidad social y económica de cada zona, e incluso un estudio de sus características agroecológicas particulares (Bello, 1998). La técnica se ha ensayado usando una amplia variedad de materias orgánicas ya que cualquier resto orgánico puede actuar como biofumigante, dependiendo la eficacia de sus características, dosis y método de aplicación. Se han estudiado los efectos de estiércol de ganado (cabra, oveja, vaca y gallinaza), residuos de cultivos de arroz, residuos de 
industrias forestales y de papel, residuos de industrias de pescado y marisco, numerosos subproductos agrícolas (incluso desechos de jardines), comida y otras industrias así como residuos procedentes de plantas que presentan compuestos con efectos alelopáticos, donde incluiríamos a las brassicas (Bello et al., 2000; Bello et al., 2002).

Al añadir la materia orgánica al suelo se producen una serie de cambios microbiológicos y el incremento de la actividad microbiana lleva asociado un incremento de los niveles enzimáticos del suelo, todo ello le confiere a la técnica la misma eficacia que los pesticidas convencionales en el control de nematodos, hongos, bacterias, insectos, malas hierbas y se regulan los problemas con virus controlando a los organismos vectores.

Durante la biodescomposición de la materia orgánica se liberan gran cantidad de productos químicos que ayudan al control de los patógenos del suelo. Entre estos compuestos se encuentran amoniaco, nitratos, sulfuro de hidrógeno, ácidos orgánicos, un gran número de otras sustancias volátiles así como enzimas (peroxidasas, quitinas) y fenoles (Barres, 2006; Bello et al., 1997 b; Gamliel y Stapleton 1993; Rodríguez-Kábana 1998). Acerca de la liberación de gases, ya en 1970, Lewis y Papaverizas(1970; 1971; 1974), publicaron que las hojas de crucíferas y tejidos de sus tallos se descomponían en el suelo formando compuestos azufrados volátiles (metanetiol, sulfuro de dimetilo y disulfuro de dimetilo) detectándose por cromatografía de gases desde la primera y hasta la cuarta semana de su descomposición. Estos autores citan como fuentes con un mismo comportamiento las coles rizadas, mostaza, coles de bruselas o nabos, sorprendiendo como dato que también se detectaron otros compuestos (metanol, etanol, acetona, quetonas acetaldehído y aldehídos desconocidos) tanto en brassicas como en ensayos con maíz (Zea mays), curiosamente base del desarrollo actual de biocombustibles.

De entre los diferentes productos liberados a partir de la materia orgánica, la cantidad de amoniaco variará con los niveles de nitrógeno del sustrato orgánico, 
siendo también importante el contenido en carbono al depender de éste la metabolización del nitrógeno, de modo que, en ausencia de fuentes del carbono, el amoniaco y los nitratos pueden acumularse y causar fitotoxicidad. Atendiendo a la legislación relativa a la protección de aguas contra la contaminación producida por los nitratos usados en agricultura (Directiva 91/676/CEE) se marca la cantidad de $170 \mathrm{~kg} \mathrm{ha}^{-1}$ como aportación máxima (Cebolla et al., 2004; Ramos et al., 2004).

Para la detección de problemas aparecidos debido a un mal manejo de la técnica se utilizan distintas especies de brassicas como bioindicadores. Estas se seleccionan debido al bajo coste de la semilla que no tiene problemas técnicos de siembra (excepto la necesidad de riego abundante) y a su rápida germinación. Las semillas son sensibles a las sustancias fitotóxicas pudiendo actuar como plantas trampa e incorporarlas posteriormente al suelo, como biofumigantes (Tello y Bello, 2002).

Otro de los problemas relacionados con la biofumigación es el impacto ambiental producido por la capa de plástico requerida para atrapar los gases procedentes de la descomposición de la materia orgánica. Este problema puede solucionarse pasando un rodillo que compacte el terreno y manteniendo el suelo húmedo durante todo el proceso de biofumigación (técnica con resultado altamente satisfactorio en el caso de los suelos arcillosos). Se han realizado estudios novedosos sobre el impacto de las láminas plásticas empleadas en agricultura como el publicado por Van der Meulen et al. (2006) que cabe comentar por su curiosidad ya que se estudia el efecto de las cubiertas plásticas que han sido abandonadas en Lorca (Valle del Guadalentín) al ser troceadas y mezcladas con el suelo, observando que no afectan a la estabilidad de los agregados ni a la porosidad, incluso se mejoraron las condiciones hidrológicas previniendo la evaporación’de la humedad. Pero es importante que las láminas sean troceadas ya que abandonarlas imperturbables implicaría problemas de erosión de barrancos y escorrentias.

Para un resultado óptimo se precisa la adición de grandes cantidades de materia orgánica al suelo (valores superiores a $50 \mathrm{tn} \mathrm{ha}^{-1}$ ) quedando su uso limitado 
por la disponibilidad de material y por el coste del transporte, problema este último fácilmente eludible si se emplean residuos agrarios o urbanos cercanos al lugar de aplicación.

\subsubsection{Condiciones de la técnica}

Bello et al. (2002) catalogan la biofumigación como una técnica fácil para agricultores y técnicos que, como ya se ha comentado anteriormente, sólo difiere de las enmiendas orgánicas en la elección del biofumigante que deberá ser parcialmente descompuesto, así como en el método de aplicación. Este método debe considerar la necesidad de retener, por lo menos durante dos semanas los gases producidos, ya que su efecto, en la mayoría de los casos, no es biocida, sino biostático. Por esta razón se precisará prolongar su tiempo de acción sobre los patógenos. Se ha demostrado que cualquier residuo agroindustrial o aquellas combinaciones con una relación $\mathrm{C} / \mathrm{N}$ entre 8-20 pueden tener un efecto biofumigante, evitando efectos fitotóxicos sobre los cultivos sin perder actividad biocida (Rodríguez-Kábana, et al., 1983). Como ya se ha indicado, el uso de una dosis de $50 \mathrm{t} \mathrm{ha}^{-1}$ es recomendable, aunque cuando los problemas con hongos y nematodos son muy serios, la dosis debería incrementarse a $100 \mathrm{tn} \mathrm{ha}^{-1}$. Cantidades extremadamente elevadas pueden reducirse a través de técnicas de cultivo como, por ejemplo, la aplicación en surcos.

La biofumigación surge como variante de la adición de enmiendas orgánicas al suelo (Piedra Buena et al., 2007). La técnica se diferencia del uso de estas enmiendas por las características de los materiales utilizados, dosis y método de aplicación (Tello, 2002). Para que un material orgánico tenga función biofumigante debe estar en las primeras fases de descomposición, lo que no sucede con la materia orgánica que se agrega normalmente como abono (García-Álvarez y Bello, 2004) que se trata de materia orgánica estabilizada (compost o estiércoles maduros) (Piedra Buena et al., 2006). 
Según la metodología explicada por estos mismos autores (Tello y Bello, 2002), los biofumigantes deben esparcirse de forma uniforme para que no aparezcan focos de patógenos en las zonas no tratadas, ya que estos focos podrían resultar en problemas para el cultivo. Una vez esparcido, el biofumigante debe ser incorporado de forma inmediata en el suelo y, tras un pase de rotovator, se riega el terreno, preferiblemente por aspersión aunque se puede regar a manta o instalar goteros, hasta que el suelo queda saturado. Una vez finalizado el proceso se cubre el terreno con plástico durante al menos dos semanas, evitando la salida de los gases producidos en la biodegradación de la materia orgánica. Cuando los suelos son poco profundos $(<30 \mathrm{~cm})$ no se necesita el uso de plásticos, y los gases se retienen con la aplicación de riegos frecuentes que mantengan una delgada capa de arcilla en la superficie, recomendando efectuar la biofumigación cuando las temperaturas superan $\operatorname{los} 20^{\circ} \mathrm{C}$, aunque la temperatura no es un factor limitante (Bello et al., 2003).

Puede aparecer alguna dificultad en los primeros tratamientos de biofumigación, pero a medida que pasa el tiempo, el agricultor se va familiarizando con el método, seleccionando las dosis más eficaces, tanto desde el punto de vista de su eficacia en el control de patógenos como desde el punto de vista económico (Tello y Bello, 2002).

\subsubsection{Materia orgánica y biofumigación}

Al considerarse la biofumigación una variante de la adición de materia orgánica al suelo, cabe recordar que el empleo de ésta para mejorar la fertilidad y controlar plagas y enfermedades es una práctica casi tan antigua como la agricultura (Bello et al., 2003) y los propios científicos reconocieron, hace mucho tiempo, la importancia de esta materia orgánica como el factor más importante que influye en las propiedades químicas de los suelos (Chiu et al., 2003).

Existen datos más que suficientes que indican que la materia orgánica reduce la incidencia de enfermedades causadas por un amplio rango de patógenos y 
plagas de plantas incluyendo bacterias, hongos y nemátodos (Abawi y Widmer, 2000; Conn y Lazarovits, 2000; Cook, 1986; Gamliel et al., 2000; Lazarovits et al., 2001). En la adición de la materia orgánica estos autores se centran en aquellas enmiendas con alto contenido en nitrógeno, estiércoles y composts, estos últimos como agentes de biocontrol responsables de condiciones de supresividad a enfermedades.

Entre los principales problemas en el empleo de enmiendas orgánicas aparecen su falta de homogeneidad, la acumulación de compuestos contaminantes y de metales pesados. De todos estos, el mayor problema al que se enfrentan los agricultores en el empleo de enmiendas orgánicas es la heterogeneidad en la composición de la materia utilizada en su preparación requiriendo metodologías apropiadas que eviten la acumulación de compuestos dañinos o, incluso, el incremento del inóculo de ciertos patógenos en el suelo debido a un mal manejo. Por todo ello, es necesario el diseño de metodologías para la caracterización agronómica y fitosanitaria de los materiales empleados, así como el desarrollo de técnicas adecuadas de aplicación en campo.

La materia orgánica es una fuente de elementos fertilizantes, especialmente de $\mathrm{N}$, que si bien se aporta en forma orgánica poco apropiada para una asimilación rápida y directa de los vegetales, gracias a los organismos asociados y a los presentes en el suelo se transforma en nitrógeno amoniacal primero y nítrico después, quedando de forma asimilable. La adición de esta materia orgánica se realiza en un avanzado estado de descomposición, en su estado perfecto de humus (Aguirre, 1963). Las enmiendas (abonos orgánicos que incluyen estiércoles, abonos verdes, basuras, gallinaza, etc.) son más pobres en principios fertilizantes que los abonos minerales, pero la inmensa población microbiana que aportan tiene efectos muy favorables, especialmente en la estructura del suelo; el menor contenido en fertilizantes se resuelve aumentando la dosis de dichas enmiendas. Aún así, los abonos minerales y orgánicos no se excluyen sino que se complementan. Respecto al abonado en verde (que se prefiere realizarlo con leguminosas) no hay que 
descuidar el encalado que facilite la descomposición del material aportado, excepto en aquellos suelos clasificados como cálcicos. Por último, para terminar con esta revisión, desde antiguo se practica el aporte de rastrojos como fuente de materia orgánica, aprovechando los residuos que dejan las cosechas. Con estos restos eran dos las formas de actuar: o se quemaban y se convertían en cenizas o se enterraban. En caso de elección de esta segunda opción, hay que activar su transformación en humus, por ejemplo, aplicando cualquier fórmula de fertilización nitrogenada evitando un desequilibrio carbono/nitrógeno desfavorable para los microorganismos encargados de la humificación (Aguirre, 1971).

Hay que intentar comprender el modo de acción de las enmiendas para poder mejorar su efectividad y poder incluirlas en los sistemas de producción de cultivos (Lazarovits et al., 2001).

Muchos son los mecanismos involucrados en el control de patógenos incluyendo la acción de los compuestos que resultan tóxicos (Shetty et al., 2000; Tsao y Oster, 1981), la alteración de las propiedades del suelo que afectan la supervivencia de los organismos (Keinath, 1996), la estimulación de la actividad de los organismos de control biológico (Dutta e Isaac, 1979; Jordan et al., 1972) así como la mejora e inducción de resistencias (Hoitink y Boehm, 1999).

Respecto a los compuestos tóxicos contenidos en las enmiendas orgánicas, pueden estar pre-formados dentro de las plantas como los fenoles, taninos, azadiractina y ricinina o derivar del proceso de descomposición de la materia orgánica en el suelo, como amonio, nitritos, acetaldehído, formaldehído, isotiocianatos y sulfuro de hidrógeno (Piedra Buena, 2004).

Desde antiguo se han ensayado una amplia variedad de materiales como enmiendas capaces de controlar enfermedades transmitidas por el suelo (Cook y Baker, 1983). Del mismo modo que desde los años 20 se ha documentado que las enmiendas orgánicas son capaces de controlar determinados patógenos del suelo o la enfermedad que estos causan en las plantas (Fellows, 1929; Gilpatrick, 1969; Jordan et al., 1972; Tsao y Oster, 1981; Wilhem 1951; Zentmyer, 1963), no hay 
que olvidar que también pueden incrementar el efecto de determinadas enfermedades (Chattopadhyay y Mustafee, 1978; Huber y Anderson, 1976; McIlven y Cole, 1977; Wilhem, 1951) como ocurre en el caso de los cultivos de patatas con la sarna común (Streptomyces scabies), aconsejando no emplear estiércoles frescos de animales en suelos destinados a su producción (Lazarovits et al., 2001). Respecto al empleo de mezclas, Sun y Huang (1985) emplearon una compleja mezcla a base de subproductos derivados de la agricultura, acuicultura y de la industria del acero como fuente de materia orgánica e inorgánica e incluso llegan controlar la presencia de algunos patógenos además de intentar potenciar el crecimiento de las plantas añadiendo diferentes combinaciones de fertilizantes. La mezcla que ensayaron contenía desde biomasa procedente del cultivo de caña de azúcar, cascarilla de arroz, polvo de conchas de ostras, urea, nitrato potásico, superfosfato cálcico y un alto porcentaje de cenizas minerales. Aplicaron esta mezcla, muy rica en calcio, inhibiendo la germinación de esporas de algunos hongos (Fusarium oxysporum f. sp. niveum y f. sp. raphani;), reduciendo el porcentaje de plantas afectadas con Plasmodiophora brassicae, controlando las enfemedades causada por Phytophthora melonis, Rhizoctonia solani, Sclerotium rolfsii, y reduciendo drásticamente las poblaciones de la bacteria Ralstonia solanacearum .

Los beneficios de aplicar enmiendas orgánicas para el control de enfermedades transmitidas por el suelo pueden tener efectos acumulativos (Bailey y Lazarovits, 2003).

También se han empleado como enmiendas al suelo materiales con un alto contenido en nitrógeno que generan amoniaco, entre ellos la adición de quitina o materiales quitinosos que no sólo generan amoniaco, sino que estimulan las actividades de la microflora quitinolítica del suelo (Bello et al., 2003). Lazarovits et al. (2001) corroboran que el mecanismo de control ejercido por las enmiendas con un alto contenido en nitrógeno se debe a la formación de amoniaco y de ácido nitroso durante el proceso de degradación por parte de los microorganismos del 
suelo y, que en un suelo se alcancen, o no, concentraciones letales para los patógenos depende del $\mathrm{pH}$, de la cantidad de materia orgánica aportada, de la velocidad de nitrificación, del contenido en arena y de su capacidad tampón.

La incorporación al suelo de enmiendas con alto contenido en nitrógeno (materiales ricos en proteínas, ricos en quitina, estiércoles animales y restos de plantas) pueden controlar un gran número de patógenos y plagas (Aryantha et al., 2000; Bell et al., 1998; Candole y Rothrock, 1997; Kaplan y Noe, 1993; Zakaria y Lockwood, 1980). La muerte de los patógenos se atribuye a diferentes efectos incluyendo el incremento en la actividad de los organismos de control biológico (Dutta e Isaac, 1979; Jordan et al., 1972), a la generación de condiciones anaeróbicas (Blok et al., 2000) y a la acumulación de amoniaco. El papel de este producto en el control de organismos patógenos ha sido ampliamente estudiado a lo largo de los años (Gilpatrick, 1969; Huber y Watson, 1970; DePasquale y Montville, 1990; Michel y Mew, 1998; Punja y Grogan, 1982; Tsao y Oster, 1981; Chun y Lockwood, 1985; Smiley et al, 1970).

Para Lazcano et al. (2004) el exceso de residuos orgánicos (especialmente los procedentes de la ganadería industrial) y las dificultades derivadas de su aplicación directa a los cultivos, hacen necesaria su transformación en un material más estable, no agresivo para las plantas y no contaminante, convirtiéndose en un producto agronómicamente útil que pueda ser utilizado como enmienda orgánica en suelos.

Estos últimos autores indican que, tanto en condiciones de laboratorio como en campo, la biofumigación estimula la actividad biológica de los suelos incrementando las poblaciones de antagonistas de patógenos como las bacterias Pseudomonas fluorescens o Bacillus spp. En función de estos resultados, existiría una relación entre la actividad biológica de los suelos y la supresión de la actividad patogénica.

Cuando se usa la biofumigación es preciso diseñar una metodología adecuada a cada situación. Lo que puede encarecer el proceso es la elección de 
tratamientos con estiércoles animales debido al transporte, pero el coste puede disminuirse usando técnicas agrícolas que disminuyan la dosis de aplicación y recurriendo al empleo de recursos locales.

\subsubsection{Efectos de la biofumigación: problemática de los restos de cosechas}

En la adición de materia orgánica al suelo, son los materiales más recientes, especialmente si se trata de restos de plantas, los que se descomponen mucho más deprisa que la materia orgánica propia del suelo y como efecto asociado aceleran la descomposición de la misma (Broadbent, 1947; Thompson, 1962).

En la revisión realizada por Bello et al. (2002) se recoge que la biofumigación tiene un efecto beneficioso en las propiedades físicas del suelo, particularmente respecto a su compactación. En algunos tratamientos con brassicas, cáscara de arroz, cáscara de caña de azúcar, pasta húmeda de olivo y paja de cereales, aparece un descenso en el contenido de nitrógeno, volviendo a remarcar la importancia de establecer programas de fertilización que consideren las características no sólo del biofumigante, sino también del suelo donde se aplica (Matthiessen et al., 2004). No hay que olvidar que algunos productos pueden acumular compuestos peligrosos e incrementar los niveles de algunos patógenos edáficos.

Especialmente cuando se recurre a combinaciones, se pueden producir estos fenómenos tanto de fitotoxicidad como de deficiencia en nitrógeno. Se recomienda alternar el empleo de residuos agrarios con abonos verdes, especialmente de brassicas empleando de 5 a $8 \mathrm{~kg} \mathrm{~m}^{-2}$ de materia verde, aunque también se pueden aplicar combinaciones de leguminosas con gramíneas. En el caso de usar abonos verdes cultivados en la misma parcela, deben utilizarse plantas de crecimiento rápido para incorporarlas al menos a los 30 días de haberlas sembrado e impedir que se incrementen las poblaciones de patógenos. 
La biofumigación se ha establecido como una práctica habitual que permite la utilización de recursos locales en el control de patógenos de las plantas, disminuyendo los costes de producción y transformando a la agricultura en una alternativa para resolver problemas de impacto ambiental, como los creados por los residuos de cosechas y de la agroindustria (Bello et al., 2003).

En los últimos años son múltiples los trabajos dedicados al estudio del control de enfermedades transmitidas por el suelo con el manejo adecuado de restos de cultivos (Bailey y Lazarovits, 2003). Estos residuos considerados como desperdicios sin ningún valor y que son catalogados como fuente de contaminación pueden usarse como materiales biofumigantes (Piedra Buena et al., 2007). Mediante su incorporación al suelo, se aprovechan los metabolitos secundarios producidos en el interior de los tejidos vegetales y que se liberan durante su proceso de descomposición (Gamliel et al., 2000). Usando los residuos de cosecha como biofumigantes, se liberan, principalmente, aldehídos e isotiocianatos, ambos con actividad biocida (Abawi y Widmer, 2000; García-Álvarez et al., 2004).

En España se generan toneladas de restos de cosecha que son abandonados en los suelos, convirtiéndose en un foco importante de plagas y enfermedades. En el año 2003, la cifra de estos restos superaba los 2000 millones de $\mathrm{kg}$ (Uclés Aguilera y Hernández Torrecillas, 2003) concentrándose de forma mayoritaria en las zonas de agricultura intensiva donde, ante estas cifras, los procesos naturales de degradación no eran suficientes. Camacho Ferre (2004) recordaba que el residuo de biomasa generado desde siempre por la agricultura tradicional no generaba problemas empleándose, de forma mayoritaria, como alimento para el ganado o los restos se degradaban de forma natural incorporándose al ciclo trófico (abono orgánico o alimento animal). Este último autor coincide en que la producción de residuos de forma concentrada (zonas y época) en agricultura intensiva hace inevitable su acumulación, además de haberse disminuido el aprovechamiento animal debido a la composición muy variada y mixta (cuando se mezclan material vegetal y rafias). Como principal objetivo se plantea un aprovechamiento de estos 
restos a la vez que una disminución en su impacto medioambiental. A las distintas alternativas citadas por Camacho Ferre (compostaje, incineración o generación de energía), Piedra Buena (2004) añade un uso como material biofumigante lo que revalorizaría estos materiales que ya no serían "desechos" sino "subproductos" del sistema con capacidad de aportar mejoras sobre la fertilidad de los suelos y en el control de patógenos.

Sobre los restos de cosecha, Aguilar (2002) centra su trabajo en Almería, concretamente en la zona de Campo de Dalías, uno de los lugares con mayor concentración de invernaderos, ampliándose los problemas de contaminación no sólo a estos residuos sino también a la gran cantidad de plástico (Escobar, 1997). La generación de residuos en las zonas de explotación intensiva se prolonga durante todos los meses del año, pero las épocas de máxima producción coinciden con los ciclos productivos mayoritarios en los invernaderos (Enero-Febrero y Mayo-Junio). Al problema de la composición mixta de los restos se añade una acumulación, en ocasiones excesiva, de plaguicidas sumándose a la imposibilidad de consumo por parte del ganado. Por otra parte, la incineración o quema de restos (figura 1) no parece un método muy recomendable, no sólo por la contaminación medioambiental debida a emisiones de $\mathrm{CO}_{2}$, sino también por el riesgo de incendios (Escobar, 1997).

Los restos de cosecha son, a menudo, portadores de insectos, ácaros y diversos patógenos de naturaleza fúngica, vírica o bacteriana, siendo más que conocida la capacidad de permanencia viable de algunos de estos patógenos sobre los restos vegetales, que pueden permanecer infectivos durante años, como ocurre con el caso de algunos virus como el virus de mosaico del tomate ToMV (Vilaseca, 2007), o de algunas bacterias de los géneros Clavibacter, Agrobacterium, Erwinia, Pseudomonas, Ralstonia y Pseudomonas (Vidaver y Lambrecht, 2004; Biosca et al., 2003). Estos restos infectados con agentes fitopatógenos, también pueden servir de fuente de inóculo para los cultivos colindantes (Aguilar, 2002). La eliminación de los restos vegetales de las inmediaciones de los invernaderos se considera un 
método preventivo de luchar contra plagas y enfermedades de los cultivos hortícolas, tanto en fitopatología como en los sistemas de producción integrada (Aparicio et al., 1995) ya que, incluso a cierta distancia, los patógenos presentes en los residuos pueden constituir el inóculo primario para ocasionar enfermedad al cultivo.

Bailey y Lazarovits (2003) indican que el manejo de restos de cultivo depende de su descomposición pero con el objetivo de devolver al suelo el carbono orgánico. La descomposición de estos residuos podrá variar en función de la profundidad en la que quedan dispuestos en el suelo, del tipo de cultivo y cantidad de restos adicionada, de las interaccionnes alelopáticas entre la biota del suelo y del tiempo transcurrido desde su aporte. Estudian el control de enfermadedes transmitidas a través del suelo y se centran en el hongo Cochliobolus sativus (Ito y Kuribayashi) Drechs. ex Dastur, causante de la podredumbre común de cereales. Entre sus conclusiones encuentran que, trabajando con paja de trigo, su descomposición es mayor cuando se entierra que cuando se deja sobre la superficie del terreno con una diferencia en el tiempo transcurrido hasta su total descomposición de 17 meses.

En el manejo de materia orgánica, según Bello et al. (2004), se debe procurar la creación de sistemas cerrados, que devuelvan al suelo aquellos materiales que proceden de él, para que no se conviertan en fuente de contaminación por restos de cultivos, sino que incrementen la fertilidad, mejorando las propiedades físicas del suelo y potenciando su función biofumigante contra los organismos patógenos (Bello et al., 2003). Climent et al. (1996), en términos ecológicos, también razonan sobre la devolución de los residuos a su punto de origen, cerrando así el ciclo de la materia de una forma natural.

Para García Izquierdo y Hernández (2004) la actividad metabólica que muestre un suelo se verá afectada por problemas de contaminación y descontaminación, relacionando dicha actividad con la posibilidad de degradación de compuestos que pueden haber sido adicionados antropogénicamente. Por ello es 
importante, especialmente en los últimos años, debido a la adición a los suelos de materiales orgánicos de diverso origen (como los ensayados como biofumigantes) conocer sus efectos y particularidades (aporte y generación de biomasa microbiana al suelo, contenidos a veces no deseables de contaminantes como metales pesados, etc.).

Durante los últimos años se ha incrementado el estudio del efecto supresivo de distintos restos de cosecha adicionados al suelo (Bailey y Lazarovits, 2003) así como su efecto biofumigante frente a enfermedades. No hay que olvidar que los factores químicos del suelo $(\mathrm{pH}$, contenido en calcio, las formas nitrogenadas, disponibilidad de nutrientes, etc.) tienen un papel fundamental en la expresión de determinadas enfermedades. Así, los pH alcalinos pueden ser responsables de la supresividad, como ocurre en su influencia sobre la marchitez bacteriana producida por $R$. solanacearum (Messiaen et al., 1995).

Otro concepto importante en el manejo de plantas (incluyendo sus restos) es el de alelopatía. Kim y Kil (2001) definen la alelopatía como un importante mecanismo mediante el cual determinadas sustancias producidas por una planta le proporcionan beneficios al provocar determinados efectos sobre otras. Estas sustancias se denominan aleloquímicos incluyendo la emisión de sustancias volátiles procedentes de exudados radiculares, de su descomposición, etc. Los suelos enfermos en agricultura podrían estar relacionados con la acumulación de estas sustancias, problema solucionado desde antiguo con la introducción de la rotación de cultivos en los sistemas agrícolas.

Kim y Kil (2001) estudiaron los efectos alelopáticos de algunas de estas sustancias liberadas de las plantas de tomate (Lycopersicon esculentum) que se recogen en la figura 2, información que se complementa con otros trabajos como los realizados por Ríos et al. (2008) sobre los gases liberados en la degradación de los carotenoides de tomate (tabla 6) o por Yu (1999) acerca de la supresión alelopática de la bacteria Ralstonia solanacearum en la combinación de cultivos de tomate con ajos chinos (Allium tuberosum). Los extractos acuosos de hojas, 
raíces y plantas enteras son altamente tóxicos conteniendo entre sus ácidos fenólicos: ácido tanico, hidroquinona, ácido p-hidroxibenzoico, ácido vanílico y ácido ferúlico. Entre las sustancias citadas, destaca la actividad antifúngica reconocida del xyleno estudiada por Abdel-Mallek et al. (1995) contra los hongos transmitidos por semilla en soja y que inhibe la producción de aflatoxinas por Aspergillus flavus, así como del citronellol contra Aspergillus flavus, Alternaria alternata, Colletotrichum capsici y Sclerotium rolfsii (Tripathi et al., 1985; Saikia et al., 2001) De los resultados obtenidos por los distintos grupos de investigación, se puede concluir que la alelopatía relacionada a plantas de tomate se debe a la presencia de sustancias químicas volátiles, sustancias que deberían ser todas estudiadas debido a su posible toxicidad contaminando suelos y perjudicando cultivos o a su capacidad de controlar los patógenos presentes en el mismo.

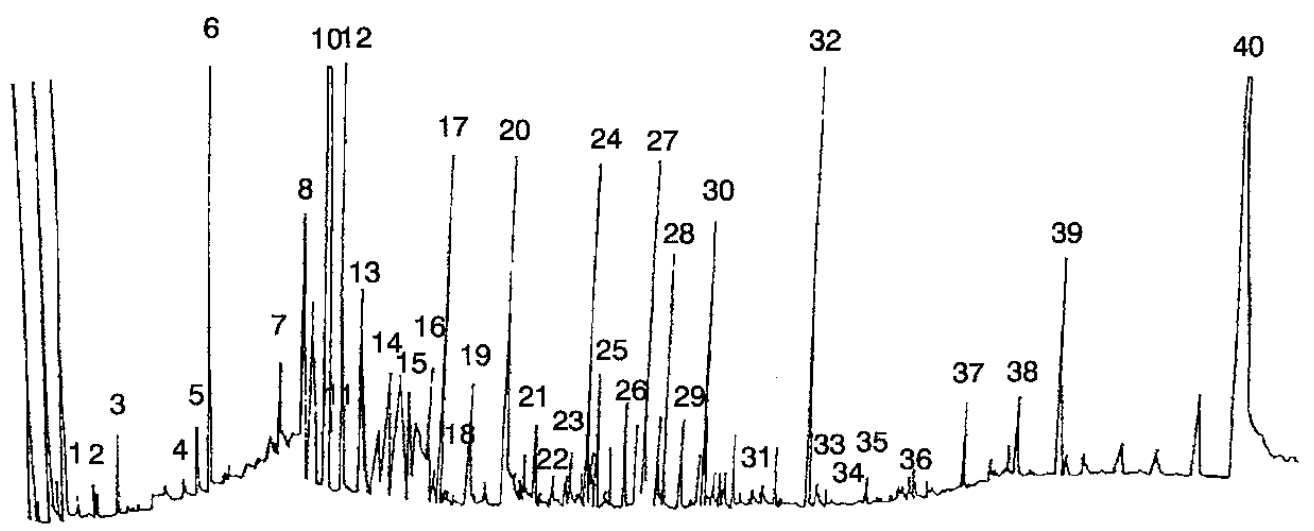

Keys to numbers: 1. Methylbenzene; 2. Decane; 3. Hexanal; 4. Dodecane; 5. iso-amyl alcohol; 6. trans-2-Hexenal; 7. 1-hexen-3-ol; 8. n-Hexanol; 9. cis-3-Hexenyl acetate; 10. cis-Hexen-1-ol; 11. Tetradecane; 12. trans2Hexen-1-ol; 13. Linalooloxide; 14. Acetic acid; 15. Pentadecane; 16. Benzaldehyde; 17. Linalool; 18. Hexadecane; 19. $\beta$-Caryophyllene; 20. Phenylacetaldehyde; 21. $\alpha$-Terpineol; 22. Methylbenzoate; 23. Ethylphenylacetate; 24. Methylsalicylate; 25. Geraniol; 26. Guaiacol; 27. Benzylalcohol; 28. 2-Phenylethylalcohol; 29. $\beta$-Caryophyllene epoxide; 31. Heneicosane; 32. Eugenol 33. Thymol; 34. Docosane; 35. Tricosine; 36. Tetracosane; 37 . Pentacosane; 38. Hexacosane; 39. Tetradecanoic acid; 40. Hexadecanoic acid. Components are listed only if their presence was confirmed by mass spectral analysis.

Figura 2. Cromatografía de gases de aceites esenciales en hojas de tomate

(Fuente: Kim y Kil, 2001) 
Tabla 6. Compuestos encontrados asociados a plantas de tomate (Fuente:

Ríos et al., 2008)

\begin{tabular}{|c|c|}
\hline COMPUESTO & CANTIDAD DETECTADA $^{\mathrm{a}}$ \\
\hline$\beta$-Citronellol ${ }^{\mathrm{b}}$ & 2,58 \\
\hline Tolueno $^{c}$ & 3,53 \\
\hline m-Xyleno ${ }^{c}$ & 14,9 \\
\hline 6-Methyl-3,5-heptadien-2-ona ${ }^{c}$ & 0,37 \\
\hline 6-Methyl-5-hepten-2-ona ${ }^{c}$ & 1,69 \\
\hline Ethanona, 1- (methylphenyl) ${ }^{\mathrm{c}}$ & 0,75 \\
\hline
\end{tabular}

Piedra Buena (2004) se refiere en su trabajo a la falta de información acerca del aporte de enmiendas orgánicas y restos de cultivo desde el punto de vista de los biominerales. Estos son minerales producidos por los seres vivos estando, los más frecuentes, formados por oxalato de calcio, carbonato cálcico y sílice amorfa. Los oxalatos abundan en angiospermas y gimnospermas, por lo que el estudio de los biominerales brindaría un nuevo aspecto de interés a los restos de cosecha que permanecen en el suelo. Estudios también recientes se refieren a la biofiltración, entendiendo como tal a la filtración de compuestos tóxicos en el suelo empleando microorganismos aeróbicos que se inmovilizan en partículas sólidas de los sustratos (turba, compost, etc.) dependiendo la adsorción de vapores perjudiciales (como los de tolueno) de la estructura física del suelo, de su $\mathrm{pH}$ y temperatura, así como de la humedad relativa en la fase gaseosa (Chen y Wu, 1998; Chiu et al., 2003; Singh et al., 2006). 


\subsubsection{Combinación de las técnicas expuestas}

El calentamiento del suelo ha demostrado tener efectos variables en el control de enfermedades y Katan $(1981,1983)$ sugería que algunas de las carencias de los tratamientos podrían compensarse mediante la combinación de distintas técnicas. Stapleton (2000) para la mejora de la eficacia de la solarización en caso de situaciones adversas como condiciones medioambientales marginales, presencia de organismos patógenos termotolerantes o que se distribuyen en el suelo a gran profundidad y con el objetivo añadido de minimizar la duración del tratamiento, aconseja combinar la solarización con otras técnicas que resulten compatibles. La solarización se puede combinar con otros métodos de control físico, químico y biológico (Stapleton et al., 2000).

Combinando enmiendas del suelo con la solarización se incrementa la efectividad contra patógenos y se reduce la cantidad de materia orgánica aplicada por hectarea (Bello et al., 1998; Gamliel y Stapleton, 1993).

Existen numerosos trabajos en los que se combinan las técnicas de desinfección química con la solarización y con el aporte de materias orgánicas, principalmente con materiales con actividad biofumigante, combinación que se puede denominar "biosolarización". Entre los beneficios de combinar enmiendas orgánicas y solarización se encuentra la reducción de las temperaturas necesarias para el control de las poblaciones de patógenos, ventaja especialmente importante en aquellas zonas donde la aplicación de la técnica quedaba restringida debido a condiciones ambientales adversas (Keinath, 1996).

Elad et al. (1980) comprobaron la eficacia del agente de control biológico Trichoderma harzianum contra Rhizoctonia solani y Verticillium dahliae combinando el agente biológico con la solarización y con tratamientos químicos (BM y metam-sodio) encontrando, además, que si bien la efectividad de los tratamientos solos contra los esclerocios del hongo Sclerotium rolfsii estaba cercana al 75\%, al combinar las técnicas el porcentaje se elevó hasta el 90\%. 
Otro ejemplo de la combinación de técnicas se muestra en el trabajo de Ramírez-Villapudua y Munnecke (1987; 1988). Estos autores indicaron que la población del hongo Fusarium oxysporum f.sp. conglutinans se redujo al combinar solarización con enmiendas de coles en una relación del 1\% empleando una lámina de PE transparente durante 4-6 semanas. De forma similar, Gamliel y Stapleton (1993) valoraron el efecto de los compuestos volátiles sobre los hongos patógenos del suelo Phytium ultimum y Sclerotium rolfsii usando restos de coliflor. Estos últimos autores justifican la combinación de técnicas indicando que la solarización es pasiva y dependiente de las condiciones meteorológicas, de modo que su integración con otros métodos de control físicos, químicos y biológicos mejoran la eficacia en el control de patógenos.

Quizás uno de los trabajos más completos y que aporta información muy interesante sobre el funcionamiento de las técnicas es el realizado por Chellemi et al. (1994) llevado a cabo en Florida estudiando los efectos de la solarización y fumigación, solas o combinadas, en la supervivencia de hongos $(F$. oxysporum f.sp. Radicis-lycopersici, F. oxysporum lycopersici, Phytophthora nicotianae o parasitica) y de la bacteria Ralstonia solanacearum. La solarización del suelo se realizó durante un periodo entre 32 y 49 días usando un film de PE de baja densidad y fotoselectivo. Como tratamiento químico se eligió la mezcla de BM y cloropicrina (67:33) y las temperaturas alcanzadas en el suelo fueron: suelo desnudo (sin cubrir) a profundidades de 5,15 y $25 \mathrm{~cm}$ se alcanzaron 43.8, 38.9 y $36.5^{\circ} \mathrm{C}$. Cuando se solarizó las temperaturas aumentaron a $49.5,46$ y $41.5^{\circ} \mathrm{C}$, respectivamente. Como resultados, la solarización sola supuso una disminución de Phytophthora y de la bacteria a profundidades de 25 y $15 \mathrm{~cm}$, respectivamente. Para los otros dos hongos, tras solarizar, sólo se observaron reducciones significativas en los 5 primeros $\mathrm{cm}$. Fumigando químicamente se redujeron significativamente las poblaciones de los hongos hasta a $35 \mathrm{~cm}$, en cambio para la bacteria el resultado fue muy variable. Esto es debido a que el BM es muy poco efectivo sin proporcionar un control duradero en las poblaciones bacterianas del 
suelo y, aunque la cloropicrina si que puede disminuir estas poblaciones, su efecto sobre $R$. solanacearum resulta errático. Hasta la fecha eran varios los trabajos que documentaban las reducciones de bacterias fitopatógenas empleando la solarización (Stapleton y DeVay, 1982a; Tjamos et al., 1992) así como los efectos sinérgicos entre solarización y enmiendas orgánicas o químicas que suponían reducciones en las poblaciones de determinados patógenos bacterianos. Gamliel y Stapleton (1993) procuraban resultados esperanzadores para el resto de enfermedades bacterianas, incluída la marchitez bacteriana producida por $R$. solanacearum. Chellemi et al. en 1997 realizaron un estudio similar en metodología al que realizaron en 1994 pero entonces los resultados en el control de la bacteria $R$. solanacearum no fueron los esperados justificándolos con una mala aplicación de la solarización ya que los plásticos se dispusieron en bandas estrechas quedando zonas sin cubrir totalmente y que actuaron como reservorio de patógenos. Además, la materia orgánica no se adicionó de una forma uniforme poniendo de manifiesto la importancia de la aplicación adecuada de los métodos de desinfección.

También contra hongos, Yücel (1995) comparó la efectividad de la solarización sola y combinada con una dosis reducida de BM $\left(40 \mathrm{~g} \mathrm{~m}^{-2}\right)$ en el control de Phytophthora capsici. Para este caso, resultan interesantes las condiciones en que se realizó la solarización, empleando una lámina de PE transparente y con un espesor de $0,03 \mathrm{~mm}$ durante 8 semanas facilitando datos de las temperaturas alcanzadas que fueron de 47 y $35^{\circ} \mathrm{C}$ a profundidades de 5 y 30 $\mathrm{cm}$, respectivamente. Comparando tratamientos los porcentajes de eficacia varían cuando se aplica solarización con bajas dosis de BM (del 55,8 al 68,9 \%) o sólo solarización (39,5-54\%). Sobre profundidades a las que la solarización resulta efectiva Mansoori y Jaliani (1996) indican que los propágulos de determinados hongos (Phytophthora drechsleri, Fusarium solani y Pythium aphanidermatum) se redujeron o se eliminaron totalmente a profundidades comprendidas entre 0 y 25 $\mathrm{cm}$ en suelos que permanecieron solarizados durante 30-60 días. 
Además del reconocido efecto para conrolar patógenos fúngicos o bacterianos, las técnicas de desinfección también han de ser capaces de controlar malas hierbas, evitando problemas de competencia, invasiones o evitando que actúen como reservorio de patóganos. Benlioglu et al. (2005) recogieron los resultados de las distintas técnicas ensayadas contra algunas malas hierbas. Entre los métodos ensayados se encontraba la solarización tanto sola como con estiércol de pollo (gallinaza), el BM, TeloDrip (1,3-D más cloropicrina) y solarizaciones de corta duración combinadas con dosis reducidas de metam-sodio y Telo-Drip. Todos los tratamientos proporcionaron un control efectivo contra Роа аппиа, Portulaca oleracea, Amaranthus retroflexus y Echinochloa crus-galli.

En España, la desinfección de suelos es una práctica habitual, y especialmente necesaria en las zonas de agricultura intensiva del sureste peninsular (Lacasa et al., 2002). Son muchos los resultados aportados durante los últimos años por los distintos grupos de investigación en busca de alternativas al BM algunos de lo cuales se muestran en la tabla 7, datos que se completan con los facilitados por Bello et al. (2003) que recogieron los distintos cultivos en los que, hasta la fecha, se había ensayado la biofumigación sola con resultados satisfactorios: fresas (en Andalucía y Valencia), pimientos (en Murcia y Castilla- La Mancha), cucurbitáceas (en Valencia, Castilla- La Mancha y Madrid), tomate (en Valencia y Canarias), viñedos (en Castilla-La Mancha), plataneras (en Canarias), zanahorias (Andalucía y Alicante), acelgas (en Madrid) y flor cortada, cítricos y árboles frutales (en Valencia)

En el caso de cultivos para los que se sigue solicitando el empleo de BM dentro de los "usos críticos" se encuentran el fresón y el pimiento, encontrando resultados favorables en la combinación de técnicas para reducir el empleo de productos químicos. Así, en la zona del Levante español Cebolla et al., en el año 1999 ensayaron las alternativas al BM donde, además de la mezcla de 1,3-D con cloropicrina en uno de los cultivos más delicados como es el fresón, también resultó efectivo el ensayo de biofumigación empleando solarización combinada 
con estiércol (biosolarización). Por su parte, López-Aranda (1999) en el sudeste español y para el mismo cultivo también obtuvo resultados satisfactorios con aplicaciones de 1,3-D con cloropicrina y con dazomet ensayando la solarización combinada con metam-sodio y con gallinaza como materia orgánica. Para el pimiento, Lacasa et al., (1999) y en la zona de Murcia encontraron que la mezcla 1,3-D con cloropicrina tiene el mismo rendimiento y eficacia en el control de patógenos que el BM. La biofumigación junto con solarización también resultó efectiva en los meses de más calor (desde julio a octubre) (Guerrero et al., 2004).

Durante los últimos años, los trabajos han continuado aportando nuevos datos sobre el comportamiento de las técnicas.

Cebolla y Maroto (2005) estudiaron distintas alternativas al BM para la desinfección de suelos centrando su trabajo en la zona de Valencia, en terrenos donde se cultiva chufa incluida dentro de un programa de rotación de cultivos. Como tratamientos ensayaron la mezcla 1,3-D con cloropicrina (65:35) y la técnica de solarización pero aprovechando restos de cultivos previos de coles que incorporaron al terreno, tratándose por tanto de una biosolarización. Las desinfecciones protegieron al suelo del ataque del hongo Sclerotinia sclerotiorum, aunque también matizaron que aunque la solarización tras el cultivo de coles supuso resultados excelentes (comparables a los de BM y sin los problemas que podría comportar el uso repetido de aportes de materia orgánica más rica en nitrógeno) tenía como inconveniente la larga duración del tratamiento y que no todas las rotaciones pueden incorporar un cultivo de col en primavera.

Debido a que el tratamiento de biofumigación con solarización ve aumentado su poder biocida con la repetición del tratamiento en el tiempo (Yélamos et al., 2002), una de las dudas que se intenta resolver está infundada en los peligros relacionados con la repetición de la desinfección y la adición continua de materia orgánica, que llevaría asociados problemas tanto de contaminación por metales pesados como por lixiviación de nitratos. Sobre el riesgo de acumulación de metales pesados, Flores et al. (2006) lo estudiaron en suelos sometidos a 
desinfecciones sucesivas combinando las técnicas de solarización con biofumigación concluyendo que tras seis años de repetición no se observó acumulación de los metales estudiados $(\mathrm{Cd}, \mathrm{Co}, \mathrm{Cu}, \mathrm{Cr}, \mathrm{Pb}, \mathrm{Ni}$ y $\mathrm{Zn})$ por lo que califican la combinación como de alternativa segura. Pascual et al. (2006) centraron sus investigaciónes en la dinámica del nitrógeno y su potencial contaminación por lixiviación de nitratos en la reiteración de biosolarización durante 5 años, en cultivos de pimiento en el sureste español, añadiendo importantes cantidades de materia orgánica. Comparando con suelos desinfectados químicamente con $\mathrm{BM}$, la cantidad de nitratos lixiviados para el suelo biosolarizado fue de $1453 \mathrm{mg}$ mientras que en el suelo desinfectado químicamente fue de $8010 \mathrm{mg}$.

También sobre reiteraciones Guerrero et al. (2006-b) compararon la eficacia de solarización y biosolarización aplicadas de forma consecutiva con un tratamiento químico, de modo que a partir del segundo año de biosolarización se logró una misma incidencia del patógeno en estudio (Meloidogyne incógnita) que en los tratamientos empleando un desinfectante de referencia. Desprendiéndose también de sus resultados que la biofumigación sola (en el caso considerado de un cultivo de pimiento y en la zona de Murcia) no reduce la incidencia de nematodos aunque se aplique al mismo suelo durante tres años, siendo necesario combinarla con solarizaciones. Resultados similares los obtuvieron Martínez et al. (2006-b) y en Cartagena, donde el cultivo de pimiento se reitera en el mismo suelo desde hace más de 25 años. En este caso, se reiteró la biosolarización durante 6 años para el control de hongos fitopatógenos y se comparó con los resultados del BM, igualándose la producción a partir del segundo año.

La mayoría de los efectos beneficiosos de la biofumigación han sido obtenidos empleando como biofumigantes estiércoles de cabra, oveja y vaca y residuos de arroz, setas, olivares, brassicas y jardines (Bello, 2004). Pero Regalado et al. (2006) aportan información sobre la incorporación de restos de cosecha de pimiento, calabaza y tomate indicando que la utilización de restos se considerará 
una alternativa viable siempre que se disponga de la cantidad adecuada de biomasa. Como resultado sorprende que los residuos que mejor funcionaron contra nematodos formadores de nódulos del género Meloydogyne fueron los de tomate. Del mismo modo, Piedra Buena et al. (2006, 2007) emplean contra estos nematodos la combinación de técnicas aprovechando los restos de pimiento y Vilaseca (2007) estudia el efecto biofumigante de restos de tomate en el control de los virus ToMV y PepMV así como del hongo Olpidium brassicae.

Tabla 7. Algunas alternativas al BM ensayadas durante los últimos años en España

\begin{tabular}{|c|c|c|c|c|}
\hline Técnica de desinfección & Cultivo & Patógeno(s) & Lugar & Referencia $^{d}$ \\
\hline $\begin{array}{c}\text { Solarización } \\
\text { Biosolarización }^{\text {a }} \\
\text { Metam-sodio }\end{array}$ & tomate & $\begin{array}{l}\text { Hongos y bacterias } \\
\text { (s.e. })^{\text {b }}\end{array}$ & Canarias & $\begin{array}{c}\text { Díaz-Hernández } \\
\text { et al. } 2002\end{array}$ \\
\hline Biofumigación & (s.e.) & Xiphinema index & $\begin{array}{l}\text { Castilla- } \\
\text { León }\end{array}$ & $\begin{array}{c}\text { Díez-Rojo et al. } \\
2002\end{array}$ \\
\hline $\begin{array}{l}\text { Biofumigación } \\
\text { Biosolarización }\end{array}$ & pimiento & $\begin{array}{c}\text { Phytophthora capsici } \\
\text { Meloidogyne incognita } \\
\text { Cyperus rotundus }\end{array}$ & $\begin{array}{l}\text { Sureste } \\
\text { español }\end{array}$ & $\begin{array}{l}\text { Martínez et al. } \\
2002\end{array}$ \\
\hline $\begin{array}{c}\text { BM } \\
\text { biosolarización }\end{array}$ & pimiento & $\begin{array}{c}\text { Hongos y bacterias } \\
\text { (s.e.) }\end{array}$ & Murcia & $\begin{array}{l}\text { Yélamos et al. } \\
2002\end{array}$ \\
\hline $\begin{array}{l}\text { Biofumigación } \\
\text { Biosolarización }\end{array}$ & fresón & (s.e.)- $\mathrm{p}^{\mathrm{c}}$ & Huelva & $\begin{array}{l}\text { Aguirre et al. } \\
2004\end{array}$ \\
\hline $\begin{array}{c}\text { Solarización } \\
\text { 1,3-Dicloropropeno }\end{array}$ & patata & Globodera spp. & Mallorca & $\begin{array}{l}\text { Alonso et al. } \\
2004\end{array}$ \\
\hline $\begin{array}{l}\text { Solarización } \\
\text { Biofumigación }\end{array}$ & olivo & Verticillium dahliae & Córdoba & $\begin{array}{c}\text { Bejarano- } \\
\text { Alcázar } \\
2004-a \\
2004-b\end{array}$ \\
\hline Biofumigación & melón & $\begin{array}{l}\text { Fusarium oxysporum } \\
\text { f.sp. radicis cucumerinum }\end{array}$ & Almería & $\begin{array}{l}\text { Boix et al. } \\
2004\end{array}$ \\
\hline
\end{tabular}




\begin{tabular}{|c|c|c|c|c|}
\hline Técnica de desinfección & Cultivo & Patógeno(s) & Lugar & Referencia $^{d}$ \\
\hline Biosolarización & escarola & $\begin{array}{c}\text { Fusarium spp. } \\
\text { Sclerotinia sclerotiorum }\end{array}$ & Valencia & $\begin{array}{c}\text { Cebolla } \text { et al. } \\
2004\end{array}$ \\
\hline $\begin{array}{l}\text { Biofumigación } \\
\text { Biosolarización }\end{array}$ & tomate & (s.e.)-p & Almería & $\begin{array}{c}\text { Cioduras et al. } \\
2004\end{array}$ \\
\hline $\begin{array}{c}\text { Solarización } \\
\text { Biofumigación } \\
\text { Metam-sodio }\end{array}$ & tomate & $\begin{array}{c}\text { Pyrenochaeta } \\
\text { lycopersici }\end{array}$ & Canarias & $\begin{array}{c}\text { Díaz-Hernández } \\
\text { et al. } 2004\end{array}$ \\
\hline $\begin{array}{c}\text { Telone } \mathrm{C}-35 \\
\text { BM }\end{array}$ & tomate & Meloidogyne spp. & Murcia & $\begin{array}{c}\text { Lacasa } \text { et al. } \\
2004\end{array}$ \\
\hline $\begin{array}{l}\text { Biofumigación } \\
\text { Biosolarización }\end{array}$ & fresón & Flora arvense & Huelva & $\begin{array}{c}\text { López-Martínez } \\
\text { et al. } \\
2004\end{array}$ \\
\hline $\begin{array}{c}\text { Biosolarización } \\
\text { BM }\end{array}$ & pimiento & Fusarium solani & $\begin{array}{c}\text { Sureste } \\
\text { peninsular }\end{array}$ & $\begin{array}{c}\text { Martínez et al. } \\
\text { 2004-a }\end{array}$ \\
\hline
\end{tabular}

\section{B.M.}

Cloropicrina

Cloropicrina con 1,3-D

Otros productos con

escasa actividad

fungicida
Microbiota fúngica:

Fusarium spp.

Penicillium

Aspergillus

Alternaria
Murcia $\quad$ Martínez et al.

Alicante 2004-b

Biofumigación

Biosolarización

Meloidogyne

Piedra Buena

Tratamientos químicos

Microbiota fúngica:

Biofumigación

Verticillium dahliae

Reyes et al.

Solarización

olivo

Fusarium

Pithyum

2004-a

Biosolarización

Phytophthora

\begin{tabular}{ccccc}
\hline $\begin{array}{c}\text { Biofumigación } \\
\text { Pseudomonas sp. }\end{array}$ & Remolacha & Rhizoctonia solani & Burgos & $\begin{array}{c}\text { Sacristán } \text { et al. } \\
\text { azucarera }\end{array}$ \\
\hline Biofumigación & pimiento & Phytophthora capsici & Almería & Santos et al. 2004 \\
\hline
\end{tabular}




\begin{tabular}{|c|c|c|c|c|}
\hline Técnica de desinfección & Cultivo & Patógeno(s) & Lugar & Referencia $^{d}$ \\
\hline Biosolarización & tomate & $\begin{array}{l}\text { Fusarium oxysporum } \\
\text { f.sp. radicis lycopersici }\end{array}$ & Almería & $\begin{array}{l}\text { Segura et al. } \\
2004\end{array}$ \\
\hline $\begin{array}{c}\text { Biosolarización } \\
\text { BM } \\
\text { Solarización con metam- } \\
\text { sodio } \\
\text { Cloropicrina }\end{array}$ & escarola & $\begin{array}{l}\text { Fusarium oxysporum } \\
\text { Flora arvense }\end{array}$ & Valencia & $\begin{array}{l}\text { Cebolla y } \\
\text { Maroto } \\
2005\end{array}$ \\
\hline $\begin{array}{c}\text { Biofumigación } \\
\text { 1,3-D }\end{array}$ & $\begin{array}{c}\text { hortícolas } \\
\text { varios }\end{array}$ & Meloidogyne spp. & Madrid & $\begin{array}{l}\text { Arranz et al. } \\
2006\end{array}$ \\
\hline $\begin{array}{l}\text { Biofumigación, } \\
\text { solarización } \\
\text { biofungicidas }\end{array}$ & tomate & Phytophthora infestans & $\begin{array}{c}\text { Patacao } \\
\text { (Portugal) }\end{array}$ & $\begin{array}{l}\text { Barrau et al. } \\
\quad 2006\end{array}$ \\
\hline $\begin{array}{l}\text { Biofumigación } \\
\text { Biosolarización } \\
\text { Metam-sodio }\end{array}$ & alcachofa & Verticillium dahliae & Catellón & $\begin{array}{c}\text { Berbegal et al. } \\
2006\end{array}$ \\
\hline $\begin{array}{l}\text { Biosolarización } \\
\text { Biofumigación }\end{array}$ & pimiento & Meloidogyne spp. & Murcia & $\begin{array}{c}\text { Guerrero et al. } \\
2006 \mathrm{~b}\end{array}$ \\
\hline $\begin{array}{c}\text { Biosolarización } \\
\text { BM }\end{array}$ & pimiento & Microbiota fúngica & Murcia & $\begin{array}{c}\text { Martínez et al. } \\
\text { 2006b }\end{array}$ \\
\hline Biofumigación & tomate & Meloidogyne spp. & Canarias & $\begin{array}{c}\text { Regalado et al. } \\
2006\end{array}$ \\
\hline Biofumigación & (s.e.) & Phytophthora spp. & Sevilla & $\begin{array}{c}\text { Romero et al. } \\
2006 \mathrm{a}\end{array}$ \\
\hline $\begin{array}{l}\text { Biofumigación } \\
\text { Biosolarización }\end{array}$ & tomate & $\begin{array}{c}\text { ToMV } \\
\text { PepMV } \\
\text { Olpidium brassicae }\end{array}$ & Valencia & $\begin{array}{l}\text { Vilaseca } \\
2007\end{array}$ \\
\hline
\end{tabular}

${ }^{a}$ Se considera biosolarización a la combinación de biofumigación y solarización

${ }^{\mathrm{b}}$ (s.e.): Sin especificar

c (s.e)-p: no se especifica y el estudio se centra en la producción del cultivo

${ }^{\mathrm{d}}$ Referencias ordenadas cronológicamente 


\subsubsection{Agentes de control biológico}

El control biológico consiste en el empleo de organismos antagonistas y ha sido ampliamente estudiado durante las últimas décadas como alternativa a la aplicación de los pesticidas para el control de patógenos (Baker, 1987; Becker y Schwinn, 1993; Deacon y Berry, 1993; Piedra Buena, 2004; Potera, 1994). La eficacia de los agentes de control biológico varía bajo diferentes condiciones de cultivo y su aplicación no ha sido muy satisfactoria en suelos con alta biodiversidad pero su uso se considera de interés para la recuperación de aquellos suelos afectados por el uso intensivo de agroquímicos que tienen baja o nula biodiversidad. Según Hoitink y Boehm (1999) el control biológico de amplio espectro requiere de la introducción o presencia de fuentes edáficas de nutrientes orgánicos en el suelo para alimento de los agentes de biocontrol. El nivel de descomposición de la materia orgánica afecta de forma crítica a la tasa microbiana, poblaciones y a la actividad de los agentes de biocontrol. Competición, antibiosis, parasitismo y la resistencia inducida se ven todas afectadas. Las enmiendas orgánicas como estiércoles en verde, estiércoles estables y el compost sirven como fuente de nutrientes e incluso puede ofrecer una oportunidad para introducir y establecer en el suelo agentes de biocontrol específicos. La cantidad y calidad de la materia orgánica son críticas para la supervivencia y eficacia de los agentes de biocontrol como por ejemplo de las bacterias Pseudomonas spp. y Pantoea spp.

Al final de la década de los 80 existía la opinión de que el control biológico podía tener un papel importante en la agricultura del futuro y muchas empresas comenzaron a implantar programas de desarrollo de agentes de biocontrol como productos comerciales y actualmente algunos de estos agentes ya están disponibles como preparados comerciales como el QUANTUM 4000 de Bacillus subtilis o SoilGard de Gliocladium (Berger et al., 1996; Piedra Buena, 2004; Weller 1988). Este interés renovado es, en parte, una respuesta a la preocupación pública respecto a los daños asociados a la aplicación de pesticidas químicos. 


\subsubsection{Principales agentes de control biológico}

Los métodos de control biológico incluyen a microorganismos antagonistas, que, establecidos en el lugar de la infección previamente al ataque del patógeno, pueden prevenir la infección o colonizar tejidos invadidos deteniendo el desarrollo de la enfermedad (González et al., 2004).

La presencia de organismos antagonistas de patógenos del suelo ha dado origen al concepto de suelos supresivos pudiendo ser la supresividad natural e inducida así como general y específica (Tello, 1988; Diánez 2005). El concepto fue ampliado a sistemas supresivos incluyendo el ambiente y las plantas (Tello y Rodríguez Molina, 1998). El aislamiento de antagonistas a partir del suelo supresivo es una alternativa para el manejo de patógenos del suelo. Un aspecto de importancia al introducir un agente de control biológico al suelo es que para que éste pueda establecerse necesita encontrar un "nicho ecológico" que no esté ocupado (Rodríguez-Kábana, 1998) y/o introducirse en cantidades muy altas para poder competir con los organismos autóctonos.

Los microorganismos que crecen en la rizosfera son ideales para emplearse como agentes de biocontrol ya que ésta proporciona una barrera de defensa para las raíces contra el ataque de los patógenos. En los últimos años se ha estudiado, principalmente, el efecto de bacterias capaces de proporcionar un control sustancial de la enfermedad en el campo y, en ocasiones, el control se consigue por medio de estas en suelos supresivos (Weller, 1988). Uno de los efectos beneficiosos observados de forma frecuente es el estímulo del crecimiento de las plantas por la acción de las rizobacterias, de aquí el nombre que reciben de rizobacterias promotoras del crecimiento vegetal, del inglés "Plant Growth Promoting Rhizobacteria, PGPR” (Piedra Buena, 2004, Kloepper, 1998, Weller, 1988). El término rizobacteria fue acuñado para las bacterias con la capacidad de colonizar las raíces de forma agresiva (Schroth y Hancock, 1981; 1982). 
Las bacterias que muestran o que se piensa que tienen poder de biocontrol se encuentran en muchos géneros: Actinoplanes, Agrobacterium, Alcaligenes, Amorphosporangium, Arthrobacter, Azotobacter, Bacillus, Enterobacter, Erwinia, Flavobacterium, Hafnia, Micromonospora, Pseudomonas, Pasteuria, Rhizobium y Bradyrhizobium, Serratia, Streptomyces y Xanthomonas (Weller, 1988).

El gran ejemplo de un agente de biocontrol bacteriano es el de Agrobacterium radiobacter cepas 84 y 1026 (K-84 y K-1026), que figuran entre los microorganismos con cierta introducción en el mercado comercializándose en varios países para el control de la enfermedad causada por A. tumefaciens (Barres, 2006).

Bacillus spp. ha sido probado en una amplia variedad de especies, así Bacillus subtilis puede mejorar el crecimiento de las plantas al suprimir los patógenos no parásitos de las raíces o mediante la producción de sustancias biológicamente activas (Broadbent et al., 1977). Bacillus brevis produce gramacidin S con alto poder "in vitro" contra Botrytis cinerea y Bacillus subtilis CL27 produce dos antibióticos con alta actividad contra el mismo patógeno (Leifert et al., 1995). De gran interés es el Bacillus subtilis A13 que inhibe "in vitro" varios patógenos de las plantas mejorando el crecimiento de las mismas en suelos desinfectados con vapor de agua o en los naturales. Desde 1983 B. subtilis A13 ha sido comercializado como tratamiento en los cultivos de cacahuetes bajo el nombre de QUANTUM-4000 (Gustafson, Dallas Texas; B.L. Kirkpatrick). Según Berger et al. (1996) Bacillus subtilis Cot 1 previene las enfermedades causadas por Phytophthora y Pithyum en microplantas de Astilbe, Photinia y Hemerocallis. Reinoso (2007a; 2007b) aisló del suelo distintas cepas pertenecientes a las especies Bacillus subtilis, Paenibacillus polimixa y Bacillus licheniformis determinando su efecto antagónico frente a Alternaria solani y Rhizoctonia solani. Existe una tendencia a usar Bacillus y otros géneros afines, como Brevibacillus y Paenibacillus, para la inducción de resistencias sistémicas en plantas que supone una protección efectiva frente al ataque de hongos fitopatógenos causantes de 
enfermedades foliares (Silva et al., 2004). Algunas especies de estos tres géneros producen varios tipos de metabolitos, algunos con actividad antifúngica, como es el caso de los compuestos de naturaleza peptídica y lipopeptídica (Souto et al., 2004) y otros volátiles con enzimas quitinolíticas (Edwards y Seddon, 2001; Földes et al., 2000; Montealegre et al., 2003; Sadfi et al., 2001).

En estudios realizados por otros autores se emplea el suelo para obtener aislados de estos géneros, ya que, a pesar de la ubicuidad de estos microorganismos el suelo es su principal hábitat (Garbeva et al., 2003). Reinoso et al. (2007-a; 2007b) determinaron el posible efecto antagónico "in vitro" de Bacillus, Brevibacillus y Paenibacillus aislados de muestras de suelo frente a las bacterias Pectobacterium carotovorum, P. atrosepticum y Dickeya chrysanthemi y frente a los hongos indicados anteriormente, Rhizoctonia y Alternaria solani. En este caso obtuvieron que las cepas más prometedoras para el control biológico corresponden a las especies Bacillus subtilis, Bacillus licheniformis, Paenibacillus polimixa, Brevibacillus brevis y Brevibacillus laterosporus. Este último microorganismo también fue estudido por Justo de Oliveira (2004) aislado de suelos brasileños.

Respecto a las Pseudomonas spp. también tienen gran importancia como agentes de biocontrol (Nagarajkumar et al., 2005). En 1978, Burr et al. indicaron que razas de $P$. fluorescens y $P$. putida aplicadas a las semillas mejoraban el posterior crecimiento de patatas ampliándose después a otros cultivos como la caña de azúcar o el rábano. En 1982, Schroth y Hancock continuaron estos estudios confirmando los resultados para los mismos cultivos. Estas razas y similares son las primeras que recibieron el nombre de PGPR.

Singh et al. (1999) encontraron que las cepas de bacterias quitinolíticas Paenibacillus sp. 300 y Streptomyces sp. 385, eran capaces de suprimir la enfermedad causada por Fusarium oxysporum f.sp. cucumerinum en cultivos de pimiento y experimentaron mezclando ambas cepas, obteniendo los mejores resultados. 
También se han obtenido resultados satisfactorios en el empleo de Coniothyrium minitans contra Sclerotinia sclerotiorum y Pseudomonas fluorescens o C. globosum contra Botrytis cinerea (Berger et al., 1996; Köhl et al., 1995).

Los hongos Coniothyrium y Microsphaeropsis están distribuidos ampliamente y se aislan de forma común asociados a diferentes hábitats, recibiendo especial atención al considerasrse agentes de biocontrol y por su producción de compuestos con capacidad antibiótica (Verkley et al., 2004).

Coniothyrium minitans Campbell y Coniothyrium pyrinum (Phoma pomorum var. pomorum Thüm) se han identificado como potentes agentes de biocontrol. Conner et al. (2000) identificaron la eficacia del hongo Phoma pomorum contra la mala hierba Cynoglossum officinale, causante de la muerte prematura de hojas y de su defoliación.

C. minitans, ha sido descrito como micoparásito que combate satisfactoriamente enfermedades causadas por hongos patógenos formadores de esclerocios como S. sclerotiorum (Gerlagh et al., 1999; Jones et al., 2004; McQuilken et al., 1997) y S. minor (Partridge et al., 2006; Rabeerdran et al., 2006). Para un amplio rango de cultivos ha demostrado tener una mayor eficacia que los fungicidas en distintos ensayos realizados tanto en campo como en invernadero suprimiendo por completo la producción de apotecios y esclerocios. Los investigadores sugieren que la reducción del inóculo del patógeno es la clave del biocontrol.

Durante los últimos años se han aislado varios compuestos procedentes de distintas especies de Coniothyrium estudiándose su actividad (Kock et al. 2007) y algunos autores (Ren et al., 2007) sugieren que la degradación del ácido oxálico por parte del hongo $C$. minitans puede anular el efecto del $\mathrm{pH}$ condicionado por este ácido y mejorar su micoparasitismo sobre S. sclerotiorum estimulando la producción y/o actividad del enzima $\beta$-1,3-glucanasa por parte del agente de biocontrol. 
El efecto de Conitohyrium sobre las ascosporas de Sclerotinia spp. podría ser el mismo contra otros hongos que también produzcan estas estructuras como Mycosphaerella brassicicola.

El género Coniothyrium está relacionado con Microsphaeropsis diferenciándose por la presencia de anélidas (Carisse y Bernier, 2002). El Bassam et al. (2002) propusieron que Microsphaeropsis ochracea (Carisse y Bernier) podía combatir al patógeno Venturia inaequalis mediante la producción de compuestos líticos. Butler et al. (2005) añadieron que la pared celular de melanina presente en los hongos fitopatógenos puede incrementar el efecto inhibitorio de los hongos antagonistas. Son numerosos los estudios que intentan optimizar la aplicación de aislados de Microsphaeropsis en técnicas de biocontrol como las ensayadas contra la sarna del manzano (Carisse et al., 2000; Carisse y Bernier, 2002; Carisse y Rolland, 2004).

M. ochracea fue capaz de inhibir "in vitro" la producción de ascosporas de Gibberella zeae (Bujold et al., 2001). Carisse et al. (2001) propusieron que como tanto $V$. inaequalis como G. zeae producen ascosporas en estructuras con melanina (pseudotecios y peritecios), se supone que Microsphaeropsis sp. podría inhibir la producción y germinación de otras estructuras fúngicas con melaninas, como son los esclerocios. Así, evaluaron el efecto de Microsphaeropsis sp. en el control de Rhizoctonia solani reduciéndose la germinación de esclerocios. Además, estos mismos autores indicaron que los mecanismos involucrados en este antagonismo fueron la antibiosis y el micoparasitismo.

Del mismo modo, también se estudió el efecto de $M$. ochracea en la producción de esclerocios y conidios de Botrytis squamosa (Carisse et al., 2006). En este caso, el número de conidios producidos se redujo en ensayos en campo en cultivos de cebollas donde $M$. ochracea sólo colonizó hojas senescentes o necróticas reduciendo la producción de conidios.

En la tabla 8 se recogen algunos de los trabajos empleando organismos antagonistas realizados en España durante los últimos años. 
Tabla 8. Aplicación de control biológico en algunas investigaciones realizadas en España.

\begin{tabular}{|c|c|c|c|}
\hline Control biológico & Cultivo & Patógeno(s) & Referencia $^{d}$ \\
\hline $\begin{array}{c}\text { Pseudomonas fluorescens } \\
\text { Pantoea agglomerans }\end{array}$ & fresón & Phytophthora cactorum & $\begin{array}{c}\text { Agustí et al. } \\
\text { 2006-a }\end{array}$ \\
\hline $\begin{array}{c}\text { Pseudomonas fluorescens } \\
\text { Pantoea agglomerans }\end{array}$ & Prunus sp. & Meloidogyne javanica & $\begin{array}{c}\text { Agustí et al. } \\
\text { 2006-b }\end{array}$ \\
\hline $\begin{array}{c}\text { Varios fagos aislados de } \\
\text { agua de río }\end{array}$ & tomate & Ralstonia solanacearum & $\begin{array}{c}\text { Álvarez et al. } \\
2006\end{array}$ \\
\hline $\begin{array}{c}\text { Trichoderma harzianum } \\
\text { con solarización y restos } \\
\text { de coles }\end{array}$ & tomate & $\begin{array}{c}\text { Pyrenochaeta } \\
\text { lycopersici }\end{array}$ & $\begin{array}{l}\text { Díaz-Hernández } \\
\text { et al. } 2006\end{array}$ \\
\hline Pantoea agglomerans & frutos varios & $\begin{array}{c}\text { Rhizopus stolonifer } \\
\text { Botrytis cinerea } \\
\text { Penicillium expansum } \\
\text { Monilia laxa } \\
\text { Colletotrichum acutatum }\end{array}$ & $\begin{array}{c}\text { Francés et al. } \\
2006\end{array}$ \\
\hline $\begin{array}{c}\text { Pseudomonas spp. } \\
\text { Bacillus spp. }\end{array}$ & melón & Podosphaera fusca & $\begin{array}{c}\text { García-Gutiérrez } \\
\text { et al. } 2006\end{array}$ \\
\hline $\begin{array}{l}\text { Pseudomonas } \\
\text { fluorescentes } \\
\text { Bacillus cereus } \\
\text { Bacillus subtilis }\end{array}$ & aguacate & Rosellinia necatrix & $\begin{array}{c}\text { González- } \\
\text { Sánchez et al. } \\
2006\end{array}$ \\
\hline Pseudomonas fluorescens & $\begin{array}{l}\text { Aguacate } \\
\text { tomate }\end{array}$ & $\begin{array}{c}\text { Rosellinia necatrix } \\
\text { Fusarium oxysporum }\end{array}$ & $\begin{array}{c}\text { Martín -Pérez et } \\
\text { al. } 2006\end{array}$ \\
\hline Pantoea agglomerans & frutos varios & $\begin{array}{c}\text { Penicillium expansum } \\
\text { Monilia laxa } \\
\text { Rhizopus stolonifer }\end{array}$ & $\begin{array}{l}\text { Moreno et al. } \\
2006\end{array}$ \\
\hline Pseudomonas spp. & aguacate & Rosellinia necatrix & Pliego et al. 2006 \\
\hline
\end{tabular}




\begin{tabular}{|c|c|c|c|}
\hline Control biológico & Cultivo & Patógeno(s) & Referencia $^{d}$ \\
\hline $\begin{array}{c}\text { Trichoderma spp. Con } \\
\text { solarización }\end{array}$ & fresa & $\begin{array}{c}\text { Colletotrichum spp. } \\
\text { Phytophthora cactorum }\end{array}$ & Porras et al. 2006 \\
\hline $\begin{array}{l}\text { Empleo de oxilipinas } \\
\text { naturales y artificiales }\end{array}$ & geranios & $\begin{array}{c}\text { Botrytis cinerea } \\
\text { Xanthomonas campestris }\end{array}$ & $\begin{array}{c}\text { Ramos-Solano et } \\
\text { al. } 2006\end{array}$ \\
\hline Trichoderma harzianum & tabaco & Rhizoctonia solani & $\begin{array}{c}\text { Rincón et al. } \\
2006\end{array}$ \\
\hline Bacillus subtilis & cucurbitáceas & Podosphaera fusca & $\begin{array}{l}\text { Romero et al. } \\
2006 \mathrm{~b}\end{array}$ \\
\hline Penicillium oxalicum & tomate & $\begin{array}{c}\text { Fusarium oxysporum } \\
\text { f.sp. lycopersici }\end{array}$ & $\begin{array}{c}\text { Sabuquillo et al. } \\
2006\end{array}$ \\
\hline Trichoderma asperellum & tomate & $\begin{array}{c}\text { Fusarium oxysporum } \\
\text { Rhizoctonia solani }\end{array}$ & $\begin{array}{l}\text { Trillas et al. } \\
2006\end{array}$ \\
\hline Pantoea agglomerans & cítricos & $\begin{array}{c}\text { Penicillium digitatum } \\
\text { Penicilliumitalicum }\end{array}$ & Usall et al. 2006 \\
\hline Bacillus subtilis & cucurbitáceas & $\begin{array}{c}\text { Xanthomonas campestris } \\
\text { Erwimia carotovora }\end{array}$ & $\begin{array}{l}\text { Zeriouh et al. } \\
2006\end{array}$ \\
\hline
\end{tabular}

\subsubsection{Modos de acción y aplicación}

El control biológico depende del umbral de establecimiento de la población de microorganismos tanto en el material vegetal como en el suelo. Entre los muchos factores edáficos que influyen se incluyen la temperatura (Loper et al., 1985; Weller y Cook, 1983), la humedad del suelo (Burr et al., 1978; Campbell y Clor, 1975; Dupler y Baker, 1984; West et al., 1985), pH (West et al, 1985), el establecimiento de los agentes de control y su interacción con los patógenos (Weller, 1988).

En el caso de bacterias, la manera en que se cultivan y procesan afectará a su viabilidad y tolerancia a las condiciones adversas. Son varias las razones para la obtención de resultados inconsistentes dependiendo de multitud de factores debido 
a las complejas interacciones entre huésped, patógeno, antagonista y las condiciones ambientales. En la justificación de resultados variables siempre se manejan tres posibilidades: la pérdida de competencia ecológica (se define como la capacidad de una bacteria para competir y sobrevivir en la naturaleza), ausencia del patógeno seleccionado como "blanco" o interferencia de otros patógenos "no blancos" y una variable colonización de la rizosfera.

Respecto a la supresión de los patógenos Weller (1988) indica la acción de cuatro mecanismos: 1) Competición por el sustrato y exclusión de nichos; 2) Sideróforos que son compuestos que se producen en condiciones de hierro limitante, con bajo peso molecular y que actúan como agentes quelantes, con gran afinidad por el Fe III. Koeppler et al. (1980a) fueron los primeros en demostrar la importancia de la producción de sideróforos como mecanismo de control biológico. Como estos secuestran el Fe III limitan su disponibilidad para los patógenos suprimiendo su crecimiento (Díaz et al., 2002); 3) Producción de antibióticos que juegan el papel más importante en la supresión de la enfermedad y 4) Resistencia inducida.

Butler et al. (2005) estudiaron un modo de acción específico mediante el que los agentes de biocontrol incluyendo hongos, bacterias y nemátodos pueden limitar la acumulación y persistencia de patógenos mediante la degradación de sus melaninas o inhibiendo su producción. Muchos hongos producen estas melaninas, que son pigmentos asociados a la patogénesis fúngica (Islas-Flores, 2006) y que confieren a sus esporas o esclerocios una persistencia medioambiental. Son numerosos los artículos que informan sobre el papel de las melaninas en la efectividad de algunos antagonistas como Mycosphaerella spp. (Islas-Flores et al., 2006; Mehrabi y Kema, 2006; Stierle et al., 1991).

La efectividad del control biológico también dependerá del ambiente en el que se realice. El ambiente de las superficies foliares difiere en muchos aspectos del suelo, dos hábitats donde se han aplicado las técnicas de biocontrol. En el suelo 
las condiciones ambientales pueden variar entre lugares, pero son relativamente estables en el tiempo en comparación con las rápidas fluctuaciones de la filosfera.

Köhl y Fokkema (1998) estudiaron el control biológico de patógenos foliares diferenciando entre patógenos necrotróficos y biotróficos ya que uno de los mecanismos más importantes de control como es la competición por los nutrientes sólo es aplicable a los patógenos necrotróficos. Estos autores centran sus investigaciones en el control de hongos fitopatógenos, explicando su mecanismo de acción en los tejidos foliares afectados. Considerando el control biológico se diferencian tres estrategias: 1) infección dirigida a las esporas no germinadas o en germinación como el estado inicial de la fase patogénica del ciclo de vida del patógeno. 2) Supresión bacteriana de la colonización del micelio y de la supervivencia del patógeno en su estado saprofítico en los tejidos necróticos de las plantas como fuente inicial o inóculo secundario responsable de nuevos ciclos de infección. 3) Degradación microbiana de esclerocios como inóculo inicial en las siguientes fases de crecimiento.

El desarrollo tanto del patógeno y de los agentes de control biológico en la filosfera está determinado por varios factores abióticos como la disponibilidad de nutrientes, temperatura, humedad, radiaciones UV y la deposición de agroquímicos en la superficie foliar. En esta zona los mecanismos involucrados en el antagonismo son de nuevo la competición por los nutrientes, antibiosis y micoparasitismo. Acerca de la antibiosis, los microorganismos productores de antibióticos fueron los primeros en considerarse en la búsqueda de agentes de biocontrol ya que su selección puede realizarse con poco esfuerzo empleando medios de cultivo donde observar zonas de inhibición.

La utilización de antibióticos foliares está limitada por distintos factores. Así, para resultar efectivos tienen que estar presentes de forma continuada con la superficie protegiendo a las hojas de nuevas infecciones, pero los antibióticos, generalmente, no son altamente estables bajo condiciones de campo. No hay que olvidar que las poblaciones de antagonistas deben estar presentes de forma 
continua y en densidades suficientemente altas para producir nuevos antibióticos (Köhl y Fokkema, 1998). Estos autores también indican como factor limitante la aparición de resistencias por parte de algunos patógenos como la desarrollada por Botrytis cinerea a Bacillus subtilis en cultivos de Astilbe.

Acerca del micoparasitismo este se define para muchas interacciones hongo-hongo. El parasitismo depende del estrecho contacto entre el antagonista y el hospedador, de la secreción de enzimas y del crecimiento activo del parásito en el hospedador. El desarrollo del micelio de los patógenos necrotróficos también puede controlarse por micoparásitos. Así, el micoparásito Coniothyrium minitans penetra dentro del micelio de Sclerotinia sclerotiorum que se colapsa y se necrosa (Adams, 1990; Whipps y Gerlagh, 1992). También el antagonista Limonomyces roseipellis tiene actividad quitinolítica y puede emplearse contra Pyrenophora triticirepentis en restos de cultivo de trigo (Pfender, 1988). El-Tarabily et al. (2000) estudiaron la supresión del crecimiento de S. minor por parte de distintas bacterias con altos niveles de quitinasa así como de algunos actinomicetos, obteniendo los mejores resultados con los hongos C. minitans y Sporidesmium sclerotivorum.

Dentro de los mecanismos de acción cabe indicar la diferencia entre alelopatía y antibiosis así como la combinación de técnicas. Según Barres (2006) en el concepto de alelopatía sobre patógenos y parásitos de las plantas se puede considerar el efecto pernicioso, directo o indirecto, ejercido sobre aquellos por la producción de compuestos químicos liberados al medio por parte de algunos vegetales. Los residuos en descomposición presentan interés por la presencia en los mismos de compuestos aleloquímicos indicando entre los más comunes acetogeninas, alcaloides, fenoles, fenilpropanos, flavonoides, poliacetilenos y terpenoides. Respecto a la antibiosis, se entiende como un antagonismo influido por metabolitos de origen microbiano, entre los que se encuentran agentes líticos, enzimas, compuestos volátiles y otras sustancias tóxicas. 
La combinación de los agentes de control biológico con otras técnicas como las rotaciones de cultivos, la esterilización parcial del suelo mediante solarización, enmiendas orgánicas y uso de fungicidas, se realiza para lograr resultados equivalentes a los fungicidas de síntesis, incluyendo el BM (Barres, 2006; Jacobsen y Backman, 1993; Kloepper, 1998). Por ejemplo, González et al. (2004) y Santander et al. (2003) investigaron el control de los bioantagonistas Paenibacillus lentimorbus, Trichoderma harzianum y Trichoderma polysporum frente a distintos hongos fitopatógenos. Los aplicaron solos y en combinación con solarización y con BM, resultando siempre la combinación con solarización la técnica más efectiva.

\section{Patógenos ensayados}

\subsection{Ralstonia solanacearum}

Ralstonia solanacearum (E. F. Smith 1986) Yabuuchi et al. 1995, se considera en muchos países como una de las grandes amenazas para varios cultivos pudiendo afectar a más de doscientas especies de plantas en las zonas tropicales, subtropicales y regiones templadas de todo el mundo (Haywood, 1991). Sus huéspedes principales son los cultivos de tomate, patata, tabaco, cacahuete y bananas (Flavier et al., 1997; Caruso, 2005) teniendo la capacidad de causar marchitamientos (Nesmith y Jenkins, 1983). Se propaga con el agua de riego, en asociación con los restos de cultivo, herramientas contaminadas y en los movimientos de suelos infectados.

En Europa se considera patógeno de cuarentena incluyéndose en la lista A2 por la EPPO, con especial atención a la raza 3 responsable de las enfermedades de "brown rot" (podredumbre marrón) en patata y "bacterial wilt" (marchitamiento bacteriano) en tomate (OEPP/EPPO, 2004a; 2004b). Actualmente se encuentra ampliamente dispersa por todos los continentes proponiéndose como posible origen de $R$. solanacearum poblaciones de bacterias saprofitas, basándose en la habilidad de esta especie de sobrevivir en dicho hábitat (Buddenhagen y 
Kelman, 1964). En la figura 3 se muestra la distribución del patógeno. Aunque en España no aparece, se considera como "Absent, pest no longer present" (patógeno que estuvo presente no hace mucho tiempo) (OEPP/EPPO, 2006).

Atendiendo a sus posibles huéspedes y a la capacidad de utilizar azúcares y oxidar alcoholes, esta especie está clasificada en cinco razas y cinco biovares, respectivamente (Caruso, 2005; French et al., 1995; Hayward et al., 1990; He et al., 1983). Esta clasificación se muestra en la tabla 9.

Algunos autores (Horita y Tsuchiya, 2001) consideran 5 razas y 6 biovares y dos divisiones: la división "Americanum" que contiene a los biovares 1 , 2 y N2 y la división "Asiaticum" con los biovares 3, 4 y 5, de modo que las divisiones son de tipo geográfico, pero esta taxonomía todavía se considera en transición y concordaría con lo expuesto por otros autores (Poussier et al., 2000) en la existencia de dos divisiones en las especies de Ralstonia que representarían a subdivisiones, concluyendo que la designación de "Americanum" y "Asiaticum" debe reconsiderase ya que diferentes análisis revelaron un biovar africano que puede tener su propio centro de diversidad genética.

Tabla 9. Principales huéspedes de $R$. solanacearum. (Fuente: Caruso, 2005)

\begin{tabular}{ccl} 
Raza & Biovar & \multicolumn{1}{c}{ Principales huéspedes } \\
\hline 1 & 1,3 y 4 & Tabaco, tomate, patata, otras solanáceas, cacahuete, malas hierbas \\
\hline 2 & 1,3 y 4 & Banano triploide y Heliconia spp. \\
\hline 3 & 2 & Patata, tomate, otras solanáceas, geranio y malas hierbas \\
\hline 4 & 3 y 4 & Jengibre (Zingiber officinales) y Curcuma alismalifolia \\
\hline 5 & 5 & Morera \\
\hline
\end{tabular}




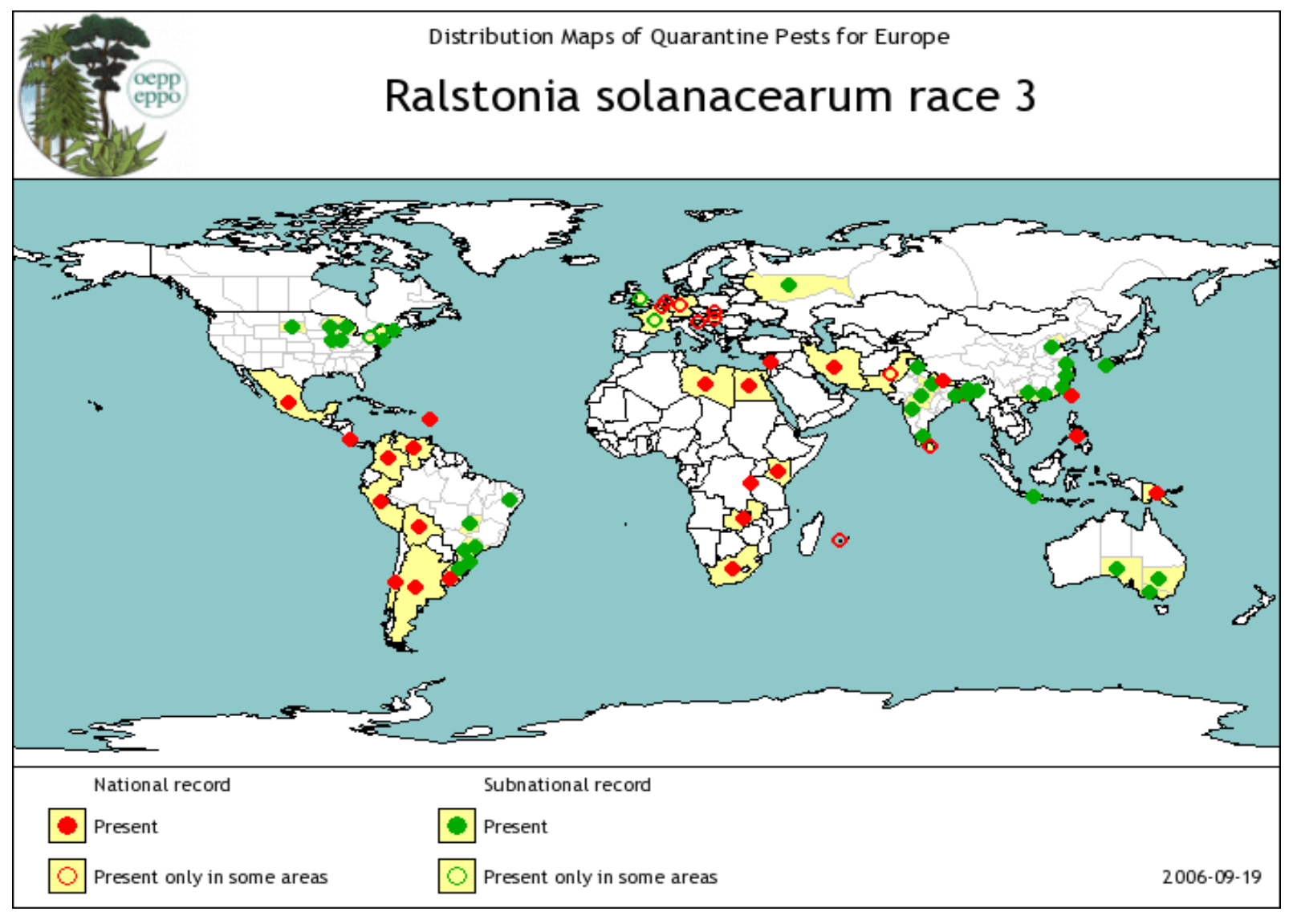

Figura 3. Distribución mundial de Ralstonia solanacearum (Fuente: OEPP/EPPO, 2006a)

Según el seguimiento de $R$. solanacearum en España, según recoge Caruso (2005) la enfermedad causada por la bacteria se detectó por primera vez en 1928. En 1992 aparece en las Islas Canarias y ya no se detectó hasta 1996, de nuevo en las islas y en Galicia. En las inspecciones realizadas entre los años 1999 y 2005 se confirmó su presencia en varias comunidades autónomas aislándose en Extremadura y Andalucía a partir de tomate. De acuerdo con Haward (1964 y 
1991) en los países del sur de Europa y de la zona mediterrránea el biovar 2 es el que se detecta.

\subsubsection{Caracterización bacteriana}

$R$. solanacearum es una bacteria Gram negativa, con forma de bastón. Su tamaño oscila entre $0,5-0,7 \times 1,5-2,5 \mu \mathrm{m}$ y no produce endosporas. Las células presentan fimbrias polares y contienen inclusiones de poli- $\beta$-hidroxibutirato usadas para su identificación (Caruso, 2005). Su crecimiento óptimo se produce a temperaturas entre 28 y $32{ }^{\circ} \mathrm{C}$, excepto para ciertas cepas de la raza 3 que son capaces de crecer a temperaturas inferiores (Thera, 2007).

Las características bioquímicas y fisiológicas más importantes de $R$. solanacearum se resumen en la tabla 10.

Tabla 10. Características bioquímicas y fisiológicas de $R$. solanacearum (Fuentes: Bergey's manual of systematic Bacteriology, con referencia Krieg y Holt, 1984; Schaad, 1988; Caruso, 2005)

\begin{tabular}{cc}
\hline Número de flagelos & $>1$ \\
\hline Pigmentos difusibles & $+/-$, marrones \\
\hline Arginina dihidrolasa & - \\
\hline Desnitrificación & + \\
\hline Crecimiento a $41^{\circ} \mathrm{C}$ & - \\
\hline Hidrólisis de gelatina & - \\
\hline Hidrólisis de almidón & + \\
\hline Oxidasa & + \\
\hline Catalasa & + \\
\hline Ureasa & - \\
\hline Utilización en el crecimiento de: & $+/-$ \\
\hline D-xylosa & - \\
\hline D-Ribosa & \\
\hline L-Rhamnosa & \\
\hline
\end{tabular}




\begin{tabular}{|c|c|}
\hline Sacarato & + \\
\hline Levulinato & $+/-$ \\
\hline Citraconato & - \\
\hline Mesaconato & - \\
\hline $\mathrm{D}(-)$ Tartrato & - \\
\hline meso-Tartrato & $+/-$ \\
\hline Erythritol & - \\
\hline Adonitol & - \\
\hline 2,3- Butileno glicol & - \\
\hline m-hidroxibenzoato & - \\
\hline Tryptamina & - \\
\hline$\alpha$-Amilamina & - \\
\hline Geraniol & - \\
\hline \multicolumn{2}{|c|}{ Producción de ácidos a partir de: } \\
\hline Glucosa & + \\
\hline Fructosa & + \\
\hline Galactosa & + \\
\hline Sacarosa & + \\
\hline Glicerol & + \\
\hline Inositol & + \\
\hline \multicolumn{2}{|l|}{ Crecimiento a pH: } \\
\hline 4,5 & - \\
\hline 5,5 & + \\
\hline 9,0 & - \\
\hline
\end{tabular}

El crecimiento de la bacteria en medio de cultivo "in vitro" es más lento que "in planta" y su identificación puede resultar difícil debido al aspecto variable de las colonias en placa (Caruso, 2005). Las colonias pueden ser: mucosas, opacas no mucosas, no mucosas y tipos intermedios. Tanto en los diferentes medios de cultivo como en planta, se producen cantidades masivas de EPS I (Polisacaridos Extracelulares), importantes para una rápida colonización sistémica por parte del 
patógeno así como para los síntomas de marchitamiento observados tras la infección (Kang et al., 1999) existiendo evidencias de que ciertos síntomas característicos de la enfermedad bacteriana están causados por dichos EPS (AraudRazou, 1998; Ofuya y Wood, 1981; Schell, 2000).

Las células bacterianas formadoras de colonias mucosas son no flageladas e inmóviles, mientras que las no mucosas (mutantes avirulentos que no sintetizan EPS I) están formadas por bacterias altamente móviles y flageladas. Los aislados virulentos en el medio general YDA (Yeast Dextrose Agar) son blanquecinos, lechosos y mucosos mientras que en medio sólido conteniendo sales de tetrazoilo las colonias virulentas son redondeadas, blanquecinas y con una zona rosada en el centro (Kelman, 1954). Por su parte, en medio con tetrazoilo las colonias avirulentas adquieren una coloración roja oscura. Esta diferencia en la morfología de las colonias se debe a la escasa afinidad de los EPS para las formas reducidas de las sales de tetrazoilo y por ello, las colonias mucosas desarrollan el color rojizo más lentamente en la zona central que las avirulentas no mucosas (Caruso, 2005).

Existe una conversión fenotípica mediante la cual, las colonias mucosas pasan a no mucosas, representando una estrategia adaptativa que permite a la bacteria asegurarse la supervivencia en nichos específicos y adaptarse a diferentes condiciones ambientales. Este cambio es ventajoso en ausencia de huéspedes, cuando la bacteria vive en el agua o en el suelo. La conversión fenotípica sólo ha sido observada "in vitro" aunque es muy posible que un comportamiento similar se de en suelos, agua u otros sustratos en los que puede vivir la bacteria. Thera (2007) recoge que en agua destilada y estéril el patógeno se puede mantener durante años, en condiciones ambientales, pero el largo tiempo de almacenamiento en medio líquido y la falta de oxígeno puede inducir la pérdida de virulencia caracterizada por cambios morfológicos en las colonias. De nuevo se confirma que las colonias virulentas son mucosas, con forma irregular, blanquecinas con el centro rosadorojizo tras mantenerlas en medio con tetrazoilo entre 36 y $48 \mathrm{~h}$. Por otra parte, las 
colonias no virulentas son redondeadas, más pequeñas y de color rojo oscuro (Kelman, 1954). Los aislados de la bacteria tienen una baja tolerancia a los medios salinos y su crecimiento se ve fuertemente inhibido por concentraciones de cloruro sódico entre 0,5 y 1,7\% (Caruso, 2005).

\subsubsection{Ciclo del patógeno}

Atendiendo al estudio de Caruso (2005) la bacteria es capaz de sobrevivir durante largo tiempo en el suelo, aún en ausencia de plantas hospedadoras. La penetración en las plantas ocurre, en la mayoría de los casos, a través de heridas, suponiendo que se mantiene en estado de latencia en el suelo y en el sistema radicular de plantas. Cuando las solanáceas crecen, los exudados de las raíces llegan hasta las bacterias y actúan como estímulos provocando una quimiotaxis del patógeno hasta las raíces. En un principio, las células bacterianas móviles y avirulentas colonizan la rizosfera de las plantas huéspedes, sin requerir de la superación de barreras endodérmicas suberizadas puesto que el patógeno ataca las zonas donde están dañadas. Tras 4 ó 5 días las bacterias llenan los vasos xilemáticos probablementa ayudadas por la acción de sus enzimas celulolíticos que actúan contra la pared de los vasos. Según Timms-Wilson et al. (2001) y Rahman et al. (1999), las células en el xilema se expanden por toda la planta estableciendo focos de infección. Los factores de virulencia que emplea el patógeno en la colonización del húesped son: enzimas líticos, extrapolisacaridos EPS, endoglucanasas y endopoligalacturonasas, convirtiéndose en los responsables de la degradación de tejidos. Así, una vez invadidos, las bacterias virulentas se multiplican en el interior de los vasos difundiéndose hacia la parte superior de la planta hasta obstruirla. Transcurridos 7 días la bacteria ya se detecta en los tallos de tomate y al llegar el octavo día ya se pueden realizar aislamientos bacterianos de hasta $10^{10}$ células por $\mathrm{cm}$ de tallo (Saile et al., 1997; Schell, 2000). De acuerdo con Saile et al. (1997) la producción de EPS contribuye al marchitamiento de las plantas afectadas. Una vez las plantas se han marchitado y muerto, las bacterias 
virulentas llegan al suelo sobreviviendo en los restos de plantas muertas. En este momento también pueden sufrir la conversion fenotípica, recuperar movilidad y volverse avirulentas. Tans-Kersten et al. (2001) encontraron que, efectivamente, $R$. solanacearum resulta no mótil en los vasos xilemáticos sugiriendo la existencia de una "estructura reguladora" que respondiese a una señal por parte de la planta para activar la invasión. Estos autores confirmaron la motilidad bacteriana (en medios de cultivo) con la presencia de cuatro flagelos polares, confiriendo esta característca el inicio de la colonización e invasión de cultivos. Se demostró la necesidad de motilidad para invadir de forma efectiva y luego colonizar las plantas huéspedes.

Esta bacteria presenta un estado "viable pero no cultivable" (VBNC) haciendo referencia a la incapacidad de ciertas células a crecer en un medio de cultivo. Este fenómeno es común a un amplio espectro de bacterias Gramnegativas, saprofitas, patógenas de vegetales y simbióticas. Este estado se considera una estrategia que permite a estas bacterias sobrevivir en situaciones ambientales críticas (Colwell et al., 1985; Roszak y Colwell, 1987). En cuanto a las condiciones, $R$. solanacearum se convierte en VBNC después de permanecer tres días en un suelo estéril o en agua durante las estaciones frías (Grey y Steck, 2001; Van Elsas et al., 2001). El factor más importante en la inducción de este estado parece ser la baja temperatura (Van Elsas et al., 2000). El restablecimiento de la condición normal de las células a partir del estado VBNC o resucitación, no es un mecanismo simple de instaurar. López et al. (2003) indicaron que si estas células no cultivables pueden o no ser capaces de infectar nuevos huéspedes susceptibles y desarrollar los síntomas de la enfermedad, es una cuestión sin dilucidar.

\subsubsection{Síntomatología relacionada y patogenicidad}

Los síntomas en campo dependerán tanto de la severidad de la infección como de las condiciones ambientales. La enfermedad de marchitamiento bacteriano en tomate se caracteriza por la siguiente sintomatología: las hojas jóvenes son las 
primeras en verse afectadas tomando una apariencia flácida, normalmente en los momentos más cálidos del día. El marchitamiento de la planta entera puede acontecer rápidamente si las condiciones ambientales son favorables para el patógeno. Si por el contrario las condiciones ambientales son menos favorables la enfermedad se desarrolla más lentamente, también se puede observar un decaimiento y se producen un gran número de raíces adventicias en el tallo. Los vasos conductores en el tallo muestran coloraciones pardas y si se realiza un corte transversal, se puede observar un exudado mucoso, blanquecino-amarillento fácilmente identificable en contacto con el agua (OEPP/EPPO, 2004a).

En relación con la sintomatología y detección de aislados patógenos, hay que hacer referencia a la respuesta hipersensible (HR) observada en hojas de tabaco tras infiltrar soluciones bacterianas. La HR es un mecanismo de defensa inducido en la planta por la presencia del patógeno tras ser inoculado en un huésped no compatible. Lozano y Sequeira (1970) demostraron que la capacidad de provocar la HR en tabaco es un método útil y simple para determinar la raza de los aislados virulentos de este patógeno. El colapso de las células tras $12 \mathrm{~h}$ sugiere que es el tiempo necesario para sintetizar la concentración necesaria de sustancias para causar la muerte del huésped y de las células vegetales. Se demostró que las cepas de la raza 1, patógena en tabaco, provocan una formación necrótica rodeada de un halo amarillo, las cepas de la raza 2 (no patógena en tabaco) inducen una rápida HR en las áreas infiltradas y la raza 3 (no patógena en tabaco) produce una decoloración amarilla. Estas reacciones dependen de varios factores como la concentración de inóculo, periodo de exposición a la luz y temperatura de incubación. Concentraciones inferiores a $3,5 \times 10^{7}$ células $\mathrm{ml}^{-1}$ no inducen o retrasan la HR. Respecto a la temperatura la exposición de plantas infiltradas a 16 ${ }^{\circ} \mathrm{C}$ retrasa la aparición de la HR hasta 72 h. 


\subsubsection{Fuentes de inóculo, control y prevención.}

Como ya se ha comentado, $R$. solanacearum tiene una gran capacidad de diseminación a través de distintos medios como el agua, el suelo, herramientas de trabajo, insectos, nematodos y malas hierbas que actúan como resevorio (Jackson y González, 1981). Además, las bacterias suelen invernar en las plantas enfermas o en los restos de plantas, órganos de propagación vegetativa y sobre semillas de algunas plantas huéspedes silvestres (Agrios, 2002).

Las bacterias infectarán a la planta a través de heridas, mayoritariamente en las raíces, por lo que la presencia de determinadas especies de nematodos incrementarán la infección (Thera, 2007). De acuerdo con Deberdt et al. (1999) las poblaciones de $R$. solanacearum y de nematodos suelen coexistir en áreas tropicales y subtropicales; la presencia de nematodos en raíces incrementa la incidencia de la enfermedad bacteriana.

La temperatura representa uno de los factores que más afecta la interacción entre huésped y patógeno, así como la supervivencia de la bacteria en el suelo. En general, una temperatura entre 30 y $35^{\circ} \mathrm{C}$ acrecienta el porcentaje de ataque de $R$. solanacearum aunque no todas las cepas se comporten exactemente igual (Caruso, 2005; Hayward, 1991). En condiciones de campo y bajo situaciones favorables de humedad, se desencadena el marchitamiento de las plantas dependiendo su severidad de la temperatura del suelo, humedad, tipo de suelo, susceptibilidad de la planta huésped y de la virulencia de las razas. Momol et al. (2003) concluyen en su trabajo que temperaturas relativamente elevadas y altas humedades en el suelo son los factores más importantes asociados a la incidencia y severidad de la enfermedad causada por $R$. solanacearum.

$R$. solanacearum puede sobrevivir en el suelo durante varios años y la alta variabilidad en la incidencia de la enfermedad en el campo confirmaría que muchos son los factores que afectan a su supervivencia en el mismo (Granada y Sequeira, 1981). 
En 1976, McCarter recogía en sus investigaciones que la bactería podía persistir hasta 4 años en distintos suelos infectados de forma artificial, señalando la distribución errática y la persistencia impredecible del patógeno en caso de infecciones naturales en condiciones de campo. Este comportamiento también quedó indicado por Nesmith y Jenkins (1983), señalando la importante función del amplio rango de plantas huéspedes (incluyendo malas hierbas) y confirmando que, aunque la enfermedad no se distribuye de forma uniforme en un mismo terreno afectado (ni de campo en campo), las dispersiones secundarias que afectan a zonas más delimitadas recuperan uniformidad, concluyendo que la supervivencia bacteriana quedaría limitada a pequeñas zonas y se vería influenciada por factores permanentes como el tipo de suelo, la topografía del terreno y la cubierta vegetal así como que en caso de suelos desnudos (mantenidos en barbecho) la bacteria es capaz de sobrevivir.

Davi et al. (1981) estudiaron la supervivencia de $R$. solanacearum en el suelo y, bajo condiciones de laboratorio, comprobaron ciertos efectos ejercidos sobre la población bacteriana como consecuencia de la adición de enmiendas. Además, el patógeno sobrevivió en la rizosfera de las plantas no huéspedes pertenecientes a las familias Acanthaceae y Leguminosae, incluso en ausencia de plantas huéspedes, pero su incidencia en la rizosfera de gramineas y ciperaceas fue menor.

Hayward (1991) también indicaba la temperatura como el factor más importante que afecta la interacción planta-patógeno así como su supervivencia en el suelo. Una temperatura ambiental de $30-35{ }^{\circ} \mathrm{C}$ incrementa la incidencia de la enfermedad causada por algunas de las razas bacterianas en huéspedes como el tomate y temperaturas cercanas a $\operatorname{los} 32{ }^{\circ} \mathrm{C}$ (alcanzadas de forma articial en cámaras controladas) incrementaron significativamente la severidad de los síntomas incluso en dos variedades de tomate resistentes al machitamiento bacteriano causado por $R$. solanacearum. Por otro lado, este mismo autor recoge que suelos sometidos continuamente a $43{ }^{\circ} \mathrm{C}$ durante periodos de 4 días o más, 
aparecieron libres del patógeno. En cuanto a temperaturas bajas, se comprobó la supervivencia bacteriana a $4{ }^{\circ} \mathrm{C}$ en muestras de suelos infectados de forma natural que permanecieron encerradas en bolsas de plástico durante 673 días. Altas humedades en suelos bien drenados también favorecen la dispersión del patógeno. También Melton y Powell (1991) indican la ausencia de enfermedad bacteriana en zonas donde las temperaturas son inferiores a $10^{\circ} \mathrm{C}$.

En cuanto a profundidad, en dos terrenos infectados de forma natural con la raza 3 de la bacteria, esta fue detectada a profundidades entre 15 y $75 \mathrm{~cm}$, para ello Graham y Lloyd (1979) emplearon plantas indicadoras. Por otro lado, en suelos que fueron arificialmente infectados, la bacteria se recuperó en mayores cantidades en muestras de entre 55 y $65 \mathrm{~cm}$ de profundidad, usando, en este caso, placas con medio de cultivo selectivo. Estos resultados sugieren que, en ciertos tipos de suelo, el patógeno puede sobrevivir durante largos periodos de tiempo en las capas profundas. En determinados terrenos de regiones frías los suelos permanecieron altamente infectados por $R$. solanacearum durante un periodo de dos años $\mathrm{y}$, otros estudios demostraron que para la raza bacteriana que afecta a tabaco y en caso de suelos en barbecho, se confirmaría su presencia durante más de 4 años.

Para el control de la bacteria, las medidas que se toman son tanto preventivas como curativas. Las primeras incluyen desde el uso de material vegetal sano al empleo de variedades resistentes. Dentro de las curativas se incluyen el control químico, biológico e integrado.

Ninguno de los pesticidas convencionales han proporcionado un control efectivo de la bacteria y Ji et al. (2005) recogen que los fumigantes tradicionales empleados en la desinfección de suelos como el BM no aportan un control satisfactorio a la enfermedad bacteriana. Estos mismos autores insisten en la dificultad de su control incidiendo en la problemática rotación de cultivos al emplear plantas no huéspedes ya que las malas hierbas pueden actuar como reservorios y debido al amplísimo rango de plantas que pueden invadir. Sobre el 
uso de cultivares resistentes, sobre todo de tomate, no son fácilmente aceptados por los agricultores ni por la industria tomatera debido a su baja calidad hortícola y a los niveles variables de resistencia como consecuencia de la variación del patógeno en diferentes condiciones. También afirman que algunos compuestos volátiles liberados de algunas plantas tienen efecto positivo en el control de la enfermedad, basando su estudio en el uso de thymol, aceite esencial obtenido de plantas aromáticas y medicinales como Thymus vulgaris, Carum ajowan (Ptychotis ajowan), Mentha longlifolia y Monarda spp.

Algunos productos como la cloropicrina, 1,3-D y metam-sodio, han mostrado cierta eficacia reduciendo la incidencia y severidad de la infección (Caruso, 2005). El uso de cloropicrina, cubriendo el suelo tras su aplicación o sellado con agua, fue el mejor se los tratamientos que proporcinó un cierto control de Ralstonia solanacearum (Enfinger et al., 1979). Según Melton y Powell (1991) se recomiendan rotaciones de cultivos con duraciones entre 3 y 5 años, el empleo de cultivares resistentes y la combinación de rotaciones, resistencias y fumigaciones con 1,3-D con cloropicrina o con cloropicrina sola.

Actualmente se han comprobado que no existe un control químico totalmente efectivo representando las prácticas culturales un importante componente en el control integrado. La rotación con plantas no huéspedes de la bacteria representa un medio efectivo de descenso del patógeno en el suelo. La rotación con cereales y/o gramíneas reduce el potencial de inóculo presente en el suelo. La siembra de liliaceas y brassicas favorece la eliminación de malas hierbas que pueden servir de reservorio. Leguminosas y cucurbitáceas pueden emplearse en programas de rotación por no ser huéspedes evitando el cultivo de solanáceas como patatas, tomates, berenjenas, pimiento o tabaco. Las prácticas de irrigación y abono en bajas dosis son tamién importantes (Caruso, 2005).

Para Thera (2007) la manera más eficiente para el control de enfermedades es prevenir su introducción en las zonas de producción de cultivos mediante métodos de cuarentena y métodos fitosanitarios. Para un manejo 
adecuado de la enfermedad, después de la introducción de métodos de manejo integrado que incluyen controles culturales como rotaciones con cultivos no huéspedes, incorporación de enmiendas en el suelo, periodos de barbecho o inundaciones anaeróbicas, es necesario el uso tanto de material vegetal libre de patógenos como de cultivares resistentes.

Respecto al empleo de enmiendas en el suelo, Islam y Toyota (2004) concluyeron que la marchitez bacteriana del tomate fue suprimida en suelos enmendados con gallinaza y FMY, del inglés "FarmYard Manure" (estiércoles de corral) detectándose una elevada actividad microbiana, posible responsable del efecto.

Alcalá y Lara (1995) tras un análisis de suelo encontraron correlación entre el nivel de compost en el suelo y la presencia de la bacteria que permanecía durante más tiempo en suelos con menor contenido en materia orgánica.

Gorissen et al. (2004) demostraron que la adición al suelo de estiércoles líquidos de cerdo disminuyeron de forma significativa las poblaciones de $R$. solanacearum y también se redujo el número de plantas infectadas y con síntomas de la enfermedad. Por otra parte, encontraron que la solarización del suelo también redujo la supervivencia de la bacteria pero no incrementó la supresividad del suelo evaluada por el desarrollo de síntomas en plantas, transcurridas 9 semanas tras el tratamiento. Combinando estiércoles de cerdo y solarización se obtuvieron los mejores resultados, aunque plantas aparentemente sanas en suelos tratados de esta forma, en ocasiones, mostraron la presencia bacteriana en estado latente, sobre todo en las partes bajas del tallo.

Michel y Mew (1998) determinaron la importancia de los iones inorgánicos de $\mathrm{N}$ producidos durante la descomposición de la urea incluyendo nitratos, nitritos y amonio en la supresión de $R$. solanacearum. La enmienda empleada estaba compuesta por urea y $\mathrm{CaO}$, obteniéndose una disminución en la población del patógeno debido al elevado $\mathrm{pH}$ del suelo especialmente durante la hidrólisis de la urea. 
Los resultados obtenidos por Pradhanang et al. (2003) mostraron el efecto de distintos aceites esenciales obtenidos de plantas en la densidad de poblaciones de $R$. solanacearum y en la incidencia de la marchitez bacteriana del tomate concluyendo que algunos de estos aceites, especialmente el de Thymol, las redujeron mientras que se favoreció el crecimiento de las plantas.

Los efectos de la adición de compost y de una solarización simulada en el control del biovar 2 de la bacteria patógena en el suelo fue estudiado por Schönfeld et al. (2003) que demostraron que la solarización sola no se mostraba eficaz pero sí en combinación con el compost empleado (desperdicios domésticos) disminuyendo el número de plantas enfermas tras los tratamientos.

Mathiessen y Kirkegaard (2006) recogen el efecto de la biofumigación, empleando brassicas como material adicionado al terreno, en el control de la bacteria. Se trata de una revisión de los resultados comenzando con los obtenidos con B. juncea (mostaza india) que aplicada como abono verde resultó efectiva en la reducción del nivel de marchitamiento bacteriano reduciendo la incidencia de la enfermedad en un cultivo posterior de tabaco (Akiew y Trevorrow, 1999). También se ensayaron un gran número de especies de brassicas incluyendo, además de $B$. juncea, B. napus, Sinapis alba (mostaza blanca), Raphanus sativus y B. nigra (mostaza negra) todos ellos con actividad biofumigante basada en la toxicidad de sus isotiocianatos. La sensibilidad general de $R$. solanacearum a los isotiocianatos se confirmó mediante ensayos de laboratorio realizados por Smith y Kirkegaard (2002) mostrándose el 2-phenylethyl isotiocianato como compuesto más eficaz en condiciones "in vitro". Akiew et al. (2005) continuaron el estudio del impacto de los isotiocianatos contra la bacteria demostrando que aquellas brassicas con una mayor cantidad de glucosinolatos, precursores de los isotiocianatos, como las mostazas, resultaron más efectivos que aquellos biofumigantes con menores concentracones o que desprendían menos compuestos volátiles en su descomposición. La información aportada por los experimentos llevados a cabo en laboratorio apoyaría la obtenida por Matthiessen y Sackleton (2005) sugiriendo que 
las mostazas altas en propenil isotiocianato serían los mejores biofumigantes contra $R$. solanacearum bajo condiciones adecuadas en el campo que favorecieran la distribución de las sustancias volátiles. En este caso se compararon los efectos de adición al suelo tanto de brassicas como de otros tipos de residuos vegetales, seleccionando una leguminosa como la soja. Como conclusión, todos los biofumigantes empleados retrasaron el comienzo y redujeron la incidencia y severidad de la marchitez bacteriana causada por $R$. solanacearum en las plantas de tomate crecidas sobre el terreno tras los tratamientos, recordando que los mejores resultados se siguieron obteniendo con el empleo de mostazas.

Baptista et al. (2007) estudiaron la eficiencia de la solarización y biofumigación en el control de la enfermedad causada por $R$. solanacearum en cultivos de tomate, aunque estudian sus efectos por separado, sin combinaciones. Para ello emplearon gallinaza como enmienda (en proporciones de ensayo de 2 y 5\%) y láminas de PE transparente de $75 \mu \mathrm{m}$ de espesor. Como resultado más significativo obtuvieron que sólo la solarización durante un periodo de 4 meses y la biofumigación con 5\% de gallinaza redujeron significativamente la incidencia de la enfermedad. Además, la solarización supuso una reducción en el contenido de $\mathrm{Na}$ y $\mathrm{K}$ tras 4 y 6 meses de su aplicación sin otros efectos significativos en las propiedades químicas del suelo. La biofumigación incrementó los niveles de nutrientes en el suelo y la biomasa microbiana efecto, este último, obtenido también por la solarización transcurridos 60 días desde su aplicación.

\subsubsection{Metodología de diagnóstico}

$R$. solanacearum es patógeno de cuarentena en la Unión Europea. Su detección y control se describen en la Directiva 98/57/EC con el propósito de limitar la dispersión del patógeno. La EPPO recoge el procedimiento oficial para detectar la bacteria tanto en muestras sintomáticas como asintomáticas (OEPP/EPPO, 2004a). 
French et al. (1995) indican que uno de los principales problemas en el desarrollo de estrategias eficientes para controlar la enfermedad causada por $R$. solanacearum es la falta de métodos simples y rápidos para detectar al patógeno en muestras de plantas, suelo y agua. Los métodos tradicionales se basan en cultivos e identificación morfológica y bioquímica de las colonias así como en los comentados test de patogenicidad o el empleo de plantas indicadoras (Graham y Lloyd, 1978).

El aislamiento directo con aislamientos en medios de cultivo es el método más antiguo y utilizado para el diagnóstico y detección de bacterias fitopatógenas (Chen y Echandi, 1982; Karganilla y Buddenhagen, 1972; Nesmith y Jenkins, 1979). Para que se desarrollen las colonias se aconseja dejar las placas sembradas en incubación durante al menos 3 días a $28^{\circ} \mathrm{C}$, aunque puede prolongarse hasta seis días. Aunque las siembras en medio selectivo puede utilizarse como única prueba de selección, se pueden obtener resultados negativos por inhibición del crecimiento del patógeno debido a la presencia de otras bacterias en el medio. Una vez aisladas y purificadas se emplean varios métodos para su diagnóstico. Entre los métodos de diagnosis destacan los serológicos y, dentro de las técnicas moleculares, la reacción en cadena de la polimerasa (PCR). Diversos autores han diseñado cebadores específicos para la detección de la bacteria a nivel intraespecífico como los empleados por Boudazin et al. (1999). Van der Wolf et al. (2000) emplearon la inmunofluorescencia para la detección y cuantificación de $R$. solanacearum verificando los resultados positivos mediante PCR y dilución en placas de cultivo.

Según Dittapongpitch y Surat (2003) son numerosos los métodos desarrollados para la detección de $R$. solanacearum. Estos autores también indican como los más comunes el cultivo en placas en medio selectivo y la técnica serológica ELISA. Por su parte, Galal et al. (2003) sugieren que al menos se necesitan tres métodos cada vez y cita como ejemplos cultivos en medios semiselectivos, test de inmunofluorescencia y el empleo de plantas bioindicadoras como el tomate para la raza 3. 
Una de las razones para desarrollar métodos seguros de detección se relaciona con la catalogación de la bacteria como patógeno de cuarentena ya que hay que evitar su propagación en el campo o en condiciones de almacenamiento de material vegetal, especialmente en ausencia de síntomas ya que no siempre significa la ausencia de patógenos que pueden permanecer latentes (French et al., 1995).

López et al. (2003) indicaron como uno de los métodos más fiables el uso de plantas trampa mediante la siembra en campo de un cultivo sensible como patatas o tomates y el seguimiento de la aparición de síntomas en las plantas. También señalaron otras ténicas de gran interés como la técnica DASI-ELISA con anticuerpos monoclonales específicos, incluso un método de PCR cooperativa. Estos autores son capaces de detectar la bacteria tanto en ecosistemas acuáticos como en el suelo, permitiendo detectar las células viables como las VBNC. Concluyen su estudio indicando que una vez introducida la enfermadad en el suelo conlleva dificultades precisando del uso de medidas preventivas, metodologías sensibles y específicas que permitan su detección, así como programas de control integrado. También señalan la importancia de conocer como sobreviven las bacterias fuera de los huéspedes susceptibles.

\subsection{Clavibacter michiganensis subsp. michiganensis}

Clavibacter michiganensis subsp. michiganensis (Smith 1910) Davis et al. 1984, se describió en 1910 como causante del chancro bacteriano del tomate, del inglés "Bacterial canker of tomato". Actualmente se trata de un patógeno ampliamente distribuido en todo el mundo incluyendo la zona EPPO donde se considera un patógeno de cuarentena, también perteneciente a su lista A2. En la figura 4 se recoge su distribución a nivel mundial pudiendo observar que en España se distribuye por todo el terrirorio nacional (OEPP/EPPO 2005, 2006b).

Su principal planta huésped es el tomate Lycopersicon esculentum, pero también se ha detectado en pimientos (Moffet y Wood, 1984), berenjenas y en 
malas hierbas solanáceas como Solanum douglasii, S. nigrum y S. triflorum. Además, un amplio rango de otras solanáceas son susceptibles al realizarse inoculaciones artificiales (Thyr et al., 1975) así como también se señalan como huéspedes artificiales y tras realizar inoculaciones en el tallo: trigo, cebada, centeno, avena, girasoles, sandías y pepinos. Chang et al. (1992) identificaron como reservorios para su distribución epífita y para su distribución Datura stramonium, Chenopodium album y Amaranthus retroflexus. Aún así, en todo la zona EPPO el tomate aparece como principal huésped mientras que algunas de las malas hierbas pertenecientes a las solanáceas, anteriormente señaladas, son sus reservorios más importantes (OEPP/EPPO, 2005). Otros estudios se centran en la superviverncia de la bacteria en el suelo e incluso en algunas investigaciones se encuentran referencias que indican que C.m.michiganensis pude permancer hasta 8 años en el suelo (Trevors y Finnen, 1990).

\subsubsection{Caracterización bacteriana}

C.m. michiganensis presenta colonias lisas, brillantes con márgenes enteros y coloración amarilla en medios nutritivos generales. Se trata de una bacteria aerobia, gram positiva y que no esporula. Con metabolismo oxidativo de la glucosa, catalasa positiva, oxidasa negativa, producción de ácido de la manosa en condiciones aeróbicas positiva, crece en presencia de $6 \%$ de $\mathrm{NaCl}$, hidrólisis de almidón positiva y producción de $\mathrm{H}_{2} \mathrm{~S}$ a partir de peptona (OEPP/EPPO, 2005). 


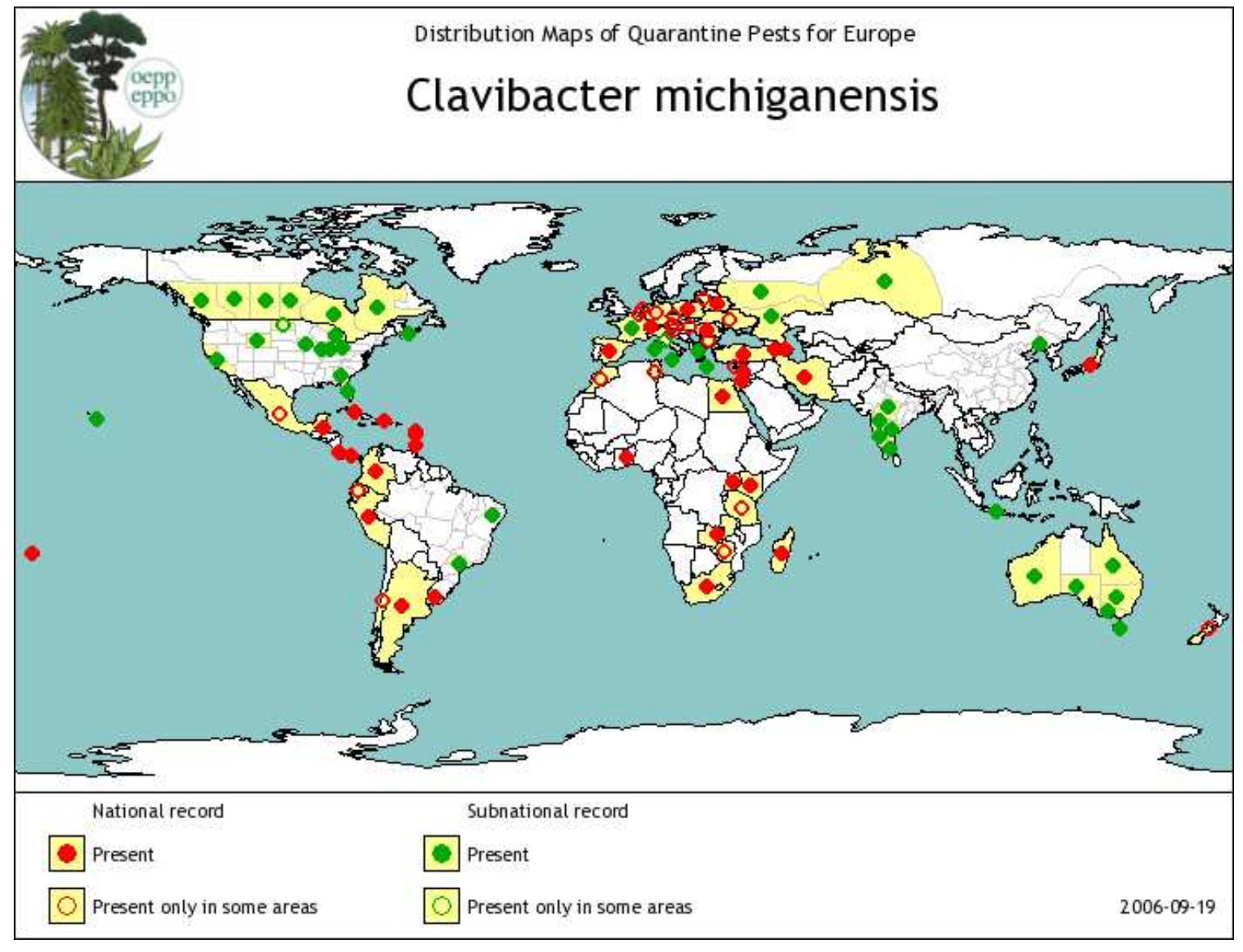

Figura 4. Distribución mundial de Clavibacter michiganensis subs. michiganensis (Fuente: OEPP/EPPO, 2006b)

\subsubsection{Ciclo del patógeno}

Las fuentes de inóculo del chancro bacteriano en tomate incluyen: su presencia en el suelo donde C.m.michiganensis permanece asociada a restos de cosecha, las malas hierbas que emplea como reservorios, el manejo de estacas afectadas y la transmisión por semilla. Además, la diseminación secundaria puede tener lugar por medio de las salpicaduras de agua, empleo de maquinaria contaminada o incluso a través de las manos de los trabajadores; del mismo modo se puede inocular a través del empleo de estacas enfermas o en el momento del corte para obtener trasplantes. En el caso de las estacas, los primeros síntomas 
aparecen en el tallo, exactamente en los lugares del mismo donde han sufrido algún tipo de abrasión. En el caso de los trasplantes, el periodo de latencia puede ser de 3 a 6 semanas, creando problemas en los programas de certificación basados en la apariencia visual. Aquellas plantas infectadas procedentes de semillas enfermas sufren síntomas muy diferentes: como caso extermo pueden morir, o pueden presentar problemas en el momento de la fructificación o, incluso, no desarrollar ningún tipo de síntoma. La infección secundaria se asocia, frecuentemente, con síntomas foliares, síntomas de "ojo de pájaro" en frutos, o ambos síntomas a la vez. Sin embargo, cuando esta infección secundaria resulta de la preparación de trasplantes dará lugar a infecciones sistémicas que supondrán la muerte de la planta (Jones et al., 1991).

La infección de la planta huésped se produce, de forma natural, a través de heridas, seguida de la invasión de los vasos xilemáticos tratándose, por tanto, de una enfermedad sistémica vascular (Wallis, 1977). Como la bacteria se localiza en un principio en el xilema, el transporte de agua se verá perjudicado contribuyendo al marchitamiento de las plantas afectadas (Jahr et al., 1999). Estos mismos autores recogen que, al igual que otras bacterias que afectan a plantas, C. michiganensis produce exopolisacaridos (EPS) que determinan numerosas e importantes funciones biológicas. Por ejemplo, estos EPS protegen a las bacterias de la deshidratación y las previenen de su detección por el sistema defensivo de las plantas huéspedes y, además de inducir el marchitamiento en el epicotilo de tomate, provocan la desintegración de la membrana tilacoidal de cloroplastos. Los EPS de C.m. michiganensis fueron caracterizados por Van der Bulk et al. (1991).

\subsubsection{Sintomatología relacionada y patogenicidad}

Según la OEPP/EPPO (2005) y de forma general, C.m.michiganensis causa infecciones sistémicas en plantas de tomate siendo el síntoma principal un marchitamiento sistémico (Jones et al., 1991). Esta bacteria también puede causar la aparación de manchas en hojas y frutos como resultado de una infección local, 
normalmente en condiciones de riegos aéreos. Existe un amplio rango de síntomas dependiendo del emplazamiento de las plantas (invernadero o campo), de su edad en el momento de la infección, de las prácticas culturales, etc. Además, existen razas que producen síntomas menos severos que otras. Gitaitis et al. (1991) indicaron la presencia de la bacteria en plantas asíntomáticas estudiando los métodos de detección para estos casos.

En invernaderos, la enfermedad bacteriana puede detectarse en los primeros estadíos mediante coloraciones en verde pálido, zonas aceitosas entre los nervios foliares que progresan hacia zonas secas que adquieren entonces coloraciones claras y que avanzan hasta necrosarse. Finalmente, toda la planta se ve afectada tomando una apariencia de "desecación", similar a la causada por fuertes intensidades solares que llegan a quemarlas o a un tratamiento excesivo con algún producto químico. Los síntomas de marchitamiento que se observan pueden confundirse con los causados por $R$. solanacearum, Fusarium spp. y Verticillium spp (OEPP/EPPO, 2005).

Conforme la infección sistémica va progresando, algunas de las hojas pueden marchitarse $\mathrm{y}$, con frecuencia, sólo afecta a los foliolos de una de las mitades. Este síntoma se observa durante los periodos de máxima transpiración. En caso de condiciones favorables para el desarrollo de la bacteria $\left(25-30{ }^{\circ} \mathrm{C}\right.$ y con estrés hídrico) los síntomas de marchitamiento y posterior seca afectan a las hojas completas en sólo unos días. Finalmente toda la planta se deseca.

Los frutos de plantas infectadas, también en condiciones de invernadero, pueden sufrir problemas en su desarrollo, caer prematuramente y madurar de forma irregular. Las típicas manchas bacterianas (tanto en hojas como en frutos) no aparecen en invernaderos si no se emplean riegos aéreos, especialmente por aspersión.

En el campo, según Carlton et al. (1998) los foliolos de la hojas más viejas se rizan, los márgenes amarillean y al final se necrosan debido a la entrada del patógeno a través de los hidatodos. Las plantas crecen poco y, conforme los 
síntomas avanzan, van desecándose de forma gradual. En los tallos se pueden observar heridas longitudinales que pueden rajarse y abrirse formando chancros. $\mathrm{La}$ médula puede colapsarse completamente y en el caso de los frutos, los síntomas comienzan como pequeñas lesiones con un halo blanquecino alrededor. Estas lesiones van progresando hasta desarrollar manchas con coloraciones marrones en el centro y comunmente se dice que adquieren un aspecto de "ojo de pájaro", del inglés "bird's eye"; estas lesiones en frutos tienen un tamaño entre 3-6 mm de diámetro. En su interior, el fruto puede contener zonas amarillentas que alcanzan a las semillas. Algunas lesiones se observan cerca del cáliz donde también pueden distinguirse coloraciones amarillentas (Jones et al., 1991; OEPP/EPPO, 2005).

Independientemente de donde ocurra la infección y respecto a los síntomas generales, los peciolos de las hojas permanecerán turgentes hasta que los foliolos se vean afectados. De forma general, las hojas situadas en las partes más bajas son las primeras en marchitarse, permaneciendo las más altas turgentes hasta la fase final de la enfermedad. Sin embargo, si la infección comienza como consecuencia de una herida durante la poda de la yema terminal, la enfermedad se desarrolla primero en la parte alta y rápidamente se dispersa por toda la planta hasta matarla. Del mismo modo, en el tallo pueden aparecer raíces adventicias y no siempre se observan chancros (Jones et al., 1991).

En ciertas plantas no huéspedes o resistentes, las bacterias patógenas pueden producir respuesta hipersensible (HR) considerada, como se ha recogido en el apartado 2.1.3, como una rápida respuesta en el lugar de la invasión patogénica y caracterizada por la muerte celular. Gitaitis (1990) indicó que determinadas razas virulentas de C.m. michiganensis inducían una reacción hipersensible, en forma de respuesta necrótica, en plantas de Mirabilis jalapa. En otros estudios (Gitaitis y Beaver, 1990) se recogía la laboriosidad de la identificación mediante test de patogenicidad así como la dificultad de identificar la bacteria en plantas, o partes de éstas, que no presentan síntomas. Por ello, estos autores emplean el análisis de lípidos, concretamente de ésteres metílicos de ácidos grasos (del inglés "fatty acid 
methyl esters, FAMEs") analizados mediante cromatografía de gases que, además de para identificar diferentes razas de C.m.michiganensis, también ayudan a distinguir la bacteria de otras gram-positivas que presentan morfologías similares.

\subsubsection{Fuentes de inóculo, control y prevención}

Las principales fuentes de inóculo han sido citadas en el apartado 2.2.2. reconociéndose como las principales causas el empleo de semillas y trasplantes infectados. Pero se ha demostrado que el patógeno puede sobrevivir durante muchos meses en asociación con restos vegetales, donde puede invernar y esperar a que las condiciones ambientales resulten favorables afectando, de este modo, a las plantas del cultivo siguiente (Moffet y Wood, 1984). Aún así, se ha comprobado que las poblaciones bacterianas detectadas son menores en los restos enterrados que en los abandonados sobre la superficie del terreno donde la descomposición es más lenta y la interacción con otros microorganismos es menor (Chang et al., 1992; Gleason et al., 1991). También ha quedado demostrada la capacidad infectiva de la bacteria por vía radicular (Gómez et al., 2006).

En 1967, Strider publicó estudios de supervivencia confirmando que la bacteria era capaz de invernar tanto en suelos franco-arenosos como en agua (destilada previamente o corriente). Sin embargo, no se detectó en suelos que fueron secados al aire transcurridos 8 meses tras su inoculación, ni tampoco en asociación con los alambres empleados para el emparrado de cultivos tras 3 meses de su contaminación. Para estos mismos autores, C.m.michiganensis permaneció durante 18 meses viable y virulento en suelos que se conservaron húmedos en frascos que se almacenaron a temperatura ambiente y hasta 30 meses en agar nutriente a $2{ }^{\circ} \mathrm{C}$.

Por su parte, Echandi (1971) indicó que el patógeno podía sobrevivir sólo durante 2 semanas cuando se introducía en el suelo como células libres, es decir, directamente. Del mismo modo, encontró que era capaz de invernar en material vegetal en descomposición, corroborando los resultados de Strider (1967). 
Aunque la longevidad del patógeno en el suelo varía dependiendo de la región o localidad en estudio y de distintos factores que incluyen la temperatura, humedad, pH, y antagonismo microbiano, entre otros (Basu, 1970), son numerosos los estudios realizados que facilitan avances sobre las condiciones de supervivencia de C.m.michiganensis (Gleason et al. 1988; Gleason y Braun, 1990; Gleason et al. 1991). Según estos últimos autores la bacteria sobrevivió por lo menos 24 meses en asociación con restos de cosecha en la superficie del suelo pero esta cifra se redujo a 7 meses si estos restos se enterraban. Tras tres años de experimentación en campo verificaron que tanto frutos como foliolos de plantas de tomate pueden soportar elevadas poblaciones epífitas de C.m.michiganensis, transcurriendo entre 5 y 7 semanas entre su establecimiento y el desarrollo de necrosis en hojas y entre 4 y 6 semanas hasta observarse la enfermedad en plantas adyacentes e infectadas de forma sistémica.

La temperatura aparece como uno de los principales factores que afectan a la supervivencia de la bacteria. Basu (1970) estudió como progresan las poblaciones del patógeno asociadas a restos de cosecha en condiciones de suelos sometidos a bajas temperaturas (que incluso llegan a helarlo) y en el caso de suelos sometidos a altas temperaturas (que lo calientan). Así, la bacteria sobrevivió hasta 36 semanas en hojas de tomate mantenidas a $-20{ }^{\circ} \mathrm{C}$ pero no se detectó después de tres semanas de tratamientos en un rango de temperaturas comprendido entre 5 a $35^{\circ} \mathrm{C}$. De los resultados del estudio térmico se desprende que, bajo condiciones de invernadero, C.m.michiganensis no es capaz de sobrevivir más de 3 ó 4 semanas. Para evitar la posibilidad de infecciones primarias a partir de suelo contaminado, el suelo puede someterse a altas temperaturas durante 4 semanas antes de sembrar o trasplantar. También la humedad influye en la supervivencia del patógeno, aunque menos que la temperatura y, de hecho, la humedad del suelo, per se, no limita la capacidad de supervivencia del patógeno (Basu, 1970; Moffet y Wood, 1984). El tipo de suelo también se ha indicado como factor influyente en el patógeno cuando éste se asocia a restos vegetales. Así, Moffet y Wood (1984) recuperaron la 
bacteria a partir de tejido vegetal infectado que fue enterrado en el campo durante 3 meses en suelo franco-arenoso y durante 7 meses en suelo franco-arcilloso.

Los estudios de supervivencia realizados por Chang et al. (1990) determinaron que el patógeno pudo recuperarse, en asociación con tallos de tomate, tras 196 días desde la infección. Estos tallos fueron situados a distintas profundidades en el terreno. Como resultados, se obtuvo que el ratio de supervivencia fue superior en superficie pero no se observaron diferencias a 10, 20 y $30 \mathrm{~cm}$ de profundidad.

Fatmi y Schaad (2002) centraron su investigación en la asociación de la bacteria a los tallos de tomate en condiciones de campo, comprobando de nuevo que la supervivencia del patógeno disminuía si los restos de tallo se enterraban en el suelo.

También es importante la transmisión de la bacteria a través de las semillas (Shoemaker y Echandi, 1976; Tsiantos, 1987). Este modo de dispersión se debe a que el patógeno permanece en la superficie de las semillas, sin existir infección interna. Del mismo modo, hay que considerar la posible transmisión por medio de las plántulas donde C. m. michiganensis puede permanecer en estado latente, esperando las condiciones adecuadas. La dispersión se puede favorecer durante la manipulación de los cultivos (defoliaciones, podas, recolección, etc.). Una vez se detecta la enfermedad, las plantas afectadas deben de ser destruídas y, en el campo, las zonas donde ha aparecido deben aislarse (OEPP/EPPO, 2005).

Entre los métodos de control, se indica el tratamento químico con $\mathrm{BM}$ (Munnecke y Ferguson, 1960; Strider, 1967). De León et al. (2008) compararon la eficiencia de distintos compuestos químicos concluyendo que el sulfato de cobre combinado con 8-hidroxi-quinolina podría controlar los síntomas externos de chancro bacteriano, en condiciones de invernadero, protegiendo el medioambiente al reducir la cantidad de cobre aplicada a los cultivos.

Según Jones et al. (1991) el empleo de semillas y trasplantes limpios es el principal método de control, de modo que recomiendan la desinfección de semillas 
con hipoclorito sódico, hipoclorito cálcico o agua caliente, al igual que proponían Shoemaker y Echandi (1976). En el caso de invernaderos tanto el suelo como las macetas deben desinfectarse. Las herramientas de trabajo han de ser igualmente desinfectadas durante y al final de su uso. Las estacas puede librarse del patógeno con vapor de agua o con soluciones de hipoclorito sódico. En el caso de detectarse suelos enfermos en el campo, las plantas de tomate han de incorporarsse al terreno para favorecer la descomposición de los restos y se recomienda la rotación de cultivos incluyendo plantas no huéspedes de C.m.michiganensis.

Tras el estudio realizado por Gleason et al. (1991), donde demuestran que la asociación del patógeno con restos de cosecha puede reducir de forma significativa los rendimientos de cultivos de tomate posteriores, los autores sugieren como medida de control la rotación de cultivos sin emplear tomates durante un periodo de tiempo no inferior a un año.

Jahr et al. (1999) indicaron que el control químico de la enfermedad usando antibióticos o compuestos de cobre no resulta muy eficiente y, además, su empleo supondría importantes problemas medioambientales y tampoco el uso de cultivares resistentes ha resultado satisfactorio del todo. También Chang et al. (1991) sugieren las medidas de prevención empleando semillas totalmente sanas, certificadas y plántulas diagnosticadas libres del patógeno.

La solarización también ha sido ensayada para el control del chancro bacteriano del tomate (Antoniou et al., 1995), resultando efectiva en el caso de invernaderos. Para ello, el suelo se cubrió con láminas de PE transparente durante unas 6 semanas reduciéndose de forma drástica la incidencia de la enfermedad y, además, se obtuvieron mejores resultados que con el tratamiento con BM (aplicado en dosis de $70 \mathrm{~g} \mathrm{~m}^{-2}$ ) que no fue efectivo.

Según estudios realizados en España por Elorrieta et al. (2006), entre las medidas tomadas para el control de la enfermedad ante el grave episodio de la misma acontecido durante el otoño de 2002 en Andalucía, Canarias y el Levante español, lo más común fue la eliminación de plantas enfermas, el aislamiento de 
los focos y la desinfección de herramientas con hipoclorito sódico. Al finalizar el cultivo, se eliminaban las plantas, incluyendo raíces, y se aplicaron tratamientos químicos al suelo y estructuras y/o se solarizó de modo que el resultado final fue efectivo en casi todos los casos. Así, de todas las fincas afectadas sólo un $2 \%$ volvió a mostrar síntomas en la campaña siguiente.

\subsubsection{Metodología de diagnóstico}

La infección sistémica de la bacteria puede detectarse sumergiendo un trozo de tallo afectado en agua, de modo que emerge el exudado bacteriano adquiriendo la suspensión un aspecto lechoso en muy pocos minutos. La OEPP/EPPO (2005) describe la metodología de diagnóstico incluyendo las técnicas ELISA, PCR y tests de patogenicidad.

Son numerosos los estudios sobre medios nutritivos que permitan un aislamiento fácil de la bacteria (Kado y Heskett, 1970; Fatmi y Schaad 1985; Dhanvantari, 1987; Fatmi y Schaad, 1988) a partir de material vegetal infectado.

Por su parte, De León et al. (2006) compararon la eficacia de las técnicas de detección tradicionales (serológicas, moleculares y de aislamiento) con la innovadora técnica de separación inmunomagnética (IMS) que permite detectar C.m.michiganensis subsp. michiganensis en semillas de tomate. Como resultado, la IMS demostró la mayor sensibilidad y especificidad al favorecer un aislamiento selectivo y permitir la caracterización de los diferentes aislados y la verificación de su poder patógeno.

\subsection{Mycosphaerella brassicicola}

Una de las enfermedades foliares más importantes que afectan a las brassicas es la conocida como "mancha en anillo" del inglés "Ring spot disease" y que está causada por el hongo Mycosphaerella brassicicola (Duby) Lindau (Kennedy et al., 1999; Van den Ende, 1993a). Su presencia en los cultivos de brassicas queda restringida a aquellas zonas que presentan unas condiciones de 
elevadas humedades y temperaturas moderadas, comprendidas entre 5 y $20{ }^{\circ} \mathrm{C}$ (Daly y Tomkins, 1995; Van den Ende 1993a; Van den Ende, 1993b). Durante un periodo de epidemia, el patógeno se disemina desde los restos de cultivo que quedan en el suelo (sobre el mismo o incorporados a éste) o de forma más directa, desde cultivos ya maduros a otros colindantes.

M. brassicicola sólo puede persistir en el suelo en asociación con restos de cultivo (UC Davis, 2007) y son tres las formas en las que el hongo inverna: en las partes de la planta que infecta, en los restos de cultivo y en semillas (Daly y Tomkins, 1995).

En condiciones de campo, las zonas más afectadas en Europa se localizan en los Países Bajos y, respecto a los ciclos de cultivo, las infecciones más severas se han observado entre la octava y décima semanas tras el trasplante de las plántulas de brassicas, así como al final de verano y principios del otoño, cuando las plantas en campo están totalmente desarrolladas y las condiciones climáticas resultan óptimas para el desarrollo de la enfermedad (Van den Ende, 1993a).

\subsubsection{Clasificación fúngica}

El patógeno responsable de la mancha en anillo en brassicas pertenece al Reino: Fungi; Phylum: Ascomycota; Clase: Dothideomycetes; Subclase: Dothideomycetidae; Orden: Capnodiales; Familia: Mycosphaerellaceae; Género: Mycosphaerella; Specie: M. brassicicola; Nombre binomial: Mycosphaerella brassicicola (Duby) Lindau (1897). El estado imperfecto (anamorfo): Asteromella brassicicola (Chev.) Boerema y Kersten (1964). El hongo es homotálico (Silué et al., 1999).

\subsubsection{Ciclo del patógeno}

En condiciones de campo la descarga de ascosporas puede tener lugar en un amplio rango de temperaturas comprendidas entre 0 y $26^{\circ} \mathrm{C}$ (Van den Ende, 1998). Sin embargo, en condiciones in vitro la máxima temperatura para la 
descarga de las ascosporas se sitúa en $22{ }^{\circ} \mathrm{C}$ (en caso de trabajar siempre con aislados holandeses). En hojas secas los cuerpos fructíferos necesitan entre 24 y 48 horas tras su humedecimiento para la descarga.

En cuanto al tiempo requerido para la germinación de estas ascorporas también depende, principalmente, de la humedad y, respecto a las condiciones térmicas, la mayoría de las esporas necesitan 48 horas en un rango de temperaturas entre 18 y $22{ }^{\circ} \mathrm{C}$, mientras que a bajas temperaturas cercanas a $7^{\circ} \mathrm{C}$ la germinación tiene lugar tras unas 96 horas. Una vez germinadas las ascosporas, las hifas colonizan el huésped a través de los estomas tras largos periodos de humedad elevada o humedeciendo las hojas (Götz et al., 1993).

Para la formación de los cuerpos fructíferos, de nuevo la temperatura es un factor importante. El hongo forma espermogonios en un rango entre 0 y $22{ }^{\circ} \mathrm{C}$ y esta fase del ciclo es independiente de la humedad. Sin embargo, al menos 4 días con humedades elevadas (> 98\%) y temperaturas entre 8 y $20{ }^{\circ} \mathrm{C}$ se necesitan para la formación de pseudotecios. En condiciones in vitro la producción de ascosporas de $M$. brassicicola depende de la variación de temperatura e iluminación (Götz et al., 1993; Kennedy et al., 1999).

\subsubsection{Sintomatología relacionada}

Las lesiones causadas por M. brassicicola sólo aparecen en las partes aéreas de las plantas afectadas. Las manchas en anillo son el tipo de lesión más común con forma circular y márgenes definidos. Estas lesiones muestran una coloración característica marrón-negruzca y desarrollan espermogonios y pseudotecios.

La dispersión de la enfermedad y posterior infección de plantas depende de la producción de ascosporas dentro de los pseudotecios. $M$. brassicicola produce un micelio filamentoso de coloración grisácea-blanquecina cuando se hace crecer en medio con agar (Kennedy et al., 1999). 
Tras la infección de las hojas, el patógeno requiere de periodos relativamente largos (de 10 a 28 días) de humedad en la superficie de las mismas para el desarrollo de pseudotecios y producción de ascosporas (Kennedy et al., 1999). Los pseudotecios en las hojas aparecen en ambas caras y, con frecuencia, forman anillos concéntricos y liberan las ascosporas cuando maduran. Estas, a su vez, se diseminan con el viento llegando a alcanzar distancias considerables (Kennedy et al., 2000).

Los cuerpos fructíferos conteniendo ascosporas maduras se forman, mayoritariamente, en hojas viejas y que adquieren coloraciones amarillentas (Van den Ende, 1998). Las lesiones que aparecen en frutos y tallos se caracterizan por su color negro, por su forma irregular y no esporulan.

Las infecciones más severas provocan un adelanto de la senescencia de las hojas e importantes defoliaciones, de modo que estos daños son responsables de importantes pérdidas económicas al afectar al rendimiento de los cultivos. $M$. brassicicola también supone problemas serios en condiciones de almacenaje ya que las lesiones que causa se convierten en puntos de entrada para patógenos secundarios y, además, las manchas en anillo continúan creciendo aún en condiciones de bajas temperaturas $\left(0-5{ }^{\circ} \mathrm{C}\right)$ aumentando la severidad de la enfermedad durante las condiciones de almacenamiento (Van den Ende, 1998).

\subsubsection{Fuentes de inóculo, control y prevención}

La capacidad de dispersión del patógeno desde cultivos altamente infectados a otros recién trasplantados, es la forma de inóculación que requiere un mayor control para evitar la enfermedad (Kennedy et al., 1999; Van den Ende, 1998).

El empleo de productos químicos contra $M$. brassicicola incluye el uso de benzimidazoles (como benomilo y carbendazima), pyrifenox, oxicloruro de cobre e hidróxido cúprico ya que se ha observado que proporcionan altos niveles de control cuando se aplican en campo al observarse los primeros síntomas o tras 
periodos de riesgo con altas humedades (Daly y Tomkins, 1995; Sherf y MacNab, 1986; Van den Ennde, 1998).

Las restricciones sobre las aplicaciones y el desarrollo de resistencias son las principales limitaciones en el uso de fungicidas. Por ejemplo, bajo la legislación holandesa, una de las zonas más afectadas en Europa debido a las condiciones ambientales óptimas para el desarrollo de la enfermedad, el número de aplicaciones de fungicidas contra la mancha en anillo quedó restringida a dos tratamientos con benzimidazoles y/o una vez pirifenox para cada ciclo de cultivo (Van den Ende, 1998).

Continuando con los tratamientos químicos, Wicks et al. (1987) para combatir las poblaciones de $M$. brassicicola resistentes al empleo de carbendazima y de otros benzimidazoles que afectaron a cultivos de coles de Bruselas en el sur de Australia, emplearon clortalonil, fenarimol, pencozanol y triadimeton, obteniendo buenos resultados.

Para controlar la transmisión a través de las semillas, estas pueden ser tratadas con agua caliente ya que las esporas del hongo se mueren a $28{ }^{\circ} \mathrm{C}$. Además, los cultivos deberían establecerse sólo en aquellos campos que hayan permanecido libres de crucíferas por lo menos durante dos años (Sherf y MacNab, 1986).

La búsqueda de resistencias, las medidas sanitarias y el desarrollo de técnicas de biocontrol, aplicadas solas o en combinación con fungicidas, se encuentran entre las estrategias de control de la enfermedad. En este sentido, en Inglaterra, se han desarrollado cultívares de coles de Bruselas resistentes como el cultivar Moases (Van den Ende, 1998), mientras que los efectos de defoliación y la mejor combinación de defoliantes con fungicidas también han sido ensayadas y recomendadas (Lorezco y Mariano, 2003).

Para el control de la enfermedad también se aconseja la incorporación en el suelo de los restos de cosecha con la finalidad de que el material infectado se descomponga por completo, el retirar las plantas que pudieran haberse infectado, el 
empleo de trasplantes libres de la enfermedad y el uso de fungicidas que protejan antes de que la infección tenga lugar, siempre y cuando la mancha en anillo sea un problema en la zona (UC Davis, 2007). 



\section{JUSTIFICACIÓN Y OBJETIVOS}

El presente trabajo se planteó tratando de obtener resultados sobre la eficacia de la aplicación de las técnicas de biofumigación y de su combinación con solarización en el control de bacterias fitopatógenas. Para ello se seleccionaron dos de las bacterias fitopatógenas cuya presencia supondría elevados riesgos en los cultivos, principalmente hortícolas, y que podrían ver mermado su rendimiento.

Las bacterias seleccionadas fueron Ralstonia solanacearum y Clavibacter michiganensis subsp. michiganensis. La selección se realizó considerando dos criterios: el primero de ellos es la inclusión de ambas bacterias en la lista A2 de patógenos de cuarentena por la EPPO por lo que su presencia se hace potencialmente peligrosa exigiendo tratamientos drásticos y soluciones rápidas. El segundo de los criterios seguidos se basó en la ineficacia de los tratamientos químicos empleados en su control, en especial del BM, y ante la necesidad de búsqueda de alternativas menos nocivas para el medioambiente.

Una vez elegidas las bacterias, y teniendo en cuenta que ambas habían presentado focos de infección en diferentes áreas de cultivo de tomate, se planteó la necesidad de estudiar detenidamente los efectos de las técnicas de control seleccionadas buscando su eliminación en asociación con los restos de cosecha, por lo que toda la parte experimental se diseñó para su realización en condiciones controladas, de invernadero y laboratorio, antes de poder aplicarlas en campo, recordando de nuevo el elevado riesgo que supone la experimentación en campo con bacterias de cuarentena.

Previo al diseño de las técnicas de biofumigación y biosolarización, se llevó a cabo un estudio del comportamiento de los aislados bacterianos en el cultivo seleccionado, es decir, se convino conocer el alcance que supondría su presencia en plantas de tomate cv. Money-Maker. Esto nos permitiría graduar la agresividad y virulencia de los aislados proporcionados e identificar de forma precisa la sintomatología asociada a los patógenos. 
Las técnicas de control en estudio fueron la biofumigación y su combinación con solarización empleando restos de cosecha de tomate, ya que, aunque el efecto de las brassicas ha sido ampliamente estudiado, en España y mayoritariamente en el sureste peninsular, se generan toneladas de otros restos hortícolas, principalmente de pimiento y tomate, que podrían tener actividad biofumigante. Su incorporación en el suelo no sólo supondría una solución a la contaminación ambiental, sino que se eliminaría una de las principales fuentes de reinfectación de cultivos.

Continuando con el estudio del efecto de los restos de cosecha como potencial fuente de inóculo, la segunda parte de este trabajo consiste en la aplicación de control biológico contra el hongo Mycosphaerella brassicicola en cultivos de coles de Bruselas, con el objetivo de reducir el empleo de productos químicos. Se trata de un ensayo en campo, realizado en Holanda durante el periodo requerido de estancia en un centro de investigación extranjero, permitiendo el trabajo con hongos al ser los patógenos manejados en el grupo de investigación seleccionado. Se persigue controlar las fuentes de inoculación secundarias, como son los restos de cultivo de crucíferas que quedan sobre la superficie del suelo y, para ello, se compararon distintos tratamientos que incluían desde acelerantes de la descomposición, a defoliantes y agentes de control biológico.

Esta segunda parte añade nuevas perspectivas de futuro al trabajo inicial realizado con bacterias, ya que la metodología aplicada se podría adaptar a los ensayos expuestos mejorando la detección y cuantificación de patógenos. 


\section{MATERIAL Y MÉTODOS}

\section{Biofumigación y biosolarización en condiciones controladas}

\subsection{Medios de cultivo y crecimiento de cepas bacterianas}

Se emplearon dos cepas bacterianas de $R$. solanacearum y C.m.michiganensis procedentes de cultivos de tomate afectados. En 2003, se reciben en el laboratorio de Virología Vegetal de la Universidad Politécnica de Valencia las bacterias crecidas en placas Petri conteniendo medios nutritivos generales. Los cultivos fueron solicitados a zonas donde en alguna ocasión esporádica se habían detectado las enfermedades de marchitamiento y chancro bacterianos, con la finalidad de manejar los aislados adaptados a las condiciones ambientales de los campos españoles. El trabajo comenzó reviviendo los cultivos puros, continuando con el ensayo de los medios selectivos más adecuados y con la selección de las condiciones óptimas de crecimiento. Como medio general de crecimiento se disponía de YDA (del inglés "Yeast Dextrose Agar", Agar de levadura con dextrosa) preparado a partir de 23,5g de Agar 3 (Plate count agar Standard Methods Agar) de la marca comercial DIFCO, en un litro de agua, autoclavado y volcado en placas Petri.

\subsubsection{Ralstonia solanacearum}

Las colonias bacterianas se hicieron crecer en un medio modificado de cloruro de trifeniltetrazolio TTC (Kelman, 1954; Kado y Heskett, 1970; Nesmith y Jenkins, 1979)

- $\quad 10 \mathrm{~g}$ de glucosa

- $10 \mathrm{~g}$ de peptona universal

- $1 \mathrm{~g}$ de caseína hidrolizada

- $18 \mathrm{~g}$ agar

- En 1 litro de agua destilada 
- Añadiendo $1 \mathrm{ml}$ de una solución al 1\% de cloruro de 2,3,5 trifeniltetrazolio esterilizado en autoclave por separado por cada $200 \mathrm{ml}$ de medio

Una vez preparado el medio y dispuesto en placas Petri, se realizaba la siembra bacteriana repicando de las placas madre (siempre en cabina de flujo laminar, con asas de siembra debidamente flameadas y manteniendo las condiciones de esterilidad) y se dejaban crecer durante $48 \mathrm{~h}$ a temperaturas cercanas a $30^{\circ} \mathrm{C}$ (Nesmith y Jenkins, 1979).

Los cultivos se mantenían en la estufa, en oscuridad, y se repicaban semanalmente. Todas las placas eran selladas con parafilm evitando la deshidratación del medio nutritivo.

\subsubsection{C.m.michiganensis}

Las colonias bacterianas se hicieron crecer en medio D2 (Kado y Heskett, 1970) modificado:

- $\quad 10 \mathrm{~g}$ de glucosa

- $\quad 4 \mathrm{~g}$ de caseína hidrolizada

- $\quad 2 \mathrm{~g}$ de extracto de levadura

- $1 \mathrm{~g} \mathrm{ClNH}_{4}$

- $\quad 0,3 \mathrm{~g} \mathrm{MgSO}_{4} 7 \mathrm{H}_{2} \mathrm{O}$

- $\quad 1,2 \mathrm{~g}$ Tris

- $15 \mathrm{~g}$ agar

- En 1 litro de agua destilada

Una vez preparado el medio y dispuesto en placas de Petri, se realizaba la siembra bacteriana de la misma forma que para la bacteria anterior: repicando de las placas madre (siempre en cabina de flujo laminar, con asas de siembra debidamente flameadas y manteniendo las condiciones de esterilidad) y se dejaban crecer durante $48 \mathrm{~h}$ a temperaturas cercanas a $28^{\circ} \mathrm{C}$ (Trevors y Finnen, 1990). 
Los cultivos también se mantenían en la estufa, en oscuridad, y se repicaban una vez a la semana. Todas las placas eran selladas con parafilm.

\subsection{Reacción de hipersensibilidad en hojas de tabaco}

Una vez al mes, se realizaban infiltraciones en los espacios intracelulares de hojas de tabaco con suspensiones bacterianas conteniendo $10^{8}$ UFC (Unidades Formadoras de Colonias) $\mathrm{ml}^{-1}$ para la determinación de la patogenicidad de los cultivos puros, basada en el desarrollo de necrosis internervial (Klement et al., 1964; Gitaitis, 1990).

Para la inoculación, la solución bacteriana se estandarizaba (para mantener cierta uniformidad) al estándar 0,5 de McFarland, que corresponde a aproximadamente $1,5 \times 10^{8} \mathrm{CFU} \mathrm{ml}^{-1}$ (Andrews, 2004), su preparación se indica a continuación:

$1,17 \mathrm{~g}$ de $\mathrm{BaCl}_{2} 2 \mathrm{H}_{2} \mathrm{O}$ en $100 \mathrm{ml}$ de agua destilada (A)

$1 \mathrm{ml} \mathrm{de} \mathrm{H}_{2} \mathrm{SO}_{4}$ en $100 \mathrm{ml}$ de agua destilada (B)

Mezclar 0,5 ml de A con 99,5 ml de B

Distribuir en tubos del mismo tamaño y con capacidad para el mismo volumen y sellarlos para evitar pérdidas por evaporación. Se recomiendan alicuotas entre 4 y $6 \mathrm{ml}$.

Almacenar (hasta un máximo de 6 meses) a temperatura ambiente (entre 22 y 25 $\left.{ }^{\circ} \mathrm{C}\right)$ y en oscuridad

Antes de cada uso, agitar bien mezclando el precipitado blanquecino del sulfato de bario

Una vez preparado el estandard 0,5 de McFarland, la correcta densidad de turbidez ha de verificarse. Para ello se empleaba el método de las diluciones seriadas (Figura 5).

Para el caso del estandard 0,5 de McFarland el procedimiento seguido se recoge a continuación:

- Ajustar una suspensión bacteriana a la turbidez del standard 
- Mezclar $1 \mathrm{ml}$ de muestra en $9 \mathrm{ml}$ de agua fisiológica estéril (A) (1/10) y sembrar en placa $100 \mu 1$ en placa Petri

- Mezclar 0,5 ml de la dilución A en otros 4,5 ml de agua fisiológica estéril (B) $\left(1 / 100\right.$ ó $\left.10^{-2}\right)$ y sembrar $100 \mu$ l en placa Petri

- Mezclar 0,5 ml de B en 4,5 ml de agua fisiológica estéril $\left(10^{-3}\right)$ y de nuevo sembrar; así sucesivamente

- Conteo de colonias

Las suspensiones bien ajustadas deben dar un resultado de $10^{8} \mathrm{UFC} \mathrm{ml}^{-1}$

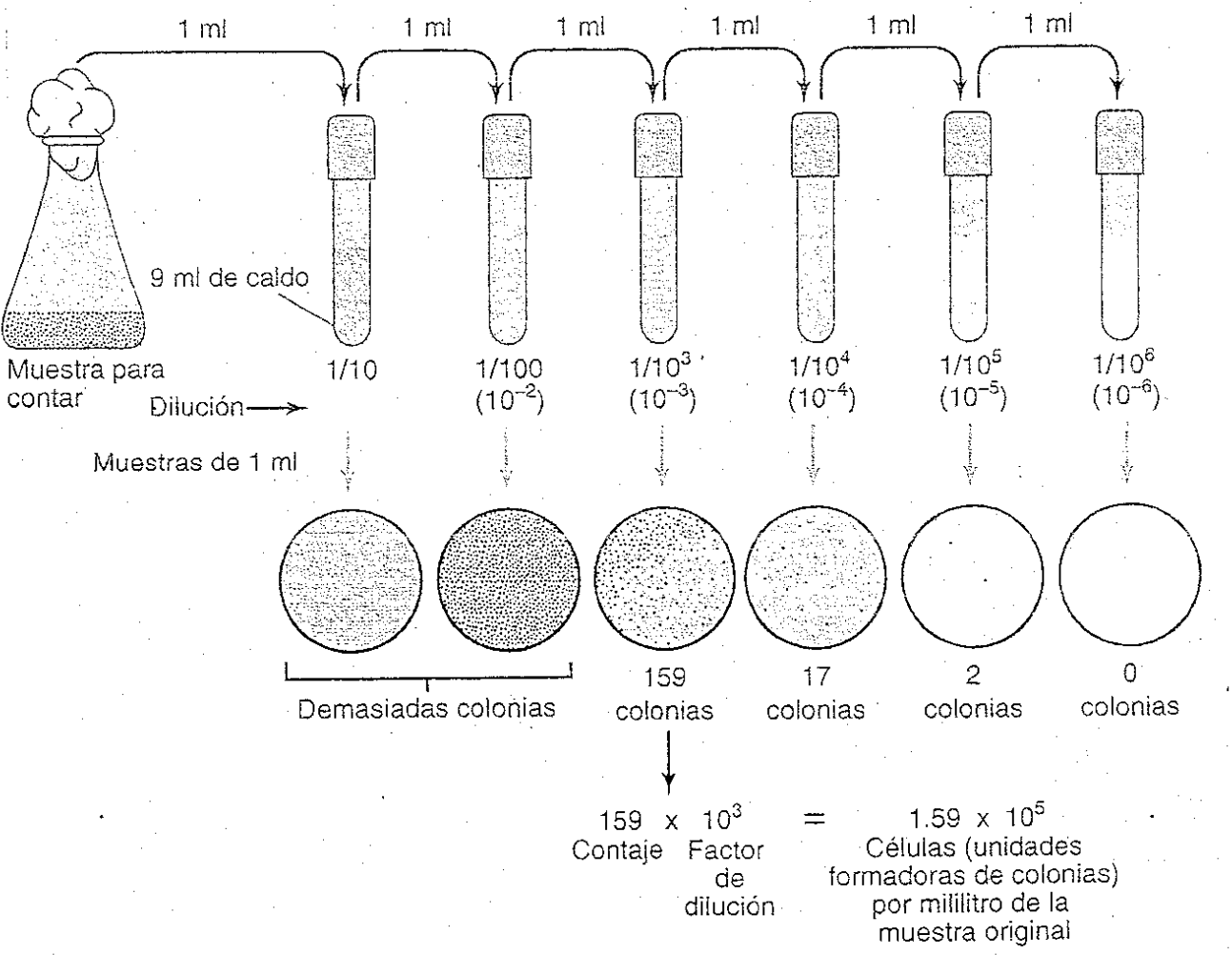

Figura 5. Método de las diluciones seriadas (Fuente: Madigan et al., 1998) 
Una vez preparadas y ajustadas, las soluciones bacterianas se inoculaban en los espacios internerviales de las hojas de tabaco, empleando jeringuillas y agujas estériles que se cambiaban al cambiar de solución. Las plantas de tabaco tenían una edad mínima de 15 días, para facilitar la inoculación así como la observación de síntomas y se mantenían siempre en condiciones de invernadero. Todos los ensayos de invernadero se realizaban en condiciones de aislamiento en las instalaciones de la Universidad Politécnica de Valencia.

\subsection{Inoculación en plantas de tomate: infección controlada}

La inoculación de plantas de tomate se realizaba con tres objetivos: para la obtención de material vegetal artificialmente infectado, para comprobar la virulencia de las cepas bacterianas en plantas huéspedes y para la identificación de síntomas.

A continuación se indica la metodología de inoculación en plántulas de tomate del cultivar Money-Maker, cuyas semillas fueron previamente sometidas a un tratamiento térmico durante $24 \mathrm{~h} \mathrm{a} 80{ }^{\circ} \mathrm{C}$ :

- Las plántulas se dejaban crecer en condiciones semicontroladas de invernadero hasta llegar al estadío de 4 hojas expandidas

- Ajuste de soluciones bacterianas a $10^{8} \mathrm{UFC} \mathrm{ml}^{-1}$ según el estandard 0,5 de McFarland

- Empleo de agujas y jeringuillas estériles conteniendo unos $30 \mu \mathrm{l}$ de solución

- Introducción de la aguja produciendo microheridas en las axilas de las hojas (hasta 3 heridas por plántula)

- Deposición de una gota de solución en la zona dañada

- Cubrimiento con algodón estéril, a su vez impregnado con la solución bacteriana

- Tapado con parafilm permitiendo el desarrollo de una infección sistémica

- Las plantas inoculadas se mantenían bajo condiciones de invernadero a temperaturas comprendidas entre $18-30^{\circ} \mathrm{C}$ 
- Los síntomas se evaluaban transcurridos 15 días tras la inoculación

- La presencia de la bacteria se confirmaba mediante observación visual de síntomas y usando la técnica serológica DAS-ELISA empleando los antisueros específicos para las bacterias en estudio: No. 07063 de Loewe para C.m.michiganensis y No. 07056 también de Loewe para $R$. solanacearum (Loewe Biochemica GmbH, Sauerlach, Germany). La metodología de la técnica serológica seleccionada se indica a continuación.

\subsubsection{Técnica serológica Double Antiserum Sandwich- Enzyme Linked Immunosorbent Assay (DAS-ELISA)}

De acuerdo con Sánchez-Vizcaíno y Cambra (1981) la técnica serológica se realizó mediante la adición secuencial de una serie de reactivos, separados por etapas de lavado. Se utilizaron, como soporte insoluble o inmunoadsorbente, placas de poliestireno de 96 pocillos de lectura y se siguió el protocolo de la casa comercial Loewe, suministradora de los antisueros de C.m.michiganensis y $R$. solanacearum. Para ello, previamente, se prepararon los tampones que serían requeridos en cada una de las etapas:

1- Tampón coating o de tapizado:

- $1,86 \mathrm{~g} \mathrm{Na}_{2} \mathrm{CO}_{3} \mathrm{H}_{2} \mathrm{O}$

- $\quad 2,93 \mathrm{~g} \mathrm{NaHCO}_{3}$

- $1000 \mathrm{ml}$ agua destilada

- $\mathrm{pH} 9,6$

2- Tampón de lavado:

$-8 \mathrm{~g} \mathrm{NaCl}$

- $\quad 1,15 \mathrm{~g} \mathrm{Na}_{2} \mathrm{HPO}_{4}$

- $\quad 0,2 \mathrm{~g} \mathrm{KH}_{2} \mathrm{PO}_{4}$

- $\quad 0,5 \mathrm{ml}$ tween 20 
- $1000 \mathrm{ml}$ agua destilada

- $\mathrm{pH} 7,2$ a 7,4

3- Tampón conjugado y de extracción (se empleó el mismo)

- 20g PVP (Polivinilpirrolidona)

- 2g BSA (albúmina de suero bovino)

- $\quad 0,1 \mathrm{~g} \mathrm{NaN}_{3}$

- $1000 \mathrm{ml}$ de tampón de lavado

$-\mathrm{pH} 7,4$

4- Tampón substrato:

- $\quad 97 \mathrm{ml}$ dietanolamina

$-0,2 \mathrm{~g} \mathrm{MgCl}_{2} \cdot 6 \mathrm{H}_{2} \mathrm{O}$

- en $903 \mathrm{ml}$ de agua destilada

- $\mathrm{pH} 9,8$

Una vez preparados los tampones, excepto el de lavado que se dejaba a temperatura ambiente, se mantenían en nevera a $4{ }^{\circ} \mathrm{C}$.

El procedimiento de la técnica DAS-ELISA se recoge a continuación:

- Dilución del antisuero (IgG) en una proporción 1/200 en el tampón de tapizado añadiendo $100 \mu 1$ en cada pocillo de la placa de poliestireno. Las placas se incubaban durante 4 horas a $37^{\circ} \mathrm{C}$.

- Transcurridas la 4 horas las placas se lavaban con tampón de lavado siguiendo instrucciones de la casa comercial: dos lavados cortos que suponían adición del tampón de lavado a los pocillos y retirada inmediata, y un tercer lavado dejando actuar al tampón durante tres minutos antes de retirarlo.

- Adición de las muestras: las muestras vegetales se homogeneizaban en tampón de extracción en una proporción de $1 / 20$, y se añadían $100 \mu$ l a los pocillos. Para las lecturas se precisaban de controles positivos y negativos: como control 
negativo se empleaban hojas de tomate completamente sanas que se homogeneizaban en tampón de extracción de forma similar al resto de muestras. Como controles positivos se empleaban soluciones bacterianas en agua fisiológica estéril preparadas directamente de las placas de cultivos puros. Como blanco (pocillo sobre el que lee el espectrofotómetro) se empleaba tampón de lavado, al considerarse importante el uso de uno de los tampones arrastrados durante la aplicación de la técnica anticipando la detección de posibles contaminaciones.

- Tras la adición de las muestras las placas se incubaban durante toda la noche a $4{ }^{\circ} \mathrm{C}$, formándose el complejo antígeno-anticuerpo. Al día siguiente se lavaban 3 veces con tampón de lavado, de nuevo dos lavados rápidos precedían al tercero de tres minutos antes de retirar el tampón, consiguiendo eliminar los restos de muestra no fijados y los antígenos que no reaccionaran.

- Adición de anticuerpos conjugados con fosfatasa alcalina: la IgG conjugada se diluía en tampón conjugado en una proporción $1 / 200$ y se añadían $100 \mu$ l por pocillo. Las placas se incubaban durante 4 horas a $37{ }^{\circ} \mathrm{C} \mathrm{y}$, transcurrido este tiempo, se lavaban de nuevo con la secuencia de tres lavados expuesta en pasos anteriores.

- Adición del susbstrato sobre el que actúa la fosfatasa alcalina: se añadían $100 \mu 1$ por pocillo de una disolución de p-nitrofenil fosfato (de Sigma Chemicals) en tampón substrato en una proporción de $1 \mathrm{mg} / \mathrm{ml}$ y se dejaba incubar a temperatura ambiente hasta reaccionar

- Lectura de las placas: se realizaba en un espectrofotómetro (Multiskan plus) midiendo la absorbancia de cada muestra a una longitud de onda de $405 \mathrm{~nm}$. La primera de las lecturas se realizaba a los 15 minutos desde la adición del substrato y la última a los 60 minutos. 
En los análisis serológicos realizados para la detección de bacterias se consideraron como positivas las muestras cuya absorbancia superaba en dos veces la media de las absorbancias de los controles negativos.

\subsection{Microscopía Electrónica de Barrido (SEM)}

Con el objetivo de comprobar la adecuada infección de las plantas, así como el comportamiento de las bacterias en el interior de los huéspedes, tras las primeras inoculaciones se observaron las interacciones ultraestructurales entre las bacterias patógenas y los tejidos vegetales afectados por su introducción. Para ello se empleó la microscopía electrónica de barrido SEM (Jeol JSM-5410 Scanning Microscope) en el "Servicio de Microscopía de la Universidad Politécnica de Valencia" bajo la supervisión del servicio técnico de la universidad. De este modo se observaron la presencia y efecto de los patógenos bacterianos en el interior de las plantas de tomate (Hagen et al., 1968; Huang, 1986). En el SEM se hace incidir un delgado haz de electrones acelerados sobre una muestra opaca a los electrones. Este haz se focaliza sobre la superficie de la muestra de forma que realiza un barrido de la misma siguiendo una trayectoria de líneas paralelas. Cuando la muestra no es buena conductora se acostumbra a recubrirla con una película conductora metálica o de carbono para evitar que esta se cargue cuando sea irradiada.

Las muestras se prepararon partiendo de fragmentos de plantas de tomate, de aproximadamente $0,5 \mathrm{~cm}$ de longitud, que se fijaban directamente a los portaobjetos específicos, y se procedía con la metodología previa a su observación. Debido a la naturaleza de las muestras estas debían ser recubiertas superficialmente por un film conductor de electrones; en este trabajo fueron recubiertas mediante un film de oro. Previamente, las muestras se secaron tras su paso por nitrógeno líquido y posterior sublimación debido al elevado vacío que debe ser suministrado a la columna del microscopio para permitir que los 
electrones migren de su fuente de emisión con una energía suficiente para interaccionar con la superficie de la muestra de tomate y poder dar señales.

\subsection{Tratamiento en macetas: adición de restos de tomate como enmienda orgánica}

Para el experimento se emplearon restos vegetales de tomate, variedad Money-Maker precisando de grandes cantidades de este material infectado artificialmente con las bacterias en estudio y las mismas cantidades de material totalmente sano que se emplearían como control. La obtención del material infectado se realizó siempre siguiendo la metodología expuesta en el apartado 1.3. Una vez preparado el material vegetal, y comprobada su infección con la bacteria, se procedía con el ensayo en macetas.

\subsubsection{Diseño de la experiencia de biofumigación y biosolarización en condiciones de invernadero}

Para el experimento se emplearon restos vegetales de tomate infectados que se introdujeron en macetas (de $15 \mathrm{~cm}$ de diámetro y $15 \mathrm{~cm}$ de altura) que contenían 500g de substrato preparado mezclando turba y arena gruesa de sílice en una proporción 4:1 (v/v) favoreciendo el drenaje. Respecto a las características de la turba empleada, se trataba de un substrato de cultivo a base de turbas de la marca comercial Gramoflor (Gramoflor Vertriebs gmbH and Co., Alemania): enmienda orgánico natural, turba neutra "bruna di sfagno", con un contenido en carbono orgánico de origen biológico del $35 \%$, nitrógeno orgánico $0,3 \%$, sustancia orgánica $60 \%$ y con $\mathrm{pH}$ de 6,0 .

El substrato se desinfectaba en autoclave, previamente a su uso, durante $1 \mathrm{~h}$ a $121{ }^{\circ} \mathrm{C}$ y se disponía en las macetas.

Las plantas de tomate artificialmente infectadas con las bacterias en estudio, se cortaban y se mezclaban con el substrato ensayándose tres dosis diferentes de material vegetal: $5 \mathrm{~g}, 10 \mathrm{~g}$ y $15 \mathrm{~g}$ por cada $500 \mathrm{~g}$ de substrato y con 
cuatro repeticiones. Del mismo modo se prepararon los controles negativos, de modo idéntico pero empleando material vegetal sano, o sólo el substrato sin adición de material vegetal y que se consideraba como dosis 0 .

Estas dosis fueron elegidas en relación con la biomasa de las plantas de tomate, de modo que trasladando el ensayo a campo los $5 \mathrm{~g}, 10 \mathrm{~g}$ y $15 \mathrm{~g}$ por cada $500 \mathrm{~g}$ de substrato corresponderían con 25, 50 y 100 tn de material vegetal por hectárea, respectivamente, ajustando las cantidades a las indicadas por Bello et al. (2003).

Se diseñaron 7 grupos de macetas, formado cada uno por 56 macetas, coincidiendo con las semanas de tratamiento térmico al que iban a someterse (desde 0 hasta 6). En cada uno de los ensayos la mitad de las macetas (12 macetas conteniendo material vegetal infectado, 12 macetas conteniendo material vegetal sano y 4 macetas sin material vegetal añadido) se encerraban en bolsas de plástico en condiciones herméticas y evitando la salida de las sustancias volátiles generadas durante el proceso de descomposición de la materia orgánica. Estas bolsas eran de PE térmico transparente, de 300 galgas de espesor y de un tamaño de 25 x $40 \mathrm{~cm}$. Las macetas dispuestas en bolsas se rotulaban con una B (de bolsa) mientras que las que permanecían abiertas se identificaban como NB (sin bolsa). El esquema de preparación y distribución de macetas se recoge en la figura 6 .

Las temperaturas ensayadas a las que se sometían los lotes de macetas, para estudiar la supervivencia de las bacterias patógenas, fueron $25^{\circ} \mathrm{C}$ y $45^{\circ} \mathrm{C}$ (Basu, 1970). Estas temperaturas se seleccionaron ya que una temperatura media de $25{ }^{\circ} \mathrm{C}$ se puede alcanzar fácilmente en condiciones de campo debido a las condiciones climáticas en España. Además, la técnica de biofumigación aplicada en campo puede combinarse con otras, como con la solarización, cubriendo la superficie del terreno con una lámina plástica y, en este caso, las temperaturas del suelo en condiciones de campo podrían alcanzar, e incluso superar, $\operatorname{los} 45^{\circ} \mathrm{C}$. 


\section{6 macetas Macetas no embolsadas Macetas embolsadas}

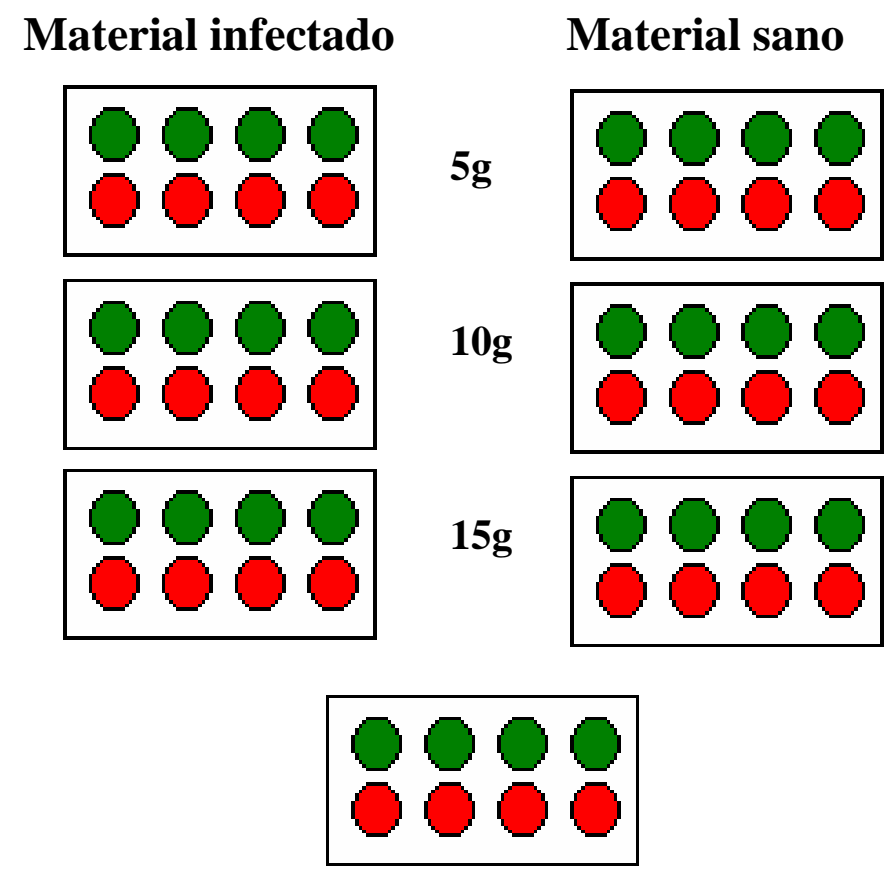

Sólo substrato

Figura 6: preparación de los lotes de macetas para ser sometidas a los tratamientos térmicos

Una vez preparadas, todas las macetas (las 56 por cada lote o "semana de tratamiento") se colocaban en estufas a las temperaturas experimentales. Transcurridos los periodos de tratamiento, el lote se sacaba de la estufa y todas las macetas se trasladaban al invernadero, donde permanecerían en condiciones semicontroladas de humedad y temperatura $\left(18-30^{\circ} \mathrm{C}\right)$. Nada más sacarlas, en cada una de las macetas se trasplantaba una plántula de tomate, cv. Money-Maker de 
dos semanas de edad, totalmente sana, crecida sobre substrato desinfectado y usada como trampa biológica. Posteriormente, las macetas se regaban hasta la saturación.

El efecto de los tratamientos se evaluaba transcurridos 40 días desde el trasplante. Para ello todas las plantas, con y sin síntomas de enfermedad bacteriana, se analizaban mediante la técnica serológica DAS-ELISA, como se ha descrito en el apartado 1.3.1. Cuando los análisis mostraban resultados negativos para todas las plantas a la presencia de la bacteria correspondiente, se consideraba que el patógeno no había infectado las plantas y que, por lo tanto, las poblaciones bacterianas habían sido reducidas, al menos, por debajo del límite de detección de la técnica de diagnóstico empleada. Sin embargo, bajos niveles patogénicos podrían permanecer todavía en asociación con el substrato (Noble y Roberts, 2004).

En total se ensayaron:

- 7 lotes de 56 macetas correspondientes a los tratamientos (desde 0 hasta 6 semanas) para C.m.michiganensis a $25^{\circ} \mathrm{C}$

- 7 lotes de 56 macetas correspondientes a los tratamientos (de 0 hasta 6 semanas) para R.solanacearum a $25^{\circ} \mathrm{C}$

- 7 lotes de 56 macetas correspondientes a los tratamientos (desde 0 hasta 6 semanas) para C.m.michiganensis a $45^{\circ} \mathrm{C}$

- 7 lotes de 56 macetas correspondientes a los tratamientos (de 0 hasta 6 semanas) para R.solanacearum a $45^{\circ} \mathrm{C}$

- Las correspondientes repeticiones en los tratamientos de corte (de no detección bacteriana) para ambos patógenos, a las dos temperaturas de estudio y en diferentes estaciones del año (verano e invierno)

\subsubsection{Análisis estadísticos}

La incidencia de la enfermedad, expresada como porcentaje de plantas con resultado positivo a la técnica DAS-ELISA, se evaluaba mediante el análisis factorial ANOVA utilizando el programa Statgraphics Plus softwre 4.1. 
(Manugistics Inc., Rockville, MD,USA). Los datos comparando los controles con las macetas conteniendo restos infectados se analizaron con dosis, semanas de duración de tratamiento térmico y tratamiento de macetas (abiertas o cerradas) como factores fijos.

Las diferencias significativas se analizaron comparando medias mediante el test LSD (del ingles "Least Significance Difference") de Fisher $(\mathrm{P}<0,05)$. Los análisis de regresión se llevaron a cabo mediante el programa EXCEL (Microsoft Office, 2003).

\subsection{Introducción y recuperación de cepas bacterianas en sustratos infectados artificialmente}

Este experimento está basado en el realizado por Trevors y Finnen (1990) pero fue modificado, recogiéndose la metodología a continuación y mostrando un esquema en la figura 7 :

- Preparación de substrato autoclavado como se recoge en el apartado 1.5.1.

- Muestreo de 40g de substrato y se introdujeron en placas Petri de cristal previamente autoclavadas: se prepararon un total de 4 placas ( 2 por bacteria en estudio)

- Se añadieron $10 \mathrm{ml}\left(10^{6}\right.$ UFC $\left.\mathrm{ml}^{-1}\right)$ de solución bacteriana, preparada directamente a partir de las placas crecidas y removiendo con ayuda de una espátula estéril

- Se añadió agua destilada estéril hasta alcanzar un nivel de humedad cercano al $60 \%$

- Inmediatamente después se extrajo $1 \mathrm{~g}$ de substrato y se diluyó en $9 \mathrm{ml}$ de agua fisiológica estéril (8g de $\mathrm{NaCl}$ por litro de agua destilada) para el posterior recuento de viables aplicando el método de las diluciones seriadas (apartado 1.2.), extendiendo $100 \mu \mathrm{l}$ por la placa de medio (se ensayaron medios selectivos: TTC para $R$. solanacearum y D2 para C.m.michiganensis y se comparaba con YDA como medio general) 
- Se realizaban 5 diluciones (5 tubos de diluciones seriadas) y dos repeticiones de siembra para cada dilución: en total 4 placas por tubo de dilución ( 2 en medio selectivo y 2 en medio general) y por bacteria en estudio haciendo un total de 20 placas por bacteria

- Las 20 placas se incubaban invertidas a $25^{\circ} \mathrm{C}$ durante 7 días

- Se procedía a la identificación y conteo de las diferentes colonias crecidas en las placas

- Las cuatro placas de cristal (2 por bacteria) se sellaron con parafilm evitando la pérdida de humedad

- Una placa por bacteria se incubaba a $25^{\circ} \mathrm{C}$ y a $45^{\circ} \mathrm{C}$, respectivamente, durante 6 semanas

- Cada 7 días toda la metodología se repetía: se extraía $1 \mathrm{~g}$ de substrato por placa y se realizaban las siembras para posteriores conteos

En total se preparaban 40 placas semanales por bacteria, haciendo un total de 80 placas y con tratamientos térmicos desde 0 hasta 6 semanas:

- $\quad 10$ placas en YDA a $25^{\circ} \mathrm{C}$

- 10 placas en medio selectivo a $25^{\circ} \mathrm{C}$

- $\quad 10$ placas en YDA a $45^{\circ} \mathrm{C}$

- 10 placas en medio selectivo a $45^{\circ} \mathrm{C}$

Se realizaban conteos de las diferentes colonias observadas en las placas, identificando las bacterias patógenas en estudio por evaluación visual de la morfología (forma, tamaño, coloración, márgenes, etc.) y confirmando mediante la obtención de sus cultivos puros, que eran analizados por serología DAS-ELISA, con los antisueros específicos. Cuando el resultado era positivo, se procedía a la inoculación en hojas de tabaco como test de patogenicidad tras los tratamientos térmicos, siguiendo la metodología expuesta en el apartado 1.2. 
Algunas de las colonias seleccionadas en este ensayo fueron identificadas mediante la técnica PCR (Reacción en Cadena de la Polimerasa) descrita en apartados posteriores.

\subsection{Determinación de la supervivencia de los patógenos en asociación con tejidos vegetales}

Para la determinación de la supervivencia del patógeno en el suelo, pero en asociación con el material vegetal artificialmente infectado se diseñó un experimento basado en el trabajo de Basu (1970), pero con modificaciones, cuyo esquema se recoge en la figura 7 :

- se seleccionaron tres trozos de tallos de tomate infectados con las bacterias en estudio, confirmando la infección de las plantas observando síntomas (vasos necrosados) y mediante análisis serológicos

- los trozos de tallo se introdujeron en tubos de ensayo conteniendo $6 \mathrm{~g}$ de substrato estéril

- Se prepararon un total de 24 tubos por bacteria y fueron sellados con parafilm evitando la pérdida de humedad

- En grupos de 6 se colocaron en estufas a las temperaturas de estudio (a $25^{\circ} \mathrm{C}$ y $\left.45^{\circ} \mathrm{C}\right)$

- Cada semana se extraía un tubo (por bacteria y temperatura) de las estufas, se sacaban los restos de tomate y se lavaban con agua estéril para eliminar las partículas del suelo

- El material vegetal limpio se machacaba en mortero y se homogeneizaba con agua fisiológica estéril

- Para determinar la presencia de la bacteria las muestras se analizaban por serología DAS-ELISA

- Parte de la solución bacteriana se infiltraba en los espacios intracelulares de las hojas de tabaco para medir el nivel de fitopatogenicidad 
A

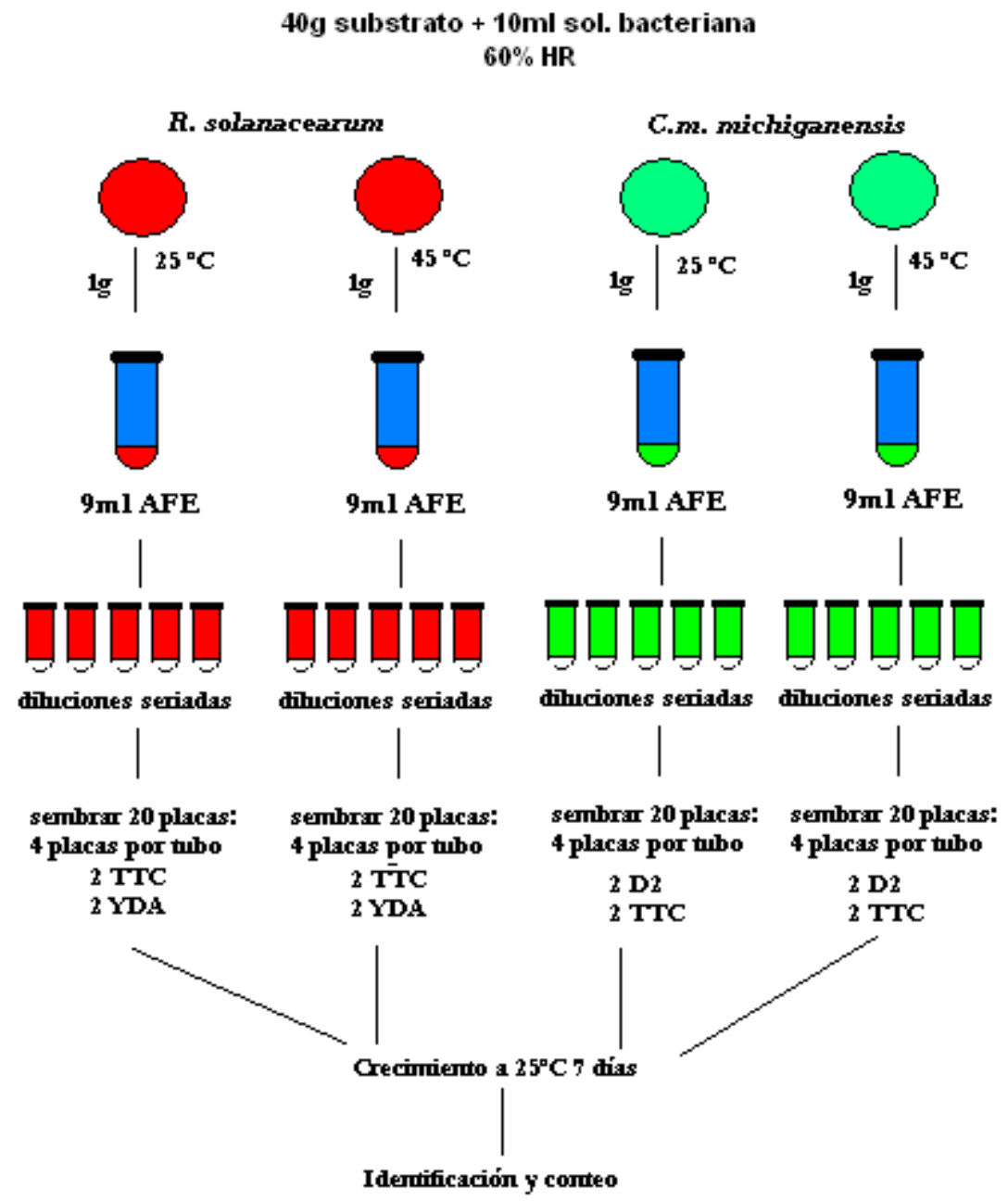

Figura 7.A: Esquema de la introducción y recuperación semanal de cepas bacterianas en substratos infectados artificialmente (AFE: agua fisiológica estéril). 


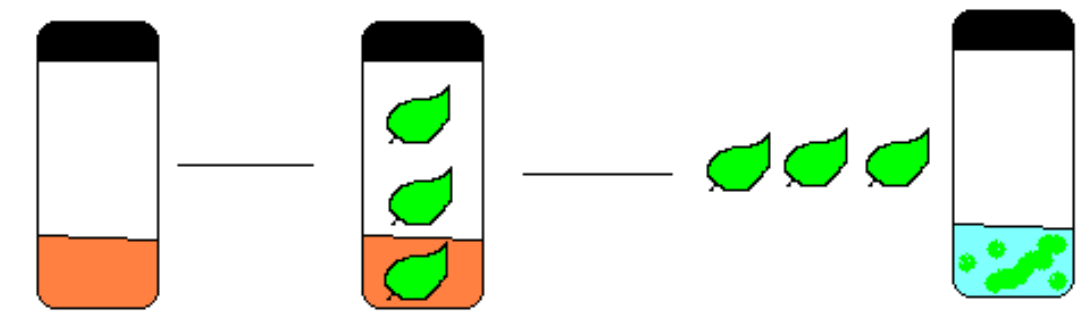

Semanalmente extracción,

tubos $6 \mathrm{~g}$ substrato Introducir 3 trozos de mat. veg. infectado lavado y machacado con agua estéril

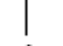

Análisis

Figura 7.B: Esquema de la supervivencia de los patógenos en asociación con tejidos vegetales

También se estudió la longevidad de las bacterias en asociación directa con los restos vegetales. Para ello un sólo trozo de tallo infectado se introducía directamente en tubos eppendorf estériles (de 1,5 $\mathrm{ml}$ de capacidad). De nuevo se preparaban 24 tubos por bacteria y la metodología era idéntica a la expuesta anteriormente para tubos de ensayo conteniendo material vegetal con substrato.

\subsection{Identificación de aislados bacterianos mediante PCR y secuenciación}

Diferentes cultivos puros obtenidos a partir de las colonias bacterianas aisladas en los apartados 1.6. y 1.7. se identificaron mediante secuencición parcial del gen $16 \mathrm{~S}$ rDNA.

Previamente a la amplificación de genes mediante la técnica PCR, se extraía el ADN de las muestras bacterianas (cultivos puros en placas Petri). Para la extracción del ADN se ensayaron las dos metodologías que se recogen a continuación: 
METODOLOGÍA I DE EXTRACCIÓN DE ADN BACTERIANO: usando el protocolo del "kit" comercial EaZy Nucleic Acid Isolation (E.Z.N.A. ${ }^{\circledR}$ OMEGA BIO-TEK, Inc. USA) siguiendo las instrucciones recomendadas por la casa comercial y que se indican en los siguientes pasos:

- en tubos Eppendorf de 1,5 $\mathrm{ml}$ de capacidad resuspender 1 pequeña cantidad de cultivo puro en $600 \mu 1$ de tampón P1 (proporcionado en el kit) y agitar con vortex

- incubar 5 min a $65{ }^{\circ} \mathrm{C}$ removiendo los tubos durante la incubación

- añadir $140 \mu 1$ de tampón P2 (proporcionado) y agitar con vortex

- centrifugar a $13000 \mathrm{rpm}$ durante $10 \mathrm{~min}$

- pasar $600 \mu \mathrm{l}$ del sobrenadante a otro tubo Eppendorf (sin añadir restos vegetales)

- añadir $600 \mu 1$ de etanol absoluto frío y $300 \mu 1$ de P3 (proporcionado) y agitar con vortex

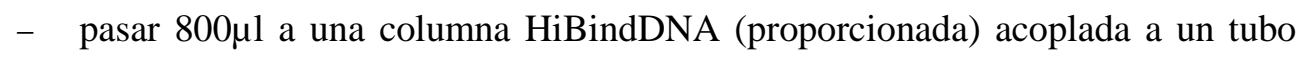
colector de $2 \mathrm{ml}$

- centrifugar a $13000 \mathrm{rpm}$ durante $1 \mathrm{~min}$

- descartar el filtrado conservando el tubo colector

- añadir el resto del extracto a la misma columna (aproximadamente unos 700 $\mu 1$ )

- centrifugar a $13000 \mathrm{rpm}$ durante $1 \mathrm{~min}$

- descartar el filtrado conservando el tubo colector. Poner la columna en un nuevo tubo colector

- añadir 750 $\mu$ l de wash buffer (proporcionado) verificando que se le ha añadido la cantidad indicada de alcohol

- centrifugar a $13000 \mathrm{rpm}$ durante $1 \mathrm{~min}$

- descartar el filtrado

- añadir otros $750 \mu \mathrm{l}$ de wash buffer, centrifugar a $13000 \mathrm{rpm}$ durante $1 \mathrm{~min}$ y descartar el filtrado 
- centrifugar de nuevo la columna con el tubo colector a $13000 \mathrm{rpm}$ para eliminar los restos de alcohol de la columna

- descartar el tubo colector e introducir la columna en un nuevo tubo Eppendorf estéril

- añadir $100 \mu \mathrm{l}$ de $\mathrm{H}_{2} \mathrm{O}$ PCR precalentada a $65^{\circ} \mathrm{C}$, esperar 1 min y centrifugar a $13000 \mathrm{rpm}$ durante $1 \mathrm{~min}$

- añadir otros $100 \mu 1$ de $\mathrm{H}_{2} \mathrm{O}_{\mathrm{PCR}}$ precalentada a $65^{\circ} \mathrm{C}$, esperar 1 min y centrifugar a $13000 \mathrm{rpm}$ durante $1 \mathrm{~min}$

- Etiquetar y congelar hasta procesar si no se utiliza de forma inmediata

\section{METODOLOGÍA II DE EXTRACCIÓN DE ADN BACTERIANO:}

- resuspender una pequeña cantidad de cultivo puro en $1 \mathrm{ml}$ de agua $\mathrm{H}_{2} \mathrm{O}$ PCR estéril

- agitar en vortex durante $2 \mathrm{~min}$

- hervir durante $10 \mathrm{~min}$

- centrifugar durante $10 \mathrm{~min}$ a $13000 \mathrm{rpm}$ y recoger el sobrenadante

- precipitar con 1/10 v de Ac Na (acetato sódico) 3M y con $2 \mathrm{v}$ de etanol absoluto

- dejar $2 \mathrm{~h} \mathrm{a}-20^{\circ} \mathrm{C}$

- centrifugar durante 10 min a $13000 \mathrm{rpm}$ y descartar el sobrenadante

- lavar con $500 \mu \mathrm{l}$ de etanol al 70\% y centrifugar durante 5 min a $13000 \mathrm{rpm}$

- secar durante $10 \mathrm{~min}$ al aire y el tubo boca abajo

- resuspender en $100 \mu \mathrm{l}$ de $\mathrm{H}_{2} \mathrm{O}_{\mathrm{PCR}}$ estéril

Los oligonucleótidos pA-pH (Edwards, 1989) se emplearon en la PCR y posterior secuenciación.

La amplificación se realizó en un volumen de $100 \mu$ l con $10 \mu 1$ de ADN, 100mM dNTPs, $10 \mu \mathrm{M}$ de cada cebador, $10 \mu \mathrm{l}$ de tampón de PCR 10x (100mM Tris-HCl pH 8,9, $1 \mathrm{M} \mathrm{KCl}, 15 \mathrm{mM} \mathrm{MgCl}_{2}, 500 \mu \mathrm{g} \mathrm{ml}^{-1}$ albúmina de suero bovino, $0,5 \%$ tween) y $5 \mathrm{u} \mathrm{ml}^{-1} \mathrm{de}$ Taq DNA polimerasa (Roche Molecular Biochemicals). 
Las condiciones de la PCR, respecto al perfil térmico, fueron las siguientes: 36 ciclos de desnaturalización a $94{ }^{\circ} \mathrm{C}$ durante 1 minuto, temperatura de anillamiento a $55{ }^{\circ} \mathrm{C}$ durante 2 minutos y una extensión a $72{ }^{\circ} \mathrm{C}$ durante 6 minutos. La PCR se realizó en un termociclador (Eppendorf Mastercycler Personal) y los productos obtenidos se analizaron mediante electroforesis horizontal en gel de agarosa al 1,2\% en tampón TBE y teñidos en un baño de bromuro de etidio $(0,5 \mu \mathrm{g}$ $\mathrm{ml}^{-1}$ ) durante 15 minutos y visualizados en un transiluminador de luz UV. Para estimar el tamaño de los fragmentos obtenidos se compararon con un marcador de ADN de 100pb (MBI Fermentas).

Los productos obtenidos fueron secuenciados previa purificación usando el kit comercial "High Pure PCR Product Purification Kit" (Roche). El protocolo recomendado se recoge a continuación:

- en un tubo Eppendorf se introducen 100 $\mu 1$ de producto PCR (llegando hasta 100 con $\mathrm{H}_{2} \mathrm{O}_{\mathrm{PCR}}$ estéril si es necesario)

- añadir $500 \mu \mathrm{l}$ de "binding buffer" (proporcionado)

- transferir los $600 \mu \mathrm{l}$ a un tubo colector (proporcionado) y centrifugar a 1300 rpm durante 30 seg descartando el líquido

- añadir 500 $\mu 1$ de "washing buffer" (proporcionado) y centrifugar a $1300 \mathrm{rpm}$ durante 1 min descartando el líquido

- añadir $200 \mu l$ de "washing buffer" de nuevo y centrifugar a 1300 rpm durante 1 $\min$

- descartar el líquido y el tubo colector e insertar el tubo con filtro en un Eppendorf de 1,5 ml de capacidad estéril

- Añadir 50 $\mu 1$ de $\mathrm{H}_{2} \mathrm{O}_{\mathrm{PCR}}$ estéril y centrifugar a $13000 \mathrm{rpm}$ durante $1 \mathrm{~min}$

- Repetir el paso anterior: Añadir $50 \mu 1{\text { de } \mathrm{H}_{2} \mathrm{O}}_{\text {PCR }}$ estéril y centrifugar a 13000 rpm durante $1 \mathrm{~min}$

- se obtienen $100 \mu 1$ de ADN purificado que se mantiene en nevera hasta mandar a secuenciar 
La secuenciación se llevó a cabo en el secuenciador automático ABI-337 (Perkin Elmer) del Instituto de Biología Molecular y Celular de Plantas (IBMCP) de la Universidad Politécnica de Valencia mediante el empleo del kit de secuenciación de DNA "Big Dye Terminator Cycle Sequencing (versión 2.0)” (PE Biosystem). Para establecer las secuencias nucleotídicas definitivas se empleó el programa CHROMAS (versión 1.45).

2. Biocontrol de Mycosphaerella brassicicola: efecto de diferentes tratamientos sobre restos de coles de Bruselas

\subsection{Experiencia en campo}

El experimento en campo se llevó a cabo en la localidad de Westmaas, localizada en el suroeste de Holanda, en la estación experimental de PPO-AGV. Para el ensayo, se recolectaron hojas de coles de Bruselas que presentaban síntomas de la mancha en anillo provocada por el hongo M. brassicicola. Estas hojas se recogieron durante Septiembre de 2007 y procedían de dos campos sometidos a distintas técnicas de manejo. Así, la mitad de las hojas procedían de un campo "orgánico" (de producción ecológica) localizado en Nagele, mientras que el resto de hojas procedían de un campo sometido a un manejo tradicional localizado en Lelystad. Ambas localidades se encuentran en el centro de Holanda (Figura 8). 


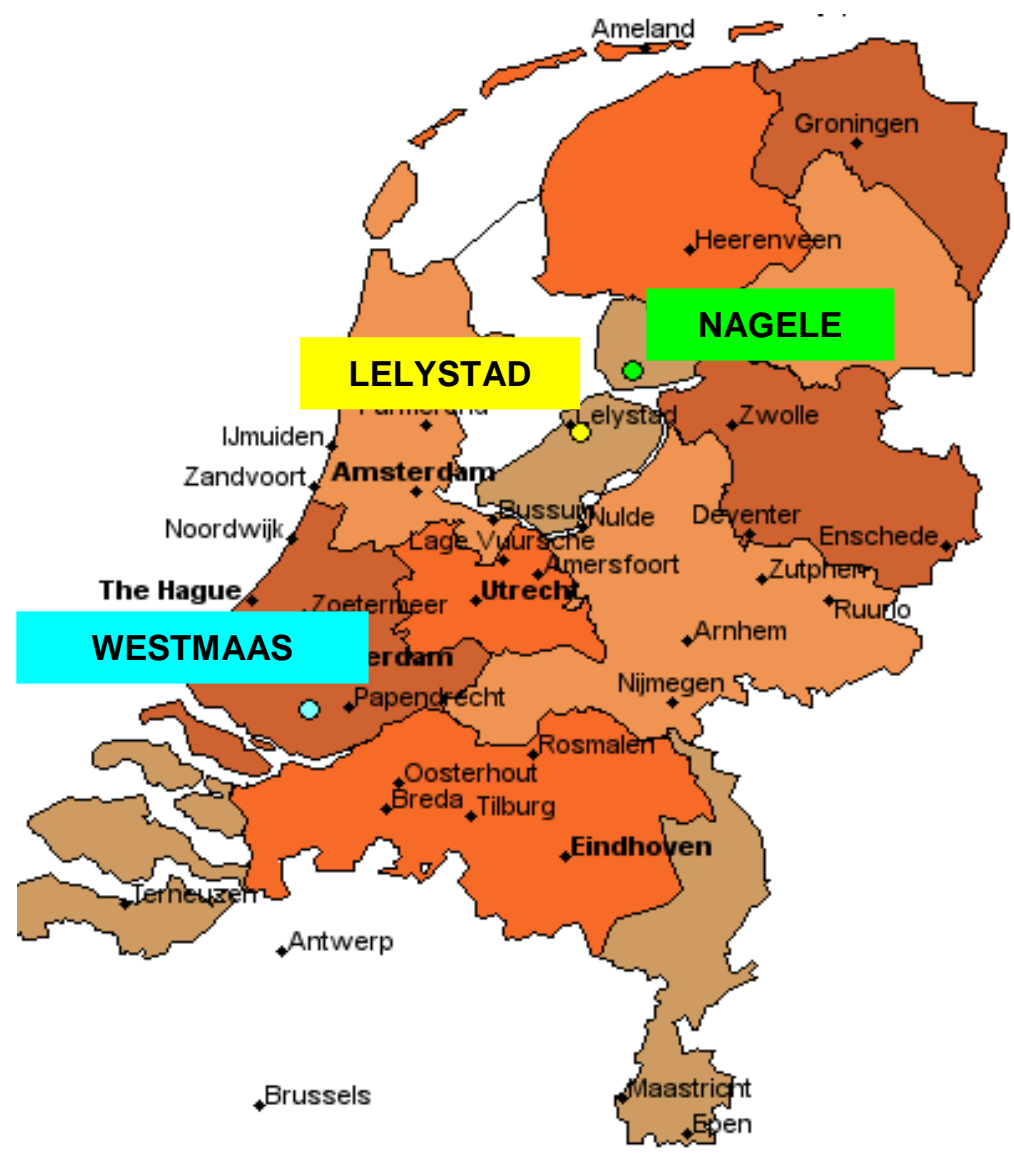

Figura 8. Mapa de Holanda (punto verde: Nagele; punto amarillo: Lelystad; punto azul: Westmaas)

Las hojas (unas 700 por cada localidad) se llevaron hasta la estación experimental en Westmaas y se prepararon para someterlas a la experiencia ensayada como se recoge a continuación.

Las hojas, en grupos de 4, se colocaron boca arriba en parrillas metálicas $(50 \times 50 \mathrm{~cm})$ que se cerraban empleando varillas metálicas. Se prepararon un total de 72 parrillas por localidad que se dividieron en 6 grupos de 12 parrillas. 
Para cada una de las localidades se preparaban 8 parrillas adicionales conteniendo "packs" de hojas consistentes en 7 hojas superpuestas de modo que se pudiera diferenciar los efectos de la descomposición en los diferentes niveles: arriba, en la zona central y en la inferior, que permanecía directamente en contacto con el suelo (Figura 9).

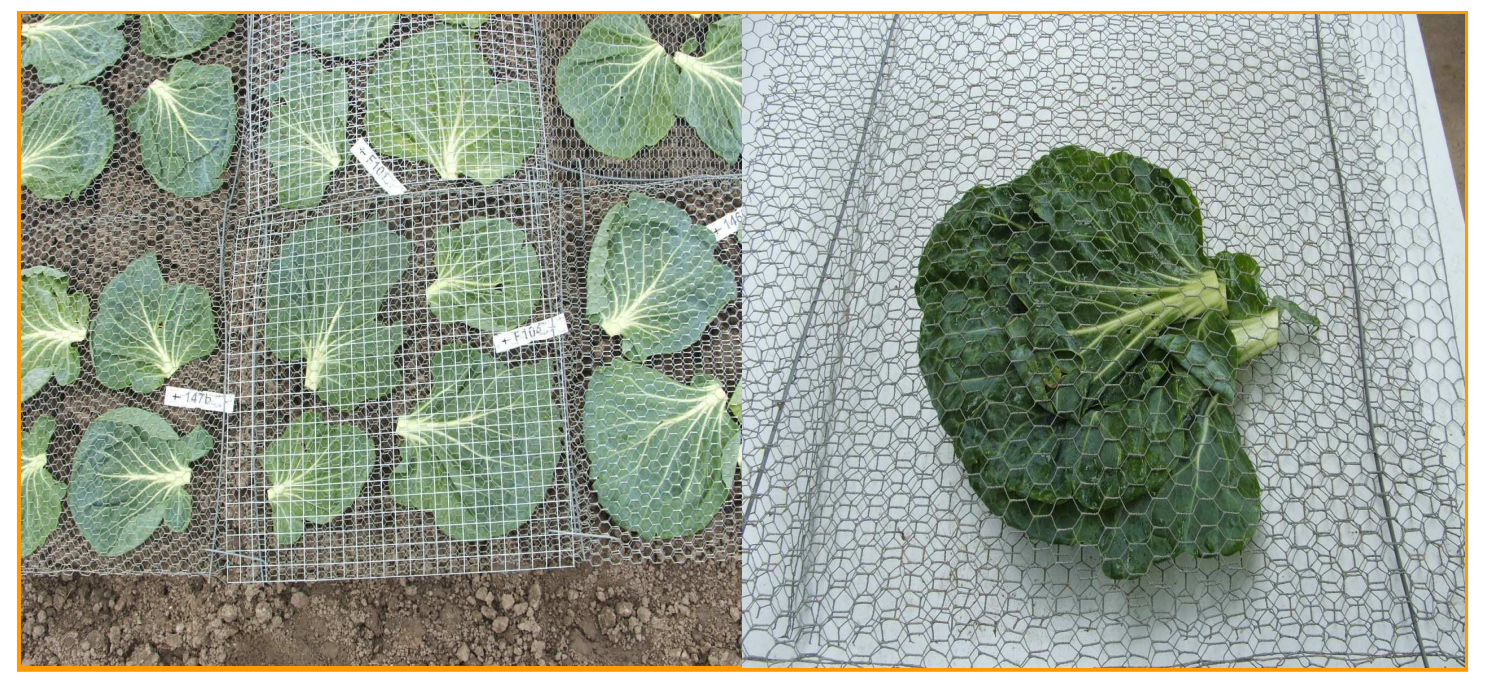

Figura 9. Parrillas preparadas con 4 hojas y "pack" de 7 hojas

Todas las parrillas se fijaron al suelo para someterlas al efecto de 7 tratamientos diferentes. En el campo, las parrillas se distribuyeron según se recoge en la figura 10: se prepararon 3 bloques correspondientes a las repeticiones para cada localidad y se ensayaron 7 tratamientos diferentes por bloque. Se planearon 4 épocas de muestreo retirando en cada uno dos parrillas por tratamiento y bloque, y 4 parrillas adicionales se empleaban para el estudio de descomposición.

La descomposición de las hojas, en función del tratamiento aplicado, se estudiaba mediante fotografías periódicas de las parrillas seleccionadas (siempre las mismas que se dejaban en el suelo), realizadas en los momentos de muestreo. 
La identificación mediante los correspondientes códigos de las muestras se recogen en el anejo 1.

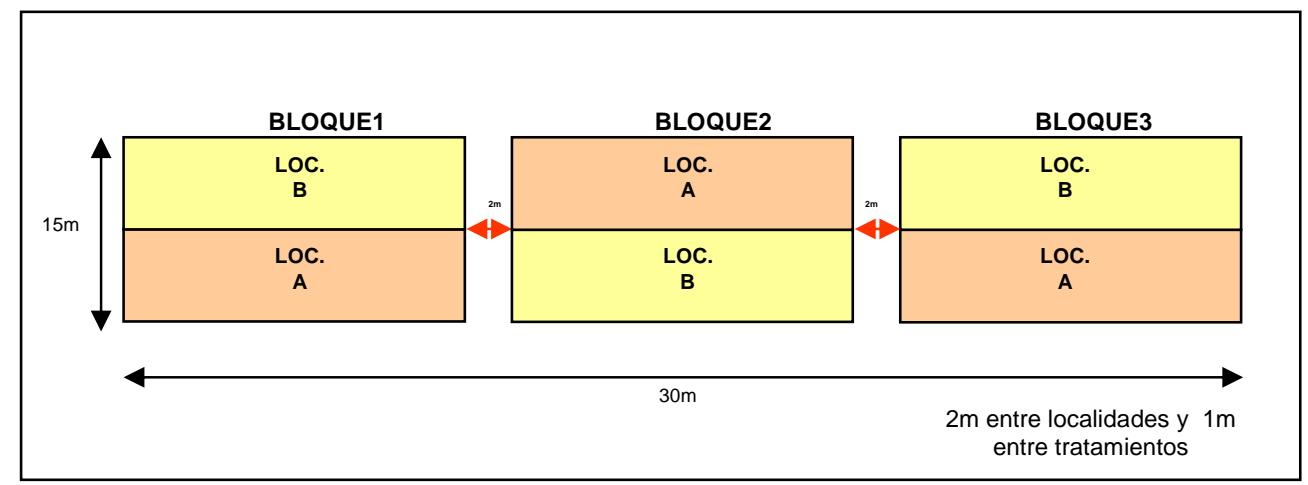




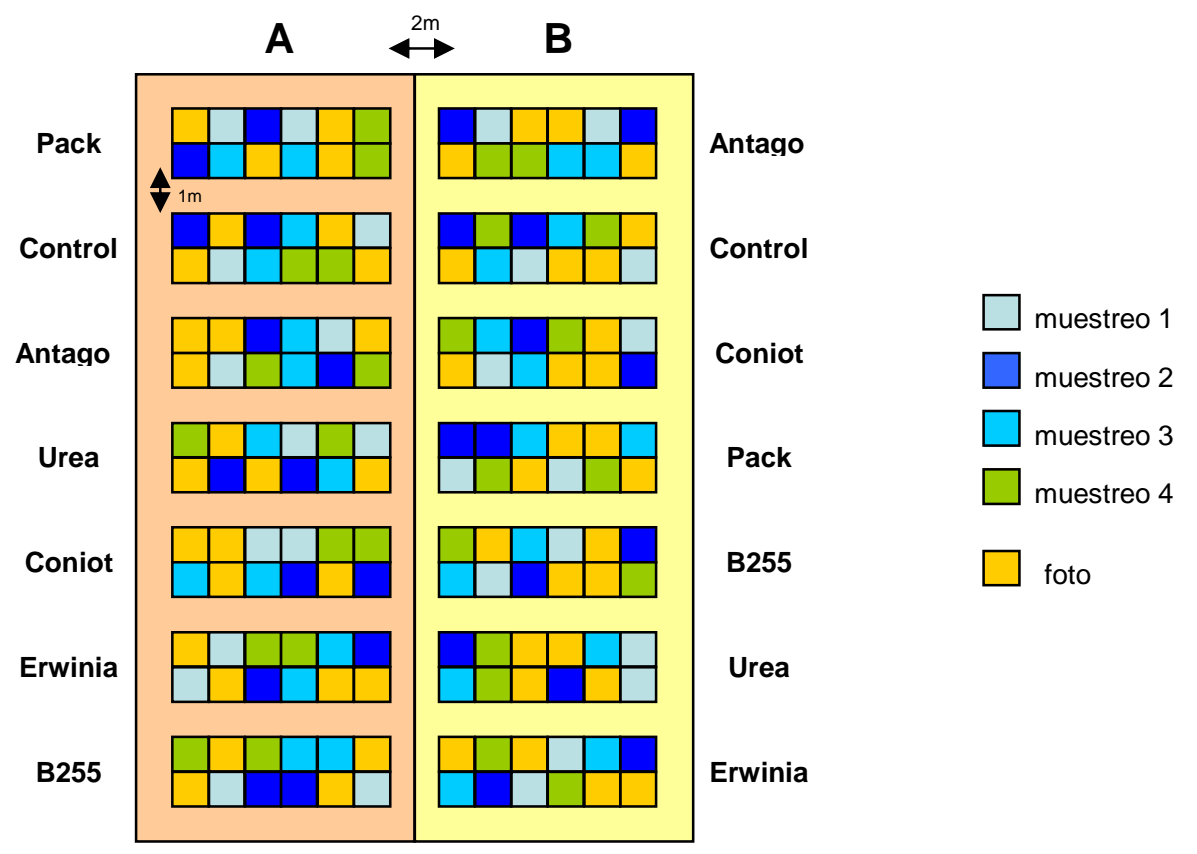

BLOQUE 1

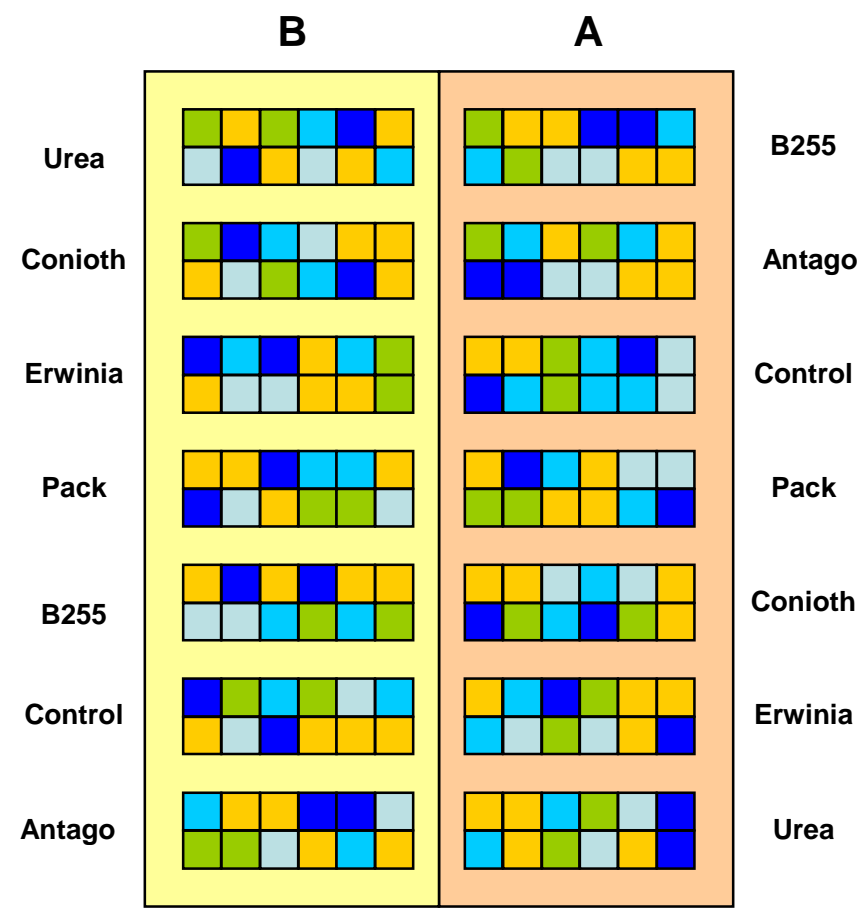

BLOQUE 2 


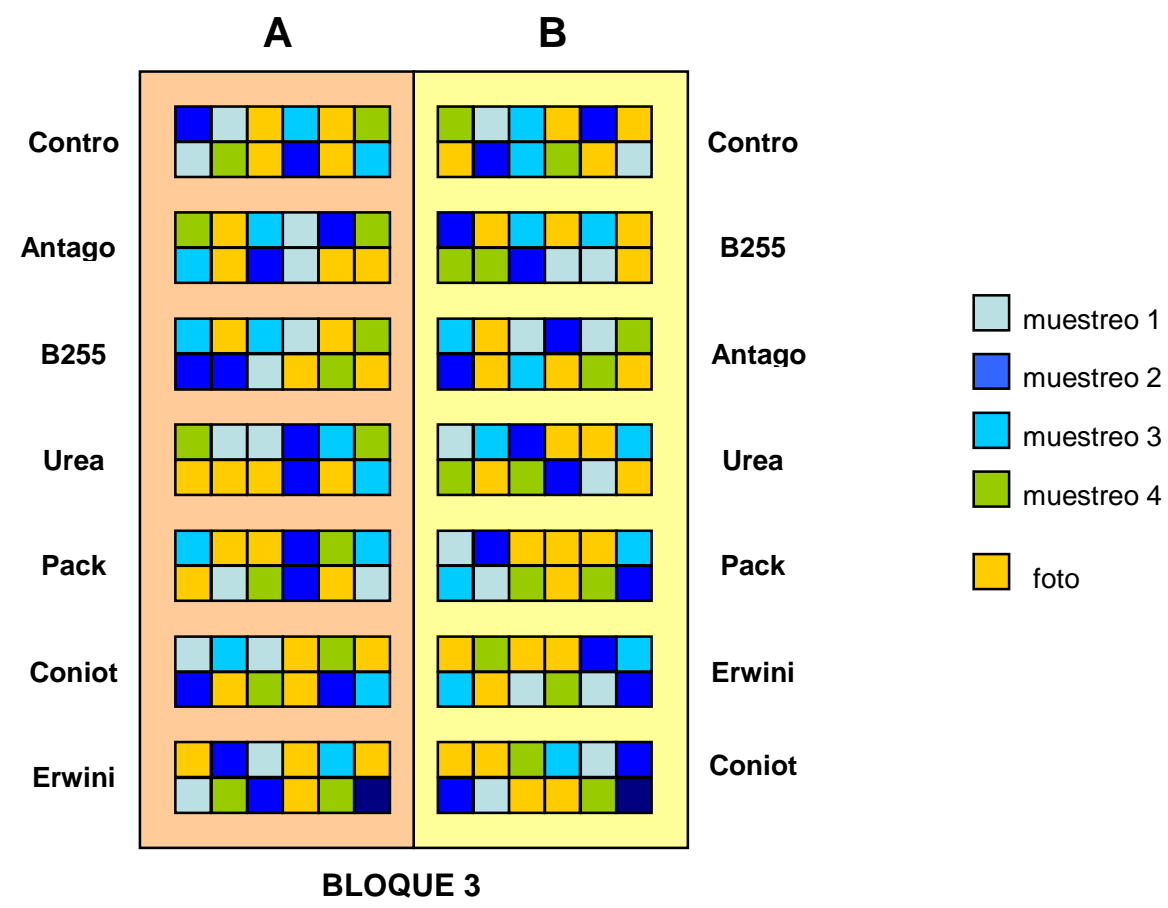

Figura 10. Esquema de tratamiento en campo: Localidad A: Nagele; Localidad B: Lelystad. Tratamientos: control con agua-Tween; Antago: hongo antagonista; B255: bacteria codificada; urea; packs tratados con agua-tween; Conioth: Coniothyrium pyrinum; Erwinia: Erwinia carotovora subsp. carotovora actual P. carotovorum. La evolución de la descomposición de las hojas se realizó mediante fotografías.

La posición de los tratamientos en cada uno de los bloques y las parrillas seleccionadas en cada época de muestreo, se determinó de forma aleatoria, al azar, usando el programa informático GenStat 7 (GenStat Committee, Algorithm Group Inc.). Todas las parrillas se colocaron en el suelo el 4 de Octubre de 2007 y al día siguiente se aplicaron los tratamientos. 


\subsection{Aplicación de tratamientos}

Para la aplicación de los diferentes tratamientos se prepararon diferentes suspensiones con las bacterias y hongos de biocontrol seleccionados.

El hongo $C$. pyrinum crecía en medio PDA (Potato Dextrose Agar; CM0139, Oxoid LTD., Hamphsire, Inglaterra) y las bacterias crecían en TSA 1/10 diluído (Trypticase Soy Agar 211043 BBL, Becton, Dickinson and Company, Francia). Las bacterias se dejaban crecer a $20^{\circ} \mathrm{C}$, durante 3 días y en oscuridad.

Las suspensiones se preparaban el mismo día de su aplicación al campo y se mantenían en fresco hasta el momento de la pulverización sobre las parrillas.

Para proporcionar una mejor cobertura de la superficie foliar las soluciones de placa se prepararon añadiendo agua-Tween, preparado añadiendo $1 \mathrm{ml}$ de Tween 50 al $10 \%$ por cada litro de agua $(0,01 \%)$; el tween permitiría una distribución más homogénea de las gotas sobre la superficie foliar.

Las concentraciones se ajustaron usando hemocitómetros; para las bacterias las concentraciones se ajustaban a $2 \times 10^{8} \mathrm{UFC} \mathrm{ml}^{-1}$ y para los hongos a 2 x $10^{6}$ esporas $\mathrm{ml}^{-1}$. La suspensión conteniendo urea se preparó añadiendo $50 \mathrm{~g}$ por cada litro de agua. Tanto los controles como los packs se trataron con agua-tween.

Los tratamientos se aplicaron dos veces, dejando 15 días entre la primera y la segunda aplicación. Para cada uno de los tratamientos se calculaba la cantidad de solución aplicada.

La forma de aplicación era mediante pulverización manual, de forma continuada durante 18 segundos, para cada tratamiento, excepto para los packs en los que el tiempo de pulverización era de 12 segundos. No sólo se intentaba homogeneizar la cantidad y tiempo, sino que todas las aplicaciones se realizaban a la misma presión (1,5 bar).

El primer muestreo (T1) se realizó justo un mes después de la aplicación de los tratamientos en campo (el 1 de Noviembre de 2007). 


\subsection{Muestreos y procesado de muestras}

Se planificaron 4 épocas de muestreo, pero en este trabajo sólo se recogen los resultados obtenidos en los dos primeros, realizados durante el periodo de duración de la estancia.

La recogida de muestras se realizaría mensualmente, de modo que en esta investigación se aportan los datos correspondientes al primer mes de ensayo en campo.

Cada uno de los momentos de muestreo que se detallan se denominaron T0 y T1:

- T0: justo al comienzo del ensayo con hojas que no se pusieron en parrillas y, por lo tanto, no se sometieron a ningún tratamiento. Se llevó a cabo con 12 muestras formadas por 6 grupos de 8 hojas, por cada localidad. Los resultados obtenidos de este primer muestreo resultarían interesantes al emplearlos con propósitos comparativos.

- T1: transcurrido un mes desde la distribución y tratamiento de las parrillas en campo. Para cada tratamiento se extraían las 8 hojas de dos parrillas, seleccionadas al azar. En total se retiraban 74 parrillas. Las 8 hojas se agrupaban y pulverizaban conformando una única muestra. En el caso de los packs, por cada dos parrillas se obtenían 3 muestras: la primera de ellas formada por las dos hojas de arriba, la segunda con las dos hojas del centro y la tercera estaba formada por las dos hojas inferiores de cada una de las parrillas. En total, para el muestreo T1, se obtuvieron 54 muestras.

Una vez que se prepararon las muestras, todas y cada una de ellas se procesaron para el conteo de ascosporas y para la cuantificación de ADN del hongo M. brassicicola. 


\subsection{Conteo de esporas}

Se siguió la metodología propuesta por Van den Ende (1998) empleando un método selectivo para la recolección de ascosporas basado en dispersión activa del hongo $M$. brassicicola. Este hongo libera rápidamente sus ascosporas en condiciones de elevadas humedades, lo que le proporciona cierta ventaja en su manejo frente a otros patógenos comunes en brassicas que no tienen esta dispersión activa de las esporas.

Este mecanismo de fácil dispersión puede ser empleado para la recolección selectiva de ascosporas procedentes de hojas enfermas de coles que se realizó como se recoge a continuación:

- 1 . En cada hoja se localizaban las lesiones de mancha en anillo y se contaban. Se seleccionó una de las lesiones por hoja y se medía $\left(\mathrm{cm}^{2}\right)$

- 2. Las lesiones (una por hoja) se extrajeron utilizando un sacabocados de $1 \mathrm{~cm}$ de diámetro

- 3. Las lesiones seleccionadas se mantenían en agua estéril durante 10-15 minutos

- 4. Para evitar contaminaciones por levaduras y otros microorganismos las lesiones se lavaban en etanol $70 \%$ durante 3 minutos y se enjuagaban en agua estéril. El tratamiento con alcohol no afecta a la esporulación de $M$. brassicicola.

- 5. Las lesiones se colocaban sobre papel de filtro humedecido, lo más centradas posible, en la tapa de placas Petri de plástico de $6 \mathrm{~cm}$ de diámetro

- 6. La parte de abajo de las placas Petri se rellenó con una fina capa (4ml) de agua-agar (15g de agar por litro de agua). Las placas se colocaban boca abajo, en bandejas con papel de filtro humedecido en el fondo e introducidas en bolsas de plástico transparentes para evitar la pérdida de humedad, en cámara a $15^{\circ} \mathrm{C}$ y ciclos de 16 horas de luz y 8 horas de oscuridad

- 7. Bajo condiciones óptimas de esporulación $\left(15^{\circ} \mathrm{C}\right.$ y $\left.90 \% \mathrm{HR}\right)$, las ascosporas salían disparadas recogiéndose en el agar-agua. 
- 8. El conteo de esporas se realizó bajo observación en microscopio (aumentos 10x). Se realizaban 8 conteos por cada una de las placas y se seleccionaba, para cada una de las lesiones, la misma superficie (empleando un ocular con gradilla: $0,63 \mathrm{~mm}^{2}$ )

\subsubsection{Análisis estadísticos}

De acuerdo con Van den Ende (1998), los análisis directos de los datos arrastrarían un incremento del error en el promedio, por lo que las medias del conteo de esporas para cada lesión se sometieron al análisis de la varianza tras la transformación logarítmica de $\operatorname{los}$ datos $\left(\log _{10}(\mathrm{x}+1)\right)$, donde $\mathrm{x}$ es el número de esporas por $\mathrm{mm}^{2}$. Los datos se analizaron mediante el paquete estadístico Statgraphics (Statgraphics Plus software 4.1., Manugistics Inc., Rockville, MD,USA). Las diferencias entre tratamientos se analizaron comparando medias mediante el test LSD (del ingles "Least Significance Difference") de Fisher con un nivel de probabilidad del $95 \%$.

\subsection{Cuantificación de ADN: PCR en tiempo real}

Tras la extracción de lesiones para el conteo de esporas, las 8 hojas de la misma muestra se volvieron a agrupar, se pesaban y, a continuación, se procesaban para la extracción de ADN.

Los grupos de hojas ( 8 por tratamiento y 2 para los packs) se colocaban en bolsas de plástico y se almacenaban a $-18^{\circ} \mathrm{C}$ hasta su procesado posterior.

\subsubsection{Procesado de muestras}

Las muestras se troceaban empleando tijeras desinfectadas con alcohol en cada cambio de muestra e, inmediatamente, se llenaban dos viales de plástico que se almacenaban de nuevo a $-18^{\circ} \mathrm{C}$.

El resto de muestra troceada se pesaba para la obtención de su peso seco siguiendo 4 pasos: 
- Las muestras se mantenían 5 horas a $70^{\circ} \mathrm{C}$

- 7 horas a $105^{\circ} \mathrm{C}$

- Tras 12 horas las muestras se almacenaban a $50{ }^{\circ} \mathrm{C}$ evitando una rápida rehumificación

- Las muestras se pesaban y se calculaba el peso seco

Las muestras recogidas en los dos viales de plástico, reservados a $-18{ }^{\circ} \mathrm{C}$, fueron secadas en frío y seguidamente pulverizadas en un molinillo de laboratorio (con cribado en malla de $1 \mathrm{~mm}$ ). El molinillo se limpiaba empleando aire presurizado y con etanol (70\%) en cada cambio de muestra, implicando una limpieza exhaustiva del material empleado, lo que alargaba todo el proceso de pulverizado.

Las muestras, ya pulverizadas, se almacenaban a $-18{ }^{\circ} \mathrm{C}$, en los viales de plástico, hasta la posterior extracción de ADN.

\subsubsection{Extracción de ADN}

La extracción de ADN se realizaba partiendo de 10 a $13 \mathrm{mg}$ de las muestras pulverizadas mantenidas en los viales de plástico empleando el kit comercial Dneasy 96 plant kit para la purificación de ADN procedente de tejidos vegetales congelados (Qiagen, Westburg, Alemania) de acuerdo con el protocolo aportado por el fabricante y que permitía la extracción simultánea del ADN de 96 muestras.

\subsubsection{PCR en tiempo real}

Para la cuantificación de ADN de M. brassicicola en cada muestra se empleaba la técnica de PCR en tiempo real.

Los primers y las sondas para la detección de M. brassicicola así como para la aplicación del control interno (Green Fluorescent Protein, GFP) se empleaban siguiendo los protocolos cedidos por el Plant Research International de 
Wageningen (de Haas y Köhl, sin publicar y, por lo tanto, no pudiendo ser facilitados en este trabajo).

Para la PCR en tiempo real las reacciones TaqMan se llevaban a cabo en el formato de 96-pocillos en un aparato 7500 Real Time PCR System de Applied Biosystems.

Para cada placa de 96 pocillos se preparaban diluciones seriadas que iban desde $30000 \mathrm{fg}$ hasta $30 \mathrm{fg}$ para el patógeno correspondiente, M. brassicicola, obtenidas a partir de cultivos puros y que se corrían en paralelo como cantidades de referencia.

\subsubsection{Análisis estadísticos}

Las cantidades de ADN (fg ADN por gramo de peso seco) obtenidas a partir de la PCR en tiempo real se sometieron a análisis de varianza tras una transformación logarítmica de los datos, esta vez ya no en base 10, sino la transformación logarítmica-normal o neperiana $(\operatorname{Ln}(x+1))$ que ajusta los datos a una distribución normal, donde x son los fg de ADN.

Los datos se analizaron mediante el paquete estadístico Statgraphics (Statgraphics Plus software 4.1., Manugistics Inc., Rockville, MD,USA). Las diferencias entre tratamientos se analizaron comparando medias mediante el test LSD (del ingles "Least Significance Difference") de Fisher con un nivel de probabilidad del $95 \%$. 



\section{RESULTADOS Y DISCUSIÓN}

\section{Clavibacter michiganensis subs. michiganensis}

\subsection{Crecimiento en placa y test de patogenicidad en tabaco}

Como ya se ha comentado, previamente a la aplicación de las técnicas de control de las bacterias seleccionadas, se estudiaron detenidamente la morfología y comportamiento de dichas bacterias en los medios y condiciones disponibles con el objetivo de garantizar un manejo adecuado.

Para el caso de C.m.michiganensis, las colonias bacterianas crecieron en medio selectivo D2 de Kado y Heskett (1970) mostrando una coloración amarilla (fácilmente distinguibles) y lo hacían tras permanecer $48 \mathrm{~h}$ en estufa a una temperatura de $28{ }^{\circ} \mathrm{C}$, con calor seco. No se observaron diferencias de comportamiento importantes en relación con el crecimiento bacteriano entre los distintos medios de cultivo empleados: general (YDA) o selectivo (D2), por lo que, para evitar problemas de contaminación y facilitar futuras identificaciones se decidió mantener los cultivos puros iniciales (denominados placas madre) y posteriores repicados en medio D2.

En la figura 11 se observan colonias de la cepa empleada de C.m.michiganensis crecidas en D2.

Respecto al resultado de la inoculación en los espacios internerviales de plantas de tabaco, el avance de la enfermedad se ve afectado por las condiciones ambientales del lugar donde se realiza la inoculación, en este caso, en condiciones normales de invernadero. De acuerdo con dichas condiciones, la respuesta hipersensible del huésped tardaba entre 3 y 4 días en avanzar hasta observar necrosis en las zonas de infiltración. El avance de la respuesta se observa en la figura 12. 


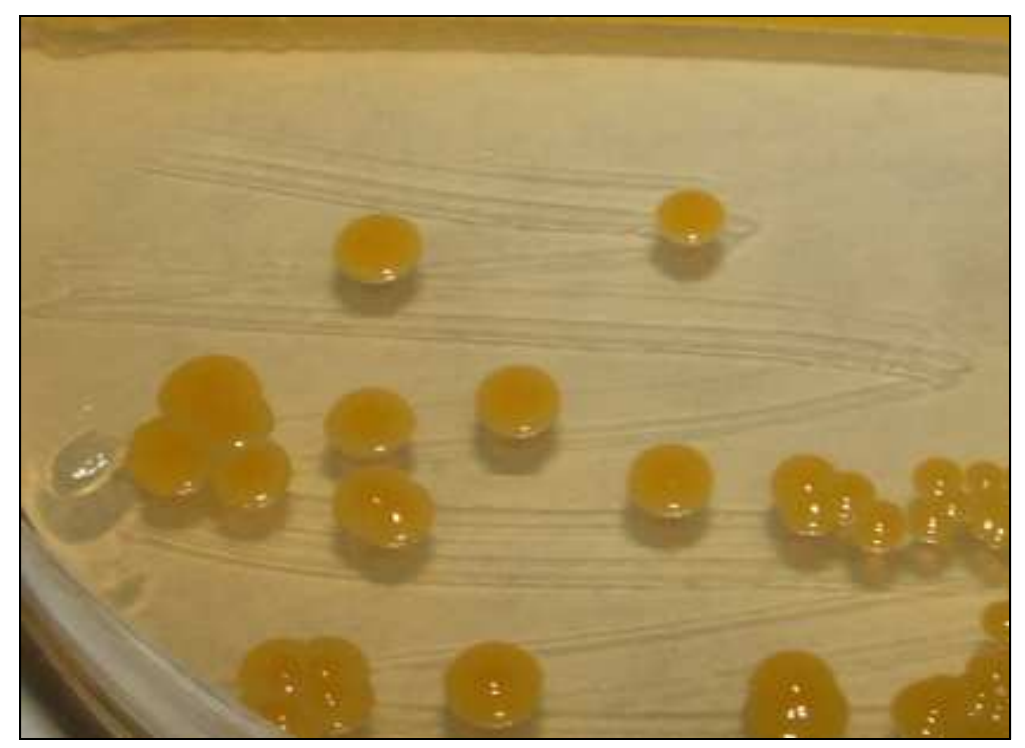

Figura 11. Aspecto de las colonias de C.m.michiganensis en D2.

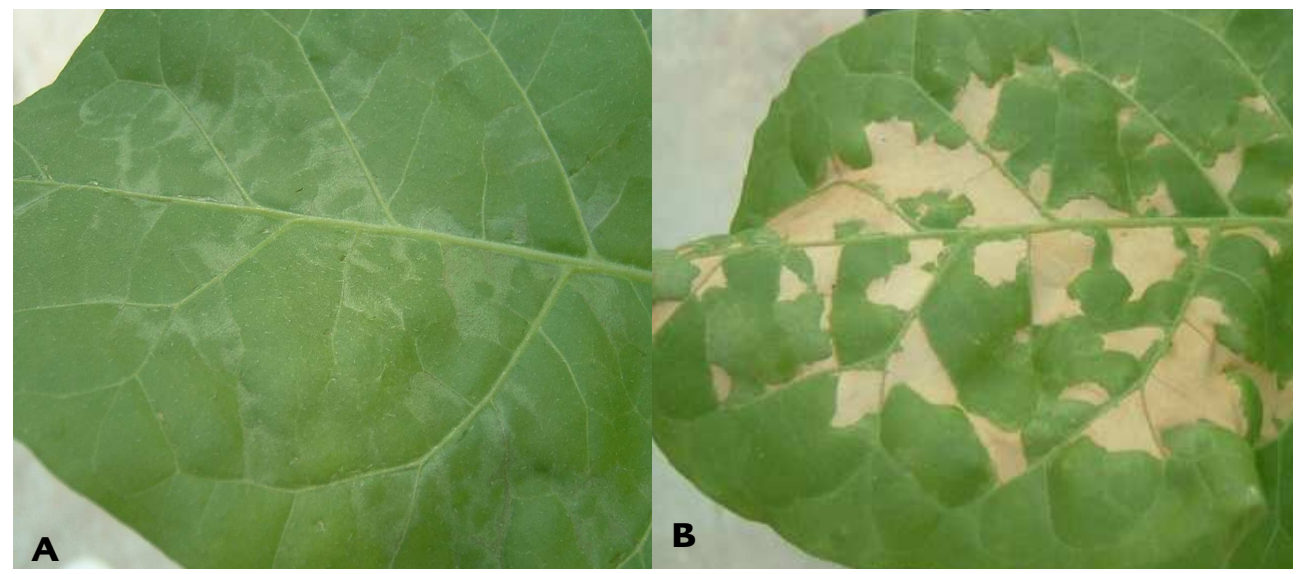

Figura 12. Avance de la respuesta hipersensible de C.m.michiganensis en plantas de tabaco, en las condiciones de ensayo en invernadero. A: avance de síntomas transcurrido 1 día desde la inoculación. B: estado de la zona infiltrada transcurridos 4 días desde la inoculación 
La técnica expuesta de inoculación en hojas de tabaco para la determinación de la respuesta hipersensible $(\mathrm{RH})$ es una de las técnicas que se aplican habitualmente en el manejo de bacterias. Así, de acuerdo con Klement et al. (1964), tras la inoculación de plantas de tabaco con distintas cepas bacterianas, se producía la muerte rápida de la zona inyectada con la solución ensayada.

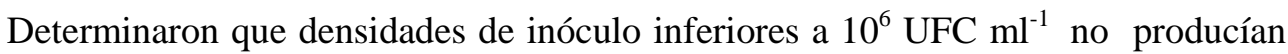
estos mismos síntomas sino que se observaban lesiones de muy pequeño tamaño, sólo distinguibles bajo ampliaciones microscópicas de 10 a 12 aumentos proporcionales en número al de bacterias inyectadas. Además estas pequeñas lesiones no crecían con el paso del tiempo. Debido a este resultado, en el presente trabajo, se decidió inocular las plantas de tabaco con concentraciones bacterianas no inferiores a $10^{8} \mathrm{UFC} \mathrm{ml}^{-1}$.

Gitaitis, en 1990, ya indicaba la infiltración de los espacios intercelulares de las hojas de las plantas, con suspensiones acuosas de bacterias, como uno de los métodos más eficaces en la determinación de una $\mathrm{RH}$ en relación con la fitopatogenicidad de las colonias, incluso indicaba que se trata de una técnica útil en la identificación de determinadas bacterias fitopatógenas. Además, recuerda en su trabajo que algunos autores dividen la $\mathrm{RH}$ en varios tipos diferentes que incluyen el tipo I (la temperatura no afecta a la $\mathrm{RH}$ ), el tipo II (las altas temperaturas mejoran la $\mathrm{RH}$ ) y el tipo III (las bajas temperaturas mejoran la $\mathrm{RH}$ ). Las plantas de tabaco, en el caso de ser inoculadas con C.m.michiganensis, se incluyen dentro del tipo III, de modo que los síntomas de necrosis se observan sólo temperaturas cercanas a $25^{\circ} \mathrm{C}$ pero no a $38^{\circ} \mathrm{C}$. De aquí la importancia de controlar las temperaturas en condiciones de invernadero si se decide trabajar con plantas de tabaco, como en el presente trabajo.

\subsection{Inoculación artificial en plantas de tomate: sintomatología asociada}

La inoculación artificial de las soluciones bacterianas con la cepa en estudio de C.m.michiganensis en las axilas de hojas de tomate provocaba síntomas 
severos que se observaban transcurridos de 12 a 14 días desde la inoculación. Distintos autores (Strider, 1970; Chang et al., 1991), estudiaron los síntomas asociados a distintos métodos de inoculación, e indicaron que las heridas se convierten en los puntos lógicos de entrada para la infección sistémica de C.m.michiganensis, razón por la que se seleccionó este tipo de inoculación.

Los síntomas consistían en un marchitamiento progresivo que afectaba primeramente a las hojas en cuya axila se había introducido la solución bacteriana. Se producía su amarilleo, llegando a afectar al limbo de los foliolos, seguido de una flaccidez y al presionarlo emanaban exudados bacterianos.

Conforme la enfermedad avanzaba en el tallo aparecían chancros, similares a heridas abiertas (figura 13). En la zona interna, los vasos conductores aparecían necrosados. Estos síntomas se muestran en la figura ---.

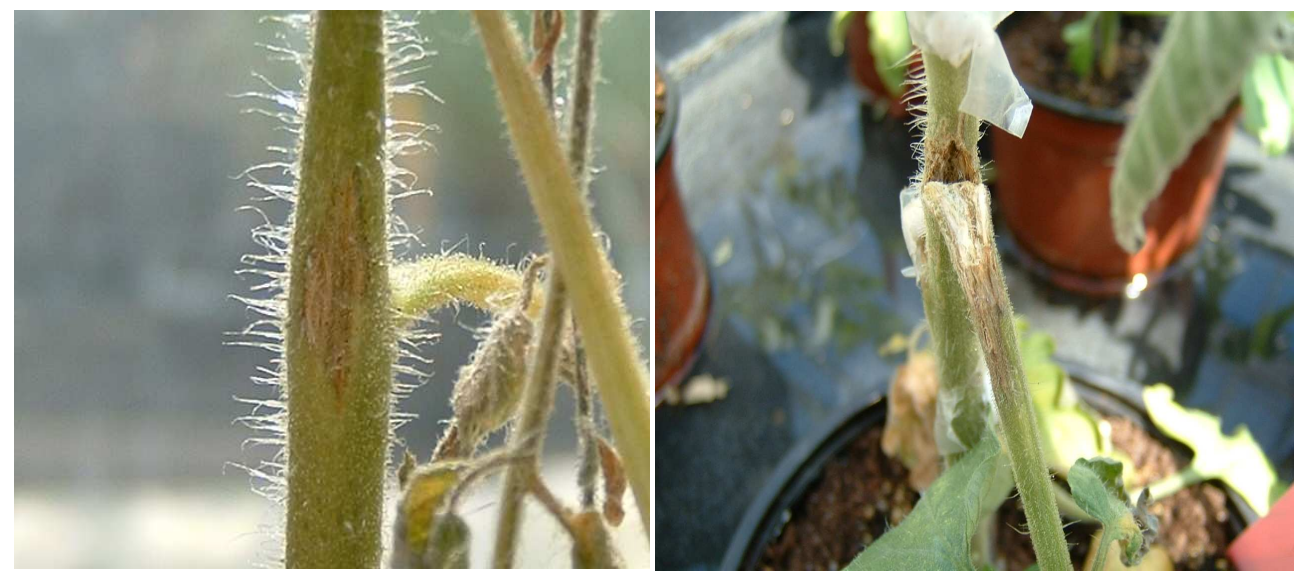

Figura 13. Plantas de tomate con síntomas de chancros observados tras la inoculación de C.m.michiganensis

Los resultados en cuanto al periodo de tiempo que transcurre desde la inoculación hasta que se observan los primeros síntomas concuerdan con los publicados por Gitaitis y Leben (1988) y Gitaitis et al. (1991). En los trabajos que exponen, aunque la inoculación se realiza de forma diferente, puesto que emplean 
herramientas infectadas cortando las plantas que quieren inocular, los síntomas de la enfermedad bacteriana tampoco se hacen evidentes hasta que han transcurrido 17 días. Por esta razón se corrobora que la enfermedad asociada a la presencia de C.m.michiganenesis en plantas de tomate tras su inoculación artificial, independientemente de la técnica empleada, muestra sus síntomas entre 12 y 17 días tras su introducción en las plantas huéspedes.

Respecto a como se produce el avance de la infección, se pueden diferenciar claramente las tres etapas indicadas por Jahr et al. (1999) ya que la infección de huéspedes se produce mediante la introducción de las bacterias a través de heridas o a través de tricomas (Huang, 1986), seguida por la invasión de los vasos xilemáticos y causando una enfermedad vascular sistémica, que incluso implica la aparición de chancros. Estos últimos autores recogen, mediante microscopía electrónica de barrido, como actúan las bacterias en el interior de los tejidos respondiendo el por qué C.michiganensis induce el marchitamiento de las plantas afectadas.

A continuación se recogen los resultados de la evaluación microscópica de plantas con síntomas.

\subsection{Microscopía electrónica de barrido de tallos de tomate inoculados artificialmente}

Las interacciones ultraestructurales entre la bacteria C.m.michiganensis y los tejidos vegetales afectados por su inoculación se muestran en la figura 14 . 

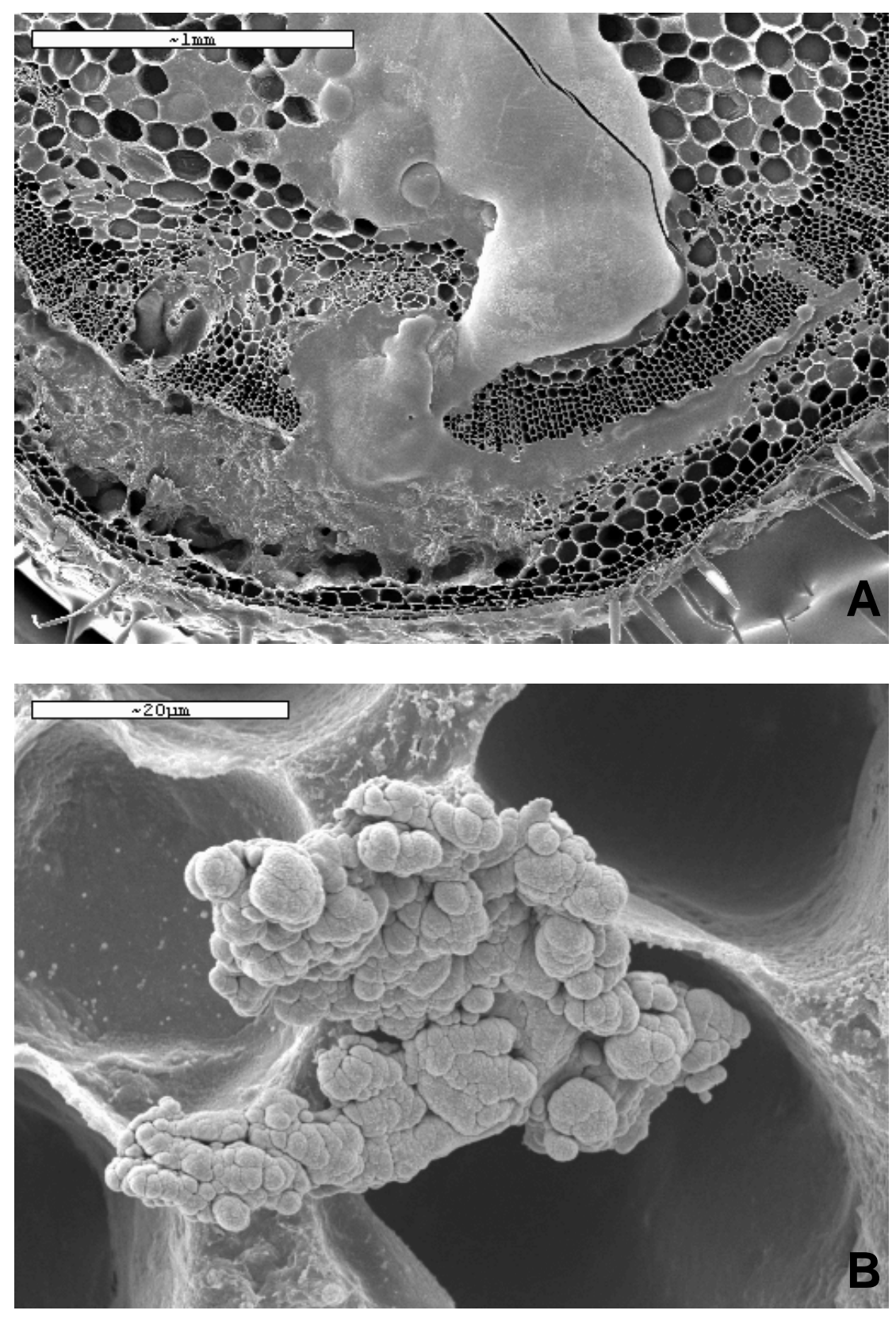

Figura 14. Imágenes observadas por microscopía electrónica de barrido de una sección transversal de un tallo infectado de tomate (Lycopersicon esculentum) colapsado por masas bacterianas. A: Masas bacterianas emanando desde los vasos conductores obstruidos B: Bacterias bloqueando los vasos xilemáticos 
Como se deduce de los resultados obtenidos, las secciones transversales de tallos inoculados muestran que muchos de los vasos del sistema vascular están colapsados y contienen masas bacterianas (Leyns y De Cleene, 1983; Gleason et al., 1991), síntoma que implicará problemas en el transporte de agua contribuyendo al marchitamiento progresivo de la planta (Jahr et al., 1999).

Como adición a lo anterior, no hay que olvidar la actuación de los exopolisacaridos (EPS) producidos por la bacteria en estudio, compuestos por fucosa, galactosa y glucosa $(2: 1: 1)$ con acetato y piruvato. Los EPS tienen un carácter ácido que les confiere actividad en el intercambio de iones, influenciando también en el aporte de minerales y nutrientes. Además, varias cepas de C.michiganensis producen celulasas y pectinasas, enzimas extracelulares que pueden atacar y degradar las paredes celulares. Diversos estudios morfológicos sugieren que los enzimas extracelulares también contribuyen al marchitamiento al atacar a los vasos xilemáticos y a las células parenquimáticas adyacentes (Jahr et al., 1999).

Se confirma, como resultado, que las plantas infectadas se marchitan lentamente y pueden observarse estrías marrones tanto en tallos como en peciolos, que si se rajan se transforman en chancros. Del mismo modo se ha comprobado que los síntomas en las plantas de tomate inoculadas artificialmente con C.m.michiganensis, pueden observarse transcurridos 15 días tras la inoculación en plantas con cuatro semanas de edad, todo ello coincidiendo con la información aportada por la OEPP/EPPO (2005).

Una vez determinados el comportamiento y sintomatología que provoca la cepa bacteriana que se va a inocular en las plantas huéspedes seleccionadas comprobándose su patogenicidad, se puede comenzar con el bioensayo en macetas para determinar el efecto de la biofumigación y biosolarización en el control de C.m.michiganensis, en las condiciones de ensayo. Se empleó la técnica PCR con posterior secuenciación de la cepa empleada (GenBank Accession No. EU857429) para su previa identificación como C.m.michiganensis al inicio del bioensayo. 


\subsection{Diseño de la experiencia de biofumigación y biosolarización en condiciones de invernadero}

\subsubsection{Tratamiento de biofumigación en macetas: $25^{\circ} \mathrm{C}$}

Siguiendo la metodología expuesta en el apartado 1.5.1. el ensayo de biofumigación se realizó bajo condiciones de invernadero. Cabe recordar que se consideró biofumigación cuando la temperatura ensayada fue la de $25{ }^{\circ} \mathrm{C}$ y todos los resultados se van a comparar con los obtenidos a $45^{\circ} \mathrm{C}$.

En los lotes, la mitad de las macetas preparadas incorporando material vegetal sano se consideraron como controles, al igual que 8 macetas por lote conteniendo únicamente substrato, controlando posibles contaminaciones y observando aspectos sintomatológicos, especialmente el efecto en crecimiento y desarrollo de vigor dependiendo de las condiciones de invernadero y sus modificaciones.

En este caso, sí que se observaron diferencias de desarrollo en el lote 0, es decir, sin ningún tipo de tratamiento, entre aquellas plantas que crecieron sobre substrato conteniendo material vegetal infectado que las que lo hacían sobre substrato conteniendo restos de tomate sanos (figura 15). Pero los efectos sólo se observaron en este lote que servía como indicador del nivel de la afección bacteriana previa al desarrollo del ensayo. Conforme avanzaban las semanas de tratamiento, incluso a $25^{\circ} \mathrm{C}$, y a partir de la primera, estas diferencias desaparecían. 


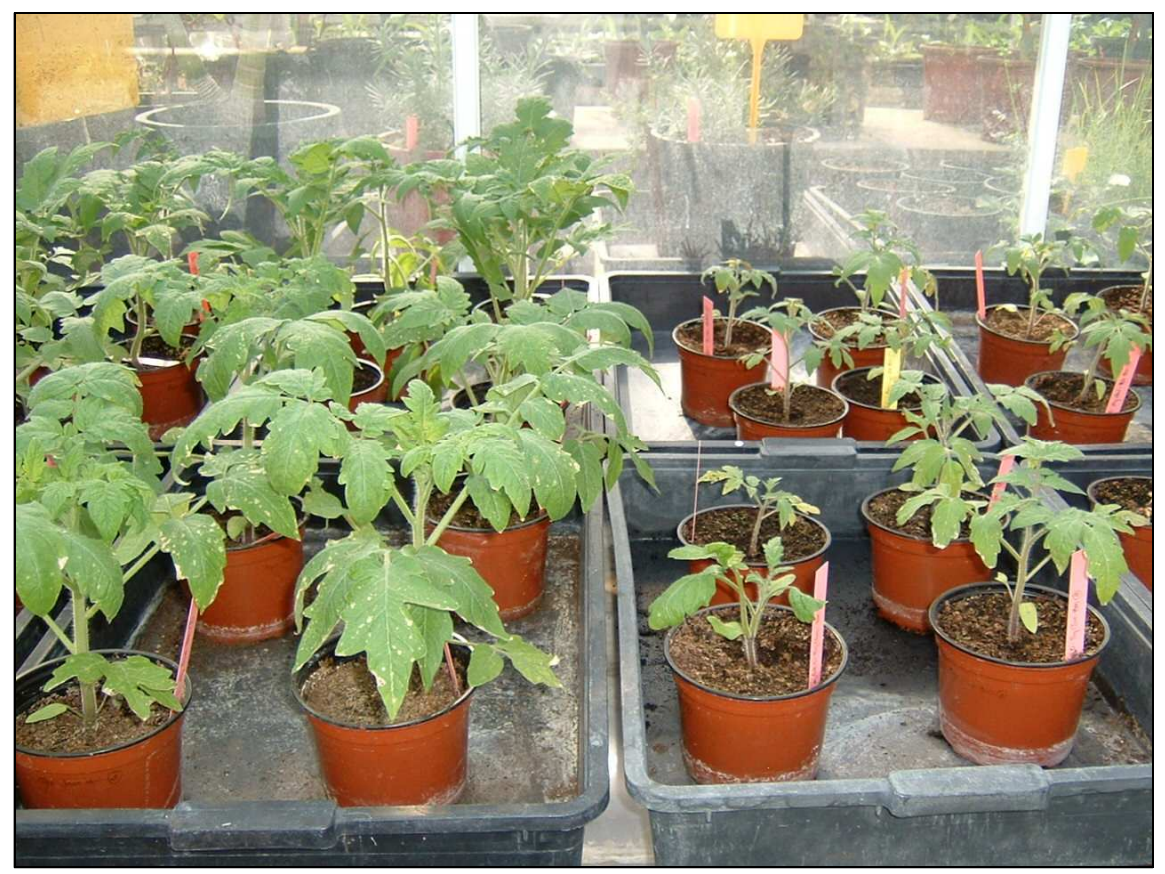

Figura 15. Diferencia de crecimiento observada entre plantas del lote 0 (sin ningún tipo de tratamiento térmico) crecidas sobre substrato conteniendo restos de tomate sanos (a la izquierda) y plantas sobre substrato con restos de tomate infectados (a la derecha).

La disminución de crecimiento se asocia a la presencia del patógeno en el substrato alcanzando niveles en los que se convierten en factores limitantes para el crecimiento de las plantas (Stapleton y DeVay, 1984) debido a la posible producción de sustancias asociadas a la bacteria en estudio (Van der Bulk et al., 1991).

Si se realiza una observación de las raíces de las plantas crecidas sobre substratos infectados, el crecimiento se ve reducido en función de la dosis $(5,10$ y $15 \mathrm{~g}$ ) de material vegetal inoculado artificialmente que se había enterrado en las macetas: a mayor dosis, menor crecimiento y mayores son los daños ocasionados a nivel radicular (figura 16). 


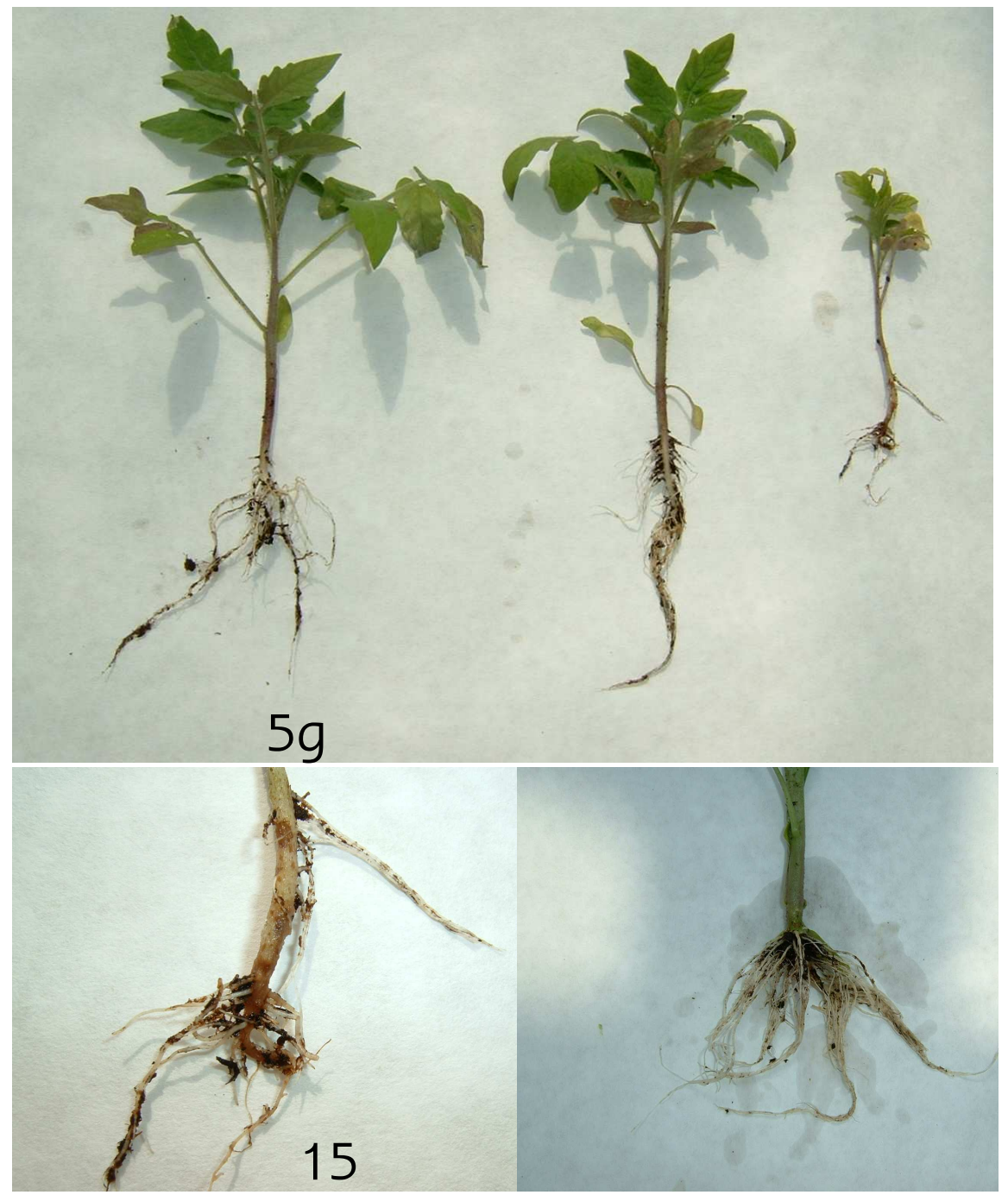

Sana

Figura 16. Comparación de raíces de plantas de tomate crecidas sobre substratos conteniendo distintas dosis de restos de tomate infectados con C.m.michiganensis y detalle de daños ocasionados en raíces de plantas crecidas sobre substratos con $15 \mathrm{~g}$ de material infectado en comparación con raíces de plantas de tomate totalmente sanas. 
Considerando que en las condiciones de ensayo las bacterias penetran en el interior de las plantas a través del sistema radicular al entrar en contacto con el substrato infectado, se observaron daños que avanzaban desde las partes inferiores hasta alcanzar los vasos conductores, llegando a la parte aérea y marchitando la planta e incluso apareciendo chancros en tallos. En función de estos resultados, se cifraron en 40 los días que debían transcurrir desde el transplante para asegurar la detección de la bacteria por la técnica serológica aplicada. Los daños observados en la figura 2 confirmarían los estudios realizados por Gómez et al. (2006) acerca de la alta capacidad infectiva de la bacteria por vía radicular y sirven para asegurar un modo de acceso garantizado en caso de presencia bacteriana en el substrato, en las condiciones de ensayo.

Para la obtención del material infectado con C.m.michiganensis el tiempo estipulado para asegurar la presencia de la bacteria en las plantas de tomate, artificialmente inoculadas por infiltración en las axilas de las hojas, era de 12 a 17 días (Gitaitis, 1991), reduciéndose en aproximadamente 20 días respecto a la entrada del patógeno vía radicular.

Se compararon las diferencias observadas en raíces (tanto en desarrollo como en detección de síntomas de necrosis) de plantas infectadas a través de la penetración bacteriana por vía radicular por contacto directo con el substrato infectado con las raíces de plantas que fueron inoculadas a través de infiltraciones en las axilas de las hojas (que provoca una rápida infección sistémica), comparándose con el aspecto del sistema radicular de una planta sana (figura 17).

Observando la figura 17, no sólo aparecen daños en la zona radicular, con mayor afección en el caso de contacto directo con el substrato infectado donde las zonas necrosadas son más abundantes, sino que también se observan daños en la zona del cuello de las plantas infectadas. Todo ello, implicará un menor crecimiento y menor vigor de las plantas dañadas, avanzando hasta un estado de marchitamiento a causa de la mala absorción de agua y nutrientes, efectos también 
indicados por Jahr et al. (1999). Síntomas a considerar en el caso de que los lotes no fuesen sometidos a ningún tipo de tratamiento.

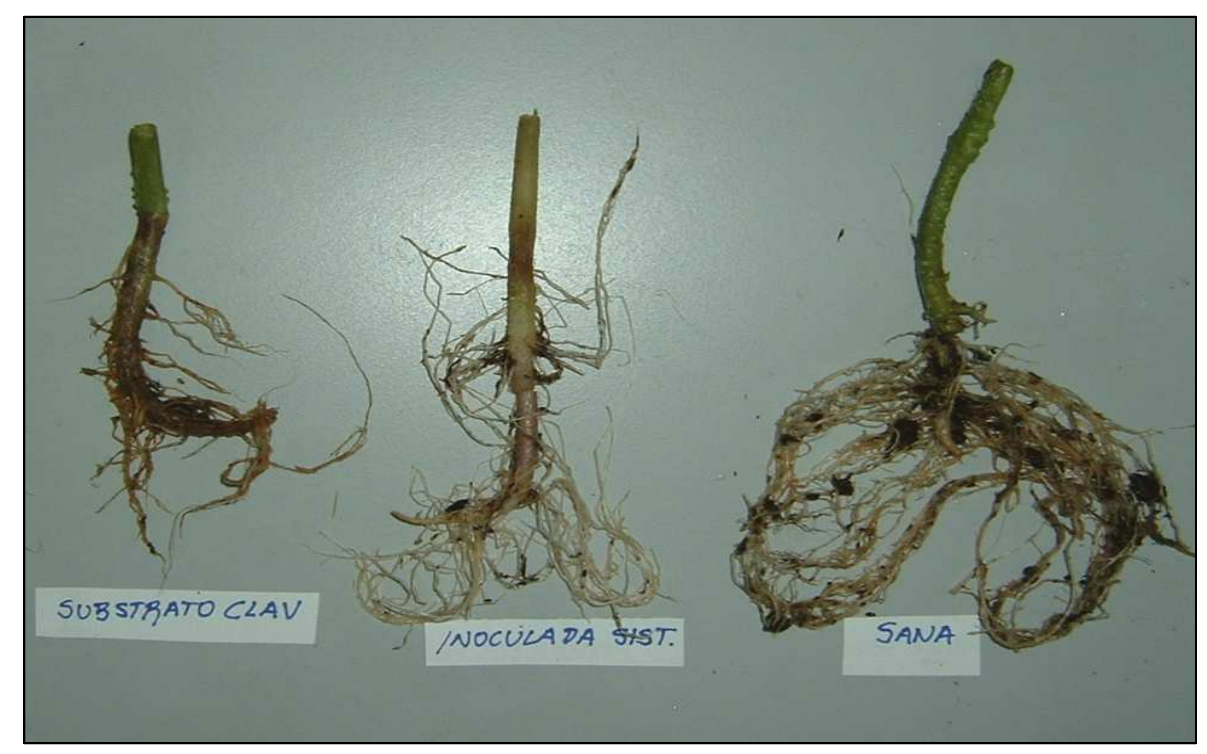

Figura 17. Comparación de daños observados en raíces de plantas de tomate dependiendo de la forma de penetración del patógeno, de izquierda a derecha: por contacto directo con substrato infectado o por inoculación infiltrando las axilas de las hojas y con una raíz de planta sana

Una vez tratadas a $25{ }^{\circ} \mathrm{C}$, los porcentajes de plantas que mostraron resultado positivo a la presencia de C.m.michiganensis tras ser analizadas por la técnica serológica DAS-ELISA transcurridas las correspondientes semanas de tratamiento en macetas, que bien permanecieron abiertas o cerradas herméticamente, se recogen en la tabla 11, considerando la "semana 0" o "semana sin ningún tipo de tratamiento térmico" como el máximo nivel de infección del que se partía.

Como se puede observar, para el estudio de la infección por C.m.michiganensis, en cada uno de los lotes preparados y coincidentes con las 
semanas de tratamiento, se ha estudiado la incidencia de la enfermedad en aquellas macetas en las que se habían incorporado distintas dosis de restos de tomate artificialmente inoculados con la bacteria seleccionada. De este modo, los estudios recogidos a continuación muestran el efecto observado en un total de 24 macetas por lote (3 dosis de material infectado con en 2 tipos de macetas y con 4 repeticiones).

Tabla 11. Incidencia de la enfermedad, expresada en porcentaje de plantas mostrando resultado positivo por DAS-ELISA a la presencia de C.m.michiganensis tras las semanas de tratamiento a $25^{\circ} \mathrm{C}$

\begin{tabular}{ccc}
\hline \multicolumn{3}{c}{$\begin{array}{c}\text { Incidencia de la enfermedad } \mathbf{2 5}^{\mathbf{}} \mathbf{C}(\boldsymbol{\%}) \\
\text { tipo de macetas }\end{array}$} \\
Semana & NB & B \\
\hline $\mathbf{0}^{\mathbf{b}}$ & 50 & 58,3 \\
$\mathbf{1}$ & 8,3 & 16,6 \\
$\mathbf{2}$ & 25 & 16,6 \\
$\mathbf{3}$ & 25 & 8,3 \\
$\mathbf{4}$ & 0 & 0 \\
$\mathbf{5}$ & 8,3 & 0 \\
$\mathbf{6}$ & 8,3 & 0 \\
\hline
\end{tabular}

${ }^{a}$ NB: macetas no encerradas en bolsas de plástico; B: macetas encerradas herméticamente en bolsas de plástico

${ }^{\text {b }}$ Semana 0 sin tratamiento térmico: máximo nivel de infección de partida

De los resultados expuestos se deduce que tras cuatro semanas de tratamiento a $25{ }^{\circ} \mathrm{C}$ no se detecta la bacteria en plantas crecidas sobre macetas conteniendo restos de tomate infectados que habían permanecido encerradas herméticamente en las bolsas de plástico durante los tratamientos. 
En cambio, tras las seis semanas de tratamiento a $25{ }^{\circ} \mathrm{C}$ en macetas que permanecieron abiertas, todavía se detecta la presencia de la bacteria en las plantas, sin resultar un método efectivo.

La principal diferencia entre macetas se encuentra en que en las que fueron encerradas no se permitía la liberación de las sustancias generadas durante la descomposición del material vegetal, reteniendo los gases con posibles efectos bactericidas. El hecho de que tras la primera semana de tratamiento el porcentaje de infección fuera mayor en las plantas crecidas sobre macetas embolsadas se relaciona con las condiciones favorables de humedad, ya que no hay que olvidar que el sustrato se lleva a capacidad de campo una vez incorporado el material vegetal y previamente a los tratamientos térmicos. Condición esta, junto con la temperatura, favorable para el desarrollo bacteriano. Por tanto, los efectos asociados a la biofumigación en relación con la disminución de la incidencia de la enfermedad se observan tras dos semanas de tratamiento a $25^{\circ} \mathrm{C}$.

Las plantas sanas trasplantadas que mostraron síntomas de infección sistémica transcurridas 6 semanas de tratamiento a $25{ }^{\circ} \mathrm{C}$ implican la presencia e importancia del inóculo bacteriano que queda asociado tanto al suelo como a los restos de cosecha.

Las diferencias específicas de los efectos de tratamientos entre las macetas abiertas o cerradas considerando las dosis ensayadas de material vegetal infectado incorporado se recogen en la figura 18, representando las medias de cuatro repeticiones por tratamiento y empleándose únicamente con propósitos comparativos, puesto que los análisis estadísticos se recogen a continuación.

Los análisis de varianza para la incidencia de la enfermedad mostraron que tanto las semanas de tratamiento como la dosis de material infectado incorporado en macetas resultaron ser factores significativos, con $\mathrm{P}<0,05$, pero no sus interacciones (Tabla 12). 

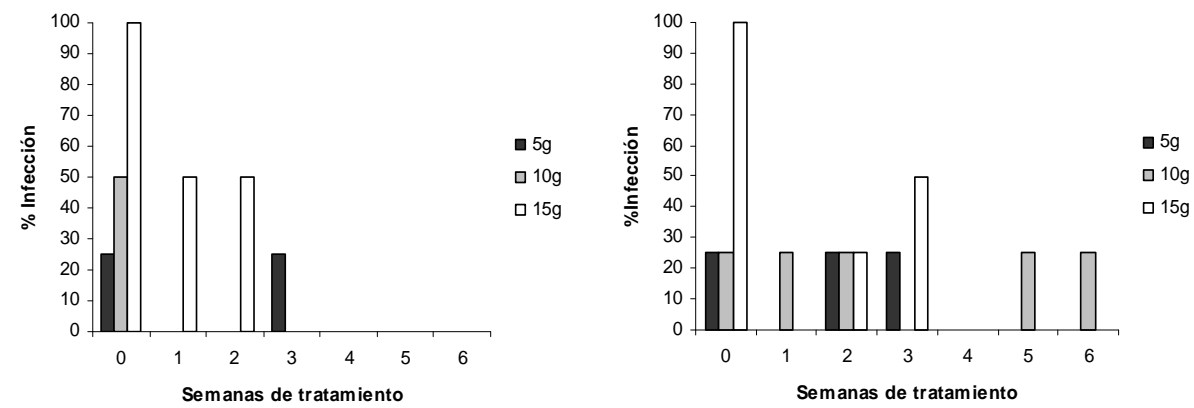

Figura 18. Efecto de los tratamientos a $25^{\circ} \mathrm{C}$ en la incidencia final de la enfermedad, expresada como porcentaje de plantas de tomate infectadas por C.m.michiganensis en macetas encerradas en bolsas de plástico (B) y en macetas sin bolsa (NB) a los 40 días del trasplante. Los histogramas representan el porcentaje de infección obtenido en cuatro repeticiones por tratamiento y dosis de material vegetal infectado e incorporado

En la tabla 13, se puede observar el resultado obtenido mediante el test LSD de Fisher $(\mathrm{P}<0,05)$ para los distintos factores considerados.

De los resultados de la tabla 13 se deduce que, aunque la bacteria se detecta en mayor proporción en macetas que permanecieron abiertas durante el tratamiento térmico, no existen diferencias significativas, de modo que el efecto que se obtiene de la descomposición del material vegetal a esta temperatura, a efectos estadísticos, será independiente del tipo de macetas empleadas.

Aún así, cabe destacar que la no existencia de diferencias significativas a nivel estadístico, se debe a un análisis de comparaciones numéricas equivalentes a diferencias entre el número de macetas con incidencia de la enfermedad. Pero, a nivel práctico, la desaparición de la enfermedad tras cuatro semanas de tratamiento a $25^{\circ} \mathrm{C}$ para las macetas encerradas resulta muy interesante si lo que se tiene en cuenta es la presencia/ausencia de la bacteria en asociación con los restos vegetales infectados que entran en contacto con plantas sanas. Habrá que considerar que los 
resultados se han obtenido en condiciones controladas, mediante el diseño de un modelo que reduce el manejo de material que sería requerido en condiciones de campo.

Los resultados obtenidos también ponen de manifiesto la diferencia que supondría el cubrir el suelo (o compactar las capas superiores) en el momento de aplicar los materiales biofumigantes, acción recomendada por distintos autores (Tello y Bello, 2002; Bello et al., 2002) favoreciendo, en este caso, los efectos asociados a la descomposición de los restos de tomate como los recogidos por Kim y Kil (2008) o por Ríos et al. (2008).

Por otra parte, si que existen diferencias significativas respecto a las dosis de material vegetal infectado que fue mezclado con el substrato, de modo que a mayor dosis, mayor infección.

Tabla 12. Resultados obtenidos del análisis de la varianza de los valores medios de la incidencia de la enfermedad para los factores dosis de material infectado, semanas de duración del tratamiento térmico y tipo de macetas (abiertas o cerradas), así como para sus interacciones, para los tratamientos a $25^{\circ} \mathrm{C}$.

\begin{tabular}{ccc}
\hline Efectos & G.L. & Valores de $\mathbf{P}^{\mathbf{a}}$ \\
\hline dosis & 2 & 0,042 \\
semanas & 6 & 0,002 \\
macetas & 1 & 0,509 \\
\hline Interacciones & & \\
\hline dosis*semanas & 12 & 0,132 \\
dosis*macetas & 2 & 0,641 \\
semanas*macetas & 6 & 0,823
\end{tabular}

${ }^{\text {a }}$ Valores de $\mathrm{P}<0,05$ implican diferencias significativas 
Tabla 13. Resultados obtenidos mediante la realización de la prueba de Fisher (LSD con $\mathrm{P}<0,05$ ) para los diferentes factores considerados en los tratamientos a $25{ }^{\circ} \mathrm{C}$ : dosis, tipo de macetas $(\mathrm{NB}=\sin$ bolsa, $\mathrm{B}=$ con bolsa) y semanas de tratamiento, transcurridos 40 días tras el trasplante. Las medias representan la incidencia de la enfermedad según el porcentaje de plantas afectadas por C.m.michiganensis.

\begin{tabular}{cccccccc} 
Temp. & Macetas & LS media & Dosis (g) & LS media & Semana & LS media \\
\hline $\mathbf{2 5}{ }^{\circ} \mathbf{C}$ & $\mathrm{B}^{\mathrm{x}}$ & $14.28 \mathrm{a}^{\mathrm{y}}$ & $10^{\mathrm{x}}$ & $10.71 \mathrm{a}$ & 4 & 0 & $\mathrm{a}$ \\
& NB & $17.85 \mathrm{a}$ & 5 & $10.71 \mathrm{a}$ & 6 & $4.46 \mathrm{a}$ \\
& & & 15 & $26.78 \mathrm{~b}$ & 5 & $4.46 \mathrm{a}$ \\
& & & & & 1 & $12.5 \mathrm{a}$ \\
& & & & & 3 & $16.66 \mathrm{a}$ \\
& & & & 2 & $20.83 \mathrm{a}$ \\
& & & & 0 & $54.16 \quad \mathrm{~b}$ \\
\hline
\end{tabular}

${ }^{\mathrm{x}}$ Cuatro repeticiones por dosis $\mathrm{y}$ tratamiento

${ }^{\mathbf{Y}}$ Los valores de cada columna seguidos por la misma letra no difieren significativamente de acuerdo con el método LSD

${ }^{\mathrm{z}}$ Incidencia de la infección expresada como porcentaje de plantas afectadas por la bacteria transcurridos 40 días tras el trasplante empleando la técnica DAS-ELISA

Sin duda, uno de los resultados más importantes se desprende de las diferencias observadas comparando la duración del tratamiento térmico ya que el máximo nivel de infección obtenido para la semana 0 o "sin tratamiento" disminuye con los tratamientos desde la primera semana. Aunque no se observen diferencias significativas entre las semanas de tratamiento si que disminuye la incidencia de la enfermedad conforme estas avanzan, de modo que la menor incidencia se obtiene tras la quinta y sexta semanas de exposición a $25{ }^{\circ} \mathrm{C}$. Como dato anómalo se considera la no infección observada tras cuatro semanas de tratamiento. Pero el hecho de que de nuevo aparezcan plantas afectadas en semanas 
posteriores implica que la bacteria nunca se controló a $25^{\circ} \mathrm{C}$ tras 6 semanas de tratamiento, interpretando los análisis estadísticos recordando que no se consideran diferencias significativas entre el tipo de macetas, embolsadas y no embolsadas.

\subsubsection{Tratamiento de biosolarización en macetas: $45^{\circ} \mathrm{C}$}

Cabe recordar que se denomina biosolarización al efecto conjunto de biofumigación y solarización, y por lo que el primer efecto de la combinación de ambas técnicas supondría que se alcanzasen temperaturas mayores en los suelos o substratos tratados. En este trabajo se consideró que una temperatura de $45^{\circ} \mathrm{C}$ sería fácilmente alcanzable en caso de combinación de ambas técnicas, considerando que en condiciones de campo estos valores serían fácilmente superados.

En la tabla 14 se recogen los porcentajes de plantas con resultado positivo a la presencia de C.m.michiganensis. Tras cuatro semanas de tratamiento a $45^{\circ} \mathrm{C}$, ya no se detecta la presencia de la bacteria en las plantas transcurridos 40 días desde el transplante en los dos tipos de macetas ensayadas (abiertas y cerradas). A partir de los resultados empleados y al corroborarse con las repeticiones realizadas de los tratamientos correspondientes a la zona de corte de la detección (cuarta y quinta semanas) se desestimó la sexta semana de ensayo. De este modo, para el estudio de biosolarización, bajo condiciones controladas, los ensayos comprendían desde una semana hasta cinco semanas de tratamiento térmico a $45^{\circ} \mathrm{C}$.

De nuevo se observa que el efecto de control de la enfermedad, a partir de las técnicas de detección empleadas, es más rápido en las macetas que permanecieron encerradas de forma hermética en bolsas de plástico y reteniendo las sustancias volátiles procedentes de la descomposición del material vegetal añadido, que en el caso de las macetas que permanecieron abiertas. En este caso, dos semanas de tratamiento a $45^{\circ} \mathrm{C}$ para macetas encerradas y cuatro semanas de tratamiento a $45{ }^{\circ} \mathrm{C}$ para las macetas que permanecieron abiertas, son suficientes para controlar la enfermedad causada por C.m.michiganensis. 
Tabla 14. Incidencia de la enfermedad, expresada en porcentaje de plantas mostrando resultado positivo por DAS-ELISA a la presencia de C.m.michiganensis tras las semanas de tratamiento a $45^{\circ} \mathrm{C}$

\begin{tabular}{ccc}
\hline \multicolumn{3}{c}{$\begin{array}{c}\text { Incidencia de la enfermedad } 4^{\mathbf{o}} \mathbf{C}(\%) \\
\text { tipo de macetas }\end{array}$} \\
Semana & NB & B \\
\hline $\mathbf{0}^{\mathbf{b}}$ & 83 & 75 \\
$\mathbf{1}$ & 0 & 8,3 \\
$\mathbf{2}$ & 16,6 & 0 \\
$\mathbf{3}$ & 25 & 0 \\
$\mathbf{4}$ & 0 & 0 \\
$\mathbf{5}$ & 0 & 0 \\
\hline
\end{tabular}

${ }^{a}$ NB: macetas no encerradas en bolsas de plástico; B: macetas encerradas herméticamente en bolsas de plástico

${ }^{\mathbf{b}}$ Semana 0 sin tratamiento térmico: máximo nivel de infección de partida

Las diferencias específicas de los efectos de los tratamientos en la incidencia de la enfermedad entre los factores considerados: tipos de macetas (abiertas o cerradas) y dosis de material vegetal infectado añadido, se recogen en la figura 19, representando las medias de cuatro repeticiones por tratamiento.

Los análisis de varianza para la incidencia de la enfermedad mostraron, al igual que para los tratamientos a $25^{\circ} \mathrm{C}$, que tanto las semanas de tratamiento como la dosis de material infectado añadido en las macetas resultaron factores significativo con $\mathrm{P}<0,05$, pero no así ninguna de las interacciones (Tabla 14). 

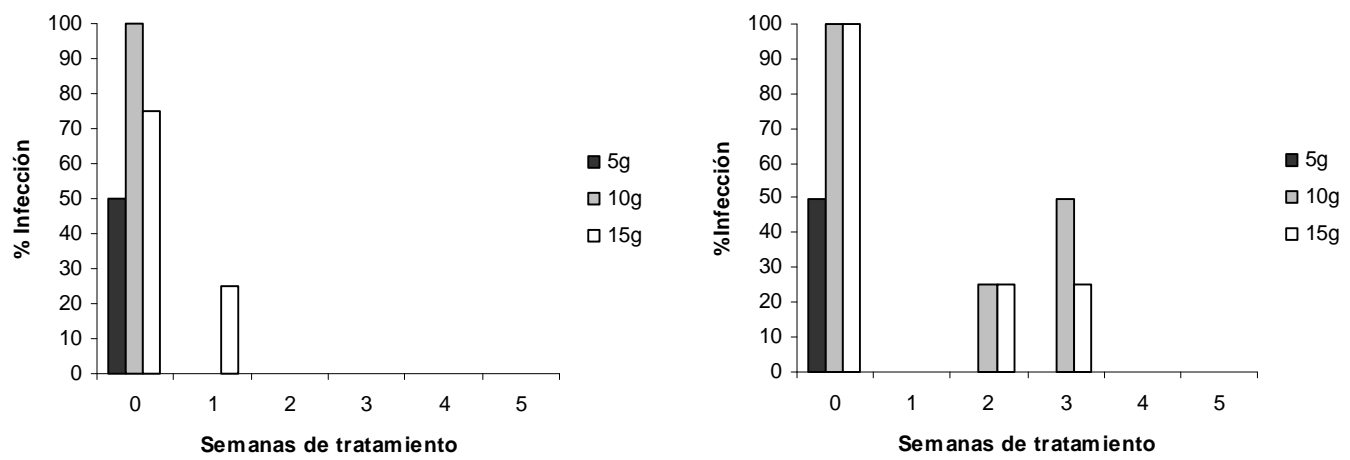

Figura 19. Efecto de los tratamientos a $45{ }^{\circ} \mathrm{C}$ en la incidencia final de la enfermedad, expresada como porcentaje de plantas de tomate infectadas por C.m.michiganensis en macetas encerradas en bolsas de plástico (B) y en macetas sin bolsa (NB) a los 40 días del trasplante. Los histogramas representan el porcentaje de infección obtenido en cuatro repeticiones por tratamiento y dosis de material vegetal infectado e incorporado

Tabla 15. Resultados obtenidos del análisis de la varianza de los valores medios de la incidencia de la enfermedad para los factores dosis de material infectado, semanas de duración del tratamiento térmico y tipo de macetas (abiertas o cerradas), así como para sus interacciones

Para los tratamientos a $45^{\circ} \mathrm{C}$.

\begin{tabular}{ccc}
\hline Efectos & G.L. & Valores de $\mathbf{P}^{\mathbf{a}}$ \\
\hline dosis & 2 & 0,016 \\
semanas & 5 & 0,000 \\
macetas & 1 & 0,064 \\
\hline Interacciones & & \\
\hline dosis*semanas & 10 & 0,109 \\
dosis*macetas & 2 & 0,339 \\
semanas*macetas & 5 & 0,129
\end{tabular}

${ }^{a}$ Valores de $\mathrm{P}<0,05$ implican diferencias significativas 
En la tabla 16, se recoge el resultado obtenido mediante el test LSD de Fisher $(\mathrm{P}<0,05)$ para los distintos factores considerados.

Tabla 16. Resultados obtenidos mediante la realización de la prueba de Fisher (LSD con $\mathrm{P}<0,05)$ para los diferentes factores considerados en los tratamientos a $45{ }^{\circ} \mathrm{C}$ : dosis, tipo de macetas $(\mathrm{NB}=\sin$ bolsa, $\mathrm{B}=$ con bolsa) y semanas de tratamiento, transcurridos 40 días tras el trasplante. Las medias representan la incidencia de la enfermedad según el porcentaje de plantas afectadas por C.m.michiganensis.

\begin{tabular}{cccccccc}
\hline Temp. & Macetas & LS media & Dosis (g) & LS media & Semana & LS media \\
\hline $\mathbf{4 5}^{\circ} \mathbf{C}$ & $\mathrm{B}^{\mathrm{x}}$ & $13.88 \mathrm{a}^{\mathrm{y}}$ & $5^{\mathrm{x}}$ & $8.33 \mathrm{a}$ & 5 & 0 & $\mathrm{a}$ \\
& NB & $20.83 \mathrm{a}$ & 15 & $20.83 \mathrm{~b}$ & 4 & 0 & $\mathrm{a}$ \\
& & & 10 & $22.91 \mathrm{~b}$ & 1 & $4.16 \mathrm{a}$ \\
& & & & & 2 & $8.33 \mathrm{a}$ \\
& & & & & 3 & $12.5 \mathrm{a}$ \\
& & & & & 0 & $79.16 \mathrm{~b}$ \\
\hline
\end{tabular}

${ }^{\mathrm{x}}$ Cuatro repeticiones por dosis y tratamiento

Y Los valores de cada columna seguidos por la misma letra no difieren significativamente de acuerdo con el método LSD

${ }^{\mathrm{Z}}$ Incidencia de la infección expresada como porcentaje de plantas afectadas por la bacteria trasnscurridos 40 días tras el trasplante empleando la técnica DAS-ELISA

De los resultados de la tabla 16 se deduce que, tal como ocurría en el tratamiento a $25{ }^{\circ} \mathrm{C}$, aunque la bacteria se detecte en mayor proporción en el caso de plantas crecidas sobre macetas que permanecieron abiertas durante los tratamientos, a efectos estadísticos, no existen diferencias significativas.

Respecto a las dosis introducidas, si que hay diferencias, pero el comportamiento a $45{ }^{\circ} \mathrm{C}$ resulta similar para las dosis mayores de $10 \mathrm{~g}$ y $15 \mathrm{~g}$, diferenciándose la de $5 \mathrm{~g}$ con la que la incidencia de la enfermedad es mucho 
menor. Se considerará, por tanto, que las dosis de $5 \mathrm{~g}$ de material vegetal infectados por cada $500 \mathrm{~g}$ de substrato resultan significativamente menos infectivas que el resto, observándose un mayor efecto térmico y relacionándose de forma directa con la cantidad de material vegetal adicionada, pues al tener menos cantidad de materia orgánica, esta se descompone antes resultando la dosis menos infectiva.

$\mathrm{Al}$ igual que en el caso de tratamientos a $25^{\circ} \mathrm{C}$, el estudio estadístico de la incidencia de la enfermedad en relación con las semanas de duración de los tratamientos, indica que se observan reducciones significativas ya desde la primera semana a $45^{\circ} \mathrm{C}$. Este resultado concuerda con estudios previos que señalan a las elevadas temperaturas alcanzadas en el suelo como el factor que ejerce el efecto adverso más importante sobre el inóculo de C.m.michiganensis (Gleason et al., 1991; Antoniou et al., 1995; Basu, 1970).

El número de plantas enfermas se reduce hasta alcanzar las semanas 4 y 5 donde ya no se detecta ninguna. De nuevo, aunque estadísticamente los estudios numéricos no muestren diferencias significativas entre la duración de tratamientos, a nivel práctico si que resulta interesante, puesto que entre la ausencia o presencia de plantas enfermas si que hay claras diferencias.

Tras cuatro semanas de tratamiento a $45^{\circ} \mathrm{C}$, se controla la incidencia de la enfermedad causada en plantas por C.m.michiganensis y transmitida a través de restos de material vegetal infectados que se incorporan al substrato.

A partir de los resultados se puede afirmar que la enfermedad ha sido erradicada pero, basándose en la definición de Noble y Roberts (2004), en este trabajo también se considerará erradicación como la no detección de patógenos mediante las técnicas seleccionadas y con los límites de sensibilidad propios de estos métodos, lo que no implica que esté totalmente controlada.

La especificación anterior adquiere un papel relevante en la investigación debido a las condiciones en las que se ha llevado a cabo el ensayo de biocontrol, puesto que conviene insistir en que se trata de un ensayo bajo condiciones controladas y de dimensiones limitadas debido a la condición de manejo de una 
bacteria de cuarentena en Europa, sugiriendo que los resultados obtenidos serán de vital importancia para asociarlos con el comportamiento bacteriano en caso de detectarse una infección a nivel de campo.

Por otra parte, aunque hay que referirse con cautela respecto a la erradicación bacteriana conseguida, estos resultados pueden adicionarse a la información aportada por otros autores respecto a la supervivencia de esta bacteria en suelos y substratos (Strider, 1967; Trevors y Finnen, 1990; Gleason et al., 1991), al tratarse de información muy variada dependiendo de distintos factores como la zona de estudio y condiciones de humedad, $\mathrm{pH}$, tipo de suelo o existencia de antagonismo bacteriano.

Aún así, pese a la falta de uniformidad de resultados publicados, los obtenidos en este trabajo, tanto a $25^{\circ} \mathrm{C}$ como a $45^{\circ} \mathrm{C}$, concuerdan con los de Basu (1970) que no detectó la bacteria en suelos en asociación con restos de cosecha tras tres semanas de tratamiento en un rango de temperaturas comprendido entre $25^{\circ} \mathrm{C}$ y $35^{\circ} \mathrm{C}$. A partir de este resultado, este autor ya sugería tratamientos térmicos a altas temperaturas durante 4 semanas antes de la siembra.

Además, en 1995, Antoniou et al., indicaron la solarización (ensayada sin la adición de material vegetal) como técnica efectiva en el control de la enfermedad causada por C.m.michiganensis, reduciendo su incidencia tras tratamientos de 6 semanas.

Los resultados obtenidos en este trabajo, aportan nueva información a los anteriormente mencionados, e incluso sugiriendo la combinación de ambos que reduciría la duración aconsejada de los tratamientos de solarización: la incorporación de restos de tomate infectados al suelo, sometido posteriormente a una solarización durante cuatro semanas empleando láminas de PE transparente, alcanzando temperaturas de $45^{\circ} \mathrm{C}$, o superiores.

Debido a los resultados obtenidos y para reducir riesgos a la hora de aplicación de las técnicas en campo, se decidió continuar investigando el 
comportamiento de la bacteria en las condiciones de ensayo, estudios que se recogen a continuación.

\subsection{Introducción y recuperación de C.m.michiganensis en substratos infectados artificialmente}

La recuperación de las colonias bacterianas de C.m.michiganensis a partir del substrato infectado se realizó para las dos temperaturas de estudio $\left(25\right.$ y $\left.45^{\circ} \mathrm{C}\right)$ incluyendo el seguimiento semanal de las distintas colonias observadas en placas.

Tras los tratamientos a $25^{\circ} \mathrm{C}$ (tabla 17), las poblaciones de la bacteria patógena en el medio de crecimiento general YDA decrecieron bruscamente identificándose hasta la segunda semana de tratamiento. Sin embargo, en el caso del medio selectivo D2 se observaba una disminución gradual de la densidad poblacional de C.m.michiganensis hasta la tercera semana, ya que tras cuatro semanas de tratamiento a $25^{\circ} \mathrm{C}$ ya no se detecta su crecimiento en las placas.

La identificación y conteo de las colonias se realizaba de forma visual, obteniéndose cultivos puros que se analizaban por DAS-ELISA caracterizándose las colonias correspondientes a C.m.michiganensis por su coloración amarilla, en los dos medios de crecimiento ensayados.

Las soluciones bacterianas preparadas a partir de los cultivos puros con resultado positivo a la técnica ELISA e inoculadas en hojas de tabaco dieron reacciones de fitopatogenicidad positivas, por lo que se deduce que tras tres semanas de tratamiento a $25^{\circ} \mathrm{C}$, las células de C.m.michiganensis introducidas en el substrato como células libres mediante la adición directa de la solución bacteriana al substrato, permanecen infectivas.

Tras los tratamientos a $45{ }^{\circ} \mathrm{C}$ nunca se detectaron colonias de C.m.michiganensis en las placas. 
Tabla 17. Promedio del conteo de colonias de C.m.michiganensis procedentes del substrato tratado tras un periodo de 6 semanas a $25^{\circ} \mathrm{C}$

\begin{tabular}{|c|c|c|c|c|c|c|c|}
\hline \multirow[t]{3}{*}{ Medio nutritivo } & \multicolumn{7}{|c|}{ Log efu g ${ }^{-1}$ substrato $^{\text {a }}$} \\
\hline & \multicolumn{7}{|c|}{ Sem. tratam. $25^{\circ} \mathrm{C}$} \\
\hline & 0 & 1 & 2 & 3 & 4 & 5 & 6 \\
\hline YDA & 5,316 & 0 & 4,39 & 0 & 0 & 0 & 0 \\
\hline D2 & 4,748 & 5,819 & 3,867 & 3,238 & 0 & 0 & 0 \\
\hline
\end{tabular}

${ }^{\text {a }}$ Promedio del conteo de ufc $\mathrm{g}^{-1}$ de substrato en placas Petri a partir del método de las diluciones seriadas, con 5 diluciones y 2 repeticiones por medio nutritivo ensayado $(5 \times 2 \times 2)$

Los resultados obtenidos se asemejan a los obtenidos por Echandi (1971), que indicaba que C.m.michiganensis podía sobrevivir durante dos semanas al introducirlo en el suelo como células libres mientras que para Trevors y Finnen (1990), y aplicando una metodología similar a la expuesta en este trabajo, la bacteria no se detectó tras cuatro semanas de tratamiento a $22^{\circ} \mathrm{C}$.

Además de los resultados obtenidos tras su investigación, Trevors y Finnen (1990) recogen más datos sobre la supervivencia de la bacteria en el suelo indicando que en otros trabajos se afirmaba que puede permanecer en el suelo durante 8 años, y sugirieron que la presencia del patógeno varía entre las distintas cepas de C.m.michiganensis dependiendo de distintos factores añadiendo a las condiciones ambientales y características del suelo, referidas por Basu (1970), otros como la competitividad con bacterias de crecimiento rápido, competición por nutrientes, el nicho en el suelo y la acción de nematodos que actúan como predadores.

Por otra parte, respecto a la no detección del patógeno tras $45^{\circ} \mathrm{C}$, resultaría interesante considerar el comportamiento observado en los suelos hortícolas que 
han sido desinfectados tal y como lo recoge Tello (1977). Según este autor, la recuperación de la actividad microbiana de un suelo es más rápida tras un tratamiento a elevadas temperaturas, en su caso con vapor de agua, que cuando se emplean fumigantes biocidas. En el proceso de reactivación intervendrán los microorganismos que ocupan zonas del suelo no alcanzadas por la desinfección así como zonas de suelo o aire limítrofes y, sobre todo, aquellos microorganismos que no han sido dañados por la desinfección.

A partir de los resultados observados in vitro, al someter al substrato a temperaturas de $45^{\circ} \mathrm{C}$, se habrá producido una desinfección del mismo tal y como indica Tello (1977) que citando a Kreutzer señala que la recolonización de suelos desinfectados se produce de la siguiente forma: en primer lugar se produce una reactivación y desarrollo de las bacterias, sobre todo las amonificantes, posteriormente iniciarán su recolonización los actinomicetos y por último, se produce la recolonización de los hongos. Entre estos últimos se desarrollarán primero las especies que emplean azúcares y ácidos libres de origen animal como Mortiriella, Phytium, Mucor, Aspergillus, Rhizopus, etc.

Tras los tratamientos a $45^{\circ} \mathrm{C}$, en las placas sembradas a partir de las soluciones preparadas con $1 \mathrm{~g}$ de substrato y crecidas a $25^{\circ} \mathrm{C}$ durante una semana, sí que se observó el crecimiento de distintas bacterias (cuyo seguimiento semanal se recoge a continuación) y, en ocasiones, se observó la invasión de placas por Rhizopus, en concreto en medio nutritivo YDA y tras 4 semanas de tratamiento a $45{ }^{\circ} \mathrm{C}$ (figura 20). Comportamiento que puede relacionarse con la reactivación de patógenos que han sobrevivido al tratamiento, ya que distintas especies de Rhizopus como R.azygosporus, $R$. microsporus, $R$. oligosporus o $R$. oryzae soportan temperaturas de $45^{\circ} \mathrm{C}$ o incluso superiores pero siempre inferiores a $50{ }^{\circ} \mathrm{C}$ (Rusmin y Ko, 1974; y consulta en la página de Mycology 2008), comportamiento también relacionado con la futura recolonización del medio desinfectado

Al haberse realizado el seguimiento semanal de los distintos tipos de colonias que se observaron en las placas, se evaluó el efecto de los tratamientos 
térmicos también sobre estas. Así, el número de otras colonias que crecieron tras los tratamientos en el medio de cultivo selectivo D2, como cabía esperar, era inferior al observado en el medio para un crecimiento general YDA (figura 21), observando que tras las semanas de tratamiento, a ambas temperaturas, los niveles de presencia de determinadas bacterias se mantienen en altas densidades poblacionales.

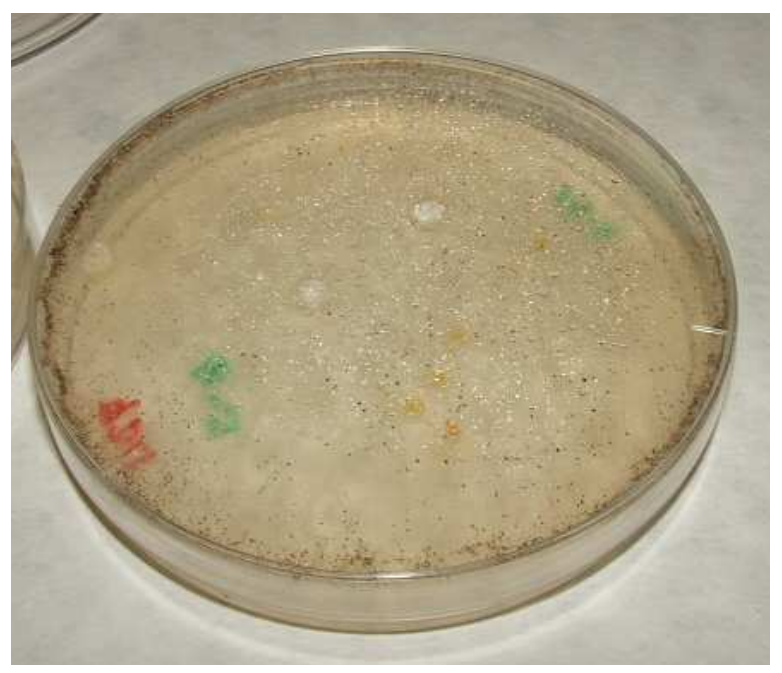

Figura 20. Rhizopus creciendo en placa de YDA sembrada con $100 \mu$ de la dilución $10^{5}$ del substrato tratado durante 4 semanas a $45^{\circ} \mathrm{C}$

Algunos de los cultivos puros de estas bacterias se identificaron como Paenibacillus sp. y Brevibacillus sp. por PCR y secuenciación (GenBank Accessions No. EU857426 y No. EU857427, respectivamente).

Estas bacterias han sido citadas en diferentes estudios por mostrar antibiosis (actividad antibiótica) frente algunos organismos fitopatógenos. Así, Sturz et al. (2005) cuando recogen en largas listas el porcentaje de actividad de numerosas especies bacterianas contra Phytopththora erythroseptica, Fusarium 
oxysporum y Streptomyces scabies, también citan distintas especies tanto de Paenibacillus como de Brevibacillus, llamando la atención la actividad antibiótica frente a estos mismos patógenos asociada a la bacteria en estudio C.m.michiganensis. Es importante señalar que esta actividad la detectaron en ensayos realizados in vitro, y las bacterias procedían de aislamientos obtenidos de dos zonas: del suelo cercano a las raíces de los cultivos de patata estudiados así como del interior de las mismas ya que los autores compararon, en estas zonas, la frecuencia en que se detectaban las múltiples bacterias con actividad de antibiosis y que favorecen la defensa de las plantas frente a los patógenos que las atacan de forma sistémica.

El efecto de los tratamientos térmicos en la dinámica poblacional de C.m.michiganensis y del resto de colonias evaluadas a $25{ }^{\circ} \mathrm{C}$ (figura 22) implica diferencias entre estas colonias, especialmente respecto a su comportamiento en función del medio nutritivo del que dispongan. Los análisis de regresión para estos resultados (siguiendo un modelo polinomial), muestran un descenso brusco en las colonias patógenas en ambos medios nutritivos, mientras que las poblaciones de colonias saprofitas permanecieron prácticamente constantes tras las semanas de tratamiento a $25^{\circ} \mathrm{C}$. 

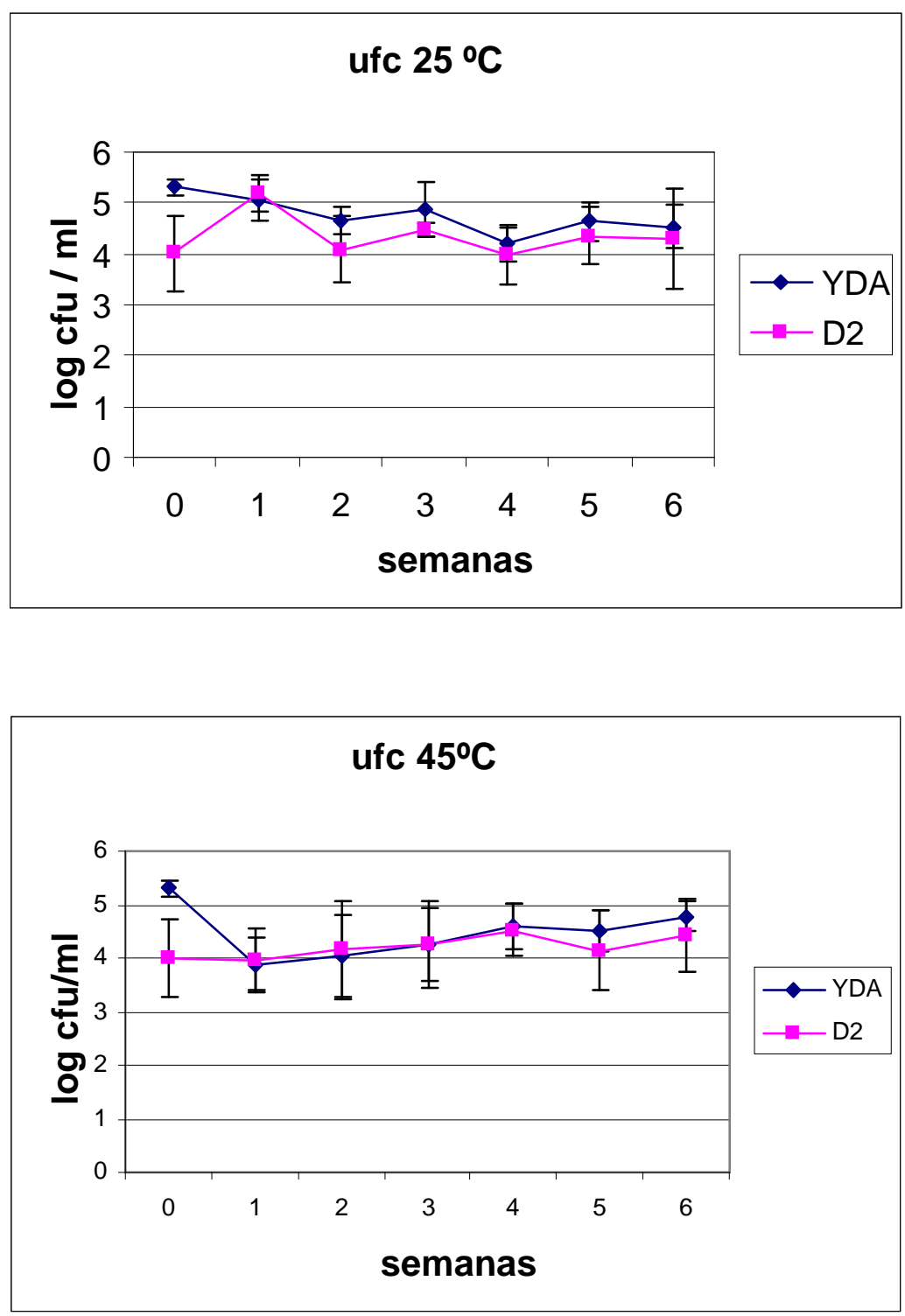

Figura 21. Crecimiento de colonias bacterianas diferentes a C.m.michiganensis en los medios de crecimiento tras los tratamientos térmicos a $25^{\circ} \mathrm{C}$ y $45^{\circ} \mathrm{C}$ 


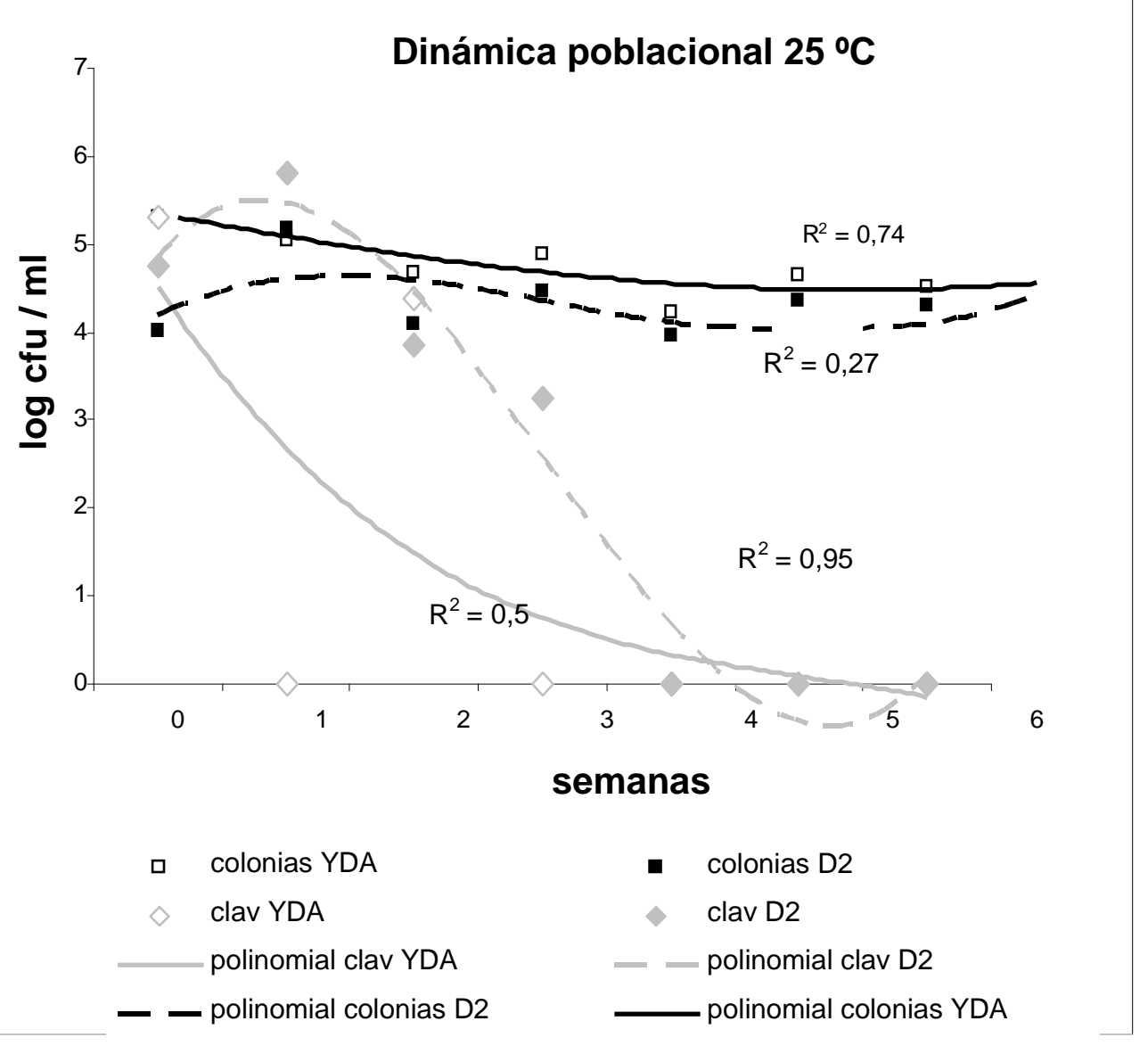

Figura 22. Efecto del tratamiento térmico a $25{ }^{\circ} \mathrm{C}$ en la dinámica poblacional de C.m.michiganensis y otras colonias de bacterias en los medios nutritivos ensayados (YDA y D2).

\subsection{Determinación de la supervivencia de C.m.michiganensis en asociación con tejidos vegetales}

Una vez estudiado el comportamiento de C.m.michiganensis en el substrato elegido y en el que se había introducido como células libres por medio de una solución bacteriana, se estudió el comportamiento bacteriano en asociación con los restos de tomate (tallos artificialmente inoculados, confirmando su infección por 
DAS-ELISA) en dos circunstancias: introduciendo dichos restos vegetales en el substrato e introduciéndolos directamente en los viales de ensayo, intentando diferenciar así el efecto ejercido por el substrato en los tratamientos térmicos.

Las suspensiones que se obtenían directamente a partir del material vegetal recuperado y extraído del substrato tratado a $25^{\circ} \mathrm{C}$, dieron resultado positivo mediante la técnica DAS-ELISA hasta la quinta semana de tratamiento, mientras que tras los tratamientos a $45^{\circ} \mathrm{C}$, los resultados serológicos nunca fueron positivos a la detección de C.m.michiganensis.

Tras la inoculación de las soluciones bacterianas procedentes de los tratamientos a $25{ }^{\circ} \mathrm{C}$ en hojas de tabaco, se obtuvieron reacciones positivas de patogenicidad hasta la cuarta semana de tratamiento.

Estos resultados se han diferenciado por las temperaturas de tratamiento, pero para algunos autores como Moffet y Word (1984) la recuperación de la bacteria asociada a restos vegetales depende del tipo de suelo o substrato, variando en más de 12 semanas según se trate de suelos más arenosos o más arcillosos. En este caso, para substratos a partir de turba-arena, la bacteria permanece infectiva durante 4 semanas en asociación con tallos de tomate, pero sí que resulta importante la temperatura a la que se han sometido, pues si se detecta tras los tratamientos a $25^{\circ} \mathrm{C}$ pero no a $45^{\circ} \mathrm{C}$, en condiciones de igualdad de substrato, el efecto térmico puede ser el responsable, lo que también explicaría la diferencia observada respecto a los resultados obtenidos por Chang et al. (1990) según los cuales, en asociación con los tallos de tomate C.m.michiganensis se pudo recuperar tras 196 días desde la infección.

Respecto a los restos vegetales sin substrato, tras los tratamientos a $25^{\circ} \mathrm{C}$, el ELISA reveló resultados positivos a la presencia de C.m.michiganensis durante todas las semanas de tratamiento, incluyendo la sexta y última. Sin embargo, tras los tratamientos a $45^{\circ} \mathrm{C}$, el resultado se mostró positivo hasta la cuarta semana de tratamiento, no detectándose la bacteria patógena tras las dos últimas semanas de ensayo. 
Tras la inoculación de las soluciones bacterianas procedentes de los tratamientos a $25^{\circ} \mathrm{C}$ y a $45{ }^{\circ} \mathrm{C}$ en hojas de tabaco, se obtuvieron reacciones positivas de patogenicidad hasta la cuarta semana de tratamiento. Es este resultado el que pone de manifiesto que la técnica serológica ELISA detecta la presencia de las bacterias, pero no su nivel de patogenicidad, lo que se confirmaría en apartados posteriores, pero para la bacteria $R$. solanacearum, ya que hay casos en los que las formas bacterianas viables no son cultivables bajo condiciones adversas, pero cuando estas mejoran pueden recuperar de nuevo su patogenicidad.

Los resultados de las siembras en placa de las soluciones bacterianas obtenidas a partir de estos residuos vegetales y siguiendo el método de las diluciones seriadas, mostraron reacciones de antibiosis (figura 23). Las bacterias implicadas en estas reacciones se identificaron mediante PCR y secuenciación como diferentes cepas de Bacillus subtilis (GenBank Accesión No. EU857428). La figura 23 muestra el efecto bacteriostático y no bactericida puesto que se frena el crecimiento de las bacterias permaneciendo intactas, sin destrucción pero sin avance.

A partir de estos resultados, se enfrentaron los cultivos de Bacillus subtilis y C.m.michiganensis en placas Petri (figura 24) obteniéndose zonas de inhibición de crecimiento.

El efecto de Bacillus subtilis frente a C.m.michiganensis también se ha estudiado por otros autores. Así, Girish y Umesha (2005) comparando el efecto de diferentes rizobacterias promotoras del crecimiento (incluyendo distintas cepas de B. pumilus, B. subtilis, B. amyloliquefaciens y Brevibacillus brevis), midiendo el nivel de infección encontraron que la incidencia de chancro bacteriano, en plantas de tomate y en condiciones de invernadero, disminuía e incluso mejoraba el vigor de las plántulas en presencia de B. subtilis, B. amyloliquefaciens y Brevibacillus brevis. La disminución de la enfermedad se asoció con el incremento de determinadas enzimas como PAL (Phenylalanine Ammonia Lyase) y también de fenoles totales. 
En función de todos los resultados expuestos y según Trevors y Finnen (1990), la supervivencia de las bacterias en el suelo es muy difícil de determinar de modo que los resultados obtenidos se han de considerar como aproximaciones, aportando una valiosa información ecológica para un adecuado manejo agrario.

Como conclusiones, en asociación con el material vegetal C.m.michiganensis resulta patógena hasta la cuarta semana de tratamiento tanto a 25 como a $45^{\circ} \mathrm{C}$, de modo que la temperatura no será un factor determinante, en este caso. En cambio, al introducir la bacteria libremente en el substrato nunca se recupera tras tratar a $45{ }^{\circ} \mathrm{C}$ pero a $25{ }^{\circ} \mathrm{C}$ se detecta hasta la tercera semana de tratamiento observándose, además, reacciones de antibiosis en placa, por lo que los conteos de la bacteria patógena pueden haberse visto influidos por estas reacciones. En función con estos resultados, se puede explicar lo ocurrido en el bioensayo en macetas, ya que la detección de la bacteria hasta la tercera semana de tratamiento a $45^{\circ} \mathrm{C}$ se debe a que ha permanecido activa y virulenta en asociación con el material vegetal, mientras que a $25^{\circ} \mathrm{C}$ no se controla tras 6 semanas de tratamiento, por la misma razón. El hecho de que las macetas permanezcan abiertas o cerradas marca una diferencia, por lo que resulta efectivo la retención de los gases procedentes de la biodescomposición del material vegetal y favorecer las temperaturas elevedas en el terreno, cercanas a $45^{\circ} \mathrm{C}$, equivalente al tratamiento de la denominada como biosolarización. 


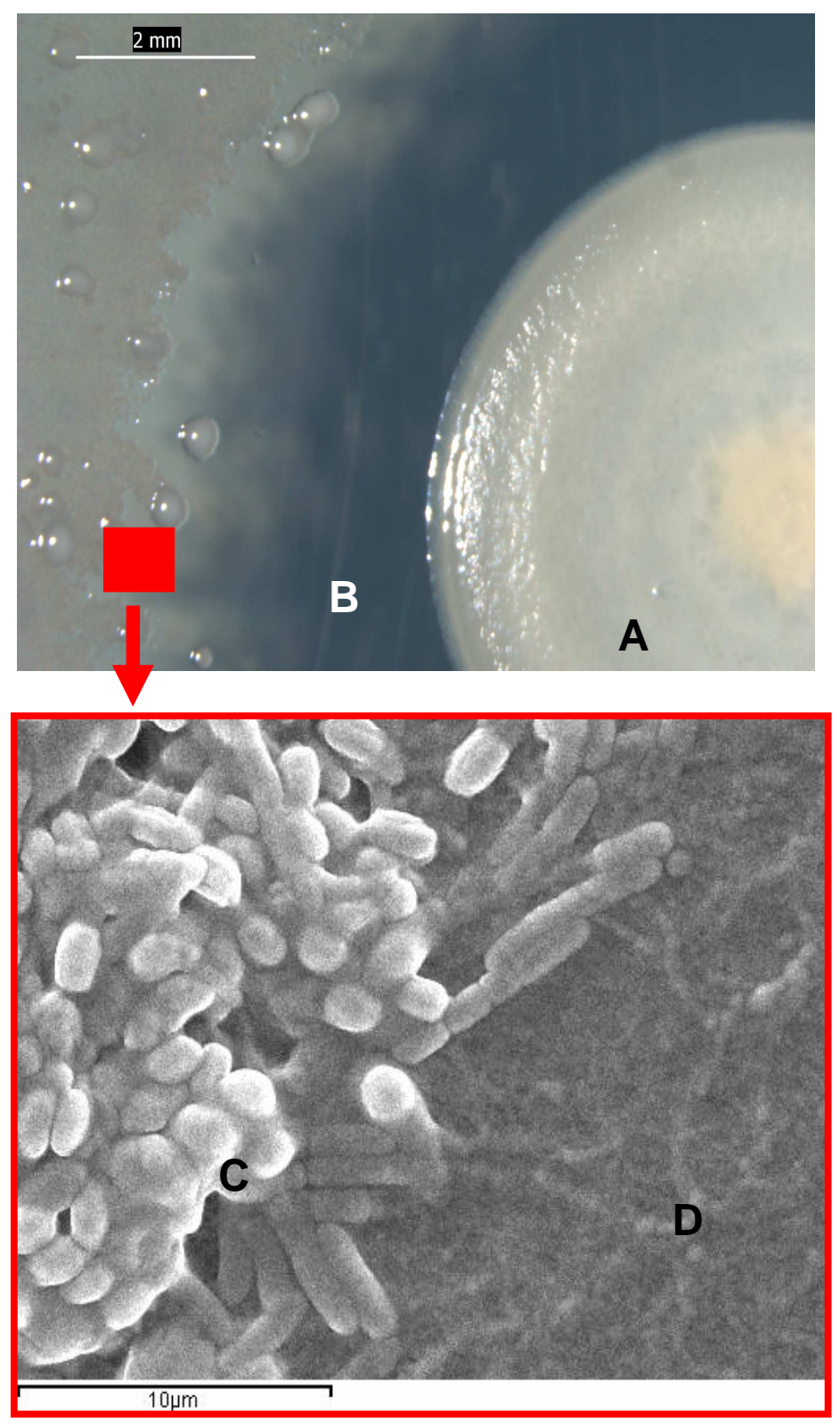

Figura 23. Reacción de antibiosis observada bajo lupa y SEM en placas de YDA. La bacteria responsable de la inhibición de crecimiento (A) se identificó como Bacillus subtilis (A: Bacillus subtilis; B: zona de inhibición de crecimiento) y zona de inhibición observada por SEM (C: colonia bacteriana; D: zona de inhibición causada por Bacillus subtilis) 


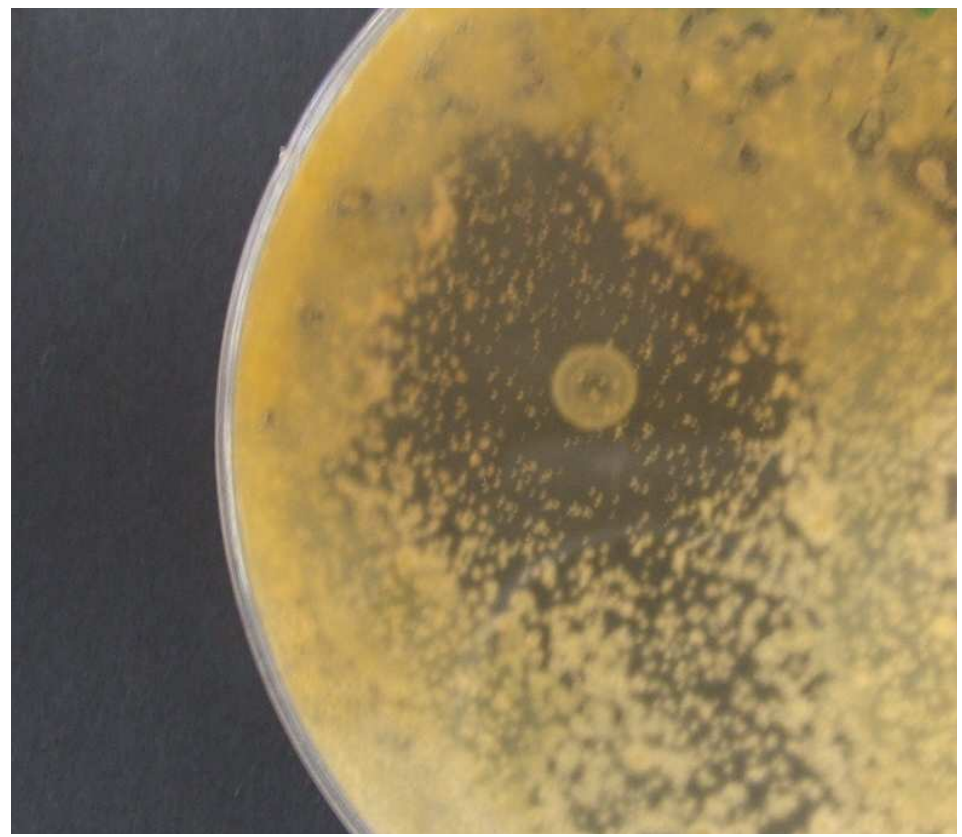

Figura 24. Antagonismo in Vitro entre Bacillus subtilis y C.m.michiganensis. B. subtillis se aplicó en la placa de KB a partir de una gota de $5 \mu$ de una suspensión del cultivo puro $\left(10^{7} \mathrm{cfu} \mathrm{ml}^{-1}\right)$. Tras $48 \mathrm{~h}$ de crecimiento a $28{ }^{\circ} \mathrm{C}$ una suspensión de C.m.michiganensis $\left(10^{7} \mathrm{cfu} \mathrm{ml}^{-1}\right)$ fue pulverizada sobre las placas. Tras $24 \mathrm{~h}$ se observaba la reacción (Boer et al., 1999).

\section{Ralstonia solanacearum}

\subsection{Crecimiento en placa y test de patogenicidad en tabaco}

Las bacterias se hicieron crecer en medio selectivo TTC y en medio general YDA, identificándose las colonias de $R$. solanacearum, principalmente, por su coloración y morfología características (figura 25). En los dos medios nutritivos 
ensayados, las placas cultivadas se mantenían a $28^{\circ} \mathrm{C}$, de calor seco, creciendo en $48 \mathrm{~h}$.

Las colonias pueden adquirir morfologías diferentes, así, en el medio YDA, pueden ser mucosas o no mucosas pero ambas con coloraciones de blanquecinas a cremosas mientras en TTC, adquieren coloraciones rojizas en el centro manteniéndose blanquecinas en los bordes variando también en su consistencia.

Respecto a la diferencia entre los distintos tipos de colonias se debe principalmente a la virulencia de las cepas así como a la cantidad de exopolisacaridos EPS (Caruso, 2005). Esta misma autora indica que las células bacterianas formadoras de colonias mucosas se describen como no flageladas e inmóviles, mientras que las no mucosas, y menos virulentas, están formadas por bacterias altamente móviles y flageladas.

Todas las colonias aisladas en la realización de este trabajo, y como se muestra en la figura 25 , han adquirido consistencias más o menos mucosas.
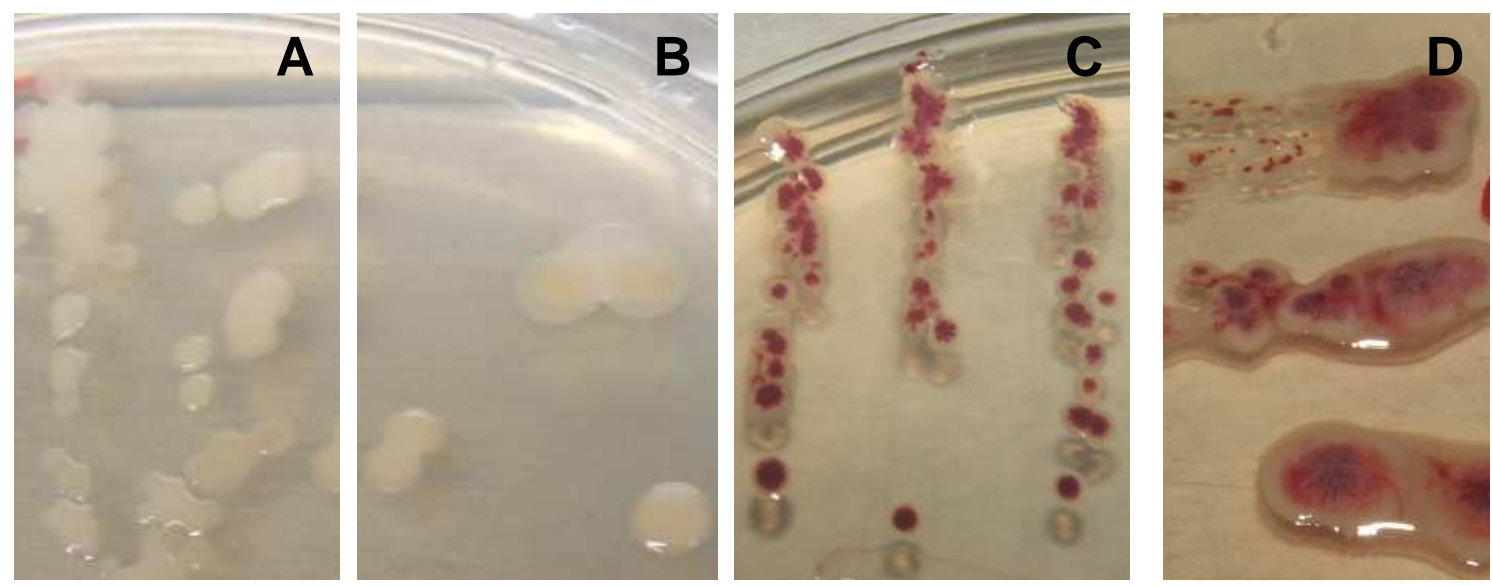

Figura 25. Aspecto de las colonias de $R$. solanacearum observadas en YDA (A y B) y en TTC (C y D). 
A partir de las placas madre iniciales, las colonias se repicaron semanalmente en medio TTC, comprobando su nivel de patogenicidad mediante inoculación en hojas de tabaco como ya sugirieran Lozano y Sequeira (1970) y, se empleó la técnica PCR con posterior secuenciación de la cepa empleada (GenBank Accession No. FJ007371) para su previa identificación como R. solanacearum al inicio del bioensayo.

Respecto al resultado de la inoculación en los espacios internerviales de hojas de tabaco, al igual que ocurría en el caso de C.m.michiganensis, en función de las condiciones de invernadero donde se desarrolló el ensayo, la respuesta hipersensible del huésped ya se observaba transcurridas las primeras $24 \mathrm{~h}$ desde su infiltración. La evolución de la inoculación se observa en la figura 26.

De acuerdo con la información aportada por Lozano y Sequeira (1970), la reacción de hipersensibilidad observada dependerá de las condiciones de trabajo

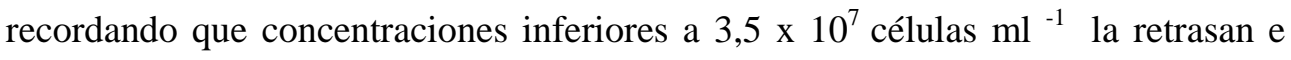
incluso no la inducen, de este modo también con esta bacteria se emplearon siempre concentraciones no inferiores a $10^{8} \mathrm{UFC} \mathrm{ml}^{-1}$. 

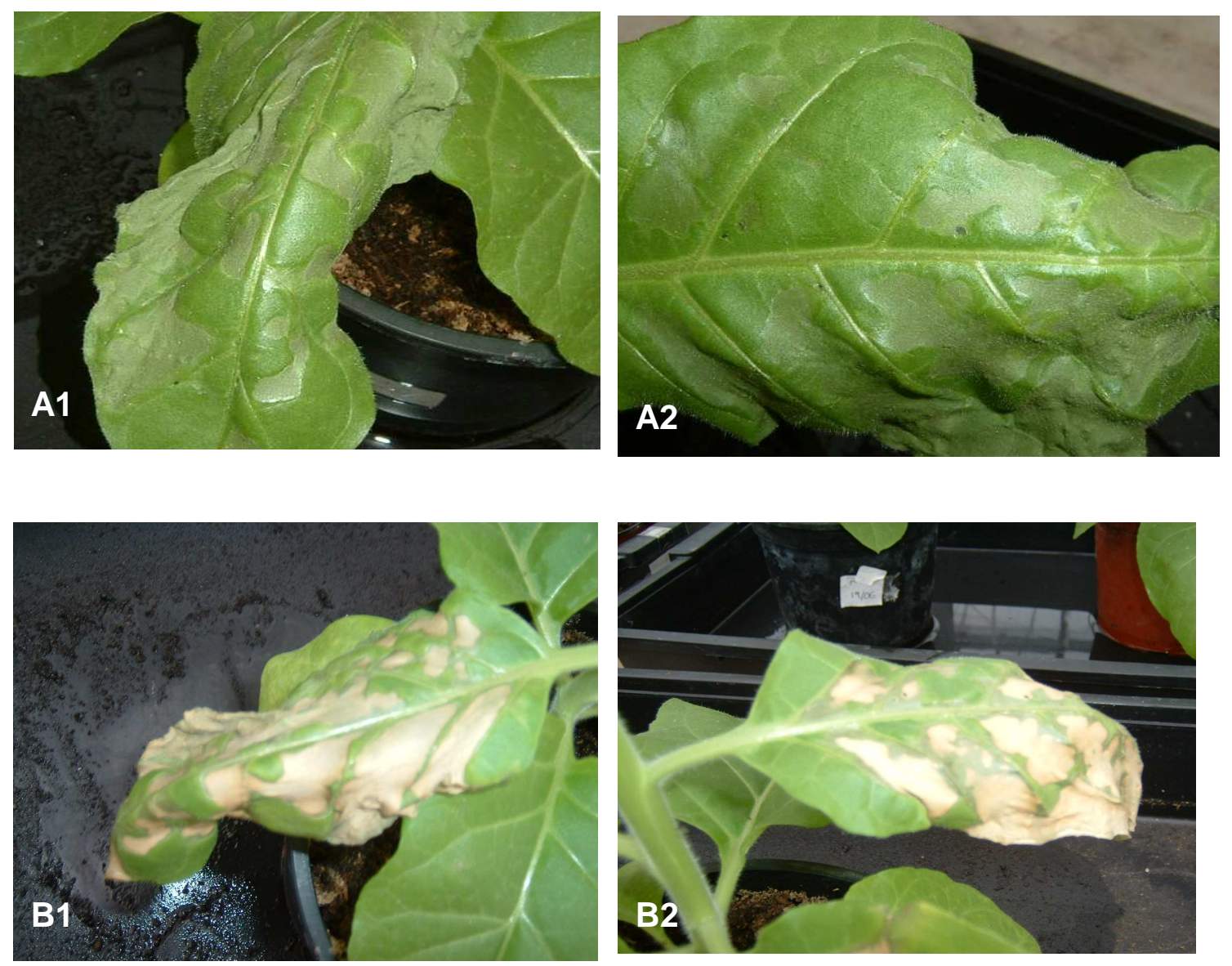

Figura 26. Avance de la respuesta hipersensible de $R$. solanacearum en plantas de tabaco, en las condiciones de ensayo en invernadero. A: avance de síntomas transcurrido 1 día desde la inoculación. B: estado de la zona infiltrada transcurridos 4 días desde la inoculación

\subsection{Inoculación artificial en plantas de tomate: sintomatología asociada}

La inoculación artificial de las soluciones bacterianas en las axilas de hojas de tomate provocaba síntomas característicos apreciándose principalmente en el tallo, coincidentes con los descritos en asociación con la bacteria debido a su capacidad de invadir los vasos conductores. 
Estos síntomas se pueden observar en la figura 27, de modo que proliferan los abultamientos en tallo y amarilleos de hojas completas. Si se realiza un corte transversal de las zonas severamente dañadas, se detecta el avance del oscurecimiento de la zona interior, quedando invadida por las colonias bacterianas y que implicará el marchitamiento total de la planta de tomate, transformándose en fuente potencial de infección.

Conviene recordar la producción masiva de EPS por parte de la bacteria y que son los responsables de los síntomas asociados como recogen Kang et al. (1999) y, por tanto, se relacionan con el avance de la infección sistémica.

De acuerdo con otros autores (Caruso, 2005), la entrada de las bacterias en las plantas ocurre a través de heridas, y en caso de realizarse desde la zona aérea, avanzan hasta alcanzar el sistema radicular, de ahí la forma de inoculación seleccionada para la obtención de material vegetal infectivo. Como indican TimmsWilson et al. (2001) y Rahman et al. (1999), una vez en el interior, y alcanzado el xilema, se expanden por toda la planta convirtiéndose toda ella en un importante foco de infección.

Los síntomas descritos coinciden con los recogidos por la OEPP/EPPO (2004a), especialmente en lo que respecta a los vasos conductores, con su coloración parda y exudado mucoso. Además, en condiciones favorables para el patógeno, el marchitamiento de las plantas ocurre rápidamente, en este caso y en las condiciones de trabajo, se detectaba trascurridos 15 días desde la inoculación en las axilas de las hojas llamando la atención la aparición de protuberancias en el tallo que, de acuerdo con la OEPP, se identificarían como raíces adventicias. 


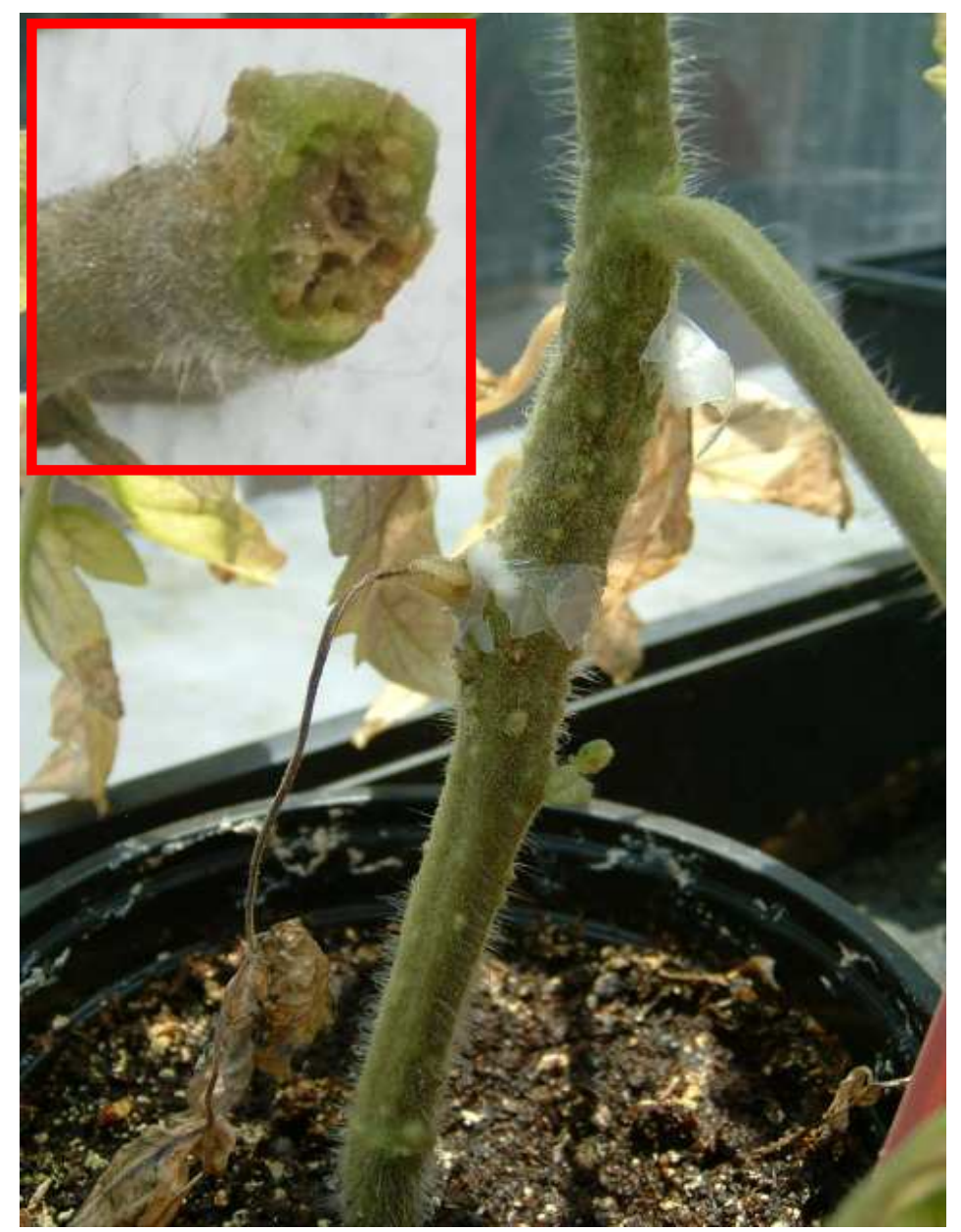

Figura 27. Plantas de tomate con síntomas observados tras la inoculación de $R$. solanacearum

\subsection{Microscopía electrónica de barrido de tallos de tomate inoculados} artificialmente

También se han observado empleando el microscopio electrónico de barrido las interacciones ultraestructurales entre la bacteria $R$. solanacearum y los tejidos vegetales afectados tras la introducción de la bacteria en las plantas de tomate (figura 28). 

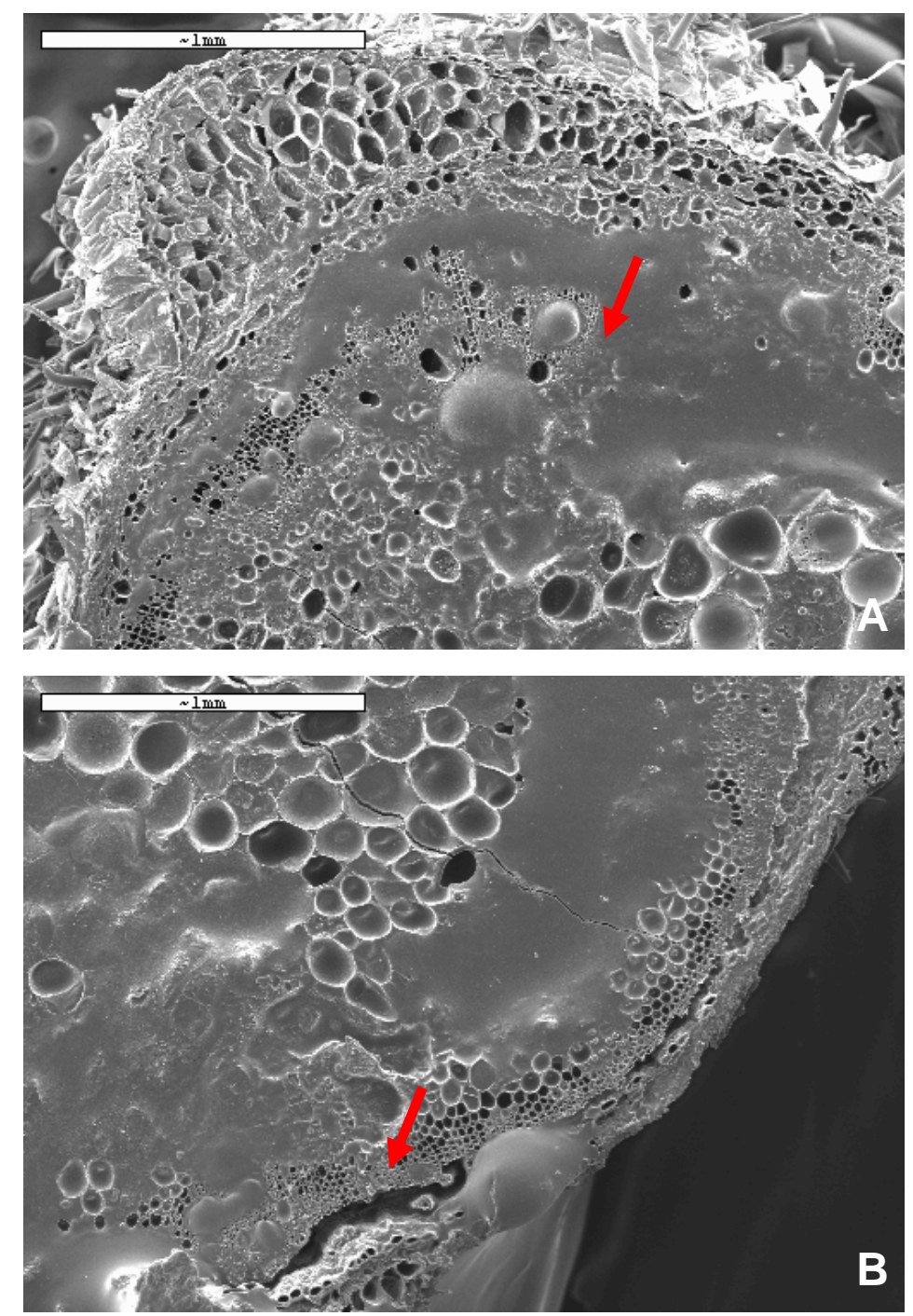

Figura 28. Imágenes observadas por microscopía electrónica de barrido de una sección transversal de un tallo infectado de tomate inoculado con $R$. solanacearum. A: se observan vasos obstruidos $\mathrm{B}$ : se observan vasos obstruidos y desprendimiento de tejido en la parte inferior derecha debido a la degradación de los tejidos. 
De nuevo se observa claramente la aparición de exudados bacterianos, relacionándose con los exudados mucosos descritos por la EPPO/OEPP (2004 a) y los daños a nivel interno debido a la degradación del material por parte del avance de la bacteria y por la producción de EPS. Además, este estudio permite observar la formación de las raíces adventicias iniciadas como protuberancias que van avanzando hasta su pleno desarrollo.

Una vez conocido el comportamiento de la bacteria en las condiciones de ensayo, respecto la invasión de plantas huéspedes seleccionadas y una vez descrita sintomatología asociada a la cepa en estudio, se puede proceder con la técnica de bioensayo diseñada para intentar el control de la infección provocada por $R$. solanacearum.

\subsection{Diseño de la experiencia de biofumigación y biosolarización en condiciones de invernadero}

\subsubsection{Tratamiento de biofumigación en macetas: $25^{\circ} \mathrm{C}$}

Los resultados obtenidos corresponden a la metodología expuesta en el apartado 1.5.1.al igual que se hizo con la bacteria C.m.michiganensis. De nuevo se obtuvieron los resultados al tratamiento térmico de macetas con y sin enmiendas vegetales y tras su introducción o no en bolsas de plástico herméticas.

$\mathrm{Al}$ igual que se ha expuesto en el apartado 1.4.1. de este capítulo, en los lotes, la mitad de las macetas preparadas incorporando material vegetal sano se consideraron como controles, al igual que 8 macetas por lote conteniendo únicamente substrato, controlando posibles contaminaciones y observando comportamientos anormales, especialmente el efecto en crecimiento y desarrollo de vigor dependiendo de las condiciones de invernadero y sus modificaciones. Pero en este caso no se detectaron importantes diferencias entre las plantas de tomate sanas que crecieron sobre material vegetal infectado respecto a las que lo hicieron sobre material vegetal sano o incluso sobre substrato sin adición de material vegetal. 
Tras los tratamientos a $25^{\circ} \mathrm{C}$, los porcentajes de plantas que mostraron resultado positivo a la presencia de $R$. solanacearum tras ser analizadas por la técnica serológica DAS-ELISA (transcurridos 40 días tras su trasplante) se recogen en la tabla 18, recordando que el porcentaje de infección alcanzado para la "semana 0" corresponde con el máximo nivel de infección alcanzado sin ningún tipo de tratamiento y que sirve como dato de partida. Esto significa que cualquier reducción de la infección que se obtenga se considerará como un efecto positivo de los tratamientos ensayados.

Tabla 18. Incidencia de la enfermedad, expresada en porcentaje de plantas mostrando resultado positivo por DAS-ELISA a la presencia de $R$. solanacearum tras las semanas de tratamiento a $25^{\circ} \mathrm{C}$

\begin{tabular}{ccc}
\hline \multicolumn{3}{c}{$\begin{array}{c}\text { Incidencia de la enfermedad } \mathbf{2 5}^{\mathbf{}} \mathbf{C}(\%) \\
\text { tipo de } \text { macetas }^{\mathbf{a}}\end{array}$} \\
Semana & NB & B \\
\hline $\mathbf{0}^{\mathbf{b}}$ & 41,6 & 33,3 \\
$\mathbf{1}$ & 16,6 & 16,6 \\
$\mathbf{2}$ & 16,6 & 16,6 \\
$\mathbf{3}$ & 0 & 0 \\
$\mathbf{4}$ & 0 & 0 \\
$\mathbf{5}$ & 8,3 & 0 \\
$\mathbf{6}$ & 0 & 33,3 \\
\hline
\end{tabular}

${ }^{a} \mathrm{NB}$ : macetas no encerradas en bolsas de plástico; B: macetas encerradas herméticamente en bolsas de plástico

${ }^{\text {b }}$ Semana 0 sin tratamiento térmico: máximo nivel de infección de partida

Los resultados expuestos en la tabla 18, muestran el efecto observado en un total de 24 macetas para cada uno de los lotes ( 3 dosis de material vegetal con 2 tipos de macetas y con 4 repeticiones). 
Se observa que en el caso de las macetas que permanecieron abiertas se detecta la presencia de bacterias que continúan siendo infectivas transcurridas 5 semanas de tratamiento a $25^{\circ} \mathrm{C}$, pero el resultado más interesante se observa en el caso de las macetas que permanecieron encerradas en bolsas, ya que tras las 6 semanas de tratamiento continúan siendo altamente infectivas, igualando el nivel de infección de la semana 0 o sin tratamiento, deduciéndose que, en las condiciones de ensayo, el tratamiento a $25{ }^{\circ} \mathrm{C}$ no ha tenido efecto en el control de R. solanacearum.

Las diferencias específicas de los tratamientos entre las macetas abiertas o cerradas considerando las dosis ensayadas de material vegetal infectado introducido en las mismas, se recogen en la figura 29 , representando las medias de cuatro repeticiones por tratamiento, mostrándose los análisis estadísticos a continuación.

Los análisis de varianza para la incidencia de la enfermedad sólo mostraron diferencias significativas entre las semanas de tratamiento con $\mathrm{P}<0,05$ (tabla 19).

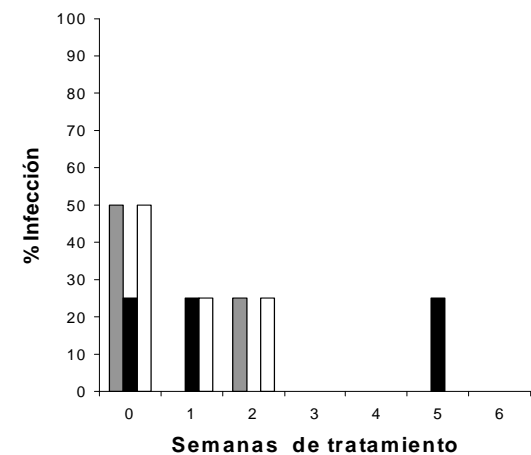

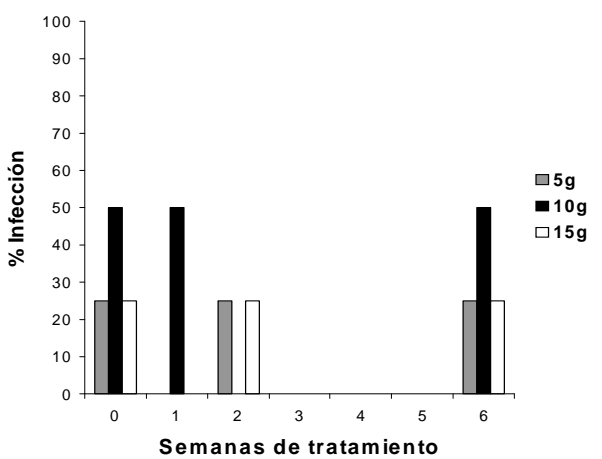

Figura 29. Efecto de los tratamientos a $25^{\circ} \mathrm{C}$ en la incidencia final de la enfermedad, expresada como porcentaje de plantas de tomate infectadas por $R$. solanacearum en macetas sin bolsa (NB) y en macetas encerradas en bolsas de plástico (B) a los 40 días del trasplante. Los histogramas representan el porcentaje 
de infección obtenido en cuatro repeticiones por tratamiento y dosis de material vegetal infectado e incorporado

Tabla 19. Resultados obtenidos del análisis de la varianza de los valores medios de la incidencia de la enfermedad para los factores dosis de material infectado, semanas de duración del tratamiento térmico y tipo de macetas (abiertas o cerradas), así como para sus interacciones, para los tratamientos a $25^{\circ} \mathrm{C}$ contra $R$. solanacearum.

\begin{tabular}{ccc}
\hline Efectos & G.L. & Valores de $\mathbf{P}^{\mathbf{a}}$ \\
\hline dosis & 2 & 0,455 \\
semanas & 6 & 0,000 \\
macetas & 1 & 0,501 \\
\hline Interacciones & & \\
\hline dosis*semanas & 12 & 0,190 \\
dosis*macetas & 2 & 0,249 \\
semanas*macetas & 6 & 0,088
\end{tabular}

${ }^{\text {a }}$ Valores de $\mathrm{P}<0,05$ implican diferencias significativas

En la tabla 20 se recoge el resultado obtenido mediante el test LSD de Fisher $(\mathrm{P}<0,05)$ para los distintos factores considerados.

Respecto a los resultados cabe destacar lo observado con las semanas de tratamiento, puesto que aunque la infección continúe tras la sexta y última, el nivel de infección difiere significativamente respecto a la semana 0 , por lo que sí que funcionaría el tratamiento si lo que se persiguiera fuera una disminución de la infección, pero a nivel práctico y considerando de nuevo que se maneja una bacteria de cuarentena, el que la enfermedad causada por $R$. solanacearum pueda transmitirse a través del suelo, y en asociación con restos de cultivo, es un riesgo potencial. La no detección de la bacteria tras las semanas 3 y 4 pierde todo su significado al reaparecer tras las semanas posteriores de tratamiento, lo que no deja de catalogar estos resultados como de arriesgados, puesto que si no se hubiese 
continuado hasta la sexta semana de tratamientos térmicos la no detección habría resultado engañosa. Todo ello también justifica el acierto de la ampliación del estudio con los posteriores apartados respecto a la asociación y supervivencia de la bacteria tanto en restos vegetales como en substratos, hecho que habría evitado resultados erróneos.

Este resultado de no detección tras las semanas 3 y 4 puede relacionarse con diversos factores considerando desde las condiciones ambientales en el momento de los muestreos o incluso que tras el trasplante y crecimiento de las plántulas el sistema radicular nunca entrase en contacto con las bacterias asociadas a los restos de tomate introducidos.

Tabla 20. Resultados obtenidos mediante la realización de la prueba de Fisher (LSD con $\mathrm{P}<0,05)$ para los diferentes factores considerados en los tratamientos a $25^{\circ} \mathrm{C}$ : dosis, tipo de macetas $(\mathrm{NB}=\sin$ bolsa, $\mathrm{B}=$ con bolsa) y semanas de tratamiento, transcurridos 40 días tras el trasplante. Las medias representan la incidencia de la enfermedad según el porcentaje de plantas afectadas por R. solanacearum.

\begin{tabular}{cccccccc} 
Temp. & Macetas & LS media & Dosis (g) & LS media & Semana & LS media \\
\hline $\mathbf{2 5}^{\circ} \mathbf{C}$ & NB $^{\mathrm{x}}$ & $11.90 \mathrm{a}^{\mathrm{y}}$ & $5^{\mathrm{x}}$ & $10.71 \mathrm{a}$ & 3 & 0 & $\mathrm{a}$ \\
& $\mathrm{B}$ & $14.28 \mathrm{a}$ & 15 & $12.50 \mathrm{a}$ & 4 & 0 & $\mathrm{a}$ \\
& & 10 & $16.07 \mathrm{a}$ & 5 & $4.16 \mathrm{ab}$ \\
& & & & 1 & $16.66 \mathrm{~b}$ \\
& & & & 2 & $16.66 \mathrm{~b}$ \\
& & & & & 6 & $16.66 \mathrm{~b}$ \\
& & & & 0 & $37.50 \mathrm{c}$ \\
\hline
\end{tabular}

${ }^{\mathrm{x}}$ Cuatro repeticiones por dosis y tratamiento

${ }^{\mathbf{Y}}$ Los valores de cada columna seguidos por la misma letra no difieren significativamente de acuerdo con el método LSD

${ }^{\mathrm{Z}}$ Incidencia de la infección expresada como porcentaje de plantas afectadas por la bacteria trasnscurridos 40 días tras el trasplante empleando la técnica DAS-ELISA 180 
En función de los resultados obtenidos cabe recordar que, de acuerdo con diversos autores (Caruso, 2005; Hayward, 1991), la temperatura es el principal factor que afecta a la interacción entre huésped y patógeno además de influenciar en la supervivencia de la bacteria en el suelo, situándose la temperatura óptima de infección cercana a los $30^{\circ} \mathrm{C}$. El no haber obtenido efectos en el control de la enfermedad, tras aplicar la técnica expuesta, estaría directamente relacionado con esta circunstancia, además de considerar que las macetas se riegan hasta alcanzar la capacidad de campo previamente a su introducción en las cámaras térmicas, donde se someten a los tratamientos. El hecho mantener la mitad de las macetas encerradas en bolsas de plástico de forma hermética favorece que se mantengan elevadas humedades que junto a las temperatura de $25{ }^{\circ} \mathrm{C}$, cercana al óptimo de desarrollo bacteriano, como indican en sus investigaciones Momol et al. (2003), favorece la proliferación y supervivencia bacteriana en el substrato favoreciendo la incidencia y severidad de la enfermedad causada por $R$. solanacearum.

Pese a la diferencia de los niveles de infección detectados y pese a haber encontrado la causa relacionada con estos efectos, estadísticamente no existen diferencias entre macetas encerradas o abiertas, recobrando de nuevo importancia el factor térmico.

Sólo quedaría pendiente recordar que los resultados de detección bacteriana en plantas se han realizado mediante la técnica ELISA, que no facilita información acerca del nivel de patogenicidad sino que sólo confirma la presencia del patógeno. Considerando la naturaleza expuesta de $R$. solanacearum se exponen nuevas hipótesis ya que quizás se está detectando $R$. solanacearum no patógena o en estado VBNC (viable pero no cultivable).

\subsubsection{Tratamiento de biosolarización en macetas: $45^{\circ} \mathrm{C}$}

En la figura 30 se recogen los porcentajes de plantas con resultado positivo a la presencia de $R$. solanacearum: no se detecta en ninguna de las plantas 
trasplantadas independientemente del tipo de macetas, de las dosis ensayadas y de las semanas de tratamiento, por lo que un tratamiento de $45^{\circ} \mathrm{C}$ resultaría efectivo en el control de la enfermedad de marchitamiento bacteriano asociado a $R$. solanacearum.

NB

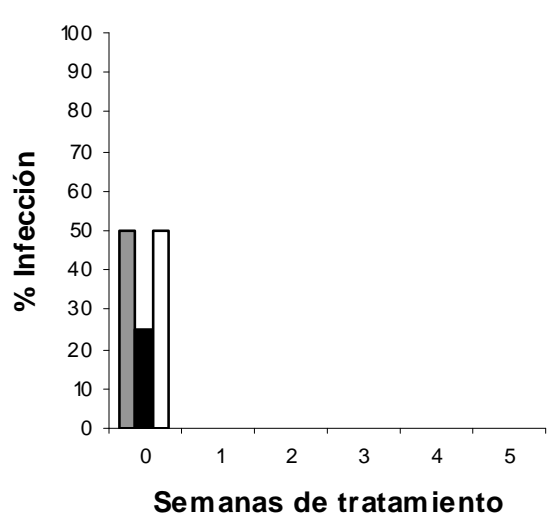

B

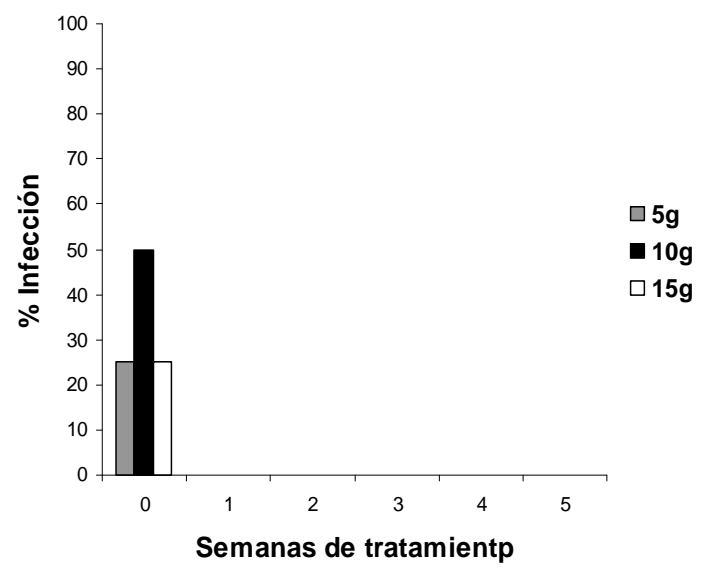

Figura 30. Efecto de los tratamientos a $45^{\circ} \mathrm{C}$ en la incidencia final de la enfermedad, expresada como porcentaje de plantas de tomate infectadas por $R$. solanacearum en macetas encerradas en bolsas de plástico (B) y en macetas sin bolsa (NB) a los 40 días del trasplante. Los histogramas representan el porcentaje de infección obtenido en cuatro repeticiones por tratamiento y dosis de material vegetal infectado e incorporado

En función de los resultados obtenidos, el afirmar que la bacteria ha sido eliminada, tras los tratamientos a $45{ }^{\circ} \mathrm{C}$, supone un riesgo debido a determinadas características bacterianas que hay que tener en cuenta. De nuevo resultaría prudente considerar esta eliminación como la no detección e la bacteria en función de las técnicas de diagnóstico empleadas, dentro de sus límites de sensibilidad. 
Volviendo a considerar la temperatura como el factor de mayor importancia en la interacción huésped-patógeno y en la supervivencia en suelos y substratos, el resultado concordaría con los obtenidos por Haward (1991), ya que para este autor aquellos suelos sometidos a $43{ }^{\circ} \mathrm{C}$ durante sólo 4 días, aparecen libres de la presencia de $R$. solanacearum.

A los efectos ejercidos por las temperaturas superiores a $43{ }^{\circ} \mathrm{C}$, hay que añadir los efectos beneficiosos en la disminución de la población bacteriana relacionada con la adición de enmiendas al substrato, como ya observaron Davi et al. (1981) e Islam y Toyota (2004).

Los efectos reflejados en los resultados corroboran también los obtenidos por Schönfeld et al. (2003) y por Gorissen et al. (2004) que combinan la adición de enmiendas orgánicas con solarización, obteniendo los mejores resultados en la reducción de la población bacteriana de $R$. solanacearum. Pero estos últimos autores ya indicaron que, en ocasiones, plantas aparentemente sanas en suelos tratados mostraron la presencia de la bacteria pero en forma latente. Precisamente, esta es una de las cualidades de la bacteria en estudio a considerar ya que, en condiciones adversas puede entrar en estado de latencia sin olvidar la posible conversión fenotípica indicada por Caruso (2005) que permite a la bacteria asegurarse la supervivencia en diferentes condiciones ambientales. A todo ello hay que adicionar el estado VBNC que también permite a $R$. solanacearum sobrevivir a situaciones ambientales críticas, que incluyen las condiciones de suelos estériles.

En función de todo ello habrá que incidir en que los resultados expuestos en este trabajo se han obtenido en condiciones controladas, añadiendo datos específicos a todos los efectos observados por el resto de autores en distintas condiciones acerca del comportamiento de $R$. solanacearum, para favorecer el control de una posible infección en campo. 


\subsection{Introducción y recuperación de $\boldsymbol{R}$. solanacearum en substratos infectados}

artificialmente

Tras los tratamientos a $25{ }^{\circ} \mathrm{C}$ (tabla 21), se detectan altos niveles poblacionales de $R$. solanacearum en los dos medios de cultivo ensayados, general y específico. Los cultivos puros, identificados mediante la técnica serológica DASELISA y sus soluciones inoculadas en hojas de tabaco siempre dieron reacciones de patogenicidad positivas, por lo que se deduce que en condiciones térmicas favorables de $25^{\circ} \mathrm{C}$, las células de $R$. solanacearum introducidas en el substrato como células libres, permanecen infectivas, resultado que también soluciona el interrogante que quedaba pendiente en el apartado 2.4.1.: las bacterias presentes y detectadas por ELISA se pueden cultivar y, además, son supuestamente patógenas por dar reacción de hipersensibilidad en tabaco. Con todo ello ya se puede confirmar que el tratamiento a $25^{\circ} \mathrm{C}$ no resultó eficaz en el control de $R$. solanacearum.

Tras los tratamientos a $45{ }^{\circ} \mathrm{C}$ nunca se detectaron colonias de $R$. solanacearum en las placas de cultivo.

Observando la figura 31, las poblaciones de otras colonias observadas se mantienen casi constantes tras los tratamientos térmicos

Tabla 21. Promedio del conteo de colonias de $R$. solanacearum en el substrato tras un periodo de 6 semanas a $25^{\circ} \mathrm{C}$

\begin{tabular}{cccccccc} 
Medio nutritivo & \multicolumn{1}{l}{$\mathbf{L o g ~ c f u ~}^{-1}$ substrato $^{\text {a }}$} \\
\hline & \multicolumn{1}{l}{ Sem. tratam. $\mathbf{~}^{2{ }^{\circ} \mathrm{C}}$} \\
\cline { 2 - 8 } & 0 & 1 & 2 & 3 & 4 & 5 & 6 \\
\hline YDA & 5,544 & 5,506 & 5,739 & 4,453 & 3,534 & 3,926 & 4,396 \\
TTC & 5,539 & 5,444 & 5,623 & 4,609 & 4,72 & 4 & 3,634 \\
\hline
\end{tabular}

${ }^{\text {a }}$ Promedio del conteo de ufc $\mathrm{g}^{-1}$ de substrato en placas Petri a partir del método de las diluciones seriadas, con 5 diluciones y 2 repeticiones por medio nutritivo ensayado $(5 \times 2 \times 2)$ 

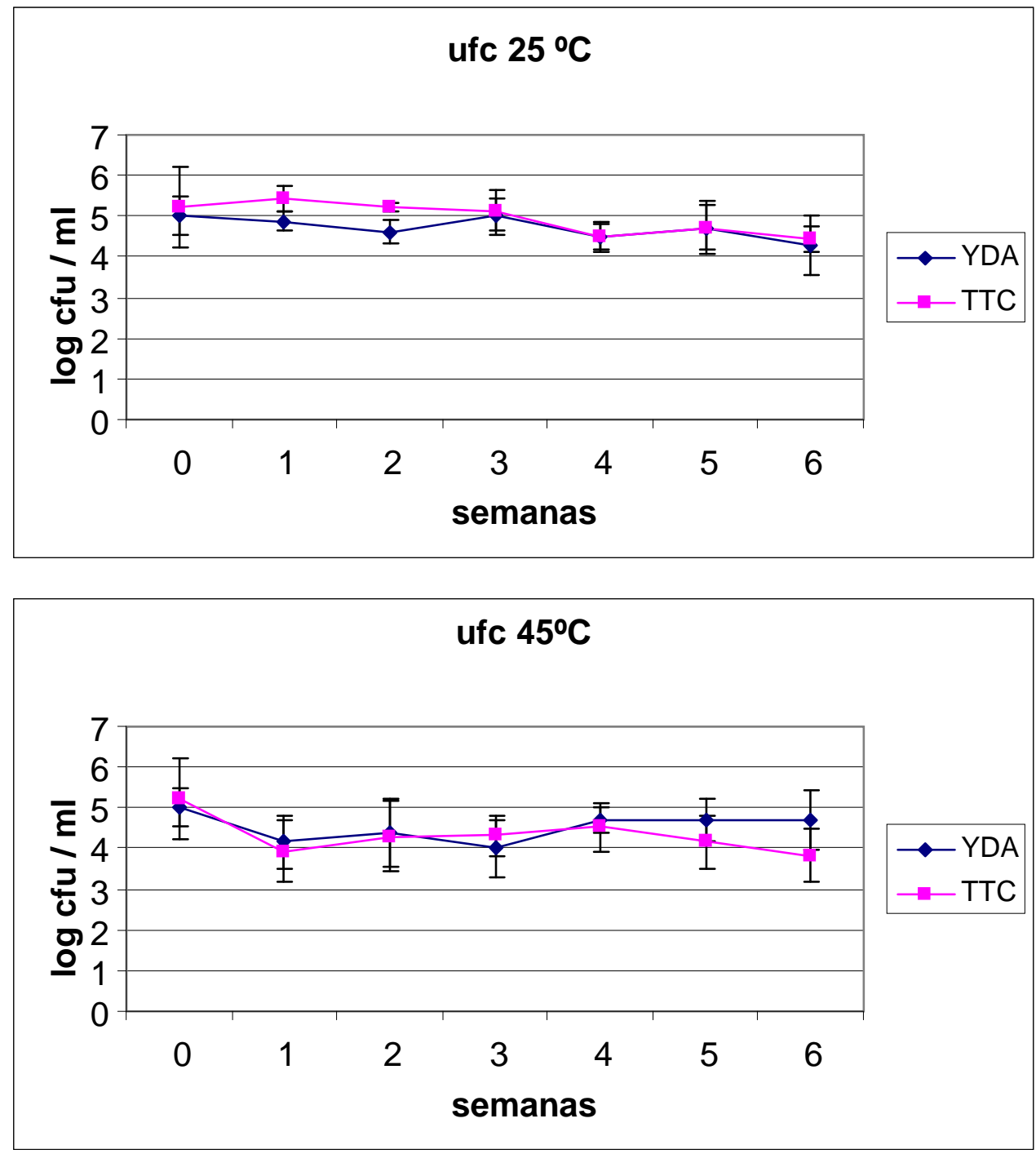

Figura 31. Crecimiento de colonias bacterianas diferentes a $R$. solanacearum en los medios de crecimiento tras los tratamientos térmicos a $25^{\circ} \mathrm{C}$ y $45^{\circ} \mathrm{C}$

Los resultados de supervivencia de $R$. solanacearum en substratos, tras las semanas de tratamiento a $25{ }^{\circ} \mathrm{C}$, concuerdan nuevamente con los expuestos por Caruso (2005) respecto a que la bacteria es capaz de sobrevivir durante largos 
periodos de tiempo, incluso en ausencia de plantas hospedadoras y con condiciones ambientales favorables. En este caso, se ha comprobado su presencia hasta la sexta semana pero, atendiendo a otros autores, como McCarter (1976), puede llegar a persistir hasta 4 años en aquellos suelos infectados de forma artificial.

Teniendo en cuenta los resultados negativos de detección bacteriana tras los tratamientos a $45{ }^{\circ} \mathrm{C}$, de nuevo hay que considerar la importancia de la temperatura en el control de la enfermedad transmitida por $R$. solanacearum a través del suelo, por lo que se puede concluir que el tratamiento de suelos y substratos a temperaturas cercanas a $45{ }^{\circ} \mathrm{C}$, siempre y cuando superen los $43{ }^{\circ} \mathrm{C}$, resulta efectivo para minimizar riesgos de transmisión.

En la detección de las colonias bacterianas, se ha empleado el método más antiguo y efectivo de aislamientos como indican numerosos autores (Chen y Echandi, 1982; Karganilla y Buddenhagen, 1972; Nesmith y Jenkins, 1979) pero, también se pueden obtener resultados negativos por inhibición del crecimiento del patógeno debido a la presencia de otras bacterias en el medio, en este caso, en el substrato. Por ello se han realizado otros estudios, especialmente de la evolución de distintas colonias bacterianas observadas y diferentes a $R$. solanacearum tras los tratamientos térmicos que se recogen en las figuras 31 y 32 . Respecto a la evolución del número de colonias, este permanece casi constante tras las semanas de tratamiento a 25 y $45^{\circ} \mathrm{C}$.

Las colonias de $R$. solanacearum se enfrentaron a las colonias bacterianas con actividad de antibiosis que tuvieron efecto ante C.m.michiganensis, pero en este caso no se observó actividad frente a B. subtilis.

En la figura 32 se observa la tendencia del efecto de los tratamientos térmicos en la dinámica poblacional de $R$. solanacearum y de otras colonias evaluadas a $25^{\circ} \mathrm{C}$. En función de los medios nutritivos, las mayores poblaciones se obtienen para la bacteria en el medio selectivo y para el resto en medio general, aunque tras las 6 semanas de tratamiento todas las colonias se mantienen a elevados niveles. Considerando que durante los tratamientos a $25^{\circ} \mathrm{C}$, el campo 
habría de permanecer libre, superadas las 6 semanas correspondientes a un mes y medio ya no resulta viable, pues los agricultores necesitan prácticas de desinfección efectivas y rápidas, que puedan competir con otras técnicas de desinfección, especialmente, con los tratamientos químicos.

\section{Dinámica poblacional $25 \stackrel{\circ}{ } \mathrm{C}$}

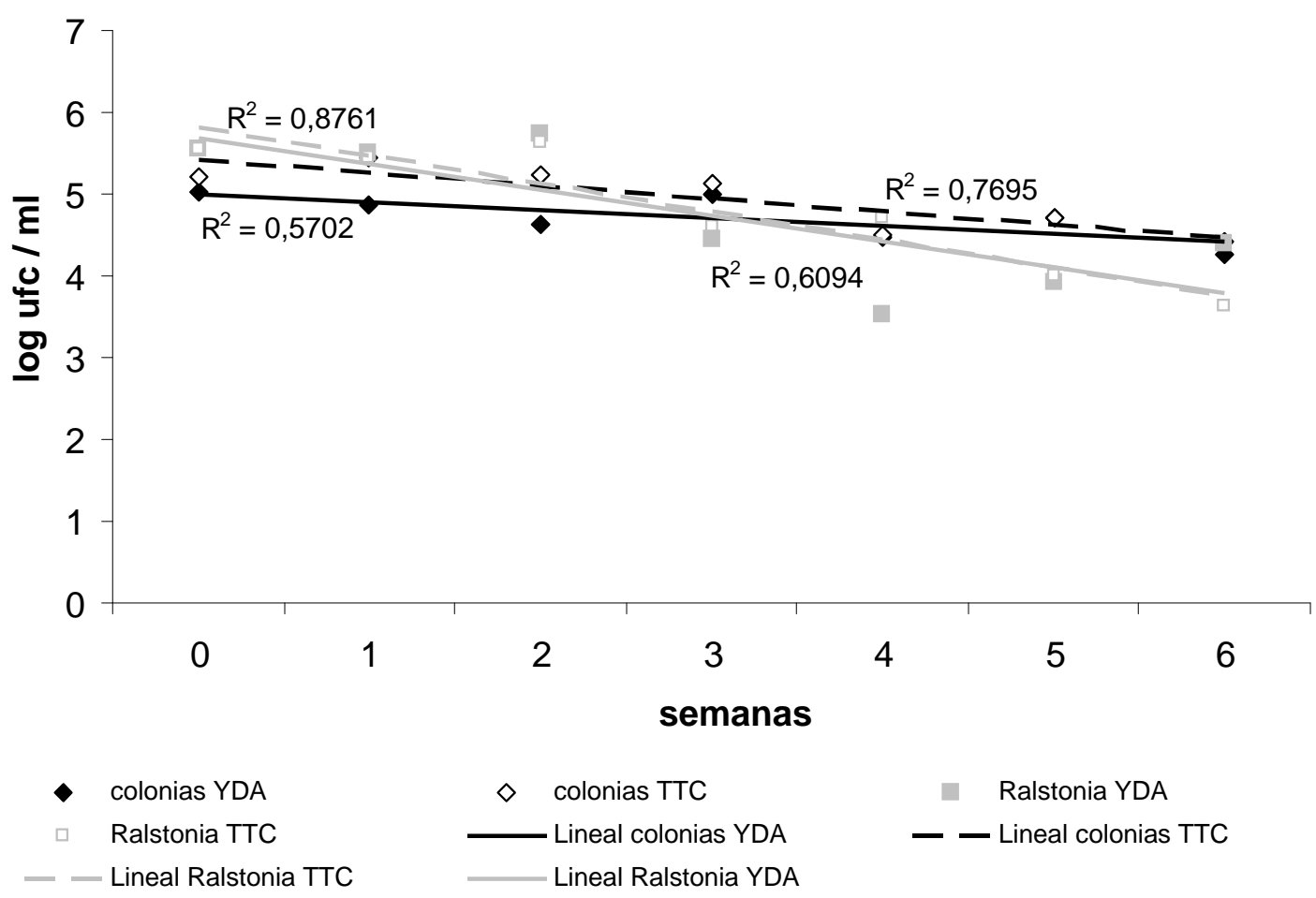

Figura 32. Efecto del tratamiento térmico a $25{ }^{\circ} \mathrm{C}$ en la dinámica poblacional de $R$. solanacearum y del resto de colonias de bacterias observadas en los medios nutritivos ensayados (YDA y TTC). 
2.6. Determinación de la supervivencia de $R$. solanacearum en asociación con tejidos vegetales

Las suspensiones que se obtenían directamente a partir del material vegetal recuperado y extraído del substrato tratado a $25{ }^{\circ} \mathrm{C}$, dieron resultado positivo, mediante ELISA, hasta la sexta semana de tratamiento, al igual que tras los tratamientos a $45^{\circ} \mathrm{C}$, en cambio, las soluciones inoculadas en tabaco procedentes de los restos vegetales infectados, enterrados y recuperados nunca dieron resultado positivo tras inocularlas en hojas de tabaco.

Respecto a los restos vegetales sin substrato, a $25^{\circ} \mathrm{C}$, el ELISA reveló resultados positivos hasta la sexta semana de tratamiento, al igual que se observó tras las semanas a $45{ }^{\circ} \mathrm{C}$. Pero de nuevo, las soluciones inoculadas en tabaco procedentes de los restos vegetales recuperados nunca dieron resultado positivo tras inocularlas en hojas de tabaco.

En las dos experiencias descritas, el hecho de obtener resultados positivos aplicando la técnica ELISA, no es de extrañar, puesto que detecta la presencia de células bacterianas, activas o muertas, y hay que recordar que los restos vegetales empleados presentaban un elevadísimo nivel de infección. El resultado interesante se plantea al considerar una posible pérdida en la virulencia bacteriana debido a la asociación con los restos de tomate, lo que apoyaría los efectos obtenidos por Pradhanang (2003) y por Ji et al. (2005) respecto a la actividad de determinados compuestos volátiles como el Thymol, presente en los restos de tomate como indican Kim y Kil (2001) abriendo la posibilidad de actuación antibacteriana del restos de compuestos liberados e identificados en el estudio de estos últimos autores o por Ríos et al. (2008), Yu (1999) y Abdel-Mallek et al. (1995).

Como conclusiones, en asociación con material vegetal la bacteria siempre se detecta, pero el hecho de no resultar patógena tras su inoculación en tabaco, puede relacionarse con que la técnica serológica ELISA es capaz de reconocer la presencia del patógeno, aunque este no esté activo. Por otra parte, la bacteria se detecta siempre tras los tratamientos a $25{ }^{\circ} \mathrm{C}$ en el substrato, por lo que el 
tratamiento térmico no le afecta. El hecho de no detectarse a $45{ }^{\circ} \mathrm{C}$ puede deberse a que su incorporación se realiza de forma directa, como células libres, e inmediatamente se trata térmicamente, por lo que al someter las placas de cristal a $45^{\circ} \mathrm{C}$ la bacteria puede no resistir y no colonizar el substrato.

En función de lo expuesto, se explicarían los resultados observados en el bioensayo en macetas, de modo que la bacteria no se detecta a $45^{\circ} \mathrm{C}$ ya que a esta temperatura no coloniza el substrato y en asociación con el material vegetal puede no ser patogenicamente activa. Por otra parte, a $25^{\circ} \mathrm{C}$ nunca se controla, pudiendo pasar al substrato e infectándolo o, incluso, mantenerse asociada al material vegetal.

Para finalizar, no hay que olvidar que esta bacteria tiene un estado VBNC así como una posible conversión fenotípica, que le permite permanecer en estado de latencia hasta entrar de nuevo con material vegetal y volverse patógena de nuevo. Se podría considerar como "un estado de resistencia" que permite a $R$. solanacearum permanecer asociada a substratos infectando cultivos posteriores.

\section{Biofumigación y biosolarización en el control de bacterias fitopatógenas: discusión general}

Los resultados obtenidos en este trabajo ponen de manifiesto el efecto que puede ejercer la combinación de las técnicas de solarización y biofumigación en el control de las enfermedades bacterianas transmitidas por las bacterias ensayadas: C.m.michiganensis y $R$. solanacearum.

A partir del bioensayo en macetas se demuestra el efecto de las temperaturas, superiores a $40{ }^{\circ} \mathrm{C}$, en la erradicación de las bacterias patógenas asociadas al substrato, especialmente en el caso de $R$. solanacearum, corroborando los resultados de Pullman et al. (1981a; 1981b). En este caso conviene señalar que se ha utilizado la combinación de los métodos de detección aconsejados por Noble y Roberts (2004) y Graham y Lloyd (1978), autores que emplean, respectivamente, la técnica serológica ELISA al ser la técnica más comúnmente empleada para la 
detección de patógenos en suelos y composts, mientras que los segundos apoyan el empleo de plantas sanas de tomate como trampa biológica que detectan fácilmente la presencia de las bacterias patógenas capaces de invadir las plantas por contacto directo con el sistema radicular, proporcionando además una información sobre su capacidad de instalación y multiplicación en la planta..

Las infecciones asociadas al inóculo bacteriano que es capaz de sobrevivir en suelos y substratos, libremente o en asociación con restos de cultivo, resultan problemáticas, causando la aparición de síntomas severos que son responsables de importantes pérdidas en el rendimiento. A partir de los resultados obtenidos, también se demuestra la importancia del inóculo con alta capacidad infectiva y que lo convierte en focos de infección, habiendo comprobado la transmisión de enfermedades bacterianas a partir de restos de cultivo como indican numerosos autores (McCarter, 1976; Gram. y Lloyd, 1979; Leben, 1981; Nesmith y Jenkins, 1983; Noble y Roberts, 2004; Ji et al., 2005) y que se demuestra a partir de los altos niveles de infección alcanzados en las plantas que crecieron sobre macetas enmendadas con restos de cultivo altamente infectivos que no se sometieron a ningún tipo de tratamiento (correspondientes a las semanas 0).

Considerando los niveles de infección anteriormente referidos, respecto a la presencia de patógenos en los substratos en asociación con material vegetal, sí que se observan efectos positivos tras los tratamientos a $25^{\circ} \mathrm{C}$, para las distintas dosis de restos adicionados, técnica considerada como biofumigación. Estos efectos supondrán una disminución en el nivel de infección de la enfermedad bacteriana en las plántulas crecidas sobre substratos tratados, pero, al manejar bacterias de cuarentena, no se pueden considerar como resultados favorables, puesto que una disminución no implica la erradicación del patógeno, con el riesgo potencial que supondrá la presencia bacteriana en campo. Aún así, si que se obtiene información interesante acerca del comportamiento de los patógenos, en las condiciones de ensayo, y que se pueden considerar en caso de detectarse un foco de 
infección, adicionándose a los resultados obtenidos por el resto de autores, en sus condiciones.

Además, se ha estudiado el comportamiento de las bacterias saprofitas presentes en los substratos tras los distintos tratamientos térmicos, observándose reacciones de antibiosis, aunque sólo se han obtenido en condiciones in vitro, y con resultados positivos contra la bacteria C.m.michiganensis. También resulta especialmente interesante, el aislamiento de diferentes bacterias empleadas para el control biológico de determinados patógenos, sobre todo en la búsqueda de alternativas para el control químico.

Todos los resultados apoyan la efectividad de adicionar los restos de cosecha al suelo (pero enterrados) con altos niveles de humedad, obteniéndose un doble beneficio: el aprovechamiento de las sustancias volátiles liberadas de su descomposición así como la eliminación de los restos vegetales que se abandonan tras la cosecha y que pueden actuar como importante fuente de infección. Además, la incorporación de estos restos en el suelo, supondrán un aporte extra de material orgánico, lo que permitirá una disminución en la adición de estiércoles, aporte que favorece el nivel de nutrientes en el suelo así como las características del suelo, principalmente, de su estructura.

Como conclusión general, se ha obtenido que la combinación de las técnicas de biofumigación empleando restos de cosecha (en este caso diferentes de tomate) junto con la solarización, que permite alcanzar temperaturas elevadas en el suelo, puede ensayarse en campo como alternativa al empleo de BM en España en el control de las enfermedades ocasionadas por bacterias fitopatógenas, efecto favorecido con las condiciones climáticas del país, combinación que se asocia con un incremento de rendimiento y mejora de productividad de los cultivos. 
4. Efecto de diferentes tratamientos sobre restos de coles de Bruselas para el control de la enfermedad de mancha en anillo causada por Mycosphaerella brassicicola

Como ya se ha expuesto anteriormente, los resultados obtenidos a continuación, aportan información acerca del efecto y comparación de los tratamientos de biocontrol más empleados en una de las zonas más afectadas por el hongo $M$. brassicicola, precisamente en restos de una brassica, y cuyos restos se abandonan sobre la superficie del suelo. Se busca el tratamiento que reduzca el inóculo fúngico para posteriores cultivos y se ensayan técnicas de determinación del nivel de virulencia, en relación con la presencia del patógeno. Para ello, se ha cuantificado el ADN sobre las distintas muestras y se ha comparado con la cuantificación patógenica mediante el método clásico de conteo de esporas.

Toda esta información supondrá una experiencia en condiciones de campo de las técnicas de biocontrol así como conocimientos sobre una de las técnicas más avanzadas de cuantificación de ADN, en relación con la presencia del patógeno; técnicas que podrían aplicarse también en los ensayos anteriores de biofumigación y biosolarización en condiciones controladas, aportando información sobre la presencia patogénica en restos de tomate y en substratos y que podrían compararse con los métodos seleccionados como los de conteo de colonias.

\subsection{Experiencia en campo}

Los estudios realizados de manera previa a la puesta en campo de la experiencia permitieron conocer las características del hongo M. brassicicola así como su comportamiento en las condiciones de laboratorio a las que se iban a someter a las muestras. El resultado más interesante respecto al manejo, se obtuvo respecto a la esporulación: en las placas de petri conteniendo agar-nutriente, con alta humedad y manteniéndolas en cámara a $18^{\circ} \mathrm{C}$ con un régimen de $16 \mathrm{~h}$ luz, $8 \mathrm{~h}$ oscuridad, las lesiones tardaron en esporular entre 10 y 14 días. 
La imagen de las esporas en el agar se recoge en la figura 33: tamaño de $20 \mu \mathrm{m}$ con aumentos 10x y fácilmente distinguibles por la presencia de un septo central; esporas que deberían ser contadas siguiendo la metodología descrita: en 8 zonas diferentes para cada placa, con sus repeticiones y para todos los tratamientos, con sus múltiples repeticiones.

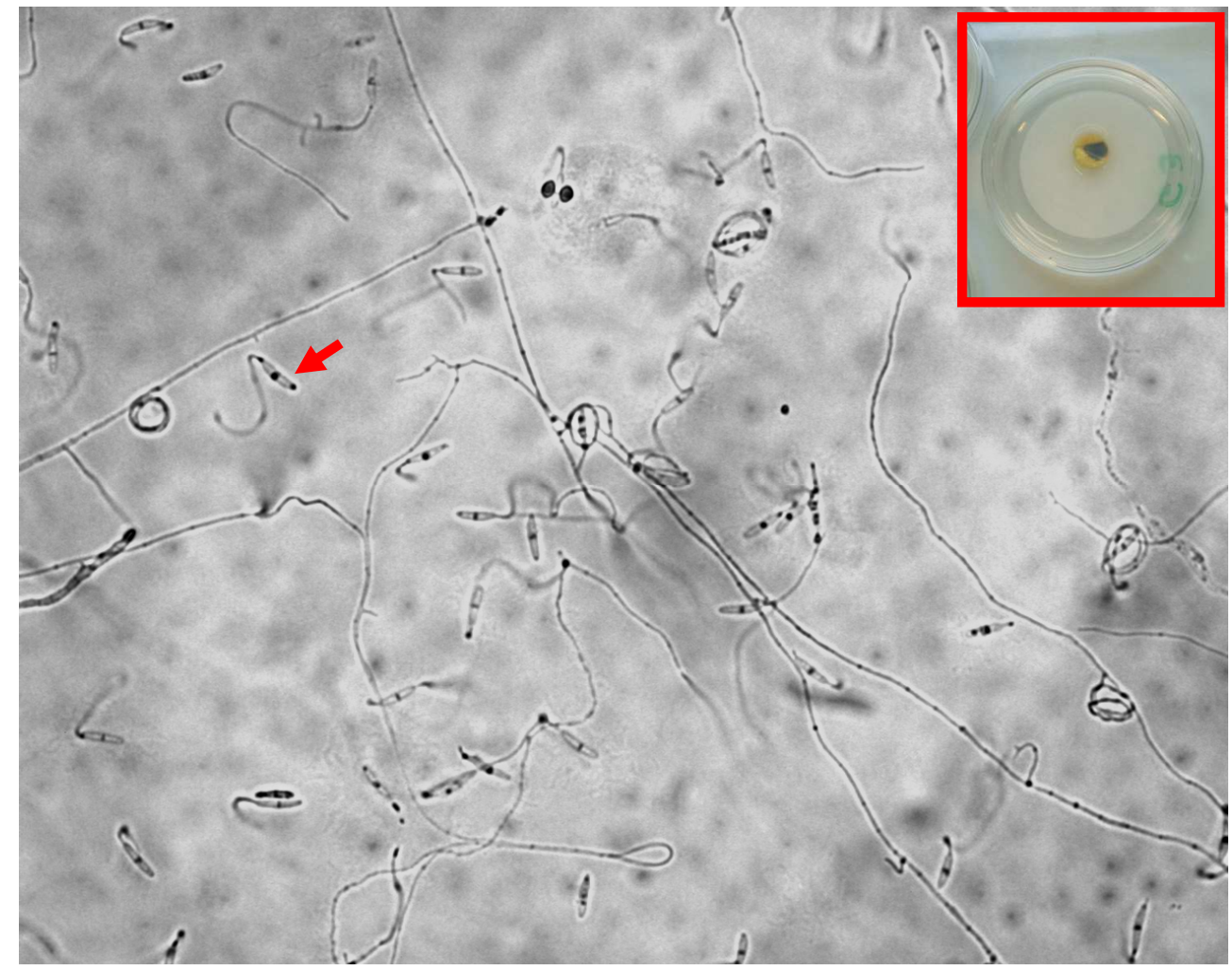

Figura 33. Esporas de M. brassicicola observadas en el microscopio óptico (20 x $1,25)$.

\subsubsection{Lesiones en hojas}

Las hojas recolectadas en las dos localidades seleccionadas, mostraron diferencias en cuanto a la presencia y características de las lesiones. De este modo, las hojas procedentes de la localidad A (campo biológico) se veían afectadas por un 
mayor número de lesiones de pequeño tamaño, mientras que las hojas de coles de Bruselas procedentes de la localidad B (campo tradicional) se veían afectadas por un menor número de lesiones pero de mayor tamaño. Estas diferencias se pueden observar en la figura 34.

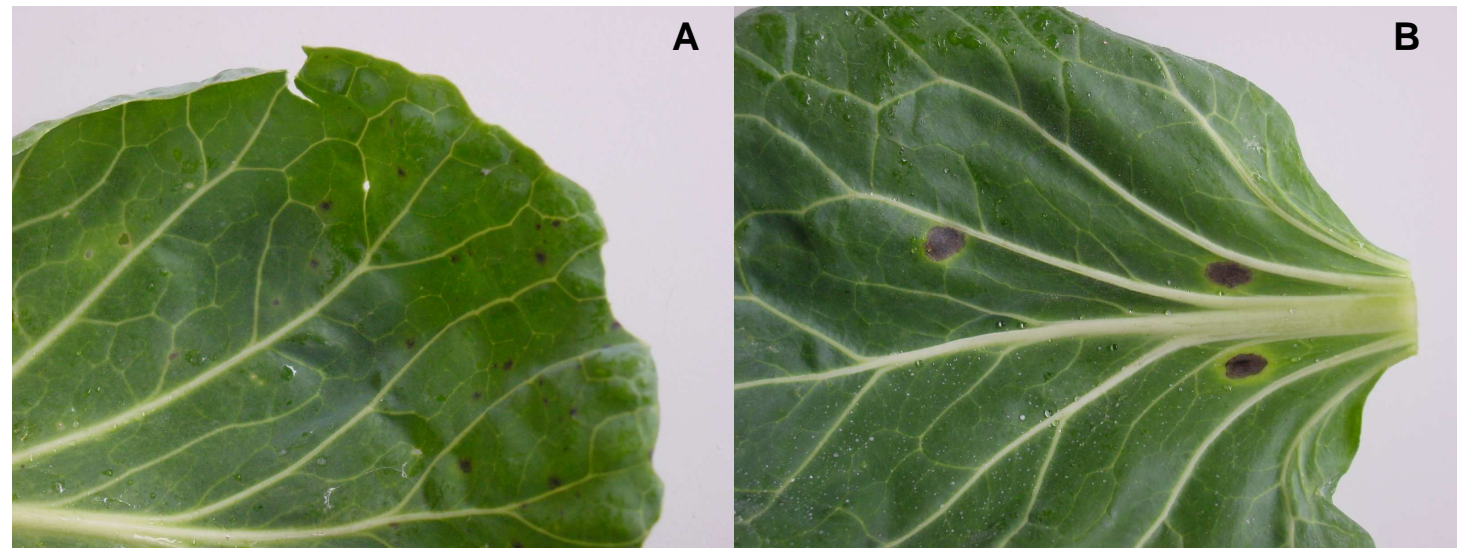

Figura 34. Lesiones de mancha en anillo, causadas por M. brassicicola, observadas en hojas procedentes de las localidades A (campo biológico) y B (campo tradicional)

Una vez que todas las hojas se colocaron en las parrillas y se distribuyeron en el campo, se aplicaron los diferentes tratamientos de la forma más uniforme posible, como se recoge en el anejo 2.

Para los dos muestreos T0 (previo al ensayo en campo) y T1 (transcurrido un mes desde la aplicación de tratamientos en campo) todas las hojas fueron procesadas y de cada una de ellas se seleccionó una lesión, extraída para el conteo de esporas. Los datos obtenidos correspondientes al número aproximado de lesiones en cada una de las hojas así como las medidas superficiales de cada lesión seleccionada $\left(\mathrm{mm}^{2}\right)$ se emplearon para calcular la superficie dañada para cada una de las muestras. Como resultado de este cálculo, se obtuvo que la superficie dañada en las hojas procedentes de la localidad A fuera significativamente mayor que para las hojas procedentes de la localidad B (figura 35). 
Transcurrido un mes desde que las parrillas fueran colocadas en el campo, y tratadas, se estimó la superficie dañada, observándose una evolución de modo que para $\mathrm{T} 1$ dicha superficie era mayor que para $\mathrm{T} 0$, justo en el inicio del experimento.

\section{Superficie dañada en hojas T0+T1}

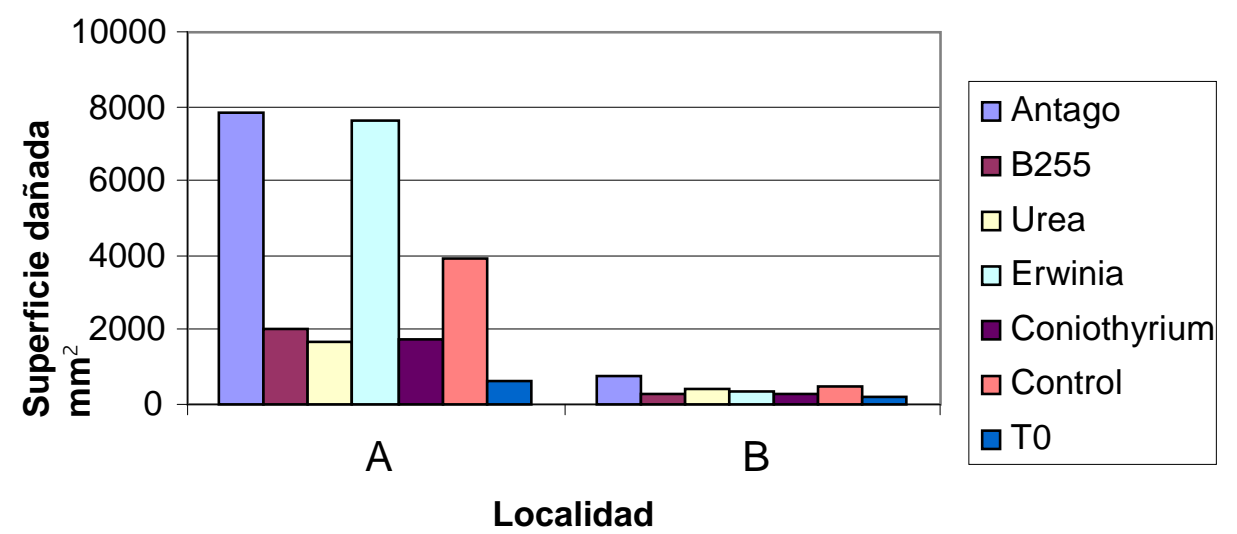

Figura 35. Estimación de la superficie dañada por localidad. Los valores para T0 (sin ningún tratamiento) y para T1 (diferentes tratamientos y control) se muestran juntos (datos numéricos recogidos en el anejo 3)

Para T1, los análisis estadísticos de la varianza para la superficie dañada, tras la transformación logarítmica de los datos $(\operatorname{Ln}(x+1)$, donde $\mathrm{x}$ es la superficie dañada), no mostraron interacciones entre localidad y tratamientos. Además, tras un mes desde la aplicación, las hojas tratadas con el hongo antagonista y con la bacteria E. carotovora, no mostraron diferencias significativas respecto al tratamiento control (empleando agua-Tween). Los mejores resultados, expresados como la menor superficie dañada, se obtuvieron para las hojas que fueron pulverizadas con el hongo C. pyrimum y con la bacteria B255, que mostraron diferencias significativas con respecto al tratamiento control (tabla 22). 
Transcurrido 1 mes desde los tratamientos, las hojas procedentes de la localidad A, mostraron una superficie dañada significativamente mayor que las hojas procedentes de la localidad B (tabla 22).

Tabla 22. Diferencia de superficie dañada $\left(\mathrm{mm}^{2}\right)$ en las hojas transcurrido un mes desde los diferentes tratamientos (T1). Datos numéricos en anejo 3.

\begin{tabular}{clcc}
\hline \multicolumn{5}{c}{$\mathrm{mm}^{2}$ superficie dañada $(\operatorname{Ln}(\mathrm{x}+1))$ por hoja } \\
\hline Tratamiento & \multicolumn{4}{c}{ Localidad } \\
\hline Antago & $7.58 \mathrm{a}^{\mathrm{x}}(1957.628)^{\mathrm{y}}$ & $\mathrm{A}$ & $7.98 \mathrm{a}(2920.931)$ \\
Erwinia & $7.34 \mathrm{ab}(1539.712)$ & $\mathrm{B}$ & $5.87 \mathrm{~b}(353.248)$ \\
Control & $7.02 \mathrm{ab}(1118.786)$ & & \\
Urea & $6.60 \mathrm{bc}(734.095)$ & & \\
Coniot & $6.57 \mathrm{c}(712.369)$ & & \\
B255 & 6.43 & $\mathrm{c}(620.173)$ &
\end{tabular}

${ }^{x}$ Los valores de cada columna seguidos por la misma letra no difieren significativamente de acuerdo con el método LSD de Fisher con un nivel de probabilidad del $95 \%$

${ }^{\mathrm{y}}$ Valores medios por replicado y localidad. Valores transformados de los expresados entre paréntesis

\subsubsection{Conteo de esporas}

Cabe recordar que el muestreo T0, estaba formado por 6 muestras que se recogieron en el momento previo a la disposición de las parrillas en el campo. Estaba formado por 3 grupos de 8 hojas, para cada localidad. 48 hojas, de las que se seleccionó una lesión. Para cada una de las 48 lesiones, que esporularon en el agar, se realizaron 8 conteos de esporas.

En función de los resultados para la esporulación, bajo las condiciones seleccionadas $\left(15^{\circ} \mathrm{C}, 16 / 8 \mathrm{~h}\right.$ luz/oscuridad) la primera liberación de esporas se observó transcurridos 10 días. De este modo se decidió realizar doble conteo de 
todas las placas: transcurridos 11 días y, luego, se colocaba una nueva placa de agar sobre la lesión para un nuevo conteo transcurridos 3 días más (día 14).

Para las muestras transcurridos un mes, para T1, en las mismas condiciones y mismo tratamiento de las muestras que para T0, la liberación de esporas se observó transcurridos sólo 5 días de incubación. En función de estos resultados, los conteos se adelantaron a los 6 y se repitieron transcurridos otros 6 (día 12), intentando capturar el mayor número de esporas.

La comparación entre los dos momentos de muestreo (tabla 23), recoge los diferentes porcentajes de lesiones que esporularon, pues no todas las seleccionadas lo hicieron, obteniendo como resultado que el porcentaje de lesiones que esporularon durante T0 difería en función de la localidad de procedencia, pero, transcurrido un mes y comparando con los resultados obtenidos para T0, el porcentaje de lesiones que esporularon fue el mismo para las dos localidades.

En datos generales, el número de ascosporas fue inferior para $\mathrm{T} 1$ y no se observaron diferencias significativas entre localidades. Sin embargo, para T0, el número de ascosporas era mayor para la las lesiones procedentes de la localidad B.

Respecto al tamaño de lesiones, este siempre se mantuvo mayor para las lesiones de hojas procedentes de la localidad B.

En general y transcurrido un mes, el tamaño de las lesiones evolucionó aumentando de forma considerable. 
Tabla 23. Comparación de esporulación entre lesiones de hojas procedentes de distintas localidades

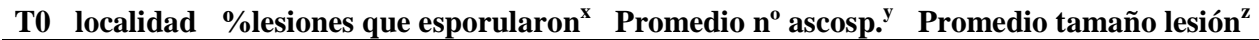

\begin{tabular}{ccccc}
\hline & A & 45,833 & 68,817 & 44,91 \\
& B & 90,509 & 96,641 & 61,25 \\
\hline T1 & A & 85,481 & 23,493 & 67,889 \\
& B & 85,648 & 26,722 & 107,723 \\
\hline
\end{tabular}

${ }^{\mathrm{x}}$ Porcentaje de lesiones que esporularon: para $\mathrm{T} 0$ cada valor es el promedio de 24 lesiones y para $\mathrm{T} 1$ cada valor es el promedio de 162 lesiones (packs incluidos)

${ }^{\mathrm{y}}$ Promedio de ascosporas por $\mathrm{mm}^{2}$ : para T0 cada valor es promedio de 192 conteos (8 conteos por lesión y 8 lesiones por localidad con 3 repeticiones). Para T1 cada valor es el promedio de 1296 conteos, incluyendo paks ( 8 conteos por lesión, 8 lesiones por muestra, 6 tratamientos, con 3 repeticiones y para 3 posiciones en los packs, 8 conteos por lesión, 2 lesiones por muestra y con 3 repeticiones). Todos los conteos se realizaron 2 veces.

${ }^{\mathrm{z}}$ Tamaño de las lesiones $\left(\mathrm{mm}^{2}\right)$ : para T0 cada valor es el promedio de 48 lesiones y para T1 cada valor es el promedio de 162 lesiones (packs incluidos)

Los análisis estadísticos de la varianza para $\mathrm{T} 1$ (tabla 24), tras la transformación logarítmica de $\operatorname{los}$ datos $(\log (x+1)$, donde $\mathrm{x}$ es el número de ascosporas por $\mathrm{mm}^{2}$ ) mostraron diferencias significativas entre tratamientos pero no entre localidades y tratamientos. Transcurrido un mes de la aplicación, las hojas tratadas con urea produjeron menos ascosporas que las consideradas como control, incluso que las tratadas con antagonistas, mostrando diferencias significativas. Por otro lado, las hojas tratadas con la bacteria B255 produjeron, también de forma significativa, menos ascosporas que las tratadas con Erwinia y con Coniothyrium. 
Tabla 24. Diferencia de ascosporas $(\log (x+1)$ donde $x$ es el número de esporas por $\mathrm{mm}^{2}$ ) en las muestras sometidas a distintos tratamientos. Datos numéricos en anejo 4.

\begin{tabular}{cl}
\hline \multicolumn{2}{c}{ Ascosporas $(\log (\mathrm{x}+1))$} \\
\hline Tratamiento & \\
\hline Erwinia & $1.69 \mathrm{a}^{\mathrm{x}}(49)^{\mathrm{y}}$ \\
Coniot & $1.68 \mathrm{ab}(47.86)$ \\
Antago. & $1.39 \mathrm{abc}(24.66)$ \\
Control & $1.35 \mathrm{abcd}(22.38)$ \\
B255 & $0.96 \quad \mathrm{~cd}(8.12)$ \\
Urea & $0.45 \quad \mathrm{e} \mathrm{(2.81)}$ \\
\hline
\end{tabular}

${ }^{x}$ Los valores en cada columna seguidos por la misma letra no difieren significativamente de acuerdo con el método LSD de Fisher, con un nivel de probabilidad del 95\%

${ }^{\mathrm{y}}$ Los valotes son promedios por replicado y localidad. Los valores sin transformar se muestran entre paréntesis

Estos resultados muestran que el tratamiento con urea se mostró como el mejor tratamiento para reducir la esporulación de las lesiones.

\subsubsection{Cuantificación de ADN: PCR en tiempo real}

La cuantificación de ADN realizada para todas las muestras de T0 y T1 mostró que aquellas en las muestras procedentes de la localidad A (campo biológico), se detectaban menores cantidades de de ADN de $M$. brassicicola que para las muestras procedentes del campo B (con tratamientos tradicionales).

Respecto a los tiempos de muestreo, también se observaron diferencias, de modo que para $\mathrm{T} 0$ se detectaron menores cantidades de ADN que para las muestras del T1, evidenciando la evolución de la enfermedad transcurrido un mes del abandono de las muestras en la superficie del suelo.

Todos estos resultados se recogen en la figura 36. 
Por otra parte, los resultados del estudio estadístico de cuantificación de ADN comparando el efecto de los distintos tratamientos para el periodo de muestreo $\mathrm{T} 1$, se recogen en la tabla 25 .

\section{Resultados taq T0+T1}

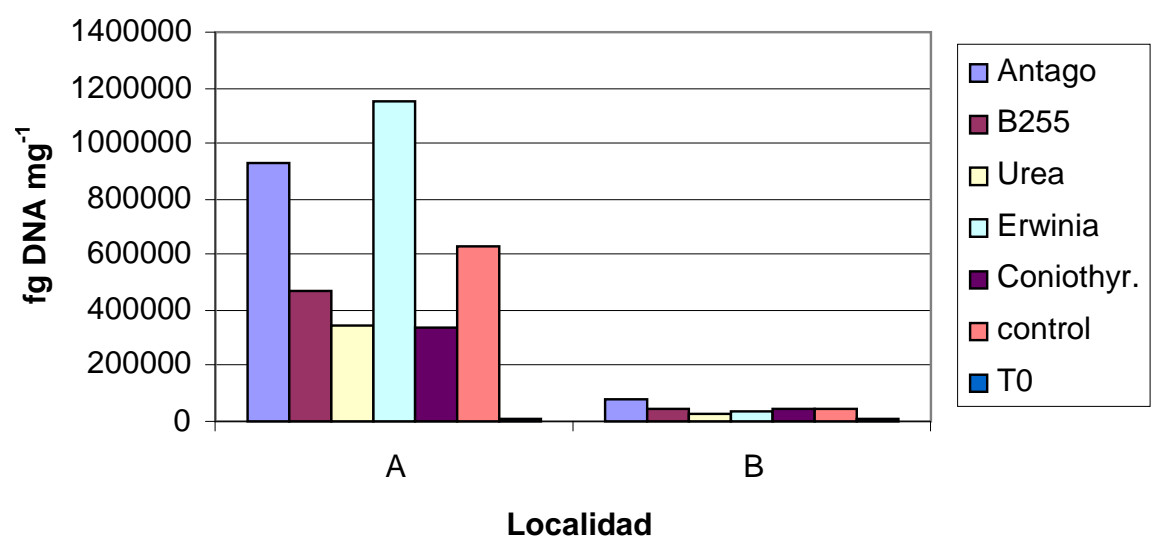

Figura 36. Resultados de la cuantificación de ADN de M. brassicicola (fg ADN $\mathrm{mg}^{-1}$ de peso seco) por localidad. Los valores para T0 (sin ningún tipo de tratamiento) y para $\mathrm{T} 1$ (diferentes tratamientos y control) se muestran conjuntamente. Datos numéricos en anejo 5.

Los análisis de varianza para T1, tras la transformación logarítmica de los datos $\left(\operatorname{Ln}(\mathrm{x}+1)\right.$ donde $\mathrm{x}$ es la cantidad de $\mathrm{ADN}$ en $\left.\mathrm{fg}_{\mathrm{mg}}^{-1}\right)$ no mostraron interacciones en tre localidad y tratamiento. Así, de los resultados recogidos en la tabla 16, se observa que transcurrido un mes tras la aplicación de los tratamientos, no existen diferencias significativas para la disminución de la enfermedad causada por M. brassicicola, con respecto al tratamiento control excepto para las muestras tratadas con urea. De los datos se deduce que este tratamiento redujo la cantidad de ADN fúngico en un $52 \%$. 
Tabla 25. Diferencia en la cuantificación de ADN de M. brassicicola para los diferentes tratamientos para $\mathrm{T} 1$

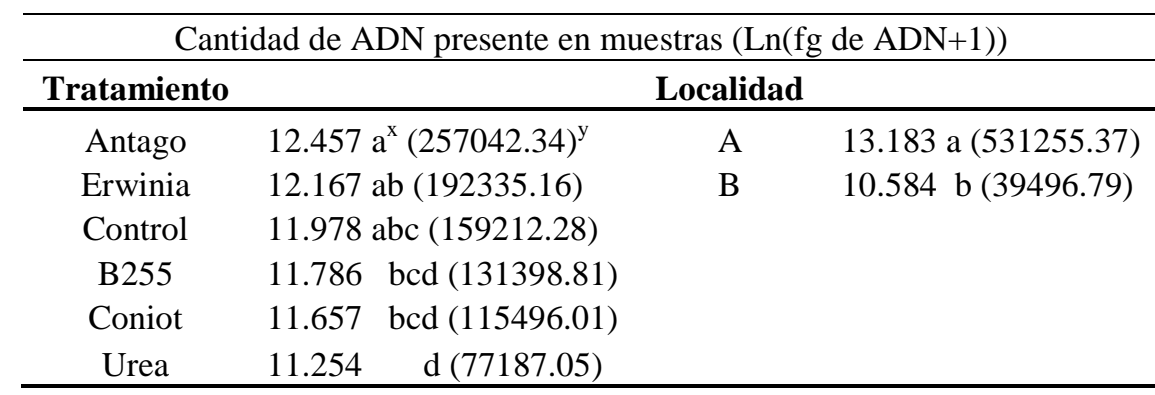

${ }^{\mathrm{x}}$ Los valores en cada columna seguidos por la misma letra no difieren significativamente de acuerdo con el método LSD de Fisher, con un nivel de probabilidad del $95 \%$

${ }^{\mathrm{y}}$ Los valotes son promedios por replicado y localidad. Los valores sin transformar se muestran entre paréntesis

En la figura 37 se recoge la relación entre todos los valores obtenidos referidos a las cantidades de ADN de M. brassicicola y la estimación de la superficie dañada. Como resultado se obtuvo que existía una relación lineal y directa de modo que las cantidades detectadas de ADN de $M$. brassicicola son mayores cuando la superficie dañada es mayor. 


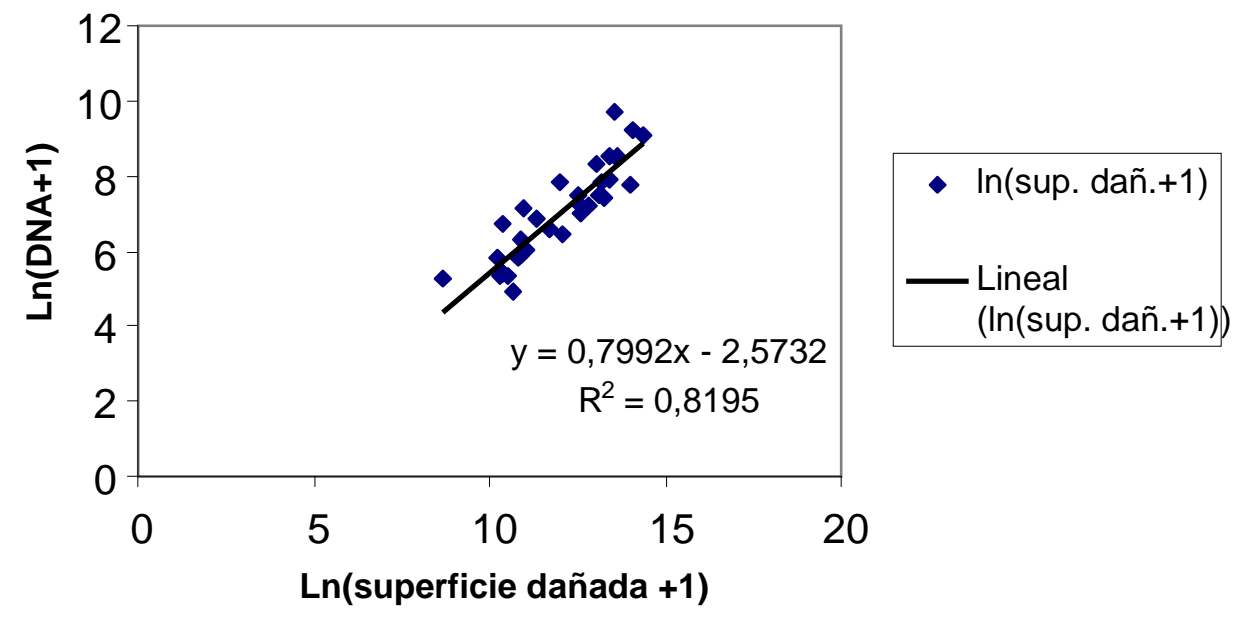

Figura 37. Relación entre las cantidades de $\mathrm{ADN}\left(\mathrm{fg} \mathrm{mg}^{-1}\right)$ y la superficie dañada en las hojas afectadas $\left(\mathrm{mm}^{2}\right)$. Datos numéricos en anejo 6.

\subsubsection{Descomposición de las hojas en función de los tratamientos}

La descomposición de las hojas tras la aplicación de los tratamientos, se estimó mediante la comparación de la evolución de las hojas sobre la superficie del campo en los periodos de muestreo T0 y T1 y el resultado se recoge en la figura 38.

Los análisis estadísticos de la varianza para el estudio de la descomposición de las hojas, indicaron deferencias significativas entre localidades (fácilmente observables en la figura 38), pero no entre tratamientos.

En función de estos resultados, el nivel de descomposición para las hojas procedentes de la localidad A era mayor que para el observado en las hojas de la localidad B, aunque todas las hojas fueron recolectadas, colocadas en campo y tratadas al mismo tiempo, con los mismos tratamientos y en las mismas condiciones.

Esta diferencia en la velocidad de descomposición podría afectar a los posteriores muestreos, puesto que según el calendario de la experiencia había que mantener las hojas en campo hasta un máximo de 3 meses. 


\section{\% de descomposición (del 5.10 al 15.11)}

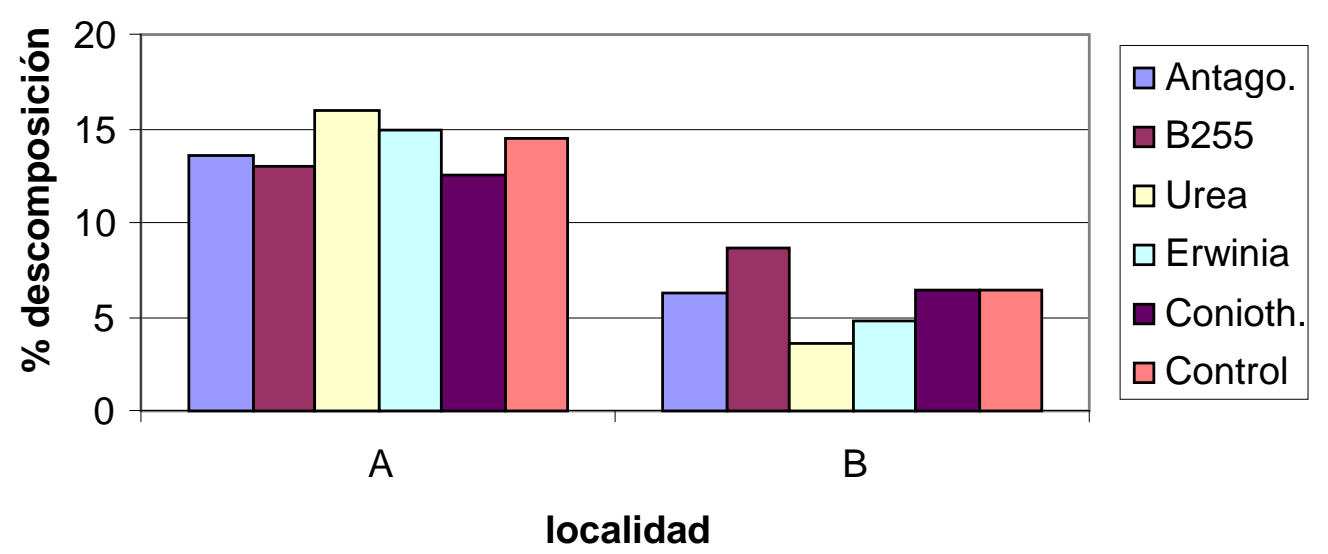

Figura 38. Porcentaje de descomposición de las hojas tras un mes de la aplicación de los tratamientos. Datos numéricos en anejo 6.

\subsubsection{Efectos observados en los packs de hojas ensayados}

Respecto a los efectos de la descomposición en packs, realizado para comparar los efectos en tres niveles diferentes de un grupo de hojas, puesto que la mayoría de las veces no sólo aparece una única hoja sobre la superficie del suelo y, aparentemente, la evolución del patógeno podría suponerse diferente en las hojas situadas más externamente (en contacto directo con las condiciones ambientales), que en hojas situadas en las zonas centrales (y más tratándose de brassicas, con el conocido efecto de liberación de isotiocianatos) y que en las hojas en posiciones inferiores (que se mantienen en contacto directo con el suelo, incluso sometidas a la actividad antagonista de organismos y compuestos del mismo).

Así, los resultados obtenidos en función de los efectos observados en estas tres zonas diferentes de los packs, están referidos a la esporulación de lesiones y a las cantidades de ADN de M. brassicicola detectadas. 
Los resultados, recogidos en la tabla 26, indican una menor liberación de esporas y menores cantidades de ADN en las muestras correspondientes a las hojas localizadas en la zona central, aunque los análisis estadísticos (para el primer mes transcurrido desde la aplicación de los tratamientos) no muestres diferencias significativas entre las tres zonas.

Tabla 26. Ascosporas y cuantificación de ADN en las diferentes posiciones de los packs.

\begin{tabular}{cccc} 
Localidad & Pack & Ascosporas $\left(\mathrm{mm}^{2}\right)$ & ADN $\left(\mathrm{fg} \mathrm{mg}^{-1}\right)$ \\
\hline $\mathrm{A}$ & Superior & 5,04 & 804819 \\
& Centro & 2,752 & 524199 \\
& Inferior & 13,256 & 715645 \\
\hline B & Superior & 9,375 & 80737 \\
& Centro & 1,831 & 57769 \\
& Inferior & 5,472 & 75183 \\
\hline
\end{tabular}

\subsection{Control de $M$. brassicicola en restos de coles de Bruselas: Discusión general}

La aparición de síntomas relacionados con la presencia del hongo $M$. brassicicola se produce de forma mayoritaria durante el final del verano y durante todo el otoño, coincidiendo con el momento óptimo de desarrollo de las plantas de coles de Bruselas y con las condiciones óptimas para el desarrollo de la enfermedad asociada al hongo (entre $5-20{ }^{\circ} \mathrm{C}$ y un $98 \%$ de HR), según recoge Van den Ende (1993 a).

Como se ha indicado, las hojas afectadas empleadas en este trabajo se seleccionaron en dos localidades con diferente manejo en los campos (ecológico y tradicional). Las diferencias observadas en el nivel inicial de infección, referente al número y tamaño de lesiones, puede relacionarse con esta procedencia. Así, las hojas procedentes del campo sometido a un manejo biológico mostraban un mayor 
número de lesiones pero de menor tamaño y, en función de los resultados, la superficie total afectada para las hojas seleccionadas también era mayor, siendo este un dato importante a considerar en el momento de cuantificación de patógenos.

La superficie foliar dañada en las hojas medida al comienzo del experimento, fue inferior a la observada un mes más tarde en el campo, independientemente de los diferentes tratamientos aplicados. Esta tendencia difiere en función del origen de las hojas, de modo que las hojas procedentes del campo convencional mostraron una menor superficie dañada en comparación con las hojas procedentes del campo biológico. Además, se observó que los tratamientos ensayados con el objetivo de acelerar la descomposición no redujeron los daños, incluso los niveles más elevados de infección, en las hojas del campo biológico, se detectaron tras los tratamientos con E. carotovora. Este resultado concuerda con los obtenidos en aquellos trabajos en los que se sugiere la combinación de defoliantes con fungicidas, como los aportados por Lorezco y Mariano (2003) para el control de la enfermedad de mancha en anillo pero en coles.

Respecto a las condiciones óptimas para la liberación de esporas en los diferentes momentos de muestreo, se obtuvieron resultados variados. Así, para las primeras lesiones seleccionadas (T0) la esporulación con la liberación de esporas tuvo lugar transcurridos 10 días desde que se colocaron en las condiciones de ensayo en el laboratorio (en cámara a $15^{\circ} \mathrm{C}$ y $98 \% \mathrm{HR}$, con $16 / 8$ luz/oscuridad) y la liberación de esporas continuó hasta llegar al día 14. Sin embargo, para las mismas condiciones, pero para las lesiones procedentes tras el primer mes de la aplicación de tratamientos (T1) la esporulación se adelantó observándose la liberación de esporas a partir del día 5. Resultados que también concuerdan con los datos aportados por Kennedy et al. (1999) y por Van den Ende (1998) que indicaron que las ascosporas de M. brassicicola pueden germinar en un amplio rango de temperaturas en presencia de agua libre. De acuardo con Götz et al. (1993) la producción de ascosporas de $M$. brassicicola pueden ser diferentes en el 
caso de condiciones in vitro en función de la variación de temperaturas, del $\mathrm{pH}$ del medio ensayado y de las condiciones de iluminación. En este trabajo y para evitar grandes variaciones en la esporulación, todas las lesiones obtenidas de los diferentes muestreos se sometieron a condiciones controladas idénticas. Debido a estas condiciones, la diferencia observada para la esporulación entre muestreos se relacionaría con el momento del muestreo y con la edad de las lesiones. En función de todo lo anterior se puede concluir que las lesiones más jóvenes necesitan más tiempo para esporular.

También se observó una variación interesante entre el número de lesiones que esporularon en función de las diferentes localidades y en el caso del primer muestreo (T0), de modo que de acuerdo con este resultado produjeron más esporas las lesiones procedentes del campo tratado de forma convencional. Sin embargo, transcurrido un mes, se igualó el porcentaje de esporulación de las lesiones. Este resultado adquiere una gran relevancia debido a que, todas las lesiones independientemente del lugar de procedencia, presentan el mismo riesgo de comportarse como importante fuente de inóculo conforme van madurando.

Transcurrido un mes tras la aplicación de los diferentes tratamientos, sólo las hojas que fueron pulverizadas con urea mostraron menor producción de esporas en comparación con las hojas pulverizadas con la solución control (agua -Tween). De acuerdo con este resultado, la aplicación de urea se mostró como el mejor tratamiento contra la esporulación de M. brassicicola en las lesiones tratadas.

Los resultados de cuantificación de ADN de M. brassicicola mostraron diferencias en función de la procedencia de las lesiones. Estas diferencias podrían relacionarse con las diferencias ya comentadas respecto a la superficie dañada, ya que las mayores cantidades de ADN se obtuvieron cuando la superficie dañada aumentaba. La comparación de tratamientos mostró que sólo la aplicación de urea redujo la presencia de $\mathrm{ADN}$ respecto al tratamiento control. De nuevo, y según este resultado, el tratamiento con urea se mostró como el mejor para el control de $M$. brassicicola reduciendo los riesgos de reinfectación desde los restos de cosecha. 
Respecto a la descomposición observada transcurridas 6 semanas desde la aplicación de los diferentes tratamientos, sólo se encontraron diferencias entre las localidades de procedencia pero no entre los diferentes tratamientos. Esta diferencia parece estar relacionada con la calidad de las hojas.

Así, de acuerdo con Van den Ende (1993 b), los efectos de la edad de las plantas respecto al desarrollo del patógeno son importantes en la expresión de la enfermedad. En función de estos resultados, la necesidad de seleccionar hojas lo más uniformes posibles resultaría un factor primordial en todos los ensayos experimentales.

Para concluir, cabe recordar que este trabajo forma parte de un ensayo que permaneció en campo durante tres meses, mostrándose sólo los resultados correspondientes al primer mes de muestreo. 



\section{CONCLUSIONES}

Respecto al empleo de la biofumigación y biosolarización para el control de C.m.michiganensis:

1. Bajo condiciones controladas, de laboratorio y de invernadero, tras 6 semanas de tratamiento a $25{ }^{\circ} \mathrm{C}$, tratamiento considerado como biofumigación, C.m.michiganensis no fue erradicado en aquellas macetas que permanecieron abiertas y que fueron enmendadas con residuos frescos de tomate previamente infectados, de forma artificial, con el patógeno

2. C.m.michiganensis no se detectó tras 4 semanas de tratamiento a $25^{\circ} \mathrm{C}$ en macetas enmendadas y que permanecieron encerradas en bolsas de plástico, evitando la salida de sustancias volátiles producidas durante la descomposición del material vegetal

3. Bajo condiciones controladas, de laboratorio y de invernadero, tras 4 semanas de tratamiento a $45{ }^{\circ} \mathrm{C}$, considerado como biosolarización, C.m.michiganensis no fue erradicado tras los tratamientos en aquellas macetas que permanecieron abiertas

4. C.m.michiganensis no se detectó tras 2 semanas de tratamiento a $45^{\circ} \mathrm{C}$ en las macetas que permanecieron encerradas en bolsas de plástico

5. Respecto a la introducción y posterior recuperación de C.m.michiganensis en substratos artificialmente infectados, las poblaciones del patógeno sufrieron un fuerte descenso tras 4 semanas de tratamiento a $25^{\circ} \mathrm{C}$ o tras 1 semana a $45{ }^{\circ} \mathrm{C}$, tratamiento tras el que nunca se detectan colonias de C.m.michiganensis

6. Respecto al estudio de supervivencia de C.m.michiganensis en asociación con los residuos vegetales, el patógeno permaneció infectivo tras 4 semanas de tratamientos a $25^{\circ} \mathrm{C}$ y a $45^{\circ} \mathrm{C}$.

7. Se observó reacción de antagonismo In Vitro entre Bacillus subtilis y C.m.michiganensis 
Respecto al uso de biofumigación y biosolarización para el control de $R$. solanacearum:

8. Bajo condiciones controladas de laboratorio y de invernadero, tras un tratamiento de 6 semanas a $25{ }^{\circ} \mathrm{C}$, considerado como un tratamiento de biofumigación, $R$. solanacearum no fue erradicada en macetas abiertas o cerradas que fueron enmendadas con restos de tomate artificialmente infectados con el patógeno

9. R. solanacearum no se detectó en las macetas, abiertas o cerradas, tras los tratamientos a $45^{\circ} \mathrm{C}$

10. Respecto a la introducción y recuperación de $R$. solanacearum en substratos infectados de forma artificial, se detectaron colonias del patógeno tras 6 semanas de tratamientos a $25{ }^{\circ} \mathrm{C}$, mostrando reacciones positivas tras su inoculación en hojas de tabaco. No se detectaron colonias de $R$. solanacearum tras 1 semana de tratamiento a $45^{\circ} \mathrm{C}$

11. Respecto a la determinación y supervivencia de $R$. solanacearum en asociación con el tejido vegetal infectado, las suspensiones bacterianas obtenidas tras los tratamientos e infiltradas en hojas de tabaco mostraron reacciones negativas

12. La biosolarización se mostró como el mejor de los tratamientos para el control de bacterias patógenas. Es importante considerar estos resultados respecto al efecto de las diferentes técnicas de desinfección del suelo o entre las alternativas ecológicas

Respecto al efecto de los diferentes tratamientos sobre residuos de coles de Bruselas para controlar la enfermedad causada por M. brassicicola:

13. La aplicación de urea resultó el mejor tratamiento contra la esporulación de M. brassicicola 
14. Todos los residuos de M. brassicicola obtenidos en campos tratados de forma diferente (orgánicos o convencionales) suponen el mismo riesgo respecto a la producción de inóculo infectivo

15. La cuantificación de ADN de M. brassicicola mostró que las mayores cantidades de ADN se obtienen cuando mayor es la superficie dañada

16. La edad de las hojas juegan un papel importante en la expresión de la enfermedad causada por M. brassicicola. La necesidad de seleccionar las hojas lo más uniformes posibles se convierte en un factor de importancia en aquellos experimentos con propósitos comparativos 



\section{CONCLUSIONS}

With regard to the use of biofumigation and biosolariation for the control of C.m.michiganensis:

1. Under laboratory and greenhouse conditions after a 6-week treatment at 25 ${ }^{\circ} \mathrm{C}$, considered as biofumigation, C.m.michiganensis was not eradicated after treatments in open pots that were amended with fresh tomato debris which was either artificially infected with the pathogen

2. C.m.michiganensis was not detected in the amended pots after a 4-weeks treatment at $25{ }^{\circ} \mathrm{C}$ in pots that were enclosed in plastic bags to avoid the release of volatile substances produced during the decomposition of the plant material

3. Under laboratory and greenhouse conditions after a 4-week treatment at 45 ${ }^{\circ} \mathrm{C}$, considered as biosolarization, C.m.michiganensis was not eradicated after treatments in open pots

4. C.m.michiganensis was not detected in the amended pots after a 2-weeks treatment at $45^{\circ} \mathrm{C}$ in pots that were enclosed in plastic bags

5. With regard to the introduction and recovery of C.m.michiganensis from artificially infected substrate, population densities of the pathogen displayed a slight decrease after a 4 -week treatment at $25{ }^{\circ} \mathrm{C}$ or after 1 week at $45^{\circ} \mathrm{C}$, when no cells of C.m.michiganensis were detected

6. With regard to the determination of the longevity of the pathogen in association with the host tissue, C.m.michiganensis remained pathogenic after 4 weeks of either thermal treatment at $25^{\circ} \mathrm{C}$ and $45^{\circ} \mathrm{C}$

7. In Vitro antagonism between Bacillus subtilis and C.m.michiganensis was observed 
With regard to the use of biofumigation and biosolariation for the control of $R$. solanacearum:

8. Under laboratory and greenhouse conditions after a 6-week treatment at 25 ${ }^{\circ} \mathrm{C}$, considered as biofumigation, $R$. solanacearum was not eradicated after treatments in open or enclosed pots that were amended with fresh tomato debris which was either artificially infected with the pathogen

9. R. solanacearum was not detected in the amended pots after treatments at $45^{\circ} \mathrm{C}$ in open or enclosed pots

10. With regard to the introduction and recovery of $R$. solanacearum from artificially infected substrate, colonies of the pathogen were detected after a 6-week treatment at $25^{\circ} \mathrm{C}$, showing positive reactions in tobacco leaves. After 1 week at $45^{\circ} \mathrm{C}$ no cells of $R$. solanacearum were detected

11. With regard to the determination of the longevity of the $R$. solanacearum in association with the host tissue, bacterial suspensions obtained after the treatments and infiltrated in tobacco leaves showed negative reactions

12. Biosolarization was the best treatment for the control of pathogenic bacteria. It is important to take these results into account with regard the effect of different soil dissinfection techniques or ecological alternatives

With regard to the effect of different treatments on Brussels sprouts debris to control the ring spot disease caused by M. brassicicola:

13. Application of urea was the best treatment against the sporulation of $M$. brassicicola in the treated lesions

14. All M. brassicicola debris obtained from differently treated fields (organically or conventionaly treated) has the same risk of inoculum production

15. M. brassicicola DNA quantifications showed that higher amounts of DNA are obtained when the damage surface is bigger 
16. Leaf age plays an important role in the expression of the disease caused by M. brassicicola. The need to select leaves as uniform as possible is an important factor for comparative experiments 



\section{BIBLIOGRAFÍA}

Abawi G.S., Widmer T.L. 2000. Impact of soil health management practices on soilborne pathogens, nematodes and root diseases of vegetable crops. App. Soil Ecol. 15: 37-47.

Abdel-Mallek A.Y., Hasan H.A.H., Bagy M.M.K. 1995. Efficacy of hydrocarbons against soybean seed-borne fungi and aflatoxins production. Seed science and technology 23: 183-192.

Adams P.B. 1990. The potential of mycoparasites for biological control of plant diseases. Annual Review of Phytopathology 28: 59-72.

Agrios G.N. 2002. Fitopatología. Limusa, grupo Noriega de editores. México. 837pp.

Aguilar M.I. 2002. Efectos del compostaje de residuos de plantas hortícolas infectadas sobre la viabilidad de hongos y virus fitopatógenos. Tesis doctoral. Departamento de biología aplicada. Universidad de Almería. 218 pp.

Aguirre J. 1963. Suelos, abonos y enmiendas. Ed. Dossat, S.A. Madrid. 433 pp.

Aguirre J. 1971. Divulgación de abonos. Fertilizantes nitrogenados nacionales, S.A. Ed. Aro-Artes gráficas. Madrid. 204 pp.

Aguirre I., Carmona I., López-Martínez N., Cuaresma I., González-Zamora J.E., Avilla C., López-Medina I. 2004. Influencia de la biofumigación en la productividad y precocidad del cultivo ecológico de fresón. Comunicaciones del VI congreso de la SEAE. Almería, 27 Septiembre-2 Octubre, 2004. pp. 303-312.

Agustí L., Bonaterra A., Moragrega C., Montesinos E. 2006a. Control biológico de Phytophthora cactorum en fresón (Fragaria x Ananassa) mediante cepas de Pseudomonas fluorescens y Pantoea agglomerans, y determinación de posibles mecanismos de acción. Libro de resúmenes del XIII congreso de la SEF. Murcia, 18-22 septiembre 2006. p. 150.

Agustí L., Bonaterra A., Moragrega C., Pinochet J., Montesinos E. 2006 b. Control biológico del nematodo agallador Meloidogyne javanica en portainjertos GF677 de Prunus sp. mediante cepas de Pseudomonas fluorescens y Pantoea agglomerans. Libro de resúmenes del XIII congreso de la SEF. Murcia, 18-22 septiembre 2006. p. 377. 
Ahmad I.A., Warren A.D. 2003. Myrosinase activity in soil. Soil Science Society of America Journal 67: 139-145.

Ajwa H.A., Klose S., Nelson S.D., Minuto A., Gullino M.L., Lamberti F., López-Aranda J.M. 2003. Alternatives to methyl bromide in strawberry production in the United States of America and the Mediterranean region. Phytopathologica Mediterranea 42: 220-244.

Akiew S., Trevorrow P. 1999. Biofumigation of bacterial wilt of tobacco. In: Proceedings $1^{\text {st }}$ Australasian Soilborne Disease Symposium, pp. 207-208. Magarey, R.C., Bureau of Sugar Experiment Stations, Brisbane.

Akiew S.E., Kirkegaard J.A., Robinson M.C., Hopkinson R. 2005. A laboratory screen for biofumigation-related suppression of Ralstonia solanacearum. Proceedings $15^{\text {th }}$ Biennial Australasian Plant Pathology Society Conference, pp.62. APPS, Geelong.

Alcalá D.M., Lara B. 1995. Estudio de la marchitez bacteriana de la papa en tres localidades del estado Lara. Agronomía Tropical 48: 275-289.

http://ceniap.inia.gov.ve/pbd/RevistasCientificas/Agronomia\%20Tropical/at4803/a rti/alcala_d.htm 26-8-08

Alexander M. 1980. Biodegradation of chemicals of environmental concern. Science 211: 132-138.

Alonso R., Alemany A., Andrés M.F. 2004. La solarización como método de control alternativo del nematodo formador de quistes de la patata (Globodera sp.) en Mallorca. Libro de resúmenes del XII congreso de la SEF. Lloret de Mar, Girona, 26 septiembre-1 octubre 2004. p. 326.

Álvarez B., Biosca E.G., López M.M. 2006. Caracterización de fagos líticos de Ralstonia solanacearum aislados de agua de río: uso potencial en biocontrol. Libro de resúmenes del XIII congreso de la SEF. Murcia, 18-22 septiembre 2006. p. 62.

Andrews J.M. 2004. BSAC standarized disc susceptibility testing method (version 3). J. Antimicrob. Chemoth. 53: 713-728.

Angus J.F., Grander P.A., Kirkegaard J.A., Desmarchelier J.M. 1994. Biofumigation: isothiocyanates released from Brassica roots inhibit growth of the take-all fungus. Plant and soil 162: 107-112. 
Antoniou P.P., Tjamos E.C., Panagopoulos G.G. 1995. Use of solarization for controlling bacterial canker of tomato in plastic houses in Greece. Plant Pathology 44: 438-447.

Aparicio V., Rodrígez M.D., Gómez V., Sáez E., Belda J.E., Casado E., Lastres J. 1995. Plagas y enfermedades de los principales cultivos hortícolas de la provincia de Almería: control racional. Ed. Junta de Andalucía, Consejería de Agricultura y Pesca. 260 pp.

Araud-Razoud I., Vasse J., Montrozier H., Etchebar C., Trigalet A. 1998. Detection and visualization of the major acidic exopolysaccharide of Ralstonia solanacearum and its role in tomato root infection and vascular colonization. European Journal of Plant Pathology 104: 795-809.

Arranz D., García-Casas M.V., Pollo A. 2006. Biofumigación y 1,3Dicloropropeno como alternativa al bromuro de metilo. Terralia 55.

Aryantha I.P., Cross R., Guest D.I. 2000. Suppression of Phytopthora cinnamomi in potting mixes amended with uncomposted and composted animal manures. Phytopathology 90, 775-782.

Ashworth L., Gaona S.A. 1982. Evaluation of clear polyethylene mulch for controlling Verticillium wilt in established pistachio nut groves. Phytopathology 72: $243-246$.

Bailey K.L., Lazarovits G. 2003. Supressing soilborne diseases with residue management and organic amendments. Soil Tillage Res. 72:169-180.

Baker K.F. 1987. Evolving concepts of biological control of plant pathogens. Annu. Rev. Phyopathol. 25: 67-85.

Baptista M.J., Dos Reis F.B., Ribeiro G., De Alcantara C., Regís A., Bartolomeu R., Lopes C.A. 2007. Efficiency of solarization and biofumigation on tomato bacterial wilt control in the field. Pesquisa Agropecuária Brasileira 42: 933938.

Barrau C., Porras M., Salas D., Ramos N., Soares C., Romero F. 2006. Efecto de biofumigación, solarización y biofungicidas sobre Phytophthora infestans en cultivo de tomate. Libro de resúmenes del XIII congreso de la SEF. Murcia, 18-22 septiembre 2006. p. 165. 
Barres M.T. 2006. La eliminación del bromuro de metilo en protección de cultivos como modelo mundial para la conservación del medio ambiente. Tesis doctoral. Departamento de Ecosistemas Agroforestales Universidad Politécnica de Valencia. $501 \mathrm{pp}$.

Basu P.K. 1970. Temperature, an important factor determining survival of Corynebacterium michiganense in soil. Phytopathology 60: 825-827.

Becker J.O., Schwinn F.J. 1993. Control of soil-borne pathogens with living bacteria and fungi: status and outlook. Pesticide Science 37, 355-363.

Bell A.A., Hubbard J.C., Liu L., Davis R.R., Subbarao-Krishna V. 1998. Effects of chitin and chitosan on the incidence and severity of fusarium yellows of celery. Plant Disease 82, 322-328.

Bellapart C. 1996. Nueva agricultura biológica en equilibrio con la agricultura química. Ediciones Mundi-Prensa. Barcelona, España. 299 pp.

Bello A. 1998. Biofumigation and integrated pest management. En: A. Bello, J.A. González, M. Arias, R. Rodríguez-Kábana (Eds). Alternatives to Methyl Bromide for the Southern European Countries. DG XI EU, CSIC, Valencia, 99-126.

Bello A. 2004. Alternativas al bromuro de metilo como fumigante de suelos. Horticultura, Extra 2004: 61-66.

Bello A., Escuer M., Sanz R., López J.A., Guirao P. 1997 a. Biofumigación, nematodos y bromuro de metilo en el cultivo del pimiento. En: A. López, J.A. Mora (Eds.) Posibilidad de alternativas viables al bromuro de metilo en pimiento de invernadero. Consejería de Medioambiente, Agricultura y Agua. Murcia, 67108.

Bello A., González J.A., Tello J.C. 1997 b. La biofumigación como alternativa a la desinfección el suelo. Horticultura Internacional 17, 41-43.

Bello A., González J.A., Arias M., Rodríguez-Kábana R. 1998. Alternatives to methyl bromide for the Southern European countries. DG XI, EU, CSIC, Valencia, Spain, 404 pp.

Bello A., Tello J. 1998. El bromuro de metilo se suprime como fumigante del suelo. Phytoma España 101: 10-21. 
Bello A., López J.A., Sanz R., Escuer M., Herrero J. 2000. Biofumigation and organic amendments. In: Methyl bromide alternatives for North African ans Southern European countries. Eds. UNEP, pp. 113-141.

Bello A., López-Pérez J.A., García-Álvarez A. 2002. Biofumigation as an alternative to methyl bromide. Proceedings of international conference on alternatives to methyl bromide. Sevilla, Spain 5-8 Marzo 2002. pp. 221-225.

Bello A., López-Pérez J.A., García-Álvarez A. 2003. Biofumigación y control de los patógenos de las plantas. En: Biofumigación en agricultura extensiva de regadío. Ed. Mundi-Prensa. Alicante. Pp. 343-369.

Bello A., García-Álvarez A., Díez-Rojo M.A. 2004. Ecología de suelos, manejo de la materia orgánica e investigación. En: Agrícola Española (Eds.). Conference book, I Internacional Conference on Soil and Compost Eco-Biology, 15-17 September 2004, León, España. Pp. 203-204.

Bello A., Díez Rojo M.A. 2004. Situación del bromuro de metilo como fumigante de suelo en el año 2005. Usos críticos y alternativas en España. Phytoma España, 161: $20-25$.

Berbegal M., García-Jiménez J., Armengol J. 2006. Evaluación de la incorporación de residuo de coliflor combinado con solarización para el control de la Verticilosis de la alcachofa en la Comunidad Valenciana. Phytoma España, 170: 30-36.

Bejarano-Alcázar J. 2004a. Efecto de la biofumigación con pasto del Sudán y colza sobre el control de Verticillum dahliae en viveros de olivo . Libro de resúmenes del XII congreso de la SEF. Lloret de Mar, Girona, 26 septiembre-1 octubre 2004. p. 283.

Bejarano-Alcázar J. 2004b. Eficacia de la solarización del suelo para la erradicación de Verticillium dahliae en viveros de olivo. Libro de resúmenes del XII congreso de la SEF. Lloret de Mar, Girona, 26 septiembre-1 octubre 2004. p. 284.

Benlioglu S., Boz Ö., Yildiz A., Kaskavalci G., Benlioglu K. 2005. Alternative soil solarization treatments for the control of soil-borne diseases and weeds of strawberry in the western Anatolia of Turkey. Journal of Phytopathology 153: 423430. 
Berger F., Hong Li , White D., Frazer R., Leifert C. 1996. Effect of pathogen inoculum, antagonist density, and plant species on biological control of Phytophthora and Pythium damping-off by Bacillus subtilis Cot 1 in high-humedity fogging glasshouses. Phytopathology 86: 428-433.

Biosca E.G., Peñalver R., Marco-Noales E., López M. 2003. Resumen de detección de bacterias fitopatógenas del suelo: Agrobacterium tumefaciens y Ralstonia solanacearum biovar 2. Phytoma España 149: 18-23.

Blok W., Lamers J.G., Termorshuizen A.J., Bollen G.J. 2000. Control of soilborne plant pathogens by incorporating fresh organic amendments followed by tarping. Phytopathology 90: 253-259.

Boer M., Sluis I., Loon L., Bakker P. 1999. Combining fluorescent Pseudomonas spp. strains to enhance supresión of fusarium wilt of radish. Eur.J. Plant Pathol 105: 201-210.

Boix A., Santos M., Diánez F., De Cara M., Martínez R.E., Gámez I., Blanco R., Tello J. 2004. Efecto de la biofumigación sobre Fusarium oxysporum f.sp. radicis cucumerinum. Comunicaciones del VI congreso de la SEAE. Almería, 27 Septiembre-2 Octubre, 2004. pp. 361-370.

Bolívar J.M. 1998. Investigaciones en España en busca de alternativas al bromuro de metilo en los cultivos. Phytoma España 101: 38-46.

Bolívar J.M. 2002. Spanish national project to find alternatives to methyl bromide. The remaining challenges. Proceedings of international conference on alternatives to methyl bromide. Sevilla, Spain 5-8 Marzo 2002. pp. 335-337.

Boudazin G., Le Roux A.C., Josi K., Labarre P., Jouan B. 1999. Design of division specific primers of Ralstonia solanacearum and application to the identification of European isolates. European Journal of Plant Pathology 105: 373380 .

Broadbent F.E. 1947. Nitrogen release and carbon loss from soil organic matter during the decomposition of added plant residues, Soil Sci. Soc. Amer. Proc., 12. pp. 246-249.

Broadbent P., Baker K.F., Frans N., Holland J. 1977. Effect of Bacillus spp. on increased growth of seedling in steamed and in non treated soil. Phytopathology 67, 1027-1034. 
Buddenhagen I.W., Kelman A. 1964. Biological and physiological aspects of bacterial wilt caused by Pseudomonas solanacearum. Annu. Rev. Phytopathol. 2: 203-230.

Bujold I., Paulitz T.C., Carisse O. 2001. Effect of Microsphaeropsis sp. On the production of perithecia and ascospores of Gibberella zeae. Plant Disease 85: 977984.

Burr T.J., Schroth M.N., Suslow T. 1978. Increased potato yields by treatment of seed pieces with specific strains of Pseudomonas fluorescens and P. putida. Phytopathology 68: 1377-83.

Butler M.J., Gardiner R.B., Day A.W. 2005. Degradation of melanin or inhibition of its synthesis: are these a significant approach as a biological control of phytopathogenic fungi? Biological Control 32, 326-336.

Camacho Ferre, F. 2004. Diferentes alternativas a la gestión de biomasa procedente de residuos vegetales. Comunicaciones del VI congreso de la SEAE. Almería, 27 Septiembre-2 Octubre, 2004. pp. 13-28.

Campbell R., Clor A. 1985. Soil moisture affects the interaction between Gaeumannomyces graminis var. tritici and antagonistic bacteria. Soil Biol. Biochem. 17: 441-446.

Candole B.L., Rothrock C.S. 1997. Characterization of the suppressivenees of hairy vetch-amended soils to Thielaviopsis basicola. Phytopathology 87, 197-202.

Carisse O., Philion V., Rolland D., Bernier J. 2000. Effect of fall application of fungal antagonists on spring ascospore production of the apple scab pathogen, Venturia inaequalis. Phytopathology 90: 31-37.

Carisse O., El Bassam S., Benhamou N. 2001. Effect of Microsphaeropsis sp. strain P130A on germination and production of sclerotia of Rhizoctonia solani and interaction between the antagonist and the pathogen. Phytopathology 91: 782-791.

Carisse O., Bernier J. 2002. Effect of environmental factors on growth, pycnidial production and spore germination of Microsphaeropsis isolates with biocontrol potential against apple scab. Mycologycal Research 106: 1455-1462.

Carisse O., Rolland D. 2004. Effect of timing of application of the biological control agent Microsphaeropsis achracea on the production and ejection pattern of ascospores by Venturia inaequalis. Phytopathology 94: 1305-134. 
Carisse O., Rolland D., Tremblay D.M. 2006. Effect of Microsphaeropsis ochracea on production of sclerotia-borne and airborne conidia of Botrytis squamosa. BioContro 51, 107-126.

Carlton W.M., Braun E.J., Gleason M.L. 1998. Entry of Clavibacter michiganensis subsp. michiganensis into tomato leaves through hydathodes. Phytopathology 88, 525-529.

Caruso P. 2005. Detección y caracterización serológica y molecular de Ralstonia solanacearum biovar 2, causante de la marchitez y podredumbre parda en patata. Tesis doctoral. Departamento de Genética. Facultad de Ciencias Biológicas. Universidad de Valencia. 215pp.

Cebolla V. 1998. Reducción de dosis y de emisiones de bromuro de metilo en la desinfección del suelo mediante plásticos VIF. Phytoma España, 101: 42-46.

Cebolla V., Bartual R., Giner A., Busto J., Pomares F., Zaragoza S., Tuset J.J., Caballero P., Mut M., Cases B., de Miguel M.D., Fombuena P., Maroto J.V., Porcuna J.L. 1999. Chemical and non chemical alternatives to methyl bromide in the area of Valencia. $3^{\text {rd }}$ International Workshop "Alternatives to Methyl Bromide for the Southern European Countries" 7-10 de diciembre , Heraclion, Creta (Grecia), 141-145.

Cebolla V., Gómez M., Roselló-Oltra J., Pomares F., Ramos C. 2004. Eficacia de la solarización y contaminación por nitratos tras la aportación de estiércol. Comunicaciones del VI Congreso SEAE. Almería 27 septiembre-2 octubre, 2004. pp. 411-418.

Cebolla V., Maroto J.V. 2005. La solarización con restos de Brasica spp. vs. bromuro de metilo y otros fumigantes químicos para desinfectar el suelo. Phytoma 172: 66-70.

Cenis J.L. 1991. Control de hongos del suelo mediante solarización. Phytoma España 30: 59-61.

Chang R.J., Ries S.M., Pataky J.K. 1990 Overwintering of Clavibacter michiganensis subsp. michiganensis and spread on alternative hosts and non-host plants.(Abstr). Phytopathology 80: 1071.

Chang R.J., Ries S.M., Pataky J.K. 1991. Dissemination of Clavibacter michiganensis subsp. michiganensis by practises used to produce tomato plants. Phytopathology 81: 1276-1281. 
Chang R.J., Ries S.M., Pataky J.K. 1992. Local tresources of Clavibacter michiganensis subsp. michiganensis in the development of bacterial canker on tomatoes. Phytopathology 82:553-556.

Chattopadhyay S.B., Mustafee T.P. 1978. Influence of organic amendments on the growth of soil-inhabiting fungal pathogens. Indian J. Microbiology 18: 69-70.

Chellemi D.O., Olson S.M., Mitchell D.J. 1994. Effects of soil solarization and fumigation on survival of soilborne pathogens of tomato in Northern Florida. Plant Disease 78: 1167-1172.

Chellemi D.O., Olson S.M., Mitchell D.J., Secker I., McSorley R. 1997. Adaptation of soil solarization to the integrated management of soilborne pests of tomato under humid conditions. Phytopathology 87: 250-258.

Chen C., Wu S. 1998. The influence of relative humidity on the adsorption of toluene by soils. Interpretation with the adsorption energy distribution functions. Chemosphere 37: 1437-1444.

Chen Y., Katan, J. 1980. Effect of solar heating of soils by transparent polyethilene mulching on their chemical properties. Soil Science. 130: 271-277.

Chen W.Y., Echandi E. 1982. Bacteriocin production and semiselective medium for detection, isolation, and quantification of Pseudomonas solanacearum in soil. Phytopathology 72: 310-313.

Chiu C., Lin T., Young C. 2003. Short-term sorption of toluene vapor onto natural organic materials. Water, Air, and Soil Pollution 144: 223-241.

Chun D., Lockwood J.L. 1985. Reductions of Pythium ultimum, Thielaviopsis basicicola, and Macrophomina phaseolina populations in soil associated with ammonia generated from urea. Plant Disease 69, 154-158.

Climent M.D., Abad M., Aragón P. 1996. El compost de residuos sólidos urbanos (R.S.U.). Sus características y aprovechamiento en agricultura. Ed. Diputació de València, Universidad Politécnica de Valencia. 187pp.

Coiduras P., Martínez A., Díaz M., Fernández-Rodríguez E.J., CamachoFerre F., Porcuna J.L. 2004. Efecto sobre la producción de tomate en cultivo ecológico en invernadero de la aplicación al suelo de distintas dosis de restos orgánicos para biofumigación o biosolarización. Comunicaciones del VI congreso de la SEAE. Almería, 27 septiembre-2 octubre, 2004. pp. 1083-1092. 
Colwell R., Brayton P.R., Grimes D.J., Roszak D.B., Huq S.A., Palmer L.M. 1985. Viable-but-noculturable Vibrio cholerae and related pathogens in the environment: implications for release of genetically engineered microorganisms. BioTechnol. 3: 817-820.

Comisión Europea. 2008. Diario Oficial de la Unión Europea: decisión de la comisión

http://eur-

lex.europa.eu/LexUriServ/LexUriServ.do?uri=OJ:L:2008:109:0032:0034:ES:PDF

21.7.08

Conn K.L., Lazarovits G. 2000. Soil factors influencing the efficacy of liquid swine manure added to soil to kill Verticillium dahliae. Can. J. Plant Pathol. 22: 400-406.

Conner R.L., Decklerck-Floate R.A., Legget F.L., Bisset J.D., Kozub G.C. 2000. Impact of a disease and a defoliating insect on houndstongue (Cynoglossum officinale) growth: implications for weed biological control. Ann. Appl. Biol. 136, 297-305.

Cook R.J. 1986. Plant health and the sustainability of agriculture with special reference to disease control by beneficial microorganisms. Biol. Agric. Hort. 3: 211-232.

Cook R.J., Baker K.F. 1983. The nature and practice of biological control of plant pathogens. American Phytopathologycal Society, St. Paul, MN. 539pp.

Daly P., Tomkins B. 1995. Production and postharvest handling of Chinese cabbage (Brassica rapa var. Pekinensis). RIRDC Publication N0. 97/1. 39 pp.

www.rirdc.gov.au/reports/AFO/chinessecabbage.doc 24.9.07

Davi L.R., Ramamatha Menon M., Aiyer R.S. 1981. Survival of Pseudomonas solanacearum in soil. Plant and Soil 62: 160-182.

Davis J.R., Huisman O.C., Westermann D.T., Hafez S.L., Everson D.O., Sorensen L.H., Schneider A.T. 1996. Effects of green manures on Verticillium wilt of potato. Phytopathology 86- 444-453.

De Cal A., Melgarejo P., Martínez-Treceño A., López-Aranda J.M. 2004. Alternativas químicas al bromuro de metilo en viveros de fresa en España. Phytoma España, 161: 14-19.

De Cara M., Tello J., Sánchez J.A. 2004. Patógenos de origen telúrico que están presentes en los cultivos sin suelo. Phytoma-España 158: 34-44. 
De León L., Rodríguez A., López M.M., Siverio F. 2006. Comparación de la separación inmunomagnética con técnicas serológicas, moleculares y de aislamiento para la detección de Clavibacter michiganensis subsp. michiganensis en semillas de tomate. Libro de resúmenes del XIII congreso de la SEF. Murcia, 18-22 septiembre 2006. p. 110.

De León L., Siverio F., López M.M., Rodríguez A. 2008. Comparative efficiency of chemical compounds for in vivo and in vitro activity against Clavibacter michiganensis subsp. michiganensis, the causal agent of tomato bacterial canker. Crop Protection 27: 1277-1283.

Deacon J.W., Berry L.A. 1993. Biocontrol of soil-borne plant pathogens: concepts and their application. Pesticides Science 37: 417-423.

Deberdt P., Queneherve P., Darrase A., Prior P. 1999. Increased susceptibility to bacterial wilt in tomato by nematode galling and the role of the $M i$ gene in resistance to nematodes and bacterial wilt . Plant pathology 48: 408-414.

DePasquale D.A., Montville T.J. 1990. Mechanism by which ammonium bicarbonate and ammonium sulfate inhibit mycotoxigenic fungi. Applied and Environmental Micribiology 56, 3711-3717.

Dhanvantari B.N. 1987. Comparison of selective media for isolation of Clavibacter michiganense pv. michiganense. (Abstr.) Phytopathology 77: 1694.

Diánez F. 2005. Evaluación de la capacidad supresora de la microbiota bacteriana y fúngica del compost de orujo de vid frente a hongos fitopatógenos. Tesis doctoral. Departamento de producción vegetal. Universidad de Almería. 276 pp.

Díaz M.E., Villa P., Frías A. 2002. Evaluation of the siderophores production by Pseudomonas aeruginosa PSS. Revista Latinoamericana de Microbiología 44: 112117.

Díaz Hernández S., Rodríguez Pérez A., Domínguez Correa P., Alcoverro T., Gallo L. 2002. Solarización: un tratamiento físico de desinfección de suelo que incrementa la producción de cultivo de tomate. Comunicaciones del V congreso de la SEAE. Gijón, 16-21 septiembre, 2002. p. 1027.

Díaz-Hernández S., Gallo L., Domínguez-Correa P., Rodríguez-Pérez A. 2004. Efecto a largo plazo de la solarización sobre la producción, incidencia de raíces corchosas y actividad biológica del suelo en el cultivo del tomate. Libro de resúmenes del XII congreso de la SEF. Lloret de Mar, Girona, 26 septiembre-1 octubre 2004. p. 289. 
Díaz-Hernández S., Gallo-Llobet L., Rodríguez-Pérez A. 2006. Evaluación de la solarización, agentes de biocontrol y biofumigación con brasicas para el control de Pyrenochaeta lycopersici en tomate. Libro de resúmenes del XIII congreso de la SEF. Murcia, 18-22 septiembre 2006. p. 110.

Díez-Rojo M.A., Bello A., García-Álvarez A., Escuer M., Sinobas J. 2002. Alternativas no químicas y control de nematodos en cultivos de Castilla y León. Comunicaciones del V congreso de la SEAE. Gijón, 16-21 septiembre, 2002. pp. 1079-1089.

Dittapongpitch V., Surat S. 2003. Detection of $R$. solanacearum in soil and weeds from commercial tomato fields using Inmunocapture and the Polimerase Chain Reaction. Journal of Phytopathology 151: 239-246.

Duniway J.M. 2002. Status of chemical alternatives to methyl bromide for preplant fumigation of soil. Phytopathology 92: 1337-1343.

Dupler M., Baker R. 1984. Survival of Pseudomonads putida, a biological control agent in soil. Phytopathology 74: 195-200.

Dutta B.K., Isaac I. 1979. Effects of organic amendments to soil on the rhizosphere microflora of antirrhinum infected with Verticillium dahliae Kleb. Plant and soil 53: 99-103.

Echandi E. 1971. Survival of Corynebacterium michiganense in soil as free cells and in infected tomato tissue. Phytopathology 61: 890-891.

Edwards U., Rogall T., Blöcker H., Emde M., Böttger E.C. 1989. Isolation and direct complete nucleotide determination of entire genes. Characterization of a gene coding for 16S ribisomal RNA. Nucleic Acids Res 17: 7843-7857.

Edwards S., Seddon B. 2001. Mode of antagonism of Brevibacillus brevis against Botrytis cinerea in vitro. Journal of Applied Microbiology 91: 652-659.

El Bassam S., Benhamou N., Carisse O. 2002. The role of melanin in the antagonistic interaction between the apple scab pathogen Venturia inaequalis and Microsphaeropsis ochracea. Can. J. Microbiol. 48: 349-358.

El Hadiri N., Ammati M., Chgoura M., Mounir K. 2003. Behaviour of 1,3dichloropropene and methyl isothiocyanate in undisturbed soil columns. Chemosphere 52: 893-899. 
Elad Y, Katan J, Chet I. 1980. Physical, biological, and chemical control integrated for soilborne diseases in potatoes. Phytopathology 70: 418-422.

Elorrieta M.A., González J.M., López O., Urrutia M.T., Aguilar M.I., Gómez R., Gómez V.M. 2006. Persistencia de Clavibacter michiganensis subsp. michiganensis en raíces de tomate. Libro de resúmenes del XIII congreso de la SEF. Murcia, 18-22 septiembre 2006. p. 340.

El-Tarabily K.A., Soliman M.H., Nassar A.H., Al-Hassani H.A., Sivasithamparam K., McKenna F., Ardí G. 2000. Biological control of Sclerotinia minor using a chitinolytic bacterium and actinomycetes. Plant Pathology 49: 573-583.

Enfinger J.M., McCarter S.M., Jaworski C.A. 1979. Evaluation of chemicals and application methods for control of bacterial wilt of tomato transplants. Phytopathology 69: 637-640.

Escobar A. 1997. Residuos generados por la actividad productiva. Medidas respetuosas con el medio ambiente. En: Actualización de temas sobre la horticultura almeriense. Ed. Isabel $\mathrm{M}^{\mathrm{a}}$ Cuadrado Gómez y Luis Fernández Fernández pp. 51-82.

Fatmi M., Schaad N.W. 1985. A semiselective medium for isolation of Corynebacterium michiganensec subsp. michiganense. (Abstr.) Phytopathology 75: 1332.

Fatmi M., Schaad N.W. 1988. Semiselective agar medium for isolation of Clavibacter michiganense subsp. michiganense from tomato seed. Phytopathology 78: 121-126.

Fatmi M., Schaad N.W. 2002. Survival of Clavibacter michiganensis ssp. michiganensis in infected tomato stems under natural field conditions in California, Ohio and Morocco. Plant Pathology 51: 149-154.

Fellows H. 1929. Studies of certain soil phases of the wheat take-all problem (Abstr.) Phytopathology 19:103.

Flores P., Hellín P., Lacasa A., Fernández P., Ruiz M., Marin C., Fenoll J. 2006. Estudio de la acumulación de metales pesados en suelo después de sucesivas desinfecciones con biofumigación + solarización. Libro de resúmenes del VII Congreso de la SEAE . Zaragoza,18-23 Septiembre 2006, p. 109. 
Flavier A.B., Ganova-Raeva L.M., Schell M., Denny T. 1997. Hierarchical autoinduction in Ralstonia solanacearum: control of acyl-homoserine lactone production by a novel autoregulatory system responsive to 3-hydroxypalmitic acid methyl ester. J. Bacteriol. 179: 7089-7097.

Földes T., Banhegyi I., Varga Z., Szageti J. 2000. Isolation of Bacillus strains from the rhizosphere of cereals and in vitro screening for antagonism against phytopathogenic, food-borne pathogenic and epoilage microorganisms. Journal of Applied Microbiology 89: 840-845.

Francés J., Bonaterra A., Moreno M.C., Cabrefiga J., Badosa E., Montesinos E. 2006. Agresividad del patógeno y eficacia del biocontrol de podredumbres fúngicas en postcosecha mediante Pantoea agglomerans. Libro de resúmenes del XIII congreso de la SEF. Murcia, 18-22 septiembre 2006. p. 137.

French E.B., Gutarra L., Aley P., Elphinstone J. 1995. Culture media for Ralstonia solanacearum. Isolation, identification and maintenance. Fitopatología 30: 126-130.

http://www.cipotato.org/Training/Materials/Bacterial/Bacterial8.PDF 20-8-08

Galal A.A., Kehil Y.E..I., El-Daoudi Y.H., Shihata Z.A., Ouf M.F. 2003. A comparative study on the identification of races and biovars of some Egyptian isolates of $R$. solanacearum. Egyptian Journal of Phytopathology 31: 103-117.

Gamliel A., Hadar E., Katan J. 1989. Soil solarization to improve yield of gypsophila in monoculture systems. Acta Horticulturae (Belgium) 255: 131-138.

Gamliel A., Katan J. 1991. Involvement of fluorescent pseudomonads and other microorganism in increased growth response of plants in solarized soils. Phytopathology 81: 494-502.

Gamliel A., Katan J. 1992. Influence of seed and root exudates on fluorescent peudomonads and fungi in solarized soil. Phytopathology 82: 320-327.

Gambiel A., Katan J. 1993. Suppression of major and minor pathogens by fluorescent pseudomonads in solarized and nonsolarized soils. Phytopathology 83: 68-75.

Gambiel A., Stapleton J.J. 1993. Characterization of antifungal volatile compounds evolved from solarized soil amended with cabbage residues. Phytopathology 83: 899-905.

Gamliel A., Austerweil M., Kritzman G. 2000. Non-chemical approach to soilborne pest management-organic amendments. Cop Prot. 19:847-853. 
Garbeva P., van Veen J., van Elsas J. 2003. Predominant Bacillus spp. In agricultural soil under different management regimes detected via PCR-DGGE. Microbial Ecology 43: 302-316.

García-Álvarez A., Bello A. 2004. Diversidad de los organismos de suelo y transformaciones de la materia orgánica. En: Agrícola Española (Eds.). Conference book, I Internacional Conference on Soil and Compost Eco-Biology, 15-17 September 2004, León, España. Pp. 211-212.

García-Álvarez A., Díez-Rojo M.A., López-Pérez J.A., Bello A. 2004. Materia orgánica, biofumigación y manejo de organismos del suelo patógenos de los vegetales. En: Labrador J. (Ed): Conocimientos, técnicas y productos para la agricultura y la ganadería ecológica. SEAE, Valencia, pp.71-76.

García-Gutiérrez L., Romero D., Codina J.C., De Vicente A., Pérez-García A. 2006. Aislamiento y selección de rizobacterias promotoras de crecimiento e inductoras de resistencia sistémica en melón. Libro de resúmenes del XIII congreso de la SEF. Murcia, 18-22 septiembre 2006. p. 106.

García-Izquierdo C., Hernández T. 2004. Importancia de la medida de la actividad microbiana en suelos y materiales orgánicos. En: Agrícola Española (Eds.). Conference book, I Internacional Conference on Soil and Compost EcoBiology, 15-17 September 2004, León, España. Pp. 209-210

Gerlagh M., Goosen-van de Geijn H.M., Fokkema N.J., Vereijken P.F.G. 1999. Long-term biosanitation by application of Coniothyrium minitans on Sclerotinia sclerotiorum-infected crops. Phytopathology 89, 141-147.

Gilpatrick J.D. 1969. Role of ammonia in the control of avocado root rot with alfalfa meal soil amendment. Phytopathology 59: 973-978.

Gimsing A.L., Poulsen J.L., Pedersen H.L., Bruun-Hansen H.C. 2007. Formation and degradation kinetics of the biofumigant benzyl isothiocyanate in soil. Environ. Sci. Technol. 41: 4271-4276.

Girish N., Umesha S. 2005. Effect of plant growth promoting rhizobacteria on bacterial canker of tomato. Archives of phytopathology and plant protection 38: 235-243.

Gitaitis R.D. 1990. Induction of a hypersensitivelike reaction in four-o'clock by Clavibacter michiganensis subsp. michiganensis. Plant Dis. 74: 58-60. 
Gitaitis R.D., Leben C. 1988. Detection of Clavibacter michiganensis subsp. michiganensis in latent infections of tomato (Abstr.). Phytopathology 78: 1551.

Gitaitis R.D., Beaver R.W. 1990. Characterization of faffty acid methyl ester content of Clavibacter michiganensis subsp. michiganensis. Phytopathology 80: 318-321.

Gitaitis R.D., Beaver R.W., Voloudakis A.E. 1991. Detection of Clavibacter michiganensis subsp. michiganensis in symptomless tomato transplants. Plant Disease 75: 834-838.

Gleason M.L., Braun E.J. 1988. Survival and distribution of epiphytic populations of Clavibacter michiganense subs. michiganense on tomato foliage and fruit. (Abstr.) Phytopathology 78: 1565.

Gleason M.L., Braun E.J., Carlton W.M. 1990. Survival and spread of Clavibacter michiganensis subsp. michiganensis in tomatoes. (Abstr.) Phytopathology 80: 1030.

Gleason M.L., Braun E.J., Carlton W.M., Peterson R.H. 1991. Survival and dissemination of Clavibacter michiganensis subs. michiganensi in tomatoes. Phytopathology 81: 1519-1523.

Gómez V.M., González J.M., López O., Urrutia M.T., Aguilar M.I., Gómez R., Elorrieta M.A. 2006. Capacidad infectiva de Clavibacter michiganensis spp. michiganensis en raíces de tomate. Libro de resúmenes del XIII congreso de la SEF. Murcia, 18-22 septiembre 2006. p. 341.

González R., Montealegre J., Herrera R. 2004. Control biológico de Fusarium solani en tomate mediante el empleo de los antagonistas Paenibacillus lentimorbus y Trichoderma spp. Ciencia e Investigación Agraria 31: 21-28.

González-Sánchez M.A., Cazorla F.M., Ramos C., De Vicente A., PérezJiménez R.M. 2006. Especies de Pseudomonas y Bacillus aisladas de suelos de raíces de aguacate para su aplicación en el biocontrol de Rosellinia necatrix. Libro de resúmenes del XIII congreso de la SEF. Murcia, 18-22 septiembre 2006. p. 154.

Gorissen A., van Overbeek L.S., van Elsas J.D. 2004. Pig slurry reduces the survival of Ralstonia solanacearum biovar 2 in soil. Canadian Journal of Microbiology 50: 587-593.

Götz M., Zornbach W., Boyle C. 1993. Life cycle of Mycosphaerella brassicicola (Duby) Lindau and ascospore production in vitro. Journal of Pathology 139: 298-308. 
Graham J., Lloyd B. 1978. An improved indicator plant method for the detection of Pseudomonas solanacearum race 3 in soil. Plant Disease Reporter 62: 35-37.

Graham J., Lloyd B. 1979. Survival of potato strain (race 3) of Pseudomonas solanacearum in the deeper soil layers.. Aust. J. Agric. 30: 489-496.

Granada G.A., Sequeira L. 1981. Survival of Pseudomonas solanacearum in presumed non-host plantas: a new concept. En International conference on plan pathogenic bacteria, $5^{\text {th }}$; Cali, Colombia, 1981. Proceedings edited by Lozano J.C. Centro Internacional de Agricultura Tropical. p.123.

Greenberger A., Yogev A., Katan J. 1987. Induced suppressiviness in solarized soils. Phytopathology 77: 1663-1667.

Grey B.E., Steck T.R. 2001. The viable but nonculturable state of Ralstonia solanacearum may be involved in long-therm survival and plant infection. Appl. Environ. Microbiol. 67: 3866-3872.

Guerrero M.M., Lacasa A., Ros C., Guirao P., Bello A., López J.A., Martínez M.C., Martínez M.A., Barceló N. 2002. Biofumigation with solarization for soil disinfection and sustainable production of greenhouse-grown sweet pepper in the Southeast of Spain. Proceedings of international conference on alternatives to methyl bromide. Sevilla, Spain 5-8 Marzo 2002. pp. 341.

Guerrero M.M., LacasaA., Ros C., Bello A., Martínez M.C., Torres J., Fernández P. 2004. Efecto de la biofumigaciónn con solarización sobre los hongos del suelo y la producción: fechas de desinfección y enmiendas. En: A. Lacasa, M.M. Guerrero, M. Oncina, J.A. Mora (Eds). Desinfección de suelos en invernaderos de pimiento. Publicaciones de la consejería de Agricultura, Agua y Medio Ambiente. Región de Murcia. Jornadas 16, 209-238.

Guerrero M.M., Ros C., Martínez M.A., Torres J., Martínez M.C., Bielza P., Contreras J., Lacasa A. 2006a. Uso reiterado de 1,3-Dicloropropeno y cloropicrina en la desinfección de suelos de invernadero de pimiento. Libro de resúmenes del XIII congreso de la SEF. Murcia, 18-22 septiembre 2006. p. 372.

Guerrero M.M., Martínez M.A., Ros C., Martínez M.C., Bello A., Lacasa A. 2006b. Biosolarización y biofumigación para la producción de pimiento ecológico en invernadero CD de comunicaciones del VII Congreso de la SEAE. 18-23 septiembre 2006, Zaragoza No 103. 
Gullino M.L. 2000. Status of methyl bromide alternatives for soil fumigation in Southern Europe. In: Methyl bromide alternatives for North African ans Southern European countries. Eds. UNEP, pp. 87-92.

Gullino M.L., Camponogara A., Gasparrini G., Rizzo V., Clini C., Garibaldi A. 2003. Replacing methyl bromide for soil disinfestation. The italian experience and implications for other countries. Plant Disease, 87: 1012-1021.

Hagen C.A., Hawrylewicz E.J., Anderson B.T., Tolkacz V.K., Cephus M.L. 1968. Use of the scanning electron microscope for viewing bacteria in soil. Appl. Microbiol. 16: 932-934.

Hayward A.C. 1964. Characteristics of Pseudomonas solanacearum. J. Appl. Bacteriol. 27:265-277.

Hayward A.C. 1991. Biology and epidemiology of bacterial wilt caused by Pseudomonas solanacearum. Annu. Rev. Phytopathol. 29: 65-89.

Hayward A.C., El-Nashaar H.M., Nydegger U., De Lindo L. 1990. Variation in nitrate metabolism in biovars of Pseudomonas solanacearum. J. Appl. Bacteriol. 69: 269-280.

Haywood A.C. 1991. Biology and epidemiology of Bacterial Wilt caused by Pseudomonas solanacearum. Ann. Rev. Phytopathol. 29: 65-87.

He L.Y., Sequeira L.L., Kelman A. 1983. Characteristics of strains of Pseudomonas solanacearum from China. Plant Dis. 67:1357-1361.

Hoitink H.A.J., Fahy P.C. 1986. Basis for the control of soilborne plant pathogens with compost. Annual Review of Phytopathology 24: 93-114.

Hoitink H.A.J., Boehm M.J. 1999. Biocontrol within the context of soil microbial communities: a substrate-dependent phenomenon. Ann. Rev. Phytopathol, 37: 427446.

Horita M., Tsuchiya K. 2001. Genetic diversity of Japanese strains of $R$. solanacearum. Phytopathology 91:399-407.

Huang J. 1986. Ultraestructure of bacterial penetration in plants. Ann. Rev. Phytopathol. 24: 141-157.

Huber D.M., Watson R.D. 1970. Effect of organic amendment on soil-borne plant pathogens. Phytopathology 60: 22,26. 
Huber D.M., Anderson G.R. 1976. Effect of organic residues on snowmold of winter wheat. Phytopathology 66: 1028-1032.

Islam T.M.D., Toyota K. 2004. Suppression of bacterial wilt of tomato by $R$. solanacearum by incorporation of compost in soil and possible mechanisms. Microb. Environ. 19: 53-60.

Islas-Flores I., Peraza-Echevarría L., Canto-Canché B., Rodríguez-García C.M. 2006. Extraction of high-quality, melanin-free RNA from Mycosphaerella fijiensis for cDNA preparation. Molecular Biotechnology 34: 45-50.

Jackson M.T., González L.C. 1981. Persistence of Pseudomonas solanacearum (race 1) in naturally infested soil in Costa Rica. Phytopathology 71: 690-693.

Jacobsen B.J., Backman P.A. 1993. Biological and cultural plant disease controls: alternatives and supplements to chemicals in IPM systems. Plant disease 77: 311-315.

Jahr H., Bahro R., Burger A., Ahlemeyer J., Eichenlaub R. 1999. Interactions between Clavibacter michiganensis and its host plants. Environmental Microbiology 1: 113-118.

Ji P., Momol M.T., Olson S.M., Pradhanang P.M. 2005. Evaluation of thymol as biofumigant for control of bacterial wilt of tomato under field conditions. Plant Disease 89: 497-500.

Johnson A.W., A.W., Golden A.M., Auld D.L., Summer D.R. 1992. Effects of rapessed and vetch as green manure crops and fallow on nematodes and soliborne pathogens. J. Nematol. 24: 117-126.

Jones J.B., Jones J.P., Stall R.E., Zitter T.A. 1991. Compendium of tomate diseases. American Phytopathological Society, University of Florida, 73pp.

Jones E.E., Mead A., Whipps J.M. 2004. Effect of inoculum type and timing of application of Coniothyrium mimitans on Sclerotinia sclerotiorum: control of sclerotinia disease in glasshouse lettuce. Plant Pathology 53: 611-620.

Jordan V.W.L., Sneh B., Eddy B.P. 1972. Influence of organic amendments on Verticillium dahliae and on the microbial composition of the strawberry rhizosphere. Annals of Applied Biology 70: 139-148.

Justo de Oliveira E., Rabinovitch L., Gomes R., Konovaloff L., Zahner V. 2004. Molecular characterization of Brevibacillus laterosporus and its potential use in biological control. Applied and Environmental Microbiology 70: 6657-6664. 
Kado C.I., Heskett M.G. 1970. Selective media for isolation of Agrobacterium, Corynebacterium, Erwinia, Pseudomonas y Xanthomonas. Phytopathology 60: 969-976.

Kang Y., Saile E., Schell M.A., Denny T.P. 1999. Quantitative immunofluorescence of regulated eps gene expression in single cells of Ralstonia solanacearum. Applied and Environmental Microbiology 65: 2356-2362.

Kaplan M., Noe J.P. 1993. Effect of chicken-excrement amendments on Meloydogyne arenaria. Journal of Nematology 25: 71-77.

Katan J. 1980. Solar pasteurization of soils for disease control; status and prospects. Plant Disease 64: 450-454.

Katan J. 1981. Solar heating (solarization) of soil for control of soilborne pests. Annual Review of Phytopathology 19: 211-236.

Katan J., Greenberger A., Alon H., Grinstein A. 1976. Solar heating by polyethylene mulching for the control of diseases caused by soilborne pathogens. Phytopathology 66: 683-688.

Katan J., Fishler G., Grinstein A. 1983. Short- and Long-term effects of soil solarization and crop sequence on fusarium wilt and yield of cotton in Israel. Phytopathology 73: 1215-1219.

Karganilla A.D., Buddenhagen I.W. 1972. Development of a selective medium for Pseudomonas solanacearum. Phytopathology 62: 1373-1376.

Keinath A.P. 1996. Soil amendment with cabbage residue and crop rotation to reduce gummy stem bligth and increase growth and yield of watermelon. Plant Disease 80: 564-570.

Kelman A. 1954. The relationship of pathogenicity in Pseudomonas solanacearum to colony appearance on tetrazolium media. Phytopathology 44: 693-695.

Kennedy R., Wakeham A.J., Cullington J.E. 1999. Production and immunodetection of ascospores of Mycosphaerella brassicicola: ringspot of vegetable crucifers. Plant Pathology 48, 297-307.

Kennedy R., Wakeham A.J., Byrne K.G., Meyer U.M., Dewey F.M. 2000. A new method to monitor airborne inoculum of the fungal plant pathogens Mycosphaerella brassicicola y Botrytis cinerea. Applied and Environmental Microbiology 66: 2996-3003. 
Khlaif H. 2003. Effect of soil solarization on total Agrobacterium spp. population, inoculated Agrobacterium tumefaciens, and on the development of crown gall. Journal of Plant Pathology 85: 117-122.

Kim Y.S., Kil B.S. 2001. Allelopathic effects of some volatile substances from the tomato plant. Journal of crop production, 4: 313-321.

Kirkegaard J.A., Gardner P.A., Desmarchelier J.M., Angus J.F. 1993. Biofumigation-using Brassica species to control pests and diseases in horticulture and agriculture. In: Proceedings $9^{\text {th }}$ Australian Research Assembly on Brassicas. Pp.77-82.

Kirkegaard J.A., Mathiessen J.N. 2004. Developing and refining the biofumigation concept. Agroindustria 3: 233-239.

Klement Z., Farkas G.L., Lovrekovich L. 1964. Hypersensitive reaction induced by phytopathogenic bacteria in the tobacco leaf. Phytopathology 54: 474-477.

Kloepper J.W. 1998. Biological control an alternative to methyl bromide. En: A. Bello, J.A. González, M. Arias, R. Rodríguez-Kábana (Eds). Alternatives to Methyl Bromide for the Southern European Countries. DG XI EU, CSIC, Valencia, 245-249.

Kloepper J. W., Schroth M.N. 1981. Relationship of in vitro antibiosis of plant growth-promoting rhizobacteria to plant growth and displacement of root microflora. Phytopathology 71: 1020-1024.

Kloepper J.W., Leong J., Teintze M., Schroth M.N. 1980a. Enhaced plant growth by siderophores produced by plant growth-promoting rhizobacteria. Nature 286: 885-886.

Kloepper J.W., Schroth M.N. and Miller T.D. 1980b. Effects of rhizosphere colonization by plant growth-promoting rhizobacteria on potato plant development and yield. Phytopathology 70: 1078-1082.

Kock I., Krohn K., Egold H., Draeger S., Schulz B., Rheinheimer J. 2007. New massarilactones, massarigenin E, and coniothyrenol, isolated from the endophytic fungus Coniothyrium sp. from Carpobrotus edulis. European Journal of Organic Chemistry 13: 2186-2190.

Köhl J., Fokkema N.J. 1998. Strategies for biological control of necrotrophic fungal foliar pathogens. In: Greg J. Boland y L. David Kuykendall (Eds.). PlantMicrobe interactions and biological control. New York, pp. 49-88. 
Köhl J., van der Plas C.H., Molhoek W.M.L., Fokkema N.J. 1995. Effect of Ulocladium atrum and other antagonists on sporulation of Botrytis cinerea on dead lily leaves exposed to field conditions. Phytopathology, 85: 393.

Krieg N.R., Holt J.G. 1984. Bergey's Manual of Systematic Bacteriology. de. Williams and Wilkins. Baltimore, USA, 964 pp.

Lacasa A., Guirao P., Guerreo M.M., Ros C., López-Pérez J.A., Bello A., Bielza P. 1999. Alternatives to methyl bromide for sweet pepper cultivation in plastic greenhouse in south east. $3^{\text {rd }}$ International Workshop "Alternatives to Mehyl Bromide for the Southern European Countries" del 7 al 10 de diciembre, Heraclion, Creta (Grecia), 133-135.

Lacasa A., Guerrero M.M., Guirao P., Ros C. 2002. Alternatives to methyl bromide in vegetable crops and strawberry crops in Spain. En: T.A. Batchelor, J.M. Bolívar (Ed.). Proceedings of the Intrnational Conference on Alternatives to Methyl Bromide. The remaining challenges. Seville, Spain, 5-8 March. European Commission, Brussels, Belgium, 172-177.

Lacasa A., Guerrero M.M., Quinto V., Lacasa C., Bielza P., Contreras J., Torné M. 2004. Eficacia del Telone C-35 en la desinfección de suelos de tomate. Libro de resúmenes del XII congreso de la SEF. Lloret de Mar, Girona, 26 septiembre-1 octubre 2004. p. 238.

Lazarovits G., Tenuta M., Conn K.L. 2001. Organic amendments as a disease control strategy for soilborne diseases of high-value agricultural crops. Australasian Plant Pathology 30: 111-117.

Lazcano C., Gómez M., Arnold J., Tato A., Domínguez J., Mato S. 2004. Compostaje y vermicompostaje de estiércol de vacuno. En: Agrícola Española (Eds.). Conference book, I Internacional Conference on Soil and Compost EcoBiology, 15-17 September 2004, León, España. p. 293.

Lazzeri L., Leoni O., Manici L.M. 2004. Biocidal plant dried pellets for biofumigation. Industrial Crops and Products 20: 59-65.

Leben C. 1981. How plant-pathogenic bacteria survive. Plant Disease 65:633-637.

Leifert C., Li H., Chidburee S., Hampson S., Workman S., Sigee D., Epton H.A.S., Harbour A. 1995. Antibiotic production and biocontrol activity by Bacillus subtilis CL27 and Bacillus pumilus CL45. J. Appl. Bacteriol., 78:97. 
Leyns F., De Cleene M. 1983. Histopathology of the bacteriosis caused by inoculation of Corynebacterium michiganense and Xanthomonas campestris pv. vesicatoria in tomato stems. Mededelingen van de Faculteit Landbouwwetenschapen, Rijkuniversiteit Gent 48: 663-670.

Lewis J.A., Papaverizas G.C. 1970. Evolution of volatile sulfur-containing compounds from decomposition of crucifers in soil. Soil biology and biochemistry 2: $239-246$.

Lewis J.A., Papaverizas G.C. 1971. Effect of sulfur-containing volatile compounds and vapors from cabbage decomposition on Aphanomyces euteiches. Phytopathology 61: 208-214.

Lewis J.A., Papaverizas G.C. 1974. Effect of volatiles from decomposing plant tissues on pigmentation, growth, and survival of Rhizoctonia solani. Soil Science 118: $156-163$.

Loper J.E., Haack C., Schroth M.N. 1985. Population dynamics of soil pseudomonads in rhizosphere of potato (Solanum tuberosum L.). Appl. Environ. Microbiol. 49: 416-422.

López A., Guirao P. 1998. El bromuro de metilo y el cultivo del pimiento en el Campo de Cartagena. Phytoma España, 101: 26-30.

López M.M., Peñalver R., Biosca E.G., Marco-Noales E. 2003. Detección de bacterias fitopatógenas del suelo: Agrobacterium tumefaciens y Ralstonia solanacearum biovar 2. Phytoma España 149: 18-24.

López-Aranda J. 1999. The Spanish national project on alternatives to methyl bromide. The network in Andalusia. $3^{\text {rd }}$. International Workshop "Alternatives to Mehyl Bromide for the Southern European Countries" del 7 al 10 de diciembre, Heraclion, Creta (Grecia), 163-166.

López-Martínez N., Catillo S., Cuaresma I.M., Carmona I., González-Zamora J.E., Avilla C., López-Medina J., Aguirre I. 2004. Efecto de la biofumigación sobre flora arvense del cultivo del fresón. Comunicaciones del VI congreso de la SEAE. Almería, 27 septiembre-2 octubre, 2004. pp. 1531-1538.

Lorezco T.M., Mariano J.S. 2003. Combined deleafinf with fungicides as control scheme for ringspot disease (Mycosphaerella brassicicola L.) of cabbage. 2001 Regional research an d development symposia, (np), Jul-Sep 2002 (2003). Available in AGRIS record:

http://www.fao.org/agris/search/display.do;jsessionid=CDA3490CA5DE3A51176

B003F98E319C6?F=./2004/v3005/PH2004000505.xml;PH2004000505 25.10.07. 
Lozano J.C., Sequeira L. 1970. Differientation of races of Pseudomonas solanacearum by a leaf infiltration technique. Phytopathology 60: 833-838.

Madigan M.T., Martinko J.H., Parker J. 1998. Biología de los microorganismos. $8^{a}$ Edición. de. Prentice Hall, Hertfordshire. 1064 pp.

Mansoori B., Jaliani N.K.H. 1996. Control of soilborne pathogens of watermelon by solar heating. Crop protection 15: 423-424.

Maroto J.V. 1990. Elementos de horticultura general. Ed. Mundi-Prensa. Madrid. $343 \mathrm{pp}$.

Martin F.N. 2003. Development of alternative strategies for management of soilborne pathogens currently controlled with methyl bromide. Ann. Rev. Phytopathol. 41:325-350.

Martín-Pérez R., Pérez-García A., De Vicente A., Cazorla F.M. 2006. Identificación de genes implicados en la producción de 2-hexyl 5-propyl resorcinol en Pseusomonas fluorescens PCL 1606 y su relación con la actividad de biocontrol. Libro de resúmenes del XIII congreso de la SEF. Murcia, 18-22 septiembre 2006. p. 107.

Martínez M.A., Lacasa A., Guerrero M.M., Ros C., Guirao P., Martínez M.C., Barceló N., Oncina M., Mello A. 2002. Desinfección del suelo mediante biofumigación con solarización en cutivos ecológicos de pimiento de invernadero. Comunicaciones del V congreso de la SEAE. Gijón, 16-21 septiembre, 2002. pp. 1015-1019.

Martínez M.A., Guerrero M.M., Martínez M.C., Barceló N., Ros C., Lacasa A., Tello J.C. 2004a. Efecto de la biofumigación con solarización sobre la microflora del suelo en cultivos de pimiento en invernadero. Libro de resúmenes del XII congreso de la SEF. Lloret de Mar, Girona, 26 septiembre-1 octubre 2004. p. 89.

Martínez M.A., Lacasa A., Guerrero M.M., Martínez M.C., Ros C., Barceló N., Tello J.C. 2004b. Variaciones en la microbiota fúngica de suelos de invernaderos de pimiento desinfectados con productos químicos. Libro de resúmenes del XII congreso de la SEF. Lloret de Mar, Girona, 26 septiembre-1 octubre 2004. p. 241. 
Martínez M.A., Ros C., Guerrero M.M., Torres J., Beltrán C., Cano A., Lacasa A. 2006a. Dimetil disulfito y cloropicrina para la desinfección de suelos de invernadero de pimiento. Libro de resúmenes del XIII congreso de la SEF. Murcia, 18-22 septiembre 2006. p. 373.

Martínez M.A., Guerrero M.M., Martínez M.C., Ros C., Lacasa A., Tello J. 2006b. Efecto de la biosolarización reiterada sobre la microbiota fúngica en cultivos de pimiento. CD de Comunicaciones del VII Congreso de la SEAE. 18-23 Septiembre 2006, Zaragoza. $\mathrm{N}^{\circ} 212$.

Martyn R.D. 1986. Use of soil solarization to control fusarium wilt of watermelon. Plant Disease 70: 762-766.

Matthiessen J.N., Warton B., Shackleton M.A. 2004. The importance of plant maceration and water addition in achieving high Brassica-derived isothioyanate levels in soil. Agroindustria 3: 277-280.

Matthiessen J.N., Shackleton M.A. 2005. Biofumigation: environmental impacts on the biological activity of diverse pure and plant-derived isothiocyanates. Pest Manag. Sci. 61: 1043-1051.

Matthiessen J.N., Kirkegaard J.A. 2006. Biofumigation and enhaced biodegradation: opportunity and challenge in soilborne pest and disease management. Critical Reviews in Plant Sciences 25: 235-265.

MBTOC. 1997. Report of the Technology and Economic Assessment Panel. UNEP, Nairobi, Kenya, 221 pp.

McCarter S.M. 1976. Persistence of Pseudomonas solanacearum in artificially infested soils. Phytopathology 66, 998-1000.

McIlveen W.D., Cole H. Jr. 1977. Influence of sewage sludge soil amendment on various biological components of the corn field ecosystem. Agric. Environ. 3: 349.362 .

McLeod R.W., Steele C.C. 1999. Effects of Brassica leaf green manures and crops on activity and reproduction of Meloidogyne javanica. Nematology 1: 613624.

McQuilken M.P., Budge S.P., Whipps J.M. 1997. Biological control of Sclerotinia sclerotiorum by film-coating Coniothyrium minitans on to sunflower seed ans sclerotia. Plant Pathology 46, 919-929. 
Melton T.A., Powell N.T. 1991. Effects of two-year crop rotations and cultivar resistance on bacterial wilt in flue-cured tobacco. Plant Disease 75: 695-698.

Mehrabi R., Kema G.H.J. 2006. Protein kinase A subunits of the ascomycete pathogen Mycosphaerella graminicola regulate asexual fructification, filamentation, melanization and osmosensing. Molecular Plant Pathology 7: 565577.

Messiaen C.M., Blancard D., Rouxel F., Lafon R. 1995. Enfermedades de las hortalizas. Ed. Mundi-Prensa. Madrid. 576 pp.

Michel V.V., Mew T.W. 1998. Effect of a soil amendment on the survival of Ralstonia solanacearum in different soils. Phytopathology 88: 300-305.

Moffet M.L., Wood B.A. 1984. Survival of Corynebacterium michiganense subs. michiganense within host-debris in soil. Australas. Plant Pathol. 13:1-3.

Montealegre J., Reyes R., Pérez L., Herrera R., Silva P., Besoain X. 2003. Selection of bioantagonistic bacteria to be used in biological control of Rhizoctonia solani in tomato.Electronic Journal of Biotechnology. Environmental Biotechnology 6, n. 2.

Mojtahedi H., Santo G.S., Wilson J.H., Hang A.N. 1993. Managing Meloidogyne chitwoodi on potato with rapeseed green manure. Plant Dis 77: 2-46.

Momol T., Jones J., Olson S. 2003. New outbreak of $R$. solanacearum (Race 3, biovar 2) in geraniums in U.S. and effects of biofumigants on $R$. solanacearum (Race 1, biovar 1). University of Florida, IFAS, NFREC, Quincy, and Plant Pathology Department, Gainesville, Florida. http://pestalert.ifas.ufl.edu/tmm0303.htm 20-8-08

Moreno M.C., Badosa E., Rodríguez-Palenzuela P., López-Solanilla E., Peñalver R., Montesinos E. 2006. Mecanismo de biocontrol de hongos patógenos de poscosecha en el biofungicida Pantoea agglomerans EPS-125. Libro de resúmenes del XIII congreso de la SEF. Murcia, 18-22 septiembre 2006. p. 77.

MPS 2005. Certificatieschema MPS ABC v5 SP 251005.doc 25-11-2006

Muehlchen A.M., Rand R.E., Parke J.L. 1990. Evaluation of green manures for controlling Aphanomyces root rot of peas. Plant. Dis. 74: 651-654.

Munnecke D.E., Ferguson J. 1960. Effect of soil fungicides upon soil-borne, plant pathogenic bacteria and soil nitrogen. Plant Dis. Reptr. 44: 552-555. 
Mycology 2008. Rhizopus sp. en:

http://www.mycology.adelaide.edu.au/Fungal_Descriptions/Zygomycets/Rhizopus/ 14-10-08

Nagarajkumar M., Jayaraj J., Muthukrishnan S., Bhaskaran R., Velazhahan R. 2005. Detoxification of oxalic acid by Pseudomonas fluorescens strain PfMDU2: implications for the biological control of rice sheath blight caused by Rhizoctonia solani. Microbiological Research 160: 291-298.

Nesmith W.C., Jenkins S.F. Jr. 1979. A selective medium for the isolation and quantification of Pseudomonas solanacearum from soil. Phytopathology 69: 182185.

Nesmith W.C., Jenkins S.F. Jr. 1983. Survival of Pseudomonas solanacearum in selected North Carolina soils. Phytopathology 73: 1300-1304.

Noble R., Roberts S.J. 2004. Eradication of plants pathogens and nematodes during composting: a review. Plant Pathology 53: 548-568.

OEPP/EPPO. 2004a. Diagnostic protocols for regulates pests. Ralstonia solanacearum. Boletín 34, 173-178.

OEPP/EPPO. 2004b. National regulatory control systems. Ralstonia solanacearum. Boletín 34, 327-329.

OEPP/EPPO. 2005. Clavibacter michiganensis subsp. michiganensis. Bulletin 35, 275-283.

OEPP/EPPO. 2006a. Map: Ralstonia solanacearum

http://www.eppo.org/QUARANTINE/bacteria/Ralstonia_solanacearum_race3/PSD MS3_map.htm 26-8-08

OEPP/EPPO. 2006b. Map: Clavibacter michiganensis subsp. michiganensis http://www.eppo.org/QUARANTINE/bacteria/Clavibacter_m_michiganensis/COR BMI_map.htm 26-8-08

Ofuya C.O., Wood R.K.S. 1981. Virulence of Pseudomonas solanacearum in relation to extracellular polysaccharides. En International conference on plan pathogenic bacteria, $5^{\text {th }}$; Cali, Colombia, 1981. Proceedings edited by Lozano J.C. Centro Internacional de Agricultura Tropical. pp. 263-269.

Ohr H.D., Sims J.J., Grech N.M., Becker J.O. 1996. Methyl Iodide, an ozonesafe alternative to methyl bromide as a soil fumigant. Plant Disease 80: 731-735. 
Pascual J.A., Navarro N., Mercader D., Fernández P., Lacasa A. 2006. Efectos de la biosolarización sobre la lixiviación de nitratos en cultivos de pimiento en invernadero. Libro de resúmenes del VII Congreso de la SEAE. 18-23 Septiembre 2006, Zaragoza, España. p. 95.

Partridge D.E., Sutton T.B., Jordan D.L., Curtis V.L., Bailey J.E. 2006. Management of Sclerotinia blight of peanut with the biological control agent Coniothyrium minitans. Plant Disease 90, 957-963.

Pfender W.F. 1988. Suppression of ascocarp formation in Pyrenophora triticirepentis by Limonomyces roseipellis, a basidiomycete from reduced-tillage wheat straw. Phytopathology 78: 1254.

Piedra Buena A. 2004. Agroecología de Meloidogyne Göldi, 1892 (Nematoda: Heteroderidae) en cultivos hortícolas protegidos. Tesis doctoral, Escuela Politécnica Superior, Universidad de Almería, España, 397 pp.

Piedra Buena A., García-álvarez A., Díez-Rojo M.A., Bello A. 2006. Use of crop residues for the control of Meloidogyne incognita under laboratory conditions. Pest Management Science 62: 919-926.

Piedra Buena A., García-Álvarez A., Díez-Rojo M.A., Ros C., Fernández P., Lacasa A., Bello A. 2007. Use of pepper crop residues for the cntrol of root-knot nematodes. Bioresource Technology 98: 2846-2851.

Pliego C., De Weert S., Lamers G.E.M., Bloemberg G., Cazorla F.M., Ramos C. 2006. Ocupación diferencial de la rizosfera de aguacate por cepas de Pseudomonas spp. Antagonistas frente a Rosellinia necatrix. Libro de resúmenes del XIII congreso de la SEF. Murcia, 18-22 septiembre 2006. p. 127.

Porras M., Barrau C., Romero F. 2006. Efecto de la combinación de Trichoderma y solaización sobre Colletotrichum spp. y Phytophthora cactorum en campos de fresa. Libro de resúmenes del XIII congreso de la SEF. Murcia, 18-22 septiembre 2006. p. 78.

Potera O. 1994. From bacteria: a new weapon against fungal infection. Science 265: 605 .

Poussier S., Trigalet-Demery D., Vanderwalle P., Goffinet B., Luisetti J., Trigalet A. 2000. Genetic diversity of $R$. solanacearum as assessed by PCR-RFLP of the hrp gene region AFLP and 16SrRNA sequence analysis, and identification of an African subdivision. Microbiology 146: 1679-1692. 
Pradhanang P.M., Momol M.T., Olson S.M., Jones J.B. 2003. Effects of plant essential oils on $R$. solanacearum population density and bacterial wilt incidence in tomato. Plant Disease 87: 423-426.

Pullman G.S., De Vay J.E., Garber R.H., Weinhold A.R. 1981a. Soil solarization: Effects on Vertillicium wilt of cotton and soilborne populations of Verticillium dahliae, Phytium spp., Rhizoctonia solani, and Thielaviopsis basicola. Phytopathology 71: 954-959.

Pullman G.S., De Vay J.E., Garber R.H. 1981b. Soil solarization and thermal death: a logarithmic relationship between time and temperature for four soilborne plant pathogens. Phutopathology 71: 959-964.

Punja Z.K., Grogan R.G. 1982. Effects of inorganic salts, carbonate-bicarbonate anions, ammonia, and the modifying influence of $\mathrm{pH}$ on sclerotial germination of Sclerotiumcrolfsii. Phytopathology 72: 635-639.

Rabeendran N., Jones E.E., Moot D.J., Stewart A. 2006. Biocontrol of Sclerotinia lettuce drop by Coniothyrium minitans and Trichoderma hamatum. Biological Control 39: 352-362.

Rahman M.A., Abdullah H., Vanhaecke M. 1999. Histopathology of susceptible and resistant Capsicum annuum cultivars infected with Ralstonia solanacearum. J. Phytopathology 147, 129-140.

Raio A., Zoina A., Moore W. 1997. The effect of solar heating of soil on natural and inoculated agrobacteria. Plant Pathology 46: 320-328.

Ramírez-Villapudua J., Munnecke D.E. 1987. Control of cabbage yellows (Fusarium oxysporum f. sp. conglutinans) by solar heating of field soils amended with dry cabbage residues. Plant Disease 71: 217-221.

Ramirez-Villapudua J., Munnecke D.E. 1988. Effect of solar heating and soil amendments of cruciferous residues on Fusarium oxysporum f. sp. conglutinans and other organisms. Phytopathology 78: 289-295.

Ramos C., Pomares F., Cebolla V., Gómez M., Roselló Olira J. 2004. Eficiencia de la solarización y contaminación por nitratos tras la aportación de estiércol. Comunicaciones del VI Congreso de la SEAE. Almería, 27 septiembre-2 octubre, 2004. pp. 411-418. 
Ramos-Solano B., Gutierrez-Mañero F.J., Hambreg M., Menéndez E., Borja M. 2006. Protección de geranio frente a Botrytis y Xanthomonas por distintas oxilipinas. Libro de resúmenes del XIII congreso de la SEF. Murcia, 18-22 septiembre 2006. p. 46.

Regalado R., Brito E., López-Cepero J., Bello A. 2006. Efectos de la biofumigación con residuos de cultivo sobre un suelo de cultivo de tomate. CD de Comunicacioens del VII Congreso de la SEAE. 18-23 Septiembre 2006, Zaragoza. $\mathrm{N}^{\mathrm{o}} 82$.

Reinoso Y. 2007. Aislamiento, selección e identificación de bacterias de los géeros Bacillus, Brevibacillus y Paenibacillus con potencialidades para el control biológico de bacterias y hongos fitopatógenos del cultivo de la papa (Solanum tuberosum L.). Fitosanidad 11: 59

Reinoso Y., Vaillant D., Casadesús L., García E., Pazos V. 2007a. Cepas de Brevibacillus laterosporus y Brevibacillus brevis antagonistas de bacterias y hongos fitopatógenos del cultivo de la papa (Solanum tuberosum L.). Fitosanidad 11: 79-80.

Reinoso Y., Vaillant D., Casadesús L., García E., Pazos V. 2007b. Selección de cepas de Bacillus y otros géneros relacionados para el control biológico de hongos fitopatógenos. Fitosanidad 11:35-40.

Ren L., Li G., Han Y.C., Jiang D.H., Huang H. 2007. Degradation of oxalic acid by Coniothyrium minitans ans its effects on production and activitty of $\beta-1,3-$ glucanase of this mycoparasite. Biological Control 43: 1-11.

Reyes J.M., De Cara M., Diánez F., Santos M., Segura J.M., Blanco R., Sánchez J.A., Tello J. 2004a. Efecto de la solarización, biofumigación y biosolarización sobre una fracción de la microbiota fúngica del suelo del olivar. Comunicaciones del VI congreso de la SEAE. Almería, 27 Septiembre-2 Octubre, 2004. pp. 583-597.

Reyes J.M., De Cara M., Diánez F., Santos M., Blanco R., Segura J.M., Sánchez J.A., Tello J.C. 2004b. Desinfección de suelos mediante biofumigación, solarización y biosolarización en el olivar. Bejarano-Alcázar J. 2004-a. Eficacia de la solarización del suelo para la erradicación de Verticillium dahliae en viveros de olivo. Libro de resúmenes del XII congreso de la SEF. Lloret de Mar, Girona, 26 septiembre-1 octubre 2004. p. 309. 
Rincón A.M., Moreno-Mateos M.A., Codón A.C., Benítez T. 2006. Mejora de la resistencia del tabaco a patógenos fúngicos y a estrés abiótico mediante la expresión de una $\beta$-1,3-glucanasa de Trichoderma harzianum. Libro de resúmenes del XIII congreso de la SEF. Murcia, 18-22 septiembre 2006. p. 52.

Rios J.J., Fernández-García E., Mínguez-Mosquera M.I., Pérez-Gálvez A. 2008. Description of volatile compounds geneated by the degradation of carotenoids in paprika, tomato and marigold oleoresins. Food Chemistry 106: 1145-1153.

Rodríguez-Kábana R. 1998. Alternatives to MB soil fumigation. En: A. Bello, J.A. González, M. Arias, R. Rodríguez-Kábana (Eds). Alternatives to Methyl Bromide for the Southern European Countries. DG XI EU, CSIC, Valencia, 1734.

Rodríguez-Kábana R. 2002. Sodium azide for soil pest control in crops with few or no alternatives to fumigation with methyl bromide. Proceedings of international conference on alternatives to methyl bromide. Sevilla, Spain 5-8 Marzo 2002. pp. 131-133.

Romero E., Zurera C., Barrau C., Romero F. 2006a. Efecto biofumigante de especies de Brassica en el crecimiento de Phytophthora spp. in vitro. Avance de resultados. Libro de resúmenes del XIII congreso de la SEF. Murcia, 18-22 septiembre 2006. p. 125.

Romero D., Zeriouh H., Cazorla F.M., Torés J.A., De Vicente A., PérezGarcía A. 2006b. Control biológico de oídio de cucurbitáceas mediante el uso de cepas de Bacillus subtilis. Libro de resúmenes del XIII congreso de la SEF. Murcia, 18-22 septiembre 2006. p. 108.

Ros C., Martínez M.A., Guerrero M.M., Torres J., Beltrán C., Lacasa A. 2006. Dosis de cloropicrina para la desinfección de suelos de pimiento. Libro de resúmenes del XIII congreso de la SEF. Murcia, 18-22 septiembre 2006. p. 374.

Rosa E.A., Heaney R.K., Fenwick G.R., Portas C.A.M. 1997. Glucosinolates in crop plants. Hortic. Rev. 19: 99-215.

Roszak D.B., Colwell R.R. 1987. Survival strategies of bacteria in the natural environmental. Microbiol. Rev. 51: 365-379.

Rusmin S., S.D. Ko. 1974. Rice-grown Rhizopus oligosporus inoculum for tempeh fermentation. Applied Microbiology 28: 347-350. 
Sabuquillo P., Cubrero J., Sztejnberg A., De Cal A., Melgarejo P. 2006. Modo de acción del agente de biocontrol Penicillium oxalicum frente a fusariosis del tomate. Libro de resúmenes del XIII congreso de la SEF. Murcia, 18-22 septiembre 2006. p. 48

Sacristán G., López-Robles D.J., Reguera-Useros J.I., González-Garcedo S. 2004. Biofumigación y control microbiológico contra el "Damping-Off" en remolacha azucarera causado por Rhizoctonia solana. Libro de resúmenes del XII congreso de la SEF. Lloret de Mar, Girona, 26 septiembre-1 octubre 2004. p. 313.

Sadfi N., Chérit M., Fliss I., Bondabbous A., Antoun H. 2001. Evaluation of bacterial isolates from salty soils and Bacillus thuringiensis strains for the biocontrol of Fusarium dry rot of potato tubers. Journal of Plant Pathology 83: 101118.

Saikia D., Khanuja S.P.S., Kahol A.P., Gupta S.C., Kumar S. 2001. Comparative antifungal activity of essential oils and constituents from three distinc genotypes of Cymbopogon spp. Current Science 80: 1264,1266.

Saile E., McGarvey J.A., Schell M.A., Denny T.P. 1997. Role of extracellular polysaccharide and endoglucanase in root invasion and colonization of tomato plants by Ralstonia solanacearum. Phytopathology 87: 1264-1271.

Sánchez-Vizcaíno J.M., Cambra M. 1981. Técnicas inmunoenzimáticas en patología animal y vegetal. Edit. Instituto Nacional de Investigaciones Agrarias. Madrid. 57pp.

Santander C., Montealegre J.R., Herrera R. 2003. Control biológico de Rhizoctonia solani en tomate en suelos previamente sometidos a solarización y bromuro de metilo. Cien. Inv. Agr. 30: 107-112.

Santos M., Boix A., Diánez F., Martínez R.E., Gámez I., De Cara M., Blanco R., Tello J. C. 2004. Papel biofumigante de los restos de cosecha de plantas hortícolas sobre Phytophthora capsici. Libro de resúmenes del XII congreso de la SEF. Lloret de Mar, Girona, 26 septiembre-1 octubre 2004. p. 314.

Schaad N.W. 1988. Laboratory guide for identification of plant pathogenic bacteria. $2^{a}$ edición. Edit. N.W. Schaad for the Bacteriology Committee of the American Phytopathological Society. St. Paul, Minnesota 1988, 158 pp.

Schell M. 2000. Control of virulence and pathogenicity genes of Ralstonia solanacearum by an elaborate sensory network. Annu. Rev. Phytopathol. 38: 263292. 
Schippers B., Bakker A.W., Bakker P.A.H.M. 1987. Interactions of deleterious and beneficial rhizosphere microorganism and the effect of cropping practices. Annual Review of Phytopathology 25: 339-358.

Schönfeld J., Gelsomino A., van Overbeek L.S., Gorissen A., Smalla K., van Elsas J.D. 2003. Effects of compost addition and simulated solarization on the fate of Ralstonia solanacearum biovar 2 and indigenous bacteria in soil. FEMS Microbiology Ecology 43: 63-74.

Schroth M.N., Hancock J.G. 1981. Selected topics in biological control. Annu. Rev. Microbiol. 35: 453-76.

Schroth M.N., Hancock J.G. 1982. Disease-suppressive soil and root-colonizing bacteria. Science 216:1376-81.

Segura J.M., De Cara M., Diánez F., Reyes J.M., García-Gámez I., Martínez R., Santos M., Boix A., Tello J. 2004. Evaluación de la biosolarización con restos de cosecha en un cultivo de tomate raf en un abrigo de malla en el Campillo de Gata (Najar, Almería). Comunicaciones del VI congreso de la SEAE. Almería, 27 Septiembre-2 Octubre, 2004. pp. 625-633.

Sherf A.F., MacNab A.A. 1986. Vegetable diseases and their control. Second Edition. New York W.A.: John Wiley and sons. New York, 728 pp.

Shlevin E., Sam Saguy I., Mahrer Y., Katan J. 2003. Modeling the survivla of two soilborne pathogens under dry structural solarization. Phytopathology 93: 1247-1257.

Shlevin E., Mahrer Y., Kritzman G., Katan J. 2004a. Survival of plant pathogens under structural solarization. Phytoparasitica 32: 470-478.

Shlevin E., Mahrer Y., Katan J. 2004b. Effect of moisture on thermal inactivation of soilborne pathogens under estructural solarization. Phytopathology 94: 132-137.

Shoemaker P.B., Echandi E. 1976. Seed and plant bed treatments for bacterial canker of tomato. Plant Disease Reporter 60: 163-166.

Shetty K.G., Subbarao K.V., Huisman O.C., Hubbard J.C. 2000. Mechanism of broccoli-mediated Verticillium wilt reduction in cauliflower. Phytopathology 90: 305-310. 
Silué D., Launay V., Tirilly Y. 1999. Pathogenic variability in Mycosphaerella brassicicola, the causal agent of the ringspot disease of crucifers. J. Phytopathology 147: 141-147.

Silva A., Romeiro R., Carrer R., Pereira J. 2004. Induction of systemic resistance by Bacillus cereus against tomato foliar diseases under field conditions. Journal of Phytopathology 152: 371-375.

Singh P.P., Shin Y.C., Park C.S., Chung Y.R. 1999. Biological control of fusarium wilt of cucumber by chitinolytic bacteria. Phytopathology 89: 92-99.

Smelt J.H. y Leistra M. 1974. Conversion of metham-sodium to methyl isothiocyanate and basic data on the behaviour of methyl isothiocyanate in soil. Pest. Sci. 5: 401-407.

Smiley R.W., Cook R.J., Papendick R.I. 1970. Anhydrous ammonia as a soil fungicide against Fusarium and fungicidal activity in the ammonia retention zone. Phytopathology 60: 1227-1232.

Smith B.J., Kirkrgaard J.A. 2002. In-vitro inhibition of soil microorganisms by 2-phenylethyl isothiocyanate. Plant. Pathol. 51: 585-593.

Singh R.S., Agnihotri S.S., Upadhyay S.N. 2006. Removal of toluene vapour using agro-waste as biofilter media. Bioresource Technology 97: 2296-2301.

Souto G., Correa O., Montecchia M., Kerber N., Pucheu N., Bachur M., García A. 2004. Genetic and functional characterization of a Bacillus sp. strain excreting surfacting and antifungal metabolites partially identified as iturin-like compounds. Journal of Applied Microbiology 97: 1247-1256.

Stapleton J.J., DeVay J.E. 1982a. Effect of soil solarization on populations of selected soilborne microorganism and growth of deciduous fruit tree seedlings. Phytopathology 72: 323-326.

Stapleton J.J., and DeVay J.E. 1982b. Changes in microbial populations in solarized soils as related to increased plant growth. (Abstr.) Phytopathology 72: 985.

Stapleton J.J., DeVay J.E. 1983. Response of phytoparasitic and free-living nematodes to soil solarization and 1,3-dichloropropene in California. Phytopathology 73: 1429-1436. 
Stapleton J.J., De Vay J.E., Quick J., Van Rijckevorsel H., De Boer G.J. 1983. Increased soluble mineral nutrients in soils as related to increased plant growth response following soil solarization. (Abstr.) Phytopathology 73: 814.

Stapleton J.J. and De Vay J.E. 1984. Thermal components of soil solarization as related to changes in soil and root microflora and increased plant growth response Phytopathology 74: 255-259.

Stapleton J.J. 2000. Soil solarization in various agricultural production systems. Crop protection 19: 837-841.

Stapleton J.J., Elmore C.L., De Vay J.E. 2000. Solarization and biofumigation help disinfest soil. California Agriculture 54: 42-45.

Stephens P.M., Davoren C.W., Wicks T. 1999. Effect of methyl bromide, metham sodium and the biofumigants Indian mustard and canola on the incidence of soilborne fungal pathogens and growth of grapevine nursery stock. Australasian Plant Pathol. 28: 187-196.

Stierle A.A., Upadhyay R., Hershenhorn J., Stroble G.A., Molina G. 1991. The phytotoxins of Mycosphaerella fijiensis, the causative agent of Black Sigatoka disease of bananas and plantains.. Experientia 47: 854-859.

Strider D.L. 1967. Survival studies with the tomato bacterial canker organisms. Phytopathology 57: 1067-1071.

Strider D.J. 1970. Tomato seedlings inoculations with Corynebacterium michiganense. Plant. Dis. Rep. 54: 36-39.

Sturz A.V., Peters R.D., Carter M.R., Sanderson J.B., Matheson B.G., Christie B.R. 2005. Variation in antibiosis ability, against potato pathogens, of bacterial communities recovered from the endo- and exoroots of potato crops produced under conventional versus minimum tillage systems. Cn. J. Microbiol. 51: 643654.

Sung S., Huang J. 1985. Formulated soil amendment for controlling Fusarium wilt and other soilborne diseases. Plant Disease 69: 917-920.

Suslow T.V., Schroth M.N. 1982. Role of deleterious rhizobacteria as minor pathogens in reducing crop growth. Phytopathology 72: 111-115.

Tans-Kersten J., Huang H., Allen C. 2001. Ralstonia solanacearum needs motility for invasive virulence on tomato. J. Bacteriol. 183: 3597-3605. 
Tello J.C. 1977. Algunas consideraciones sobre la desinfección de suelos hortícolas. Levante Agrícola, 191. pp. 11-19.

Tello J.C. 1988. La competición microbiana en el suelo. Horticultura 39, 65-83.

Tello J. 1998. Crop management as an alternative to methyl bromide in Spain. En: A. Bello, J.A. González, M. Arias, R. Rodríguez-Kábana (Eds). Alternatives to Methyl Bromide for the Southern European Countries. DG XI EU, CSIC, Valencia, 53-72.

Tello J.C. 2002. Tomato production in Spain without methyl bromide. Proceedings of international conference on alternatives to methyl bromide. Sevilla, Spain 5-8 Marzo 2002. pp. 169-175.

Tello J.C., Rodríguez Molina, M.C. 1998. El patosistema vegetal: una reflexión necesaria. In: Phytoma-España (Ed.). La sanidad del cultivo del tomate. pp. 19-42.

Tello J.C., Bello A. 2002. Plastics in the disinfection of agriculture land. Plasticulture 121: 50-71.

Thera A.T. 2007. Bacterial wilt management: a prerequisite for a potato seed certification program in Mali. Tesis de Máster. Departamento Patología Vegetal. 128 pp. http://etd.lib.montana.edu/etd/2007/thera/TheraA1207.pdf 20-8-08

Thompson L.M. 1962. El suelo y su fertilidad. Ed. Reverté S.A. Zaragoza. 407pp.

Thyr B.D., Samuel M.J., Brown P.G. 1975. New solanaceous host records for Corynebacterium michiganense. Plant Disease Reporter 59: 595-598.

Timms-Wilson T.M., Tracey M., Bryant K., Bailey M.J. 2001. Strain characterization and 16S-23S-probe development for differentiating geographically dispersed isolates of the phytopathogen $R$. solanacearum. Environ. Microbiol. 3: 785-797.

Tjamos E.C., Antoniou P., Panagopoulos C.G. 1992. Control of bacterial canker of tomato by application of soil solarization. (Abstr.) Phytopathology 82: 1076.

Trevors J.T., Finnen R.L. 1990. Introduction and recovery of Clavibacter michiganensis subsp. michiganensis from agricultural soil. Plant and Soil 126: 141143. 
Trillas M.I., Casanova E., Sant M.D., Segarra G., Borrero C., Avilés M. 2006. Trichoderma asperellum (T34): reducción de las enfermedades producidas por Fusarium oxysporum y Rhizoctonia solani. Libro de resúmenes del XIII congreso de la SEF. Murcia, 18-22 septiembre 2006. p. 47.

Tripathi R.D., Banerji R., Sharma M.L., Balasubrahmanyam V.R., Nigam S.K. 1985. Toxicity of essential oil from a new strain of Ocimum gratissimum (Clocimum) against betelvine pathogenic fungi. Agric. Biol. Chem., 49: 22772282.

Tsao P.H., Oster J.J. 1981. Relation of ammonia and nitrous acid to suppression of Phytophthora in soils amended with nitrogenous organic substances. Phytopathology 71: 53-59.

Tsiantos J. 1987. Transmission of bacterium Corynebacterium michiganense pv. michiganense by seeds. J. Phytopathology 119: 142-146.

Turner N.J., Corden M.E. 1963. Decomposition of N-methyldithiocarbamate in soil. Phytopathology 53:1388-1394.

UC Davis. 2007. UC pest management guidelines http://www.ipm.ucdavis.edu 24-9-07

Uclés Aguilera, D., Hernández Torrecillas R. 2003. Macromagnitudes de la agricultura intensiva. En: Fernández Rodríguez E.J. (coord.) Innovaciones tecnológicas en cultivos de invernadero. Ed. Aerotécnicas, Madrid, pp.1-9.

Usall J., Cañamás T., Casals C., Solsona C., Viñas I., Teixidó N. 2006. Mejora de Pantoea agglomerans CPA-2 para su aplicación en campo en el control de las principales podredumbres de postcosecha de cítricos. Libro de resúmenes del XIII congreso de la SEF. Murcia, 18-22 septiembre 2006. p. 49.

Van den Ende J.E. 1993a. Seedbed infection of white cabbage by Mycosphaerella brassicicola. Neth. J. P1. Path. 99: 139-148.

Van den Ende J.E. 1993b. Differential interaction of Mycosphaerella brassicicola and Brassica cultivars. Neth. J. Pl. Path. 99: 149-162.

Van den Ende J.E. 1998. Ring spot disease of brassica crops: resistance and epidemiology. PhD Thesis, Wageningen Agricultural University, The Netherlands, $123 \mathrm{pp}$. 
Van der Bulk R.W., Zevenhuizen L.P.T.M., Cordewener J.H.C., Dons J.J.M. 1991. Characterization of the extracellular polysaccharide produced by Clavibacter michiganensis subsp. michiganensis. Phytopathology 81: 619-623.

Van der Meulen E.S., Nol L., Cammeraat L.H. 2006. Effects of irrigation and plastic mulch on soil properties on semiarid abandoned fields. Soil Science Society of America Journal 70: 930-939.

Van der Wolf J.M., Vriend S.G.C., Kastelein P., Nijhuis E.H., van Bekkum P.J., van Vuurde J.W.L. 2000. Immunofluorescence colony-staining (IFC) for detection and quantification of Ralstonia (Pseudomonas) solanacearum biovar 2 (race 3) in soil and verification of positive results by PCR and dilution plating. European Journal of Plant Pathology 106: 123-133.

Van Elsas J.D., Kastelein P., Van Bekkum P., Van der Wolf P.M., De Vries P.M., Van Overbeek L.S. 2000. Survival of Ralstonia solanacearum biovar 2, the causative agent of brown rot, in field and microcosm soil temperature climates. Phytopathology 90: 1358-1366.

Van Elsas J.D., Kastelein P., De Vries P.M., Van Overbreek L.S. 2001. Effects of ecological factors on the survival physiology of Ralstonia solanacearum bv. 2 in irrigation water. Can. J. Microbiol. 47: 1-13.

Verkley G.J.M., da Silva M., Wicklow D.T., Crous P.W. 2004. Paraconiothyrium, a new genus to accommodate the mycoparasite Coniothyrium minitans, anamorphs of Paraphaeosphaeria, and four new spwcies. Studies in Mycology 50: 323-325.

Vidaver A.K., Lambrecht P.A. 2004. Las bacterias como patógenos vegetales. The plant Health Instructor. DOI: 10.10904/PHI-I-2006-0601-01. www.apsnet.org 31-1-07

Vilaseca J.C. 2007. Papel biofumigante de los restos de cosecha en el control de ToMV, PepMV y O. brassicae. Tesis doctoral. Departamento de Ecosistemas Agroforestales. Universidad Politécnica de Valencia.478pp.

Wallis F.M. 1977. Ultrastructural histopathology of tomato plants infected with Corynebacterium michiganense. Physiol. Plant. Pathology 11: 333-342.

Warton B., Matthiessen J.N. 2005. The crucial ole of calcium interacting with soil $\mathrm{pH}$ in enhanced biodegradation of metham-sodium. Pest Manag. Sci. 67:856862. 
Whipps J.M. 2000. Microbial interactions and biocontrol in the rhizosphere. Journal of Experimental Botany 52: 487-511.

Weller D.M. 1988. Biological control of soilborne plant pathogens in the rhizosphere with bacteria. Ann. Rev. Phytopathol. 26: 379-407.

Weller D.M., Cook R.J. 1983. Supression of take-all of wheat by seed treatments with fluorescent pseudomonads. Phytopathology 73: 463-469.

West A., Burges H.D., Dixon T., Wyborn C.H. 1985. Survival of Bacillus thuringiensis and Bacillus cereus spore inocula in soil: effects of $\mathrm{pH}$ moisture, nutrient availability and indigenous microorganisms. Soil Biol. Biochem. 17:657665.

Whipps J.M., Gerlagh M. 1992. Biology of Coniothyrium minitans and its potential for use in desease biocontrol. Mycol. Res. 96: 897.

Wicks T., Lommam G., Rogers I.S. 1987. Fungicide control of ringspot (Mycosphaerella brassicicola) in Brussels sprouts. Australian Journal of Experimental Agriculture (Australia) 27: 597-600.

Wilhelm S. 1951. Effect of various soil amendments on the inoculum potential of Verticillium wilt fungus. Phytopathology 41: 684-690.

Yélamos J.A., Castillo P., Diánez F., Villaescusa J., Santos M., Chebâani M., Blanco R., Lacasa A., Tello J.C. 2002. Efectos del bromuro de metilo y la biofumigación con solarización sobre la microbiota fúngica, actinomicética y bacteriana de suelos cultivados con pimiento en Murcia. Comunicaciones del V congreso de la SEAE. Gijón, 16-21 Septiembre, 2002. pp. 1023-1025.

Yu J.Q. 1999. Allelopathic supression of Pseudomonas solanacearum infection of tomato (Lycopersicon sculentum) in tomato-chinese chive (Allium tuberosum) intercropping system. Journal of Chemical Ecology 25, 2409-2417.

Yücel S. 1995. A study on soil solarization and combined with fumigant application to control Phytophtora crown blight (Phytophtora capsici Leonian) on peppers in the East Mediterranean region of Turkey. Crop protection 14: 653-655.

Zakaria M.A., Lockwood J.L. 1980. Reduction in Fusarium populations in soil by oilseed meal amendments. Phytopathology 70: 240-243.

Zentmyer G.A. 1963. Biological control of Phytophthora root rot of avocado with alfalfa meal. Phytopathology 53: 1383-1387. 
Zeriouh H., Romero D., Cazorla F.M., De Vicente A., Pérez-García A. 2006. Papel de los antibióticos de Bacillus subtilis en el control biológico de enfermedades bacterianas de cucurbitáceas. Libro de resúmenes del XIII congreso de la SEF. Murcia, 18-22 septiembre 2006. p. 334. 


\section{ANEJO 1}

Identificación de muestras del trabajo en campo

\begin{tabular}{|c|c|c|c|c|c|}
\hline \multicolumn{2}{|c|}{$\begin{array}{l}\text { Número } \\
\text { muestra }\end{array}$} & \multirow{2}{*}{$\begin{array}{l}\text { BLOQUE } \\
\text { Block } 1\end{array}$} & \multirow{2}{*}{$\begin{array}{c}\text { LOCALIDAD } \\
\text { A }\end{array}$} & \multirow{2}{*}{$\begin{array}{c}\text { TRATAMIENTO } \\
-\end{array}$} & \multirow{2}{*}{$\begin{array}{c}\text { MUESTREC } \\
\text { T0 }\end{array}$} \\
\hline sp07B & 217 & & & & \\
\hline sp07B & 218 & Block 1 & $A$ & - & T0 \\
\hline sp07B & 219 & Block 2 & $A$ & - & T0 \\
\hline sp07B & 220 & Block 2 & $A$ & - & T0 \\
\hline sp07B & 221 & Block 3 & $A$ & _- & TO \\
\hline sp07B & 222 & Block 3 & $A$ & - & T0 \\
\hline sp07B & 223 & Block 1 & B & - & T0 \\
\hline sp07B & 224 & Block 1 & B & - & T0 \\
\hline sp07B & 225 & Block 2 & B & - & T0 \\
\hline sp07B & 226 & Block 2 & B & - & T0 \\
\hline sp07B & 227 & Block 3 & B & - & T0 \\
\hline sp07B & 228 & Block 3 & B & - & T0 \\
\hline sp07B & 1 & Block 1 & $A$ & Prophyta & $\mathrm{T} 1$ \\
\hline sp07B & 5 & Block 1 & A & B255 & $\mathrm{T} 1$ \\
\hline sp07B & 9 & Block 1 & $A$ & Urea & $\mathrm{T} 1$ \\
\hline sp07B & 13 & Block 1 & $A$ & Erwinia & $\mathrm{T} 1$ \\
\hline sp07B & 17 & Block 1 & $A$ & Conioth & $\mathrm{T} 1$ \\
\hline sp07B & 21 & Block 1 & $A$ & Control & $\mathrm{T} 1$ \\
\hline sp07B & 25 & Block 1 & A & Pack top & $\mathrm{T} 1$ \\
\hline sp07B & 26 & Block 1 & $A$ & Pack center & $\mathrm{T} 1$ \\
\hline sp07B & 27 & Block 1 & $A$ & Pack bottom & $\mathrm{T} 1$ \\
\hline sp07B & 37 & Block 1 & B & Prophyta & $\mathrm{T} 1$ \\
\hline sp07B & 41 & Block 1 & B & B255 & $\mathrm{T} 1$ \\
\hline sp07B & 45 & Block 1 & B & Urea & $\mathrm{T} 1$ \\
\hline sp07B & 49 & Block 1 & ${ }^{B} 257$ & Erwinia & $\mathrm{T} 1$ \\
\hline
\end{tabular}




\begin{tabular}{|c|c|c|c|c|}
\hline sp07B & 53 & Block 1 & B & Conioth \\
\hline sp07B & 57 & Block 1 & B & Control \\
\hline sp07B & 61 & Block 1 & B & Pack top \\
\hline sp07B & 62 & Block 1 & B & Pack center \\
\hline sp07B & 63 & Block 1 & $\mathrm{~B}$ & Pack bottom \\
\hline sp07B & 73 & Block 2 & A & Prophyta \\
\hline sp07B & 77 & Block 2 & A & B255 \\
\hline sp07B & 81 & Block 2 & A & Urea \\
\hline sp07B & 85 & Block 2 & A & Erwinia \\
\hline sp07B & 89 & Block 2 & A & Conioth \\
\hline sp07B & 93 & Block 2 & A & Control \\
\hline sp07B & 97 & Block 2 & A & Pack top \\
\hline sp07B & 98 & Block 2 & A & Pack center \\
\hline sp07B & 99 & Block 2 & A & Pack bottom \\
\hline sp07B & 109 & Block 2 & B & Prophyta \\
\hline sp07B & 113 & Block 2 & B & B255 \\
\hline sp07B & 117 & Block 2 & B & Urea \\
\hline sp07B & 121 & Block 2 & B & Erwinia \\
\hline sp07B & 125 & Block 2 & B & Conioth \\
\hline sp07B & 129 & Block 2 & B & Control \\
\hline sp07B & 133 & Block 2 & B & Pack top \\
\hline sp07B & 134 & Block 2 & B & Pack center \\
\hline sp07B & 135 & Block 2 & B & Pack bottom \\
\hline sp07B & 145 & Block 3 & $A$ & Prophyta \\
\hline sp07B & 149 & Block 3 & A & B255 \\
\hline sp07B & 153 & Block 3 & $A$ & Urea \\
\hline sp07B & 157 & Block 3 & $A$ & Erwinia \\
\hline sp07B & 161 & Block 3 & $A$ & Conioth \\
\hline sp07B & 165 & Block 3 & $A$ & Control \\
\hline sp07B & 169 & Block 3 & $A$ & Pack top \\
\hline sp07B & 170 & Block 3 & ${ }^{A} 258$ & Pack center \\
\hline
\end{tabular}




\begin{tabular}{|c|c|c|c|c|}
\hline sp07B & 171 & Block 3 & A & Pack bottom \\
\hline sp07B & 181 & Block 3 & B & Prophyta \\
\hline sp07B & 185 & Block 3 & B & B255 \\
\hline sp07B & 189 & Block 3 & B & Urea \\
\hline sp07B & 193 & Block 3 & B & Erwinia \\
\hline sp07B & 197 & Block 3 & B & Conioth \\
\hline sp07B & 201 & Block 3 & B & Control \\
\hline sp07B & 205 & Block 3 & B & Pack top \\
\hline sp07B & 206 & Block 3 & B & Pack center \\
\hline sp07B & 207 & Block 3 & B & Pack bottom \\
\hline sp07B & 2 & Block 1 & $A$ & Prophyta \\
\hline sp07B & 6 & Block 1 & $A$ & B255 \\
\hline sp07B & 10 & Block 1 & $A$ & Urea \\
\hline sp07B & 14 & Block 1 & $A$ & Erwinia \\
\hline sp07B & 18 & Block 1 & $A$ & Conioth \\
\hline sp07B & 22 & Block 1 & $A$ & Control \\
\hline sp07B & 28 & Block 1 & $A$ & Pack top \\
\hline sp07B & 29 & Block 1 & $A$ & Pack center \\
\hline sp07B & 30 & Block 1 & $A$ & Pack bottom \\
\hline sp07B & 38 & Block 1 & B & Prophyta \\
\hline sp07B & 42 & Block 1 & B & B255 \\
\hline sp07B & 46 & Block 1 & B & Urea \\
\hline sp07B & 50 & Block 1 & B & Erwinia \\
\hline sp07B & 54 & Block 1 & B & Conioth \\
\hline sp07B & 58 & Block 1 & B & Control \\
\hline sp07B & 64 & Block 1 & B & Pack top \\
\hline sp07B & 65 & Block 1 & B & Pack center \\
\hline sp07B & 66 & Block 1 & B & Pack bottom \\
\hline sp07B & 74 & Block 2 & $A$ & Prophyta \\
\hline sp07B & 78 & Block 2 & A & B255 \\
\hline sp07B & 82 & Block 2 & A & Urea \\
\hline
\end{tabular}




\begin{tabular}{|c|c|c|c|c|c|}
\hline sp07B & 86 & Block 2 & A & Erwinia & $\mathrm{T} 2$ \\
\hline sp07B & 90 & Block 2 & A & Conioth & $\mathrm{T} 2$ \\
\hline sp07B & 94 & Block 2 & A & Control & T2 \\
\hline sp07B & 100 & Block 2 & A & Pack top & $\mathrm{T} 2$ \\
\hline sp07B & 101 & Block 2 & A & Pack center & $\mathrm{T} 2$ \\
\hline sp07B & 102 & Block 2 & A & Pack bottom & $\mathrm{T} 2$ \\
\hline sp07B & 110 & Block 2 & $B$ & Prophyta & $\mathrm{T} 2$ \\
\hline sp07B & 114 & Block 2 & $B$ & B255 & T2 \\
\hline sp07B & 118 & Block 2 & $B$ & Urea & $\mathrm{T} 2$ \\
\hline sp07B & 122 & Block 2 & B & Erwinia & $\mathrm{T} 2$ \\
\hline sp07B & 126 & Block 2 & $B$ & Conioth & T2 \\
\hline sp07B & 130 & Block 2 & $B$ & Control & T2 \\
\hline sp07B & 136 & Block 2 & B & Pack top & $\mathrm{T} 2$ \\
\hline sp07B & 137 & Block 2 & B & Pack center & $\mathrm{T} 2$ \\
\hline sp07B & 138 & Block 2 & $B$ & Pack bottom & T2 \\
\hline sp07B & 146 & Block 3 & A & Prophyta & $\mathrm{T} 2$ \\
\hline sp07B & 150 & Block 3 & A & B255 & $\mathrm{T} 2$ \\
\hline sp07B & 154 & Block 3 & A & Urea & $\mathrm{T} 2$ \\
\hline sp07B & 158 & Block 3 & A & Erwinia & T2 \\
\hline sp07B & 162 & Block 3 & A & Conioth & $\mathrm{T} 2$ \\
\hline sp07B & 166 & Block 3 & A & Control & $\mathrm{T} 2$ \\
\hline sp07B & 172 & Block 3 & A & Pack & $\mathrm{T} 2$ \\
\hline sp07B & 182 & Block 3 & B & Prophyta & $\mathrm{T} 2$ \\
\hline sp07B & 186 & Block 3 & B & B255 & $\mathrm{T} 2$ \\
\hline sp07B & 190 & Block 3 & B & Urea & $\mathrm{T} 2$ \\
\hline sp07B & 194 & Block 3 & $B$ & Erwinia & $\mathrm{T} 2$ \\
\hline sp07B & 198 & Block 3 & $B$ & Conioth & $\mathrm{T} 2$ \\
\hline sp07B & 202 & Block 3 & $B$ & Control & T2 \\
\hline sp07B & 208 & Block 3 & B & Pack & T2 \\
\hline
\end{tabular}


sp07B

3 Block 1

A

Prophyta

sp07B

7 Block 1

A

B255

T3

sp07B 11 Block 1

A

Urea

T3

sp07B $\quad 15$ Block 1

A

Erwinia

T3

sp07B

A

Conioth

T3

sp07B 23 Block 1

A Control

T3

sp07B

31 Block 1

A

Pack

T3

sp07B

39 Block 1

B

Prophyta

T3

sp07B

43 Block 1

B255

T3

sp07B

47 Block 1

B

Urea

T3

sp07B

51 Block 1

B

Erwinia

T3

sp07B

55 Block 1

B

Conioth

T3

sp07B

59 Block 1

B

Control

T3

sp07B

67 Block 1

B

Pack

T3

$\begin{array}{lrlccc}\text { sp07B } & 75 & \text { Block 2 } & \text { A } & \text { Prophyta } & \text { T3 } \\ \text { sp07B } & 79 & \text { Block 2 } & \text { A } & \text { B255 } & \text { T3 } \\ \text { sp07B } & 83 & \text { Block 2 } & \text { A } & \text { Urea } & \text { T3 } \\ \text { sp07B } & 87 & \text { Block 2 } & \text { A } & \text { Erwinia } & \text { T3 } \\ \text { sp07B } & 91 & \text { Block 2 } & \text { A } & \text { Conioth } & \text { T3 } \\ \text { sp07B } & 95 & \text { Block 2 } & \text { A } & \text { Control } & \text { T3 } \\ \text { sp07B } & 103 & \text { Block 2 } & \text { A } & \text { Pack } & \text { T3 }\end{array}$

sp07B 111 Block 2
B Prophyta
B255




$\begin{array}{llllcl}\text { sp07B } & \text { 119 } & \text { Block 2 } & \text { B } & \text { Urea } & \text { T3 } \\ \text { sp07B } & 123 & \text { Block 2 } & \text { B } & \text { Erwinia } & \text { T3 } \\ \text { sp07B } & 127 & \text { Block 2 } & \text { B } & \text { Conioth } & \text { T3 } \\ \text { sp07B } & 131 & \text { Block 2 } & \text { B } & \text { Control } & \text { T3 } \\ \text { sp07B } & 139 & \text { Block 2 } & \text { B } & \text { Pack } & \text { T3 }\end{array}$

$\begin{array}{llllcl}\text { sp07B } & 147 & \text { Block 3 } & \text { A } & \text { Prophyta } & \text { T3 } \\ \text { sp07B } & 151 & \text { Block 3 } & \text { A } & \text { B255 } & \text { T3 } \\ \text { sp07B } & 155 & \text { Block 3 } & \text { A } & \text { Urea } & \text { T3 } \\ \text { sp07B } & 159 & \text { Block 3 } & \text { A } & \text { Erwinia } & \text { T3 } \\ \text { sp07B } & 163 & \text { Block 3 } & \text { A } & \text { Conioth } & \text { T3 } \\ \text { sp07B } & 167 & \text { Block 3 } & \text { A } & \text { Control } & \text { T3 } \\ \text { sp07B } & 175 & \text { Block 3 } & \text { A } & \text { Pack } & \text { T3 }\end{array}$

$\begin{array}{llllcl}\text { sp07B } & 183 & \text { Block 3 } & \text { B } & \text { Prophyta } & \text { T3 } \\ \text { sp07B } & 187 & \text { Block 3 } & \text { B } & \text { B255 } & \text { T3 } \\ \text { sp07B } & 191 & \text { Block 3 } & \text { B } & \text { Urea } & \text { T3 } \\ \text { sp07B } & 195 & \text { Block 3 } & \text { B } & \text { Erwinia } & \text { T3 } \\ \text { sp07B } & 199 & \text { Block 3 } & \text { B } & \text { Conioth } & \text { T3 } \\ \text { sp07B } & 203 & \text { Block 3 } & \text { B } & \text { Control } & \text { T3 } \\ \text { sp07B } & 211 & \text { Block 3 } & \text { B } & \text { Pack } & \text { T3 }\end{array}$

$\begin{array}{lrllcl}\text { sp07B } & 4 & \text { Block 1 } & \text { A } & \text { Prophyta } & \text { T4 } \\ \text { sp07B } & 8 & \text { Block 1 } & \text { A } & \text { B255 } & \text { T4 } \\ \text { sp07B } & 12 & \text { Block 1 } & \text { A } & \text { Urea } & \text { T4 } \\ \text { sp07B } & 16 & \text { Block 1 } & \text { A } & \text { Erwinia } & \text { T4 } \\ \text { sp07B } & 20 & \text { Block 1 } & \text { A } & \text { Conioth } & \text { T4 } \\ \text { sp07B } & 24 & \text { Block 1 } & \text { A } & \text { Control } & \text { T4 }\end{array}$




$\begin{array}{lclccc}\text { sp07B } & \text { 34 } & \text { Block 1 } & \text { A } & \text { Pack } & \text { T4 } \\ & & & & & \\ \text { sp07B } & 40 & \text { Block 1 } & \text { B } & \text { Prophyta } & \text { T4 } \\ \text { sp07B } & 44 & \text { Block 1 } & \text { B } & \text { B255 } & \text { T4 } \\ \text { sp07B } & 48 & \text { Block 1 } & \text { B } & \text { Urea } & \text { T4 } \\ \text { sp07B } & 52 & \text { Block 1 } & \text { B } & \text { Erwinia } & \text { T4 } \\ \text { sp07B } & 56 & \text { Block 1 } & \text { B } & \text { Conioth } & \text { T4 } \\ \text { sp07B } & 60 & \text { Block 1 } & \text { B } & \text { Control } & \text { T4 } \\ \text { sp07B } & 70 & \text { Block 1 } & \text { B } & \text { Pack } & \text { T4 }\end{array}$

$\begin{array}{lrlccc}\text { sp07B } & 76 & \text { Block 2 } & \text { A } & \text { Prophyta } & \text { T4 } \\ \text { sp07B } & 80 & \text { Block 2 } & \text { A } & \text { B255 } & \text { T4 } \\ \text { sp07B } & 84 & \text { Block 2 } & \text { A } & \text { Urea } & \text { T4 } \\ \text { sp07B } & 88 & \text { Block 2 } & \text { A } & \text { Erwinia } & \text { T4 } \\ \text { sp07B } & 92 & \text { Block 2 } & \text { A } & \text { Conioth } & \text { T4 } \\ \text { sp07B } & 96 & \text { Block 2 } & \text { A } & \text { Control } & \text { T4 } \\ \text { sp07B } & 106 & \text { Block 2 } & \text { A } & \text { Pack } & \text { T4 }\end{array}$

$\begin{array}{llllcl}\text { sp07B } & 112 & \text { Block 2 } & \text { B } & \text { Prophyta } & \text { T4 } \\ \text { sp07B } & 116 & \text { Block 2 } & \text { B } & \text { B255 } & \text { T4 } \\ \text { sp07B } & 120 & \text { Block 2 } & \text { B } & \text { Urea } & \text { T4 } \\ \text { sp07B } & 124 & \text { Block 2 } & \text { B } & \text { Erwinia } & \text { T4 } \\ \text { sp07B } & 128 & \text { Block 2 } & \text { B } & \text { Conioth } & \text { T4 } \\ \text { sp07B } & 132 & \text { Block 2 } & \text { B } & \text { Control } & \text { T4 } \\ \text { sp07B } & 142 & \text { Block 2 } & \text { B } & \text { Pack } & \text { T4 }\end{array}$

sp07B 148 Block 3

A Prophyta

T4 


$\begin{array}{llllcl}\text { sp07B } & 152 & \text { Block 3 } & \text { A } & \text { B255 } & \text { T4 } \\ \text { sp07B } & 156 & \text { Block 3 } & \text { A } & \text { Urea } & \text { T4 } \\ \text { sp07B } & 160 & \text { Block 3 } & \text { A } & \text { Erwinia } & \text { T4 } \\ \text { sp07B } & 164 & \text { Block 3 } & \text { A } & \text { Conioth } & \text { T4 } \\ \text { sp07B } & 168 & \text { Block 3 } & \text { A } & \text { Control } & \text { T4 } \\ \text { sp07B } & 178 & \text { Block 3 } & \text { A } & \text { Pack } & \text { T4 } \\ & & & & & \\ & & & & & \\ \text { sp07B } & 184 & \text { Block 3 } & \text { B } & \text { Prophyta } & \text { T4 } \\ \text { sp07B } & 188 & \text { Block 3 } & \text { B } & \text { B255 } & \text { T4 } \\ \text { sp07B } & 192 & \text { Block 3 } & \text { B } & \text { Urea } & \text { T4 } \\ \text { sp07B } & 196 & \text { Block 3 } & \text { B } & \text { Erwinia } & \text { T4 } \\ \text { sp07B } & 200 & \text { Block 3 } & \text { B } & \text { Conioth } & \text { T4 } \\ \text { sp07B } & 204 & \text { Block 3 } & \text { B } & \text { Control } & \text { T4 } \\ \text { sp07B } & 214 & \text { Block 3 } & \text { B } & \text { Pack top } & \text { T4 } \\ \text { sp07B } & 215 & \text { Block 3 } & \text { B } & \text { Pack center } & \text { T4 } \\ \text { sp07B } & 216 & \text { Block 3 } & \text { B } & \text { Pack bottom } & \text { T4 }\end{array}$




\section{ANEJO 2}

Volumen de suspensión aplicada por pulverización y tratamiento

Pulverización 1 (5 Octubre 2007)

\begin{tabular}{cccc} 
Tratamiento & $\begin{array}{c}\text { Volumen inicial } \\
(\mathbf{m l})\end{array}$ & $\begin{array}{c}\text { Suspensión } \\
\text { restante } \\
(\mathbf{m l})\end{array}$ & $\begin{array}{c}\text { Suspensión aplicada } \\
(\mathbf{m l})\end{array}$ \\
\hline Control & 3000 & 750 & 2250 \\
\hline Pack & 3000 & 1700 & 1300 \\
\hline Urea & 3000 & 950 & 2050 \\
\hline B255 & 3000 & 800 & 2200 \\
\hline Erwinia & 3000 & 750 & 2250 \\
\hline Antagonista & 3000 & 560 & 2350 \\
\hline $\begin{array}{c}\text { Coniothyriu } \\
\text { m }\end{array}$ & 3000 & 850 & 2150 \\
\hline
\end{tabular}

Pulverización 2 (19 Octubre 2007)

\begin{tabular}{cccc} 
Tratamiento & $\begin{array}{c}\text { Volumen inicial } \\
(\mathbf{m l})\end{array}$ & $\begin{array}{c}\text { Suspensión } \\
\text { restante } \\
(\mathbf{m l})\end{array}$ & $\begin{array}{c}\text { Suspensión aplicada } \\
(\mathbf{m l})\end{array}$ \\
\hline Control & 2500 & 160 & 2340 \\
\hline Pack & 2500 & 1000 & 1500 \\
\hline Urea & 2500 & 350 & 2150 \\
\hline B255 & 2500 & 160 & 2340 \\
\hline Erwinia & 2500 & 165 & 2335 \\
\hline Antagonista & 2500 & 220 & 2280 \\
\hline $\begin{array}{c}\text { Coniothyriu } \\
\text { m }\end{array}$ & 2500 & 160 & 2340 \\
\hline
\end{tabular}



ANEJO 3

A. Estudio de lesiones en hojas del primer muestreo (T0)

\begin{tabular}{|c|c|c|c|c|c|}
\hline Taqman & peso antes (g) & $\begin{array}{c}\text { peso después } \\
(\mathrm{g})\end{array}$ & lesión & medida $(\mathrm{cm})$ & lesiones totales \\
\hline \multirow[t]{8}{*}{217} & 175,34 & 172,65 & 1 & $0,3-0,3$ & 16 \\
\hline & & & 2 & $0,5-0,6$ & 41 \\
\hline & & & 3 & $0,6-0,7$ & 11 \\
\hline & & & 4 & $0,3-0,5$ & 15 \\
\hline & & & 5 & $0,3-0,5$ & 9 \\
\hline & & & 6 & $0,5-0,6$ & 28 \\
\hline & & & 7 & $0,7-0,8$ & 23 \\
\hline & & & 8 & $0,3-0,3$ & 10 \\
\hline \multirow[t]{8}{*}{218} & 197,37 & 195,19 & 1 & $0,5-0,5$ & 5 \\
\hline & & & 2 & $1-0,8$ & 8 \\
\hline & & & 3 & $0,6-0,8$ & 9 \\
\hline & & & 4 & $0,3-0,3$ & 10 \\
\hline & & & 5 & $0,5-0,5$ & 19 \\
\hline & & & 6 & $0,3-0,3$ & 10 \\
\hline & & & 7 & $0,6-0,6$ & 11 \\
\hline & & & 8 & $0,3-0,4$ & 15 \\
\hline \multirow[t]{8}{*}{219} & 201,04 & 199,05 & 1 & $0,3-0,3$ & 26 \\
\hline & & & 2 & $0,5-0,8$ & 7 \\
\hline & & & 3 & $0,3-0,4$ & 15 \\
\hline & & & 4 & $0,6-0,8$ & 18 \\
\hline & & & 5 & $0,5-0,3$ & 14 \\
\hline & & & 6 & $0,3-0,3$ & 10 \\
\hline & & & 7 & $0,5-0,5$ & 8 \\
\hline & & & 8 & $0,3-0,3$ & 24 \\
\hline \multirow[t]{8}{*}{220} & 201,59 & 199,16 & 1 & $0,5-0,5$ & 2 \\
\hline & & & 2 & $0,3-0,4$ & 13 \\
\hline & & & 3 & $0,9-1$ & 47 \\
\hline & & & 4 & $0,5-0.4$ & 4 \\
\hline & & & 5 & $0,2-0,3$ & 32 \\
\hline & & & 6 & $0,5-0,5$ & 21 \\
\hline & & & 7 & $0,3-0,3$ & 6 \\
\hline & & & 8 & $0,5-0,5$ & 84 \\
\hline \multirow[t]{3}{*}{221} & 198,95 & 196,47 & 1 & $0,6-0,8$ & 14 \\
\hline & & & 2 & $0,8-, 8$ & 31 \\
\hline & & & 3 & $0,3-0,5$ & 53 \\
\hline
\end{tabular}




\begin{tabular}{|c|c|c|c|c|c|}
\hline & & & 4 & $0,5-0,5$ & 53 \\
\hline & & & 5 & $0,6-0,6$ & 66 \\
\hline & & & 6 & $1-0,8$ & 72 \\
\hline & & & 7 & $0,4-0,5$ & 4 \\
\hline & & & 8 & $0,5-0,5$ & 4 \\
\hline \multirow[t]{8}{*}{222} & 229,54 & 226,53 & 1 & $0,3-0,3$ & 24 \\
\hline & & & 2 & $0,3-0,2$ & 7 \\
\hline & & & 3 & $0,2-0,4$ & 6 \\
\hline & & & 4 & $0,5-0,5$ & 14 \\
\hline & & & 5 & $0,5-0,5$ & 11 \\
\hline & & & 6 & $0,3-0,3$ & 27 \\
\hline & & & 7 & $0,4-0,4$ & 58 \\
\hline & & & 8 & $0,6-0,7$ & 14 \\
\hline \multirow[t]{8}{*}{223} & 182,6 & 180,21 & 1 & $0,9-0,9$ & 2 \\
\hline & & & 2 & $0,5-0,5$ & 11 \\
\hline & & & 3 & $0,5-0,5$ & 4 \\
\hline & & & 4 & $0,8-0,8$ & 3 \\
\hline & & & 5 & $0,8-0,8$ & 2 \\
\hline & & & 6 & $0,6-0,5$ & 3 \\
\hline & & & 7 & $0,6-0,6$ & 6 \\
\hline & & & 8 & $0,9-0,9$ & 2 \\
\hline \multirow[t]{8}{*}{224} & 183,86 & 182,18 & 1 & $1,0-1,0$ & 3 \\
\hline & & & 2 & $0,6-0,6$ & 3 \\
\hline & & & 3 & $0,5-0,5$ & 4 \\
\hline & & & 4 & $0,8-1$ & 4 \\
\hline & & & 5 & $0,7-0,8$ & 6 \\
\hline & & & 6 & $0,8-0,8$ & 5 \\
\hline & & & 7 & $0,3-0,3$ & 2 \\
\hline & & & 8 & $0,5-0,5$ & 3 \\
\hline \multirow[t]{8}{*}{225} & 182,44 & 180,74 & 1 & $0,8-0,7$ & 4 \\
\hline & & & 2 & $1-1,1$ & 2 \\
\hline & & & 3 & $0,8-1,1$ & 1 \\
\hline & & & 4 & $0,5-0,7$ & 3 \\
\hline & & & 5 & $0,7-0,5$ & 5 \\
\hline & & & 6 & $1,2-1,2$ & 1 \\
\hline & & & 7 & $0,5-0,7$ & 1 \\
\hline & & & 8 & $0,8-0,8$ & 3 \\
\hline \multirow[t]{5}{*}{226} & 167,62 & 166,32 & 1 & $1-1,1$ & 4 \\
\hline & & & 2 & $0,3-0,5$ & 1 \\
\hline & & & 3 & $0,5-0,5$ & 2 \\
\hline & & & 4 & $1-1,1$ & 3 \\
\hline & & & 5 & $0,9-1$ & 2 \\
\hline
\end{tabular}




\begin{tabular}{l|l|l|l|l|l} 
& & & 6 & $0,5-0,7$ & 2 \\
\hline & & & 7 & $1,1-1$ & 4 \\
\hline 227 & 167,03 & 165,24 & 1 & $0,6-0,6$ & 1 \\
\hline & & & 2 & $0,6-0,5$ & 3 \\
\hline & & & 2 & $0,9-1$ & 2 \\
\hline & & & 3 & $0,8-0,8$ & 5 \\
\hline & & & 4 & $0,6-0,7$ & 3 \\
\hline & & & 5 & $0,8-0,8$ & 2 \\
\hline & & & 6 & $0,5-0,5$ & 4 \\
\hline & & & 7 & $0,9-1,1$ & 5 \\
\hline & 181,73 & 180,56 & 8 & $0,8-0,7$ & 5 \\
\hline & & & 1 & $0,5-0,6$ & 3 \\
\hline & & & 2 & $0,8-1$ & 2 \\
\hline & & & 3 & $1,6-0,7$ & 3 \\
\hline & & & 4 & $0,5-0,4$ & 4 \\
\hline & & & 5 & $0,6-0,8$ & 5 \\
\hline & & & 6 & $0,7-0,7$ & 5 \\
\hline
\end{tabular}

B. Estudio de lesiones en hojas del segundo muestreo (T1)

\begin{tabular}{|c|c|c|c|c|c|}
\hline Taqman & peso antes (g) & $\begin{array}{c}\text { peso } \\
\text { después }(\mathrm{g})\end{array}$ & lesión & medida $(\mathrm{cm})$ & $\begin{array}{l}\text { lesiones } \\
\text { totales }\end{array}$ \\
\hline \multirow[t]{8}{*}{1} & 109,6 & 107,64 & 1 & $1.0-1.0$ & 177 \\
\hline & & & 2 & $1-0.8$ & 43 \\
\hline & & & 3 & $1.5-0.8$ & 50 \\
\hline & & & 4 & $1-1.5$ & 1000 \\
\hline & & & 5 & $0.7-0.7$ & 33 \\
\hline & & & 6 & $1-1.5$ & 32 \\
\hline & & & 7 & $0.4-0.8$ & 74 \\
\hline & & & 8 & $0.7-0.8$ & 27 \\
\hline \multirow[t]{8}{*}{5} & 109,1 & 106,59 & 1 & $0.5-0.6$ & 25 \\
\hline & & & 2 & $1.1-1$ & 51 \\
\hline & & & 3 & $1.1-1.2$ & 7 \\
\hline & & & 4 & $1-0.8$ & 15 \\
\hline & & & 5 & $0.7-1$ & 5 \\
\hline & & & 6 & $0.6-0.9$ & 7 \\
\hline & & & 7 & $0.8-0.8$ & 78 \\
\hline & & & 8 & $0.8-0.9$ & 88 \\
\hline 9 & 115,28 & 113,19 & 1 & $0.8-1.6$ & 36 \\
\hline
\end{tabular}




\begin{tabular}{|c|c|c|c|c|c|}
\hline & & & 2 & $0.5-1$ & 49 \\
\hline & & & 3 & $0.5-0.7$ & 9 \\
\hline & & & 4 & $0.5-0.5$ & 6 \\
\hline & & & 5 & $0.7-0.9$ & 29 \\
\hline & & & 6 & $0.5-0.7$ & 25 \\
\hline & & & 7 & $0.6-1$ & 65 \\
\hline & & & 8 & $0.7-0.8$ & 35 \\
\hline \multirow[t]{8}{*}{13} & 93,27 & 92,23 & 1 & $0.6-1$ & 48 \\
\hline & & & 2 & $0.6-1.1$ & 8 \\
\hline & & & 3 & $0.5-1.1$ & 12 \\
\hline & & & 4 & $1.0-1.0$ & 98 \\
\hline & & & 5 & $0.5-1.1$ & 19 \\
\hline & & & 6 & $1.0-1.0$ & 110 \\
\hline & & & 7 & 1.3-1.1 & 103 \\
\hline & & & 8 & $0.5-0.5$ & 33 \\
\hline \multirow[t]{8}{*}{17} & 88,2 & 86,9 & 1 & $0.7-0.8$ & 97 \\
\hline & & & 2 & $0.6-1$ & 58 \\
\hline & & & 3 & $0.7-1$ & 32 \\
\hline & & & 4 & $0.8-1.2$ & 16 \\
\hline & & & 5 & $0.6-0.7$ & 16 \\
\hline & & & 6 & 1.0-1.0 & 37 \\
\hline & & & 7 & $0.6-0.6$ & 27 \\
\hline & & & 8 & $1.0-1.0$ & 2 \\
\hline \multirow[t]{8}{*}{21} & 97,5 & 96,14 & 1 & $0.6-0.7$ & 30 \\
\hline & & & 2 & $0.9-0.9$ & 22 \\
\hline & & & 3 & $0.6-0.7$ & 24 \\
\hline & & & 4 & $1-0.8$ & 10 \\
\hline & & & 5 & $0.7-0.7$ & 48 \\
\hline & & & 6 & $0.8-0.6$ & 400 \\
\hline & & & 7 & $0.6-0.6$ & 79 \\
\hline & & & 8 & $0.5-0.6$ & 200 \\
\hline \multirow[t]{2}{*}{25} & 26,03 & 25,54 & 1 & $0.8-1.2$ & 38 \\
\hline & & & 2 & $0.9-1$ & 1000 \\
\hline \multirow[t]{2}{*}{26} & 36,47 & 35,57 & 1 & $0.7-1$ & 59 \\
\hline & & & 2 & $1.0-1.0$ & 76 \\
\hline \multirow[t]{2}{*}{27} & 38,66 & 37,43 & 1 & $0.6-0.6$ & 49 \\
\hline & & & 2 & $1-1.2$ & 87 \\
\hline \multirow[t]{5}{*}{37} & 147,81 & 145,24 & 1 & $0.5-1$ & 30 \\
\hline & & & 2 & $0.7-0.8$ & 29 \\
\hline & & & 3 & $1-0.7$ & 2 \\
\hline & & & 4 & $0.8-1$ & 1 \\
\hline & & & 5 & 1.3-1.5 & 8 \\
\hline
\end{tabular}




\begin{tabular}{|c|c|c|c|c|c|}
\hline & & & 6 & $0.6-1$ & 9 \\
\hline & & & 7 & $1.0-2$ & 6 \\
\hline & & & 8 & $1-1.8$ & 3 \\
\hline \multirow[t]{8}{*}{41} & 140,52 & 137,77 & 1 & $0.7-0.8$ & 1 \\
\hline & & & 2 & $0.9-0.7$ & 3 \\
\hline & & & 3 & 1.3-1 & 1 \\
\hline & & & 4 & $0.7-1.5$ & 2 \\
\hline & & & 5 & $1-0.5$ & 2 \\
\hline & & & 6 & $1.0-1.0$ & 2 \\
\hline & & & 7 & $0.7-0.5$ & 3 \\
\hline & & & 8 & $0.5-1$ & 1 \\
\hline \multirow[t]{8}{*}{45} & 92,9 & 90,11 & 1 & $1.3-1.3$ & 1 \\
\hline & & & 2 & $0.7-0.8$ & 4 \\
\hline & & & 3 & $0.9-0.9$ & 2 \\
\hline & & & 4 & 0.9-1 & 4 \\
\hline & & & 5 & 1.0-1.0 & 5 \\
\hline & & & 6 & $0.5-0.5$ & 50 \\
\hline & & & 7 & $1-0.7$ & 3 \\
\hline & & & 8 & $1.0-1.0$ & 7 \\
\hline \multirow[t]{8}{*}{49} & 134,51 & 132,31 & 1 & $1.0-1.0$ & 5 \\
\hline & & & 2 & 1.2-1.2 & 4 \\
\hline & & & 3 & $1-1.3$ & 10 \\
\hline & & & 4 & 0.7-1.2 & 4 \\
\hline & & & 5 & 1.1-1.3 & 2 \\
\hline & & & 6 & $1-0.8$ & 2 \\
\hline & & & 7 & 1.0-1.0 & 3 \\
\hline & & & 8 & $3-0.7$ & 6 \\
\hline \multirow[t]{8}{*}{53} & 131,47 & 129,13 & 1 & 1.0-1.0 & 2 \\
\hline & & & 2 & $0.8-1$ & 1 \\
\hline & & & 3 & $1-0.5$ & 1 \\
\hline & & & 4 & $1.2-1.3$ & 2 \\
\hline & & & 5 & 1.1-1.2 & 4 \\
\hline & & & 6 & $0.7-1.3$ & 2 \\
\hline & & & 7 & $1.0-1.0$ & 8 \\
\hline & & & 8 & $1.5-1.5$ & 5 \\
\hline \multirow[t]{7}{*}{57} & 135,41 & 133,37 & 1 & $1-0.7$ & 3 \\
\hline & & & 2 & $0.8-0.3$ & 1 \\
\hline & & & 3 & $1-1.2$ & 2 \\
\hline & & & 4 & $0.7-1$ & 1 \\
\hline & & & 5 & 1.3-1.5 & 2 \\
\hline & & & 6 & $1.0-1.0$ & 3 \\
\hline & & & 7 & $1.0-1.0$ & 5 \\
\hline
\end{tabular}




\begin{tabular}{|c|c|c|c|c|c|}
\hline & & & 8 & $1-1.2$ & 1 \\
\hline \multirow[t]{2}{*}{61} & 37,12 & 36,59 & 1 & $0.6-1$ & 4 \\
\hline & & & 2 & $1.0-1.0$ & 4 \\
\hline \multirow[t]{2}{*}{62} & 38,02 & 37,71 & 1 & $1-1.1$ & 4 \\
\hline & & & 2 & $1-1.2$ & 5 \\
\hline \multirow[t]{2}{*}{63} & 25,25 & 24,94 & 1 & 0.8-1 & 2 \\
\hline & & & 2 & $1.2-1.2$ & 3 \\
\hline \multirow[t]{8}{*}{73} & 89,98 & 88,39 & 1 & $0.6-0.5$ & 75 \\
\hline & & & 2 & $0.6-0.5$ & 34 \\
\hline & & & 3 & $0.6-0.6$ & 93 \\
\hline & & & 4 & $0.6-0.6$ & 27 \\
\hline & & & 5 & $1-1.2$ & 85 \\
\hline & & & 6 & $1-0.8$ & 102 \\
\hline & & & 7 & $0.7-0.7$ & 40 \\
\hline & & & 8 & $1-1.1$ & 141 \\
\hline \multirow[t]{8}{*}{77} & 105,23 & 104,47 & 1 & $1-0.7$ & 8 \\
\hline & & & 2 & $0.8-1$ & 36 \\
\hline & & & 3 & $0.6-0.7$ & 73 \\
\hline & & & 4 & $0.7-0.8$ & 23 \\
\hline & & & 5 & $0.7-0.7$ & 94 \\
\hline & & & 6 & $0.8-0.7$ & 54 \\
\hline & & & 7 & $0.7-0.7$ & 34 \\
\hline & & & 8 & $0.7-1$ & 59 \\
\hline \multirow[t]{8}{*}{81} & 110,6 & 109,7 & 1 & $0.6-0.9$ & 12 \\
\hline & & & 2 & $0.7-0.9$ & 6 \\
\hline & & & 3 & $1-0.5$ & 3 \\
\hline & & & 4 & $0.6-0.7$ & 43 \\
\hline & & & 5 & $0.6-0.7$ & 25 \\
\hline & & & 6 & $0.7-0.7$ & 47 \\
\hline & & & 7 & 1.0-1.0 & 105 \\
\hline & & & 8 & $0.5-0.5$ & 30 \\
\hline \multirow[t]{8}{*}{85} & 96,67 & 95,71 & 1 & $0.7-0.8$ & 12 \\
\hline & & & 2 & $0.5-0.4$ & 36 \\
\hline & & & 3 & $0.7-0.7$ & 112 \\
\hline & & & 4 & $1.0-1.0$ & 19 \\
\hline & & & 5 & $0.8-1.2$ & 86 \\
\hline & & & 6 & $0.5-0.5$ & 1000 \\
\hline & & & 7 & $0.7-0.8$ & 13 \\
\hline & & & 8 & $1.0-1.0$ & 19 \\
\hline \multirow[t]{3}{*}{89} & 124 & 122,9 & 1 & $0.7-0.5$ & 7 \\
\hline & & & 2 & $0.8-0.5$ & 24 \\
\hline & & & 3 & $0.6-0.5$ & 20 \\
\hline
\end{tabular}




\begin{tabular}{|c|c|c|c|c|c|}
\hline & & & 4 & $0.6-0.8$ & 43 \\
\hline & & & 5 & $0.7-0.8$ & 9 \\
\hline & & & 6 & $0.5-0.6$ & 68 \\
\hline & & & 7 & $0.7-0.8$ & 130 \\
\hline & & & 8 & $0.7-0.7$ & 17 \\
\hline \multirow[t]{8}{*}{93} & 96,23 & 95,31 & 1 & $0.6-1$ & 20 \\
\hline & & & 2 & $1.0-1.0$ & 51 \\
\hline & & & 3 & $0.6-0.6$ & 15 \\
\hline & & & 4 & $0.6-0.7$ & 3 \\
\hline & & & 5 & $0.8-1$ & 56 \\
\hline & & & 6 & $0.6-0.6$ & 18 \\
\hline & & & 7 & $0.6-0.8$ & 500 \\
\hline & & & 8 & $1.0-1.0$ & 3 \\
\hline \multirow[t]{2}{*}{97} & 25,89 & 25,75 & 1 & $0.7-0.7$ & 1 \\
\hline & & & 2 & $0.8-1$ & 51 \\
\hline \multirow[t]{2}{*}{98} & 31,23 & 30,78 & 1 & $1-1.2$ & 12 \\
\hline & & & 2 & $1.0-1.0$ & 60 \\
\hline \multirow[t]{2}{*}{99} & 29,35 & 29,32 & 1 & $0.8-0.5$ & 20 \\
\hline & & & 2 & $1.0-1.0$ & 75 \\
\hline \multirow[t]{8}{*}{109} & 145,99 & 144,54 & 1 & $1-1.2$ & 27 \\
\hline & & & 2 & $0.8-1$ & 1 \\
\hline & & & 3 & $1.5-1.5$ & 5 \\
\hline & & & 4 & $1.0-1.0$ & 4 \\
\hline & & & 5 & 1.3-1.3 & 7 \\
\hline & & & 6 & $0.8-0.8$ & 6 \\
\hline & & & 7 & $0.5-0.7$ & 2 \\
\hline & & & 8 & $0.6-0.6$ & 4 \\
\hline \multirow[t]{8}{*}{113} & 124,74 & 123,25 & 1 & $0.5-0.8$ & 3 \\
\hline & & & 2 & $0.8-0.5$ & 1 \\
\hline & & & 3 & $1.0-1.0$ & 3 \\
\hline & & & 4 & $1.0-1.0$ & 5 \\
\hline & & & 5 & $0.7-0.9$ & 6 \\
\hline & & & 6 & $1.4-2$ & 3 \\
\hline & & & 7 & $0.8-2.1$ & 2 \\
\hline & & & 8 & $1.2-1$ & 6 \\
\hline \multirow[t]{7}{*}{117} & 128,74 & 127,07 & 1 & $0.9-1.1$ & 4 \\
\hline & & & 2 & $0.5-0.3$ & 2 \\
\hline & & & 3 & $0.3-0.5$ & 5 \\
\hline & & & 4 & $0.7-0.8$ & 1 \\
\hline & & & 5 & $0.7-0.8$ & 2 \\
\hline & & & 6 & $1.1-1$ & 2 \\
\hline & & & 7 & $1.0-1.0$ & 2 \\
\hline
\end{tabular}




\begin{tabular}{|c|c|c|c|c|c|}
\hline & & & 8 & $1.2-1.5$ & 5 \\
\hline \multirow[t]{8}{*}{121} & 128,61 & 127,8 & 1 & $1.0-1.0$ & 8 \\
\hline & & & 2 & $0.6-0.8$ & 11 \\
\hline & & & 3 & $0.8-0.8$ & 6 \\
\hline & & & 4 & $1-0.8$ & 1 \\
\hline & & & 5 & $0.8-1.1$ & 4 \\
\hline & & & 6 & $0.8-0.7$ & 2 \\
\hline & & & 7 & $0.5-0.6$ & 6 \\
\hline & & & 8 & $0.7-0.8$ & 3 \\
\hline \multirow[t]{8}{*}{125} & 138,16 & 136,08 & 1 & $0.6-0.5$ & 3 \\
\hline & & & 2 & 1.3-1.6 & 4 \\
\hline & & & 3 & $1.1-0.8$ & 5 \\
\hline & & & 4 & $1.2-1$ & 3 \\
\hline & & & 5 & $1.0-1.0$ & 4 \\
\hline & & & 6 & $0.4-1$ & 2 \\
\hline & & & 7 & $1-1.1$ & 3 \\
\hline & & & 8 & $1-1.1$ & 4 \\
\hline \multirow[t]{8}{*}{129} & 138,2 & 135,83 & 1 & $0.7-0.7$ & 5 \\
\hline & & & 2 & $0.8-0.9$ & 7 \\
\hline & & & 3 & $1-0.8$ & 3 \\
\hline & & & 4 & $0.7-0.7$ & 2 \\
\hline & & & 5 & $0.6-0.8$ & 3 \\
\hline & & & 6 & $1.0-1.0$ & 7 \\
\hline & & & 7 & $1.0-1.0$ & 1 \\
\hline & & & 8 & $0.6-0.7$ & 1 \\
\hline \multirow[t]{2}{*}{133} & 34,31 & 33,84 & 1 & $0.5-0.8$ & 4 \\
\hline & & & 2 & 1.3-1.5 & 1 \\
\hline \multirow[t]{2}{*}{134} & 39,79 & 38,97 & 1 & 1.3-1.6 & 1 \\
\hline & & & 2 & $1-1.1$ & 3 \\
\hline \multirow[t]{2}{*}{135} & 41,47 & 40,93 & 1 & $1-0.8$ & 7 \\
\hline & & & 2 & 1.2-1.2 & 3 \\
\hline \multirow[t]{8}{*}{145} & 104,2 & 103,08 & 1 & $0.2-0.3$ & 131 \\
\hline & & & 2 & $1.0-1.0$ & 33 \\
\hline & & & 3 & $0.6-0.5$ & 9 \\
\hline & & & 4 & $1.0-1.0$ & 58 \\
\hline & & & 5 & $0.6-0.7$ & 54 \\
\hline & & & 6 & $0.5-0.5$ & 29 \\
\hline & & & 7 & $0.8-1$ & 48 \\
\hline & & & 8 & $0.5-0.5$ & 12 \\
\hline \multirow[t]{3}{*}{149} & 95,72 & 94,92 & 1 & $0.7-0.6$ & 3 \\
\hline & & & 2 & $1-0.8$ & 7 \\
\hline & & & 3 & $0.6-0.6$ & 9 \\
\hline
\end{tabular}




\begin{tabular}{|c|c|c|c|c|c|}
\hline & & & 4 & $0.6-1.1$ & 4 \\
\hline & & & 5 & $0.7-0.8$ & 3 \\
\hline & & & 6 & $0.6-0.7$ & 31 \\
\hline & & & 7 & $0.6-0.7$ & 21 \\
\hline & & & 8 & $0.7-0.6$ & 17 \\
\hline \multirow[t]{8}{*}{153} & 92,71 & 91,78 & 1 & $0.7-0.8$ & 19 \\
\hline & & & 2 & $0.5-0.5$ & 43 \\
\hline & & & 3 & $0.5-0.5$ & 6 \\
\hline & & & 4 & $0.7-0.7$ & 24 \\
\hline & & & 5 & $0.6-0.6$ & 47 \\
\hline & & & 6 & $0.7-1$ & 63 \\
\hline & & & 7 & $0.7-0.7$ & 35 \\
\hline & & & 8 & $0.7-0.4$ & 23 \\
\hline \multirow[t]{8}{*}{157} & 88,89 & 87,84 & 1 & $0.6-0.8$ & 20 \\
\hline & & & 2 & $0.6-0.6$ & 53 \\
\hline & & & 3 & $0.3-0.4$ & 18 \\
\hline & & & 4 & $1-0.8$ & 26 \\
\hline & & & 5 & $0.6-0.6$ & 220 \\
\hline & & & 6 & $0.8-0.7$ & 15 \\
\hline & & & 7 & $0.5-0.5$ & 200 \\
\hline & & & 8 & $0.8-0.8$ & 1000 \\
\hline \multirow[t]{8}{*}{161} & 104,56 & 103,79 & 1 & $0.6-0.7$ & 4 \\
\hline & & & 2 & $0.7-1$ & 23 \\
\hline & & & 3 & $0.5-0.5$ & 46 \\
\hline & & & 4 & 1.1-1.1 & 43 \\
\hline & & & 5 & $0.7-0.7$ & 14 \\
\hline & & & 6 & $1.0-1.0$ & 11 \\
\hline & & & 7 & $0.5-0.3$ & 3 \\
\hline & & & 8 & $0.5-0.5$ & 17 \\
\hline \multirow[t]{8}{*}{165} & 94,23 & 93,56 & 1 & $0.5-0.5$ & 35 \\
\hline & & & 2 & $0.7-0.7$ & 24 \\
\hline & & & 3 & $0.9-0.9$ & 45 \\
\hline & & & 4 & $1-1.1$ & 16 \\
\hline & & & 5 & $0.5-0.5$ & 7 \\
\hline & & & 6 & $0.5-0.5$ & 31 \\
\hline & & & 7 & $0.6-0.6$ & 11 \\
\hline & & & 8 & $0.7-0.8$ & 46 \\
\hline \multirow[t]{2}{*}{169} & 26,84 & 26,7 & 1 & $1.0-1.0$ & 1000 \\
\hline & & & 2 & $0.5-0.5$ & 15 \\
\hline \multirow[t]{2}{*}{170} & 24,94 & 24 & 1 & $0.5-0.5$ & 10 \\
\hline & & & 2 & $0.7-1.1$ & 17 \\
\hline 171 & 40,68 & 40,08 & 1 & $1.5-1.3$ & 65 \\
\hline
\end{tabular}




\begin{tabular}{|c|c|c|c|c|c|}
\hline & & & 2 & $1.3-1$ & 18 \\
\hline \multirow[t]{8}{*}{181} & 141,56 & 140 & 1 & $0.3-0.2$ & 2 \\
\hline & & & 2 & $0.5-0.5$ & 1 \\
\hline & & & 3 & $0.8-0.5$ & 4 \\
\hline & & & 4 & $0.7-0.7$ & 2 \\
\hline & & & 5 & $0.6-1$ & 1 \\
\hline & & & 6 & $0.7-0.7$ & 9 \\
\hline & & & 7 & $0.7-0.7$ & 7 \\
\hline & & & 8 & $1.0-1.0$ & 7 \\
\hline \multirow[t]{8}{*}{185} & 132,83 & 131,48 & 1 & $0.4-1.5$ & 1 \\
\hline & & & 2 & $0.7-0.3$ & 9 \\
\hline & & & 3 & $1.1-1$ & 3 \\
\hline & & & 4 & $1-1.2$ & 3 \\
\hline & & & 5 & $1.2-1$ & 2 \\
\hline & & & 6 & $1.2-1$ & 6 \\
\hline & & & 7 & $0.8-1$ & 2 \\
\hline & & & 8 & $0.6-0.6$ & 2 \\
\hline \multirow[t]{8}{*}{189} & 130,28 & 128,51 & 1 & $0.6-0.6$ & 2 \\
\hline & & & 2 & $1-1.2$ & 4 \\
\hline & & & 3 & $0.7-0.7$ & 1 \\
\hline & & & 4 & $0.6-1$ & 1 \\
\hline & & & 5 & $1-1.1$ & 1 \\
\hline & & & 6 & $0.5-0.5$ & 1 \\
\hline & & & 7 & $0.6-1.2$ & 1 \\
\hline & & & 8 & $0.6-0.7$ & 2 \\
\hline \multirow[t]{8}{*}{193} & 168,7 & 166,93 & 1 & 1.2-1.2 & 3 \\
\hline & & & 2 & $0.6-0.6$ & 4 \\
\hline & & & 3 & $1.0-1.0$ & 2 \\
\hline & & & 4 & $0.8-1$ & 5 \\
\hline & & & 5 & 1.2-1.3 & 3 \\
\hline & & & 6 & $1.3-2$ & 3 \\
\hline & & & 7 & $0.9-1$ & 2 \\
\hline & & & 8 & $0.9-1$ & 1 \\
\hline \multirow[t]{8}{*}{197} & 131,33 & 130,53 & 1 & $1.2-1$ & 2 \\
\hline & & & 2 & $0.7-0.7$ & 2 \\
\hline & & & 3 & $0.6-0.7$ & 1 \\
\hline & & & 4 & $0.8-1$ & 1 \\
\hline & & & 5 & $0.8-0.8$ & 3 \\
\hline & & & 6 & $1-0.9$ & 3 \\
\hline & & & 7 & $0.6-0.6$ & 4 \\
\hline & & & 8 & $0.7-1.2$ & 3 \\
\hline 201 & 166,78 & 165,59 & 1 & 1.1-1.2 & 13 \\
\hline
\end{tabular}




\begin{tabular}{c|c|c|c|c|c} 
& & & 2 & $1.1-1.1$ & 11 \\
\hline & & & 3 & $0.6-0.6$ & 4 \\
\hline & & & 4 & $0.6-0.7$ & 2 \\
\hline & & & 5 & $1.0-1.0$ & 3 \\
\hline & & & 6 & $0.5-0.6$ & 9 \\
\hline & & & 7 & $0.6-0.8$ & 2 \\
\hline & & & 8 & $1.5-1.3$ & 4 \\
\hline 205 & 43,92 & 43,59 & 1 & $1.0-1.0$ & 1 \\
\hline 206 & & & 2 & $1.0-1.0$ & 2 \\
\hline & 42,02 & 41,65 & 1 & $1.1-1$ & 3 \\
\hline 207 & 26,2 & 25,46 & 1 & $1.5-1.8$ & 3 \\
\hline & & & 2 & $1.5-1.1$ & 2 \\
\hline
\end{tabular}





\section{ANEJO 4}

A. Conteo de esporas en el primer muestreo (T0)

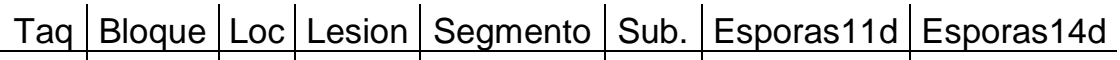

\begin{tabular}{|c|c|c|c|c|c|c|c|}
\hline 217 & Block 1 & $A$ & 1 & $a$ & 1 & & \\
\hline & & & & $a$ & 2 & & \\
\hline & & & & $b$ & 1 & & \\
\hline & & & & $b$ & 2 & & \\
\hline & & & & C & 1 & & \\
\hline & & & & c & 2 & & \\
\hline & & & & $d$ & 1 & & \\
\hline & & & & $d$ & 2 & & \\
\hline 217 & Block 1 & $A$ & 2 & $a$ & 1 & 2 & 14 \\
\hline & & & & $a$ & 2 & 0 & 0 \\
\hline & & & & $b$ & 1 & 0 & 387 \\
\hline & & & & $b$ & 2 & 0 & 5 \\
\hline & & & & $\mathrm{C}$ & 1 & 27 & 2 \\
\hline & & & & C & 2 & 13 & 0 \\
\hline & & & & $d$ & 1 & 309 & 5 \\
\hline & & & & $d$ & 2 & 657 & 0 \\
\hline 217 & Block 1 & $A$ & 3 & $a$ & 1 & 0 & 253 \\
\hline & & & & $a$ & 2 & 1 & 273 \\
\hline & & & & $b$ & 1 & 0 & 4 \\
\hline & & & & $b$ & 2 & 0 & 6 \\
\hline & & & & C & 1 & 0 & 247 \\
\hline & & & & $c$ & 2 & 0 & 145 \\
\hline & & & & $d$ & 1 & 0 & 39 \\
\hline & & & & $d$ & 2 & 0 & 24 \\
\hline 217 & Block 1 & $\mathrm{~A}$ & 4 & $a$ & 1 & & \\
\hline & & & & $a$ & 2 & & \\
\hline & & & & $b$ & 1 & & \\
\hline & & & & $b$ & 2 & & \\
\hline & & & & C & 1 & & \\
\hline & & & & C & 2 & & \\
\hline & & & & $d$ & 1 & & \\
\hline & & & & $d$ & 2 & & \\
\hline 217 & Block 1 & $A$ & 5 & $a$ & 1 & & \\
\hline & & & & $\mathrm{a}$ & 2 & & \\
\hline
\end{tabular}




\begin{tabular}{|c|c|c|c|c|c|c|c|}
\hline & & & & $b$ & 1 & & \\
\hline & & & & $b$ & 2 & & \\
\hline & & & & C & 1 & & \\
\hline & & & & C & 2 & & \\
\hline & & & & $d$ & 1 & & \\
\hline & & & & $d$ & 2 & & \\
\hline \multirow[t]{8}{*}{217} & Block 1 & A & 6 & $\mathrm{a}$ & 1 & 324 & 290 \\
\hline & & & & a & 2 & 45 & 65 \\
\hline & & & & $b$ & 1 & 214 & 31 \\
\hline & & & & $b$ & 2 & 25 & 7 \\
\hline & & & & $\mathrm{C}$ & 1 & 21 & 28 \\
\hline & & & & $C$ & 2 & 2 & 6 \\
\hline & & & & $d$ & 1 & 114 & 195 \\
\hline & & & & $d$ & 2 & 7 & 79 \\
\hline \multirow[t]{8}{*}{217} & Block 1 & A & 7 & $\mathrm{a}$ & 1 & 79 & 117 \\
\hline & & & & $\mathrm{a}$ & 2 & 2 & 41 \\
\hline & & & & $b$ & 1 & 643 & 32 \\
\hline & & & & $b$ & 2 & 82 & 10 \\
\hline & & & & $C$ & 1 & 200 & 123 \\
\hline & & & & $\mathrm{C}$ & 2 & 304 & 106 \\
\hline & & & & $d$ & 1 & 170 & 84 \\
\hline & & & & $d$ & 2 & 64 & 110 \\
\hline \multirow[t]{8}{*}{217} & Block 1 & A & 8 & $\mathrm{a}$ & 1 & & \\
\hline & & & & $a$ & 2 & & \\
\hline & & & & $b$ & 1 & & \\
\hline & & & & $b$ & 2 & & \\
\hline & & & & $\mathrm{C}$ & 1 & & \\
\hline & & & & C & 2 & & \\
\hline & & & & $d$ & 1 & & \\
\hline & & & & $d$ & 2 & & \\
\hline \multirow[t]{8}{*}{219} & Block 2 & A & 1 & a & 1 & & \\
\hline & & & & a & 2 & & \\
\hline & & & & $\mathrm{b}$ & 1 & & \\
\hline & & & & $b$ & 2 & & \\
\hline & & & & $\mathrm{C}$ & 1 & & \\
\hline & & & & $C$ & 2 & & \\
\hline & & & & $d$ & 1 & & \\
\hline & & & & $d$ & 2 & & \\
\hline \multirow[t]{3}{*}{219} & Block 2 & A & 2 & $\mathrm{a}$ & 1 & 567 & 349 \\
\hline & & & & $\mathrm{a}$ & 2 & 1156 & 505 \\
\hline & & & & $b$ & 1 & 237 & 237 \\
\hline
\end{tabular}




\begin{tabular}{|c|c|c|c|c|c|c|c|}
\hline & & & & $b$ & 2 & 227 & 174 \\
\hline & & & & $c$ & 1 & 53 & 101 \\
\hline & & & & c & 2 & 26 & 57 \\
\hline & & & & $d$ & 1 & 176 & 214 \\
\hline & & & & $d$ & 2 & 25 & 99 \\
\hline \multirow[t]{8}{*}{219} & Block 2 & $A$ & 3 & $a$ & 1 & & \\
\hline & & & & $a$ & 2 & & \\
\hline & & & & $b$ & 1 & & \\
\hline & & & & $b$ & 2 & & \\
\hline & & & & C & 1 & & \\
\hline & & & & $c$ & 2 & & \\
\hline & & & & $d$ & 1 & & \\
\hline & & & & $d$ & 2 & & \\
\hline \multirow[t]{8}{*}{219} & Block 2 & $A$ & 4 & $a$ & 1 & 250 & 18 \\
\hline & & & & $a$ & 2 & 66 & 16 \\
\hline & & & & $b$ & 1 & 110 & 0 \\
\hline & & & & $b$ & 2 & 2 & 0 \\
\hline & & & & $\mathrm{C}$ & 1 & 29 & 0 \\
\hline & & & & C & 2 & 0 & 0 \\
\hline & & & & $d$ & 1 & 127 & 0 \\
\hline & & & & $d$ & 2 & 55 & 0 \\
\hline \multirow[t]{8}{*}{219} & Block 2 & $A$ & 5 & $a$ & 1 & & \\
\hline & & & & $a$ & 2 & & \\
\hline & & & & $b$ & 1 & & \\
\hline & & & & $\mathrm{b}$ & 2 & & \\
\hline & & & & C & 1 & & \\
\hline & & & & C & 2 & & \\
\hline & & & & $d$ & 1 & & \\
\hline & & & & $d$ & 2 & & \\
\hline \multirow[t]{8}{*}{219} & Block 2 & $A$ & 6 & $a$ & 1 & & \\
\hline & & & & $\mathrm{a}$ & 2 & & \\
\hline & & & & $b$ & 1 & & \\
\hline & & & & $\mathrm{b}$ & 2 & & \\
\hline & & & & $c$ & 1 & & \\
\hline & & & & C & 2 & & \\
\hline & & & & $d$ & 1 & & \\
\hline & & & & $d$ & 2 & & \\
\hline \multirow[t]{4}{*}{219} & Block 2 & $A$ & 7 & $a$ & 1 & & \\
\hline & & & & $a$ & 2 & & \\
\hline & & & & $b$ & 1 & & \\
\hline & & & & $\mathrm{b}$ & 2 & & \\
\hline
\end{tabular}




\begin{tabular}{|c|c|c|c|c|c|c|c|}
\hline & & & & $\mathrm{C}$ & 1 & & \\
\hline & & & & C & 2 & & \\
\hline & & & & $d$ & 1 & & \\
\hline & & & & $d$ & 2 & & \\
\hline \multirow[t]{8}{*}{219} & Block 2 & A & 8 & $a$ & 1 & & \\
\hline & & & & a & 2 & & \\
\hline & & & & $b$ & 1 & & \\
\hline & & & & $b$ & 2 & & \\
\hline & & & & $\mathrm{C}$ & 1 & & \\
\hline & & & & C & 2 & & \\
\hline & & & & $d$ & 1 & & \\
\hline & & & & $d$ & 2 & & \\
\hline \multirow[t]{8}{*}{221} & Block 3 & A & 1 & $a$ & 1 & & \\
\hline & & & & $a$ & 2 & & \\
\hline & & & & $b$ & 1 & & \\
\hline & & & & $b$ & 2 & & \\
\hline & & & & $\mathrm{C}$ & 1 & & \\
\hline & & & & C & 2 & & \\
\hline & & & & $\mathrm{d}$ & 1 & & \\
\hline & & & & $\mathrm{d}$ & 2 & & \\
\hline \multirow[t]{8}{*}{221} & Block 3 & A & 2 & $a$ & 1 & 0 & 17 \\
\hline & & & & $\mathrm{a}$ & 2 & 0 & 14 \\
\hline & & & & $b$ & 1 & 0 & 4 \\
\hline & & & & $b$ & 2 & 0 & 0 \\
\hline & & & & $C$ & 1 & 0 & 11 \\
\hline & & & & $C$ & 2 & 0 & 0 \\
\hline & & & & $d$ & 1 & 0 & 30 \\
\hline & & & & $d$ & 2 & 0 & 11 \\
\hline \multirow[t]{8}{*}{221} & Block 3 & A & 3 & $a$ & 1 & & \\
\hline & & & & $\mathrm{a}$ & 2 & & \\
\hline & & & & $b$ & 1 & & \\
\hline & & & & $b$ & 2 & & \\
\hline & & & & $\mathrm{C}$ & 1 & & \\
\hline & & & & $C$ & 2 & & \\
\hline & & & & $d$ & 1 & & \\
\hline & & & & $d$ & 2 & & \\
\hline \multirow[t]{5}{*}{221} & Block 3 & $A$ & 4 & $\mathrm{a}$ & 1 & 0 & 0 \\
\hline & & & & $\mathrm{a}$ & 2 & 0 & 0 \\
\hline & & & & $b$ & 1 & 0 & 2 \\
\hline & & & & $b$ & 2 & 0 & 1 \\
\hline & & & & C & 1 & 3 & 1 \\
\hline
\end{tabular}




\begin{tabular}{|c|c|c|c|c|c|c|c|}
\hline & & & & $\mathrm{C}$ & 2 & 2 & 2 \\
\hline & & & & $d$ & 1 & 0 & 0 \\
\hline & & & & $d$ & 2 & 0 & 0 \\
\hline \multirow[t]{8}{*}{221} & Block 3 & $A$ & 5 & $\mathrm{a}$ & 1 & 0 & 0 \\
\hline & & & & $\mathrm{a}$ & 2 & 0 & 0 \\
\hline & & & & $\mathrm{b}$ & 1 & 0 & 0 \\
\hline & & & & $\mathrm{b}$ & 2 & 0 & 0 \\
\hline & & & & $\mathrm{C}$ & 1 & 0 & 2 \\
\hline & & & & $\mathrm{C}$ & 2 & 0 & 0 \\
\hline & & & & $d$ & 1 & 0 & 0 \\
\hline & & & & $d$ & 2 & 0 & 0 \\
\hline \multirow[t]{8}{*}{221} & Block 3 & $A$ & 6 & $\mathrm{a}$ & 1 & 604 & 28 \\
\hline & & & & $\mathrm{a}$ & 2 & 720 & 11 \\
\hline & & & & $b$ & 1 & 207 & 18 \\
\hline & & & & $b$ & 2 & 117 & 21 \\
\hline & & & & $\mathrm{C}$ & 1 & 599 & 87 \\
\hline & & & & $\mathrm{C}$ & 2 & 142 & 51 \\
\hline & & & & $d$ & 1 & 608 & 36 \\
\hline & & & & $d$ & 2 & 439 & 8 \\
\hline \multirow[t]{8}{*}{221} & Block 3 & $A$ & 7 & $a$ & 1 & 0 & \\
\hline & & & no Myc & $a$ & 2 & 0 & \\
\hline & & & & $b$ & 1 & 0 & \\
\hline & & & & $b$ & 2 & 0 & \\
\hline & & & & $C$ & 1 & 0 & \\
\hline & & & & $\mathrm{C}$ & 2 & 0 & \\
\hline & & & & $d$ & 1 & 0 & \\
\hline & & & & $d$ & 2 & 0 & \\
\hline \multirow[t]{8}{*}{221} & Block 3 & $A$ & 8 & $a$ & 1 & 67 & 405 \\
\hline & & & no Myc & $a$ & 2 & 4 & 30 \\
\hline & & & & $b$ & 1 & 24 & 268 \\
\hline & & & & $b$ & 2 & 1 & 61 \\
\hline & & & & $\mathrm{C}$ & 1 & 59 & 92 \\
\hline & & & & $\mathrm{C}$ & 2 & 32 & 90 \\
\hline & & & & $d$ & 1 & 16 & 226 \\
\hline & & & & $d$ & 2 & 19 & 67 \\
\hline \multirow[t]{6}{*}{223} & Block 1 & $B$ & 1 & $a$ & 1 & 0 & 0 \\
\hline & & & & $\mathrm{a}$ & 2 & 0 & 0 \\
\hline & & & & $\mathrm{b}$ & 1 & 0 & 1 \\
\hline & & & & $b$ & 2 & 0 & 0 \\
\hline & & & & C & 1 & 0 & 0 \\
\hline & & & & C & 2 & 0 & 0 \\
\hline
\end{tabular}




\begin{tabular}{|c|c|c|c|c|c|c|c|}
\hline & & & & $d$ & 1 & 0 & 0 \\
\hline & & & & $d$ & 2 & 0 & 0 \\
\hline \multirow[t]{8}{*}{223} & Block 1 & $B$ & 2 & $a$ & 1 & & \\
\hline & & & & $a$ & 2 & & \\
\hline & & & & $b$ & 1 & & \\
\hline & & & & $b$ & 2 & & \\
\hline & & & & $\mathrm{C}$ & 1 & & \\
\hline & & & & $\mathrm{C}$ & 2 & & \\
\hline & & & & $d$ & 1 & & \\
\hline & & & & $d$ & 2 & & \\
\hline \multirow[t]{8}{*}{223} & Block 1 & $B$ & 3 & $a$ & 1 & 23 & 16 \\
\hline & & & & $a$ & 2 & 9 & 16 \\
\hline & & & & $b$ & 1 & 7 & 236 \\
\hline & & & & $b$ & 2 & 0 & 203 \\
\hline & & & & $\mathrm{C}$ & 1 & 23 & 141 \\
\hline & & & & $\mathrm{C}$ & 2 & 5 & 216 \\
\hline & & & & $d$ & 1 & 5 & 128 \\
\hline & & & & $d$ & 2 & 1 & 202 \\
\hline \multirow[t]{8}{*}{223} & Block 1 & $B$ & 4 & $a$ & 1 & 0 & 39 \\
\hline & & & & $a$ & 2 & 0 & 55 \\
\hline & & & & $\mathrm{b}$ & 1 & 0 & 0 \\
\hline & & & & $b$ & 2 & 0 & 0 \\
\hline & & & & $\mathrm{C}$ & 1 & 0 & 0 \\
\hline & & & & $c$ & 2 & 0 & 0 \\
\hline & & & & $\mathrm{d}$ & 1 & 0 & 222 \\
\hline & & & & $d$ & 2 & 0 & 335 \\
\hline \multirow[t]{8}{*}{223} & Block 1 & $B$ & 5 & $a$ & 1 & 207 & 176 \\
\hline & & & & $a$ & 2 & 127 & 57 \\
\hline & & & & $b$ & 1 & 77 & 252 \\
\hline & & & & $\mathrm{b}$ & 2 & 18 & 64 \\
\hline & & & & $\mathrm{C}$ & 1 & 80 & 169 \\
\hline & & & & $\mathrm{C}$ & 2 & 17 & 149 \\
\hline & & & & $d$ & 1 & 202 & 228 \\
\hline & & & & $d$ & 2 & 70 & 258 \\
\hline \multirow[t]{7}{*}{223} & Block 1 & $B$ & 6 & $a$ & 1 & 0 & \\
\hline & & & & $a$ & 2 & 0 & \\
\hline & & & & $b$ & 1 & 0 & \\
\hline & & & & $\mathrm{b}$ & 2 & 0 & \\
\hline & & & & 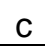 & 1 & 0 & \\
\hline & & & & $C$ & 2 & 0 & \\
\hline & & & & $d$ & 1 & 0 & \\
\hline
\end{tabular}




\begin{tabular}{|c|c|c|c|c|c|c|c|}
\hline & & & & $d$ & 2 & 0 & \\
\hline \multirow[t]{8}{*}{223} & Block 1 & $B$ & 7 & $a$ & 1 & 107 & 45 \\
\hline & & & & $a$ & 2 & 124 & 133 \\
\hline & & & & $b$ & 1 & 89 & 73 \\
\hline & & & & $b$ & 2 & 37 & 19 \\
\hline & & & & C & 1 & 78 & 79 \\
\hline & & & & $\mathrm{C}$ & 2 & 137 & 36 \\
\hline & & & & $d$ & 1 & 84 & 44 \\
\hline & & & & $d$ & 2 & 33 & 109 \\
\hline \multirow[t]{8}{*}{223} & Block 1 & $B$ & 8 & $a$ & 1 & 415 & 86 \\
\hline & & & & $a$ & 2 & 1205 & 438 \\
\hline & & & & $b$ & 1 & 134 & 53 \\
\hline & & & & $b$ & 2 & 277 & 35 \\
\hline & & & & $\mathrm{C}$ & 1 & 101 & 32 \\
\hline & & & & $\mathrm{C}$ & 2 & 71 & 13 \\
\hline & & & & $d$ & 1 & 462 & 89 \\
\hline & & & & $d$ & 2 & 255 & 86 \\
\hline \multirow[t]{8}{*}{225} & Block 2 & $\mathrm{~B}$ & 1 & $\mathrm{a}$ & 1 & 773 & 75 \\
\hline & & & & $a$ & 2 & 371 & 7 \\
\hline & & & & $b$ & 1 & 369 & 23 \\
\hline & & & & $\mathrm{b}$ & 2 & 43 & 0 \\
\hline & & & & $\mathrm{C}$ & 1 & 413 & 64 \\
\hline & & & & $\mathrm{C}$ & 2 & 58 & 31 \\
\hline & & & & $d$ & 1 & 655 & 120 \\
\hline & & & & $d$ & 2 & 316 & 101 \\
\hline \multirow[t]{8}{*}{225} & Block 2 & $\mathrm{~B}$ & 2 & $a$ & 1 & 4 & 22 \\
\hline & & & & $a$ & 2 & 9 & 3 \\
\hline & & & & $b$ & 1 & 0 & 15 \\
\hline & & & & $\mathrm{b}$ & 2 & 3 & 58 \\
\hline & & & & $\mathrm{C}$ & 1 & 8 & 47 \\
\hline & & & & $\mathrm{C}$ & 2 & 12 & 47 \\
\hline & & & & $d$ & 1 & 10 & 35 \\
\hline & & & & $d$ & 2 & 17 & 43 \\
\hline \multirow[t]{8}{*}{225} & Block 2 & $\mathrm{~B}$ & 3 & $a$ & 1 & 278 & 17 \\
\hline & & & & $a$ & 2 & 92 & 18 \\
\hline & & & & $b$ & 1 & 298 & 19 \\
\hline & & & & $\mathrm{b}$ & 2 & 144 & 1 \\
\hline & & & & $C$ & 1 & 101 & 0 \\
\hline & & & & C & 2 & 131 & 0 \\
\hline & & & & $d$ & 1 & 42 & 0 \\
\hline & & & & $\mathrm{d}$ & 2 & 15 & 0 \\
\hline
\end{tabular}




\begin{tabular}{|c|c|c|c|c|c|c|c|}
\hline \multirow[t]{8}{*}{225} & Block 2 & $\mathrm{~B}$ & 4 & $\mathrm{a}$ & 1 & & \\
\hline & & & & $\mathrm{a}$ & 2 & & \\
\hline & & & & $b$ & 1 & & \\
\hline & & & & $b$ & 2 & & \\
\hline & & & & $\mathrm{C}$ & 1 & & \\
\hline & & & & C & 2 & & \\
\hline & & & & $d$ & 1 & & \\
\hline & & & & $d$ & 2 & & \\
\hline \multirow[t]{8}{*}{225} & Block 2 & $\mathrm{~B}$ & 5 & $\mathrm{a}$ & 1 & 0 & 464 \\
\hline & & & & $\mathrm{a}$ & 2 & 0 & 130 \\
\hline & & & & $b$ & 1 & 0 & 66 \\
\hline & & & & $b$ & 2 & 0 & 0 \\
\hline & & & & $\mathrm{C}$ & 1 & 0 & 84 \\
\hline & & & & $\mathrm{C}$ & 2 & 0 & 0 \\
\hline & & & & $d$ & 1 & 0 & 407 \\
\hline & & & & $d$ & 2 & 0 & 68 \\
\hline \multirow[t]{8}{*}{225} & Block 2 & $\mathrm{~B}$ & 6 & $\mathrm{a}$ & 1 & 0 & 11 \\
\hline & & & & $a$ & 2 & 0 & 21 \\
\hline & & & & $b$ & 1 & 0 & 18 \\
\hline & & & & $b$ & 2 & 0 & 2 \\
\hline & & & & $\mathrm{C}$ & 1 & 0 & 0 \\
\hline & & & & $\mathrm{C}$ & 2 & 0 & 0 \\
\hline & & & & $d$ & 1 & 0 & 5 \\
\hline & & & & $\mathrm{d}$ & 2 & 0 & 2 \\
\hline \multirow[t]{8}{*}{225} & Block 2 & $\mathrm{~B}$ & 7 & $\mathrm{a}$ & 1 & 107 & 31 \\
\hline & & & & $\mathrm{a}$ & 2 & 7 & 20 \\
\hline & & & & $b$ & 1 & 251 & 0 \\
\hline & & & & $b$ & 2 & 256 & 0 \\
\hline & & & & $\mathrm{C}$ & 1 & 21 & 43 \\
\hline & & & & $C$ & 2 & 0 & 21 \\
\hline & & & & $d$ & 1 & 18 & 30 \\
\hline & & & & $d$ & 2 & 0 & 9 \\
\hline \multirow[t]{8}{*}{225} & Block 2 & $\mathrm{~B}$ & 8 & $\mathrm{a}$ & 1 & 251 & 36 \\
\hline & & & & $a$ & 2 & 279 & 53 \\
\hline & & & & b & 1 & 145 & 47 \\
\hline & & & & $b$ & 2 & 130 & 66 \\
\hline & & & & $\mathrm{C}$ & 1 & 41 & 23 \\
\hline & & & & $\mathrm{C}$ & 2 & 49 & 42 \\
\hline & & & & $d$ & 1 & 65 & 40 \\
\hline & & & & $d$ & 2 & 22 & 32 \\
\hline 227 & Block 3 & B & 1 & $\mathrm{a}$ & 1 & 0 & 65 \\
\hline
\end{tabular}




\begin{tabular}{|c|c|c|c|c|c|c|c|}
\hline & & & & $a$ & 2 & 0 & 11 \\
\hline & & & & $b$ & 1 & 0 & 0 \\
\hline & & & & $b$ & 2 & 0 & 0 \\
\hline & & & & C & 1 & 0 & 115 \\
\hline & & & & C & 2 & 0 & 39 \\
\hline & & & & $\mathrm{d}$ & 1 & 0 & 351 \\
\hline & & & & $d$ & 2 & 0 & 258 \\
\hline \multirow[t]{8}{*}{227} & Block 3 & $B$ & 2 & $a$ & 1 & 0 & 17 \\
\hline & & & & $a$ & 2 & 0 & 2 \\
\hline & & & & $b$ & 1 & 0 & 6 \\
\hline & & & & $b$ & 2 & 0 & 0 \\
\hline & & & & $\mathrm{C}$ & 1 & 0 & 6 \\
\hline & & & & $c$ & 2 & 0 & 7 \\
\hline & & & & $d$ & 1 & 0 & 14 \\
\hline & & & & $d$ & 2 & 0 & 10 \\
\hline \multirow[t]{8}{*}{227} & Block 3 & $\mathrm{~B}$ & 3 & $a$ & 1 & 0 & 1 \\
\hline & & & & $a$ & 2 & 0 & 2 \\
\hline & & & & $b$ & 1 & 0 & 1 \\
\hline & & & & $b$ & 2 & 0 & 0 \\
\hline & & & & C & 1 & 0 & 0 \\
\hline & & & & C & 2 & 0 & 0 \\
\hline & & & & $d$ & 1 & 0 & 0 \\
\hline & & & & $d$ & 2 & 0 & 0 \\
\hline \multirow[t]{8}{*}{227} & Block 3 & $B$ & 4 & $a$ & 1 & 217 & 0 \\
\hline & & & & $\mathrm{a}$ & 2 & 94 & 0 \\
\hline & & & & $b$ & 1 & 2 & 0 \\
\hline & & & & $b$ & 2 & 0 & 0 \\
\hline & & & & C & 1 & 15 & 0 \\
\hline & & & & C & 2 & 0 & 0 \\
\hline & & & & $d$ & 1 & 347 & 0 \\
\hline & & & & $d$ & 2 & 156 & 0 \\
\hline \multirow[t]{8}{*}{227} & Block 3 & $B$ & 5 & $a$ & 1 & 369 & 0 \\
\hline & & & & $a$ & 2 & 778 & 0 \\
\hline & & & & $b$ & 1 & 246 & 0 \\
\hline & & & & $\mathrm{b}$ & 2 & 418 & 0 \\
\hline & & & & C & 1 & 43 & 0 \\
\hline & & & & C & 2 & 11 & 0 \\
\hline & & & & $d$ & 1 & 269 & 0 \\
\hline & & & & $d$ & 2 & 263 & 0 \\
\hline \multirow[t]{2}{*}{227} & Block 3 & $B$ & 6 & $a$ & 1 & & 0 \\
\hline & & & & $a$ & 2 & & 0 \\
\hline
\end{tabular}




\begin{tabular}{|c|c|c|c|c|c|c|c|}
\hline & & & & $b$ & 1 & & 0 \\
\hline & & & & $b$ & 2 & & 0 \\
\hline & & & & $c$ & 1 & & 0 \\
\hline & & & & c & 2 & & 0 \\
\hline & & & & d & 1 & & 0 \\
\hline & & & & d & 2 & & 0 \\
\hline \multirow[t]{8}{*}{227} & Block 3 & B & 7 & $a$ & 1 & & 0 \\
\hline & & & & $a$ & 2 & & \\
\hline & & & & $\mathrm{b}$ & 1 & & \\
\hline & & & & $\mathrm{b}$ & 2 & & \\
\hline & & & & C & 1 & & \\
\hline & & & & C & 2 & & \\
\hline & & & & d & 1 & & \\
\hline & & & & d & 2 & & \\
\hline \multirow[t]{8}{*}{227} & Block 3 & $B$ & 8 & $a$ & 1 & 391 & 110 \\
\hline & & & & a & 2 & 52 & 52 \\
\hline & & & & $b$ & 1 & 112 & 47 \\
\hline & & & & $b$ & 2 & 6 & 12 \\
\hline & & & & C & 1 & 173 & 52 \\
\hline & & & & C & 2 & 36 & 67 \\
\hline & & & & d & 1 & 382 & 67 \\
\hline & & & & $d$ & 2 & 200 & 43 \\
\hline
\end{tabular}

B. Conteo de esporas en el segundo muestreo (T1)

\begin{tabular}{|c|c|c|c|c|c|c|c|c|c|c|c|c|c|c|c|c|c|}
\hline Taq & Les. & \multicolumn{10}{|c|}{ 6días } \\
\hline $\mathbf{1}$ & 1 & 76 & 143 & 7 & 2 & 138 & 91 & 125 & 130 & 1 & 3 & 2 & 0 & 1 & 0 & 0 & 1 \\
\hline & 2 & 24 & 15 & 18 & 2 & 8 & 1 & 2 & 3 & 0 & 0 & 0 & 0 & 0 & 0 & 2 & 0 \\
\hline & 3 & 76 & 88 & 5 & 1 & 68 & 110 & 61 & 143 & 70 & 119 & 9 & 0 & 9 & 11 & 38 & 15 \\
\hline & 4 & 0 & 0 & 0 & 0 & 0 & 0 & 0 & 0 & 19 & 1 & 3 & 1 & 8 & 0 & 6 & 10 \\
\hline & 5 & 50 & 32 & 28 & 0 & 2 & 0 & 4 & 0 & 20 & 29 & 1 & 0 & 7 & 25 & 4 & 4 \\
\hline & 6 & 166 & 164 & 402 & 328 & 443 & 279 & 318 & 147 & 6 & 7 & 6 & 4 & 2 & 1 & 14 & 29 \\
\hline & 7 & 0 & 0 & 0 & 0 & 10 & 8 & 1 & 2 & 116 & 334 & 184 & 4 & 21 & 59 & 1 & 35 \\
\hline & 8 & 0 & 0 & 0 & 0 & 0 & 0 & 0 & 0 & 0 & 0 & 0 & 0 & 0 & 0 & 0 & 0 \\
\hline $\mathbf{5}$ & 1 & 0 & 0 & 0 & 0 & 0 & 0 & 0 & 0 & 0 & 0 & 0 & 0 & 70 & 1 & 11 & 0 \\
\hline & 2 & 0 & 0 & 0 & 0 & 0 & 0 & 1 & 11 & 8 & 4 & 0 & 0 & 0 & 7 & 0 & 0 \\
\hline & 3 & 7 & 1 & 0 & 0 & 6 & 7 & 14 & 2 & 4 & 0 & 2 & 0 & 0 & 0 & 0 & 0 \\
\hline & 4 & 0 & 0 & 0 & 0 & 0 & 0 & 0 & 0 & 0 & 0 & 0 & 0 & 0 & 0 & 0 & 0 \\
\hline & 5 & 0 & 0 & 0 & 0 & 0 & 0 & 0 & 0 & 0 & 0 & 0 & 0 & 0 & 0 & 0 & 0 \\
\hline
\end{tabular}




\begin{tabular}{|c|c|c|c|c|c|c|c|c|c|c|c|c|c|c|c|c|c|}
\hline & 6 & 0 & 0 & 0 & 0 & 0 & 0 & 0 & 0 & 0 & 0 & 0 & 0 & 2 & 0 & 1 & 0 \\
\hline & 7 & 0 & 0 & 0 & 0 & 0 & 0 & 0 & 0 & 0 & 0 & 0 & 0 & 0 & 2 & 0 & 0 \\
\hline & 8 & 0 & 0 & 0 & 0 & 0 & 0 & 0 & 0 & 0 & 0 & 0 & 0 & 0 & 0 & 0 & 0 \\
\hline \multirow[t]{8}{*}{9} & 1 & 0 & 0 & 0 & 0 & 0 & 0 & 0 & 0 & 0 & 0 & 0 & 0 & 0 & 0 & 0 & 0 \\
\hline & 2 & 0 & 0 & 0 & 0 & 0 & 0 & 0 & 0 & 0 & 0 & 0 & 0 & 0 & 0 & 0 & 0 \\
\hline & 3 & 0 & 0 & 0 & 0 & 0 & 0 & 0 & 0 & 0 & 0 & 0 & 0 & 0 & 0 & 0 & 0 \\
\hline & 4 & 0 & 0 & 0 & 0 & 0 & 0 & 0 & 0 & 0 & 0 & 0 & 0 & 0 & 0 & 0 & 0 \\
\hline & 5 & 0 & 0 & 0 & 0 & 0 & 0 & 0 & 0 & 0 & 0 & 0 & 0 & 0 & 0 & 0 & 0 \\
\hline & 6 & 0 & 0 & 0 & 0 & 0 & 0 & 0 & 0 & 0 & 0 & 0 & 0 & 0 & 0 & 0 & 0 \\
\hline & 7 & 0 & 0 & 0 & 0 & 0 & 0 & 0 & 0 & 75 & 8 & 11 & 4 & 16 & 7 & 106 & 34 \\
\hline & 8 & 0 & 0 & 0 & 0 & 0 & 0 & 0 & 0 & 0 & 0 & 0 & 0 & 0 & 0 & 0 & 0 \\
\hline \multirow[t]{8}{*}{13} & 1 & 0 & 0 & 0 & 0 & 0 & 0 & 0 & 0 & 1 & 1 & 3 & 0 & 1 & 5 & 0 & 3 \\
\hline & 2 & 739 & 203 & 571 & 397 & 524 & 318 & 415 & 88 & 68 & 69 & 85 & 75 & 98 & 46 & 47 & 40 \\
\hline & 3 & 20 & 184 & 180 & 500 & 32 & \begin{tabular}{|l|}
39 \\
\end{tabular} & 91 & 111 & 98 & 359 & 11 & 17 & 6 & 112 & 37 & 25 \\
\hline & 4 & 0 & 0 & 0 & 0 & 0 & 0 & 0 & 0 & 137 & 272 & 0 & 0 & 0 & 0 & 277 & 389 \\
\hline & 5 & 546 & 536 & 3 & 0 & 71 & 6 & 346 & 580 & 0 & 0 & 0 & 0 & 0 & 0 & 0 & 0 \\
\hline & 6 & 59 & 17 & 118 & 131 & 11 & 0 & 40 & 4 & 2 & 11 & 16 & 270 & 0 & 0 & 0 & 0 \\
\hline & 7 & 125 & 241 & 0 & 0 & 311 & 106 & 222 & 373 & 40 & 89 & 12 & 203 & 6 & 0 & 6 & 0 \\
\hline & 8 & 9 & 60 & 0 & \begin{tabular}{|l|}
67 \\
\end{tabular} & 0 & 0 & 35 & 0 & 2 & 9 & 1 & 0 & 0 & 0 & 3 & 6 \\
\hline \multirow[t]{8}{*}{17} & 1 & 46 & 14 & 6 & 0 & 7 & 0 & 7 & 0 & 0 & 0 & 0 & 0 & 0 & 0 & 0 & 0 \\
\hline & 2 & 78 & 99 & 438 & 137 & 20 & 16 & 82 & 45 & 0 & 0 & 0 & 0 & 0 & 0 & 0 & 0 \\
\hline & 3 & 0 & 0 & 0 & 0 & 0 & 0 & 0 & 0 & 0 & 0 & 0 & 0 & 0 & 0 & 0 & 0 \\
\hline & 4 & 6 & 8 & 33 & 7 & 26 & 44 & 12 & 9 & 0 & 0 & 0 & 0 & 0 & 0 & 0 & 0 \\
\hline & 5 & 68 & 8 & 88 & 69 & 33 & 7 & 38 & 1 & 0 & 0 & 0 & 0 & 0 & 0 & 0 & 0 \\
\hline & 6 & 50 & 34 & 33 & 2 & 24 & 47 & 31 & 63 & 0 & 0 & 0 & 0 & 0 & 0 & 0 & 0 \\
\hline & 7 & 95 & 239 & 214 & 22 & 192 & 42 & 349 & 49 & 0 & 0 & 1 & 0 & 15 & 5 & 11 & 13 \\
\hline & 8 & 112 & 0 & 104 & 34 & 303 & 235 & 13 & 2 & 0 & 3 & 0 & 1 & 2 & 0 & 1 & 3 \\
\hline \multirow[t]{8}{*}{21} & 1 & 0 & 0 & 0 & 0 & 0 & 0 & 0 & 0 & 0 & 0 & 0 & 0 & 0 & 0 & 0 & 0 \\
\hline & 2 & 0 & 0 & 0 & 0 & 0 & 0 & 0 & 0 & 0 & 0 & 0 & 0 & 0 & 0 & 1 & 1 \\
\hline & 3 & 0 & 0 & 0 & 0 & 0 & 0 & 0 & 0 & 0 & 0 & 2 & 0 & 0 & 0 & 0 & 0 \\
\hline & 4 & 0 & 0 & 6 & 0 & 13 & 4 & 1 & 0 & 0 & 0 & 0 & 0 & 0 & 0 & 0 & 0 \\
\hline & 5 & 0 & 0 & 56 & 1 & 2 & 0 & 2 & 2 & & & & & & & & \\
\hline & 6 & 8 & 2 & 7 & 17 & 19 & 3 & 5 & 17 & & & & & & & & \\
\hline & 7 & 0 & 0 & 7 & 1 & 25 & 2 & 0 & 0 & & & & & & & & \\
\hline & 8 & 7 & 4 & 6 & 1 & 3 & 0 & 29 & 65 & & & & & & & & \\
\hline \multirow[t]{2}{*}{25} & 1 & 3 & 1 & 11 & 2 & 16 & 0 & 4 & 7 & 0 & 0 & 0 & 0 & 0 & 2 & 0 & 0 \\
\hline & 2 & 0 & 0 & 0 & 0 & 0 & 0 & 0 & 0 & 0 & 0 & 0 & 0 & 0 & 6 & 0 & 0 \\
\hline \multirow[t]{2}{*}{26} & 1 & 5 & 0 & 5 & 1 & 10 & 3 & 0 & 15 & 0 & 0 & 0 & 0 & 0 & 0 & 0 & 0 \\
\hline & 2 & 0 & 0 & 0 & 0 & 0 & 0 & 0 & 0 & 1 & 0 & 1 & 0 & 1 & 1 & 0 & 0 \\
\hline \multirow[t]{2}{*}{27} & 1 & 0 & 0 & 0 & 0 & 0 & 0 & 0 & 0 & 101 & 14 & 0 & 0 & 24 & 77 & 14 & 75 \\
\hline & 2 & 0 & 0 & 0 & 0 & 0 & 0 & 0 & 0 & 0 & 0 & 0 & 0 & 0 & 0 & 0 & 0 \\
\hline 37 & 1 & 84 & 116 & 309 & 172 & 40 & 77 & 16 & 4 & 0 & 0 & 0 & 0 & 0 & 2 & 0 & 0 \\
\hline
\end{tabular}




\begin{tabular}{|c|c|c|c|c|c|c|c|c|c|c|c|c|c|c|c|c|c|}
\hline & 2 & 0 & 0 & 0 & 0 & 0 & 0 & 0 & 0 & 0 & 0 & 0 & 0 & 0 & 0 & 0 & 0 \\
\hline & 3 & 0 & 0 & 12 & 5 & 0 & 15 & 0 & 0 & 7 & 0 & 6 & 16 & 3 & 0 & 1 & 2 \\
\hline & 4 & 0 & 0 & 0 & 0 & 0 & 0 & \begin{tabular}{|l|}
19 \\
\end{tabular} & 9 & 0 & 1 & 1 & 1 & 0 & 0 & 0 & 0 \\
\hline & 5 & 5 & 7 & 0 & 0 & \begin{tabular}{|l|}
13 \\
\end{tabular} & 8 & \begin{tabular}{|l|}
43 \\
\end{tabular} & 7 & 0 & 0 & 0 & 0 & 0 & 0 & 0 & 0 \\
\hline & 6 & 0 & 19 & 12 & 22 & 1 & 2 & 0 & 0 & 0 & 0 & 0 & 0 & 0 & 0 & 0 & 0 \\
\hline & 7 & 0 & 0 & 0 & 0 & 0 & 0 & 0 & 0 & 0 & 0 & 0 & 0 & 0 & 0 & 0 & 0 \\
\hline & 8 & 154 & 0 & 307 & 98 & 55 & 22 & \begin{tabular}{|l|}
28 \\
\end{tabular} & \begin{tabular}{|l|}
32 \\
\end{tabular} & 0 & 0 & 0 & 0 & 0 & 0 & 0 & 0 \\
\hline \multirow[t]{8}{*}{41} & 1 & 0 & 0 & 0 & 3 & 6 & 3 & 0 & 0 & 0 & 0 & 0 & 0 & 0 & 0 & 0 & 0 \\
\hline & 2 & 0 & 0 & 0 & 0 & 0 & 0 & 0 & 0 & 0 & 0 & 0 & 0 & 0 & 0 & 0 & 0 \\
\hline & 3 & 12 & 1 & 0 & 0 & 1 & 0 & \begin{tabular}{|l|}
22 \\
\end{tabular} & 0 & 0 & 0 & 3 & 12 & 0 & 0 & 1 & 0 \\
\hline & 4 & 35 & 8 & 1 & 0 & 74 & 34 & \begin{tabular}{|l|}
54 \\
\end{tabular} & 7 & 17 & 0 & 31 & 7 & 2 & 4 & 0 & 0 \\
\hline & 5 & 85 & 21 & 5 & 2 & 0 & 0 & 0 & 0 & 3 & 0 & 15 & 1 & 3 & 0 & 5 & 4 \\
\hline & 6 & 33 & 27 & 1 & 0 & \begin{tabular}{|l|}
14 \\
\end{tabular} & 0 & 8 & 4 & 0 & 0 & 0 & 0 & 0 & 0 & 0 & 0 \\
\hline & 7 & 0 & 0 & 0 & 0 & 0 & 0 & 0 & 0 & 0 & 0 & 0 & 0 & 0 & 0 & 0 & 0 \\
\hline & 8 & 0 & 0 & 0 & 0 & 0 & 0 & 0 & 0 & 0 & 0 & 0 & 0 & 0 & 0 & 0 & 0 \\
\hline \multirow[t]{8}{*}{45} & 1 & 84 & 100 & 21 & 226 & 1 & 0 & 130 & 266 & 1 & 9 & 0 & 8 & 22 & 30 & 0 & 0 \\
\hline & 2 & 0 & 0 & 0 & 0 & 0 & 0 & 0 & 0 & 0 & 0 & 0 & 0 & 4 & 0 & 0 & 0 \\
\hline & 3 & 0 & 0 & 0 & 0 & 0 & 0 & 0 & 0 & 9 & 6 & 3 & 0 & 0 & 0 & 11 & 5 \\
\hline & 4 & 0 & 0 & 0 & 0 & 0 & 0 & 0 & 0 & 0 & 0 & 0 & 0 & 0 & 0 & 0 & 0 \\
\hline & 5 & 0 & 0 & 0 & 0 & 0 & 0 & 0 & 0 & 14 & 0 & 7 & 16 & 1 & 0 & 12 & 0 \\
\hline & 6 & 0 & 0 & 0 & 0 & 0 & 0 & 0 & 0 & 0 & 0 & 0 & 0 & 0 & 0 & 0 & 0 \\
\hline & 7 & 0 & 0 & 0 & 0 & 0 & 0 & 0 & 0 & 26 & 1 & 7 & 0 & 6 & 9 & 1 & 11 \\
\hline & 8 & 0 & 0 & 0 & 0 & 0 & 0 & 0 & 0 & 1 & 3 & 1 & 1 & 1 & 4 & 7 & 1 \\
\hline \multirow[t]{8}{*}{49} & 1 & 0 & 0 & 0 & 0 & 0 & 0 & 0 & 0 & 121 & 15 & 64 & 94 & 8 & 8 & 211 & 289 \\
\hline & 2 & 8 & 1 & 50 & 70 & \begin{tabular}{|l|}
37 \\
\end{tabular} & 13 & 0 & 1 & 0 & 0 & 0 & 0 & 0 & 0 & 0 & 0 \\
\hline & 3 & 37 & 33 & 43 & 0 & 2 & 0 & 0 & 0 & 4 & 24 & 0 & 12 & 5 & 1 & 3 & 63 \\
\hline & 4 & 0 & 0 & 0 & 0 & 0 & 0 & 0 & 0 & 2 & 2 & 11 & 1 & 2 & 0 & 0 & 0 \\
\hline & 5 & 0 & 0 & 8 & 0 & 15 & 47 & 0 & 1 & 0 & 0 & 0 & 0 & 0 & 0 & 0 & 0 \\
\hline & 6 & 23 & 33 & 103 & 72 & 20 & 43 & \begin{tabular}{|l|}
52 \\
\end{tabular} & \begin{tabular}{|l|}
23 \\
\end{tabular} & 0 & 1 & 1 & 0 & 0 & 1 & 0 & 0 \\
\hline & 7 & 124 & 13 & 73 & 0 & \begin{tabular}{|l|}
48 \\
\end{tabular} & 21 & 0 & \begin{tabular}{|l|}
28 \\
\end{tabular} & 1 & 3 & 13 & 44 & 37 & \begin{tabular}{|l|}
54 \\
\end{tabular} & 9 & \begin{tabular}{|l|}
12 \\
\end{tabular} \\
\hline & 8 & 0 & 0 & 0 & 0 & 0 & 0 & 0 & 0 & 0 & 0 & 0 & 0 & 0 & 0 & 0 & 0 \\
\hline \multirow[t]{8}{*}{53} & 1 & 190 & 137 & 4 & 0 & 64 & 153 & 416 & 133 & 75 & 95 & 68 & 17 & 0 & 17 & 1 & 0 \\
\hline & 2 & 15 & 3 & 36 & 7 & 43 & 8 & \begin{tabular}{|l|}
56 \\
\end{tabular} & \begin{tabular}{|l|}
53 \\
\end{tabular} & 85 & 3 & 173 & 71 & 117 & \begin{tabular}{|l|}
78 \\
\end{tabular} & 25 & 9 \\
\hline & 3 & 0 & 0 & 0 & 0 & 8 & 5 & 1 & \begin{tabular}{|l|}
13 \\
\end{tabular} & 0 & 5 & 0 & 0 & 2 & 0 & 0 & 5 \\
\hline & 4 & 0 & 0 & 0 & 0 & 1 & 5 & 2 & 0 & 0 & 0 & 0 & 0 & 0 & 0 & 0 & 5 \\
\hline & 5 & 40 & 182 & 91 & 110 & 176 & 213 & \begin{tabular}{|l|}
38 \\
\end{tabular} & 5 & 38 & 43 & 2 & 21 & 263 & 354 & 198 & 226 \\
\hline & 6 & 196 & 147 & 271 & 377 & 88 & 36 & \begin{tabular}{|l|}
137 \\
\end{tabular} & \begin{tabular}{|l|}
76 \\
\end{tabular} & 3 & 0 & 2 & 3 & 11 & \begin{tabular}{|l|}
11 \\
\end{tabular} & 8 & 13 \\
\hline & 7 & 0 & 0 & 14 & 5 & 38 & 0 & 0 & 0 & 49 & 73 & 1 & 0 & 374 & 430 & 179 & 295 \\
\hline & 8 & 47 & 80 & 0 & 0 & \begin{tabular}{|l|}
97 \\
\end{tabular} & 77 & 9 & \begin{tabular}{|l|}
16 \\
\end{tabular} & 0 & 2 & 0 & 0 & 0 & 0 & 0 & 0 \\
\hline \multirow[t]{3}{*}{57} & 1 & 0 & 0 & 0 & 0 & 0 & 0 & 0 & 0 & 0 & 0 & 0 & 0 & 0 & 0 & 0 & 0 \\
\hline & 2 & 0 & 0 & 0 & 0 & 0 & 0 & 0 & 0 & 5 & 2 & 4 & 7 & 9 & \begin{tabular}{|l|}
11 \\
\end{tabular} & 5 & 11 \\
\hline & 3 & 58 & 123 & 31 & 3 & 30 & 0 & \begin{tabular}{|l|}
62 \\
\end{tabular} & \begin{tabular}{|l|}
39 \\
\end{tabular} & 20 & 10 & 6 & 6 & 25 & \begin{tabular}{|l|}
52 \\
\end{tabular} & 25 & \begin{tabular}{|l|}
14 \\
\end{tabular} \\
\hline
\end{tabular}




\begin{tabular}{|c|c|c|c|c|c|c|c|c|c|c|c|c|c|c|c|c|c|}
\hline & 4 & 102 & 303 & 362 & 626 & 170 & 272 & \begin{tabular}{|l|}
157 \\
\end{tabular} & 0 & 33 & 4 & 13 & 3 & 14 & 9 & 14 & 2 \\
\hline & 5 & 35 & 34 & \begin{tabular}{|l|}
60 \\
\end{tabular} & 52 & 51 & 82 & \begin{tabular}{|l|}
34 \\
\end{tabular} & \begin{tabular}{|l|}
48 \\
\end{tabular} & 39 & 30 & 45 & 62 & 2 & 11 & 12 & 36 \\
\hline & 6 & 0 & 0 & 0 & 0 & 0 & 0 & 0 & 0 & 0 & 0 & 0 & 0 & 0 & 0 & 0 & 0 \\
\hline & 7 & 215 & 243 & 506 & 166 & \begin{tabular}{|l|}
247 \\
\end{tabular} & 301 & \begin{tabular}{|l|}
41 \\
\end{tabular} & \begin{tabular}{|l|}
39 \\
\end{tabular} & 23 & 29 & 0 & 0 & 18 & 6 & 19 & 15 \\
\hline & 8 & 268 & 8 & 260 & \begin{tabular}{|l|}
14 \\
\end{tabular} & 168 & 73 & 210 & \begin{tabular}{|l|}
77 \\
\end{tabular} & 0 & 0 & 0 & 0 & 0 & 0 & 0 & 0 \\
\hline \multirow[t]{2}{*}{61} & 1 & 0 & 0 & 0 & 0 & 0 & 0 & 0 & 0 & 58 & 2 & 7 & 1 & 3 & 0 & 52 & 16 \\
\hline & 2 & 46 & 5 & 17 & 12 & 3 & 0 & 18 & 37 & 4 & 12 & 4 & 27 & 0 & 5 & 0 & 1 \\
\hline \multirow[t]{2}{*}{62} & 1 & 0 & 0 & 0 & 0 & 1 & 1 & 0 & 0 & 0 & 0 & 0 & 0 & 0 & 0 & 0 & 0 \\
\hline & 2 & 0 & 0 & 0 & 0 & 0 & 0 & 0 & 0 & 0 & 0 & 0 & 0 & 0 & 0 & 0 & 0 \\
\hline \multirow[t]{2}{*}{63} & 1 & 0 & 0 & 0 & 0 & 0 & 0 & 0 & 0 & 0 & 0 & 0 & 0 & 0 & 0 & 0 & 0 \\
\hline & 2 & 0 & 0 & 0 & 0 & 0 & 0 & 0 & 0 & 11 & 13 & 2 & 0 & 10 & 1 & 18 & 13 \\
\hline \multirow[t]{8}{*}{73} & 1 & 0 & 0 & 0 & 0 & 0 & 0 & 0 & 0 & 77 & 0 & 4 & 0 & 0 & 0 & 0 & 0 \\
\hline & 2 & 0 & 0 & 0 & 0 & 0 & 0 & 0 & 0 & 0 & 0 & 0 & 0 & 0 & 0 & 0 & 0 \\
\hline & 3 & 0 & 0 & 0 & 0 & 0 & 0 & 0 & 0 & 0 & 1 & 0 & 0 & 0 & 1 & 0 & 0 \\
\hline & 4 & 103 & 15 & 35 & 5 & 5 & 0 & \begin{tabular}{|l|}
66 \\
\end{tabular} & 12 & 13 & 0 & 3 & 1 & 5 & 1 & 15 & 28 \\
\hline & 5 & 0 & 0 & 0 & 0 & 10 & 15 & 0 & 0 & 0 & 0 & 0 & 0 & 0 & 0 & 0 & 0 \\
\hline & 6 & 0 & 0 & 0 & 0 & 0 & 0 & 0 & 0 & 0 & 0 & 7 & 38 & 0 & 6 & 0 & 0 \\
\hline & 7 & 4 & 3 & 9 & 0 & 0 & 0 & 1 & 0 & 0 & 0 & 0 & 0 & 0 & 0 & 0 & 0 \\
\hline & 8 & 47 & 7 & 36 & \begin{tabular}{|l|}
78 \\
\end{tabular} & 47 & 16 & 36 & 140 & 0 & 0 & 0 & 0 & 0 & 0 & 0 & 0 \\
\hline \multirow[t]{8}{*}{77} & 1 & 0 & 0 & 0 & 0 & 0 & 0 & 0 & 0 & 0 & 0 & 0 & 0 & 0 & 0 & 0 & 0 \\
\hline & 2 & 0 & 0 & 0 & 0 & 0 & 0 & 0 & 0 & 0 & 0 & 0 & 0 & 0 & 0 & 0 & 0 \\
\hline & 3 & 0 & 0 & 0 & 0 & 0 & 0 & 0 & 0 & 0 & 0 & 0 & 0 & 0 & 0 & 0 & 0 \\
\hline & 4 & 0 & 0 & 0 & 0 & 0 & 0 & 0 & 0 & 0 & 6 & 0 & 0 & 0 & 0 & 0 & 0 \\
\hline & 5 & 0 & 0 & 0 & 0 & 0 & 0 & 0 & 0 & 0 & 0 & 0 & 0 & 0 & 0 & 0 & 0 \\
\hline & 6 & 48 & 4 & 2 & 0 & 9 & 0 & \begin{tabular}{|l|}
67 \\
\end{tabular} & 7 & 0 & 0 & 0 & 0 & 0 & 0 & 0 & 0 \\
\hline & 7 & 0 & 0 & 0 & 0 & 0 & 0 & 0 & 0 & 1 & 0 & 4 & 1 & 0 & 6 & 2 & 3 \\
\hline & 8 & 77 & 20 & 21 & 5 & 0 & 0 & \begin{tabular}{|l|}
102 \\
\end{tabular} & 6 & 0 & 0 & 0 & 0 & 6 & 3 & 0 & 1 \\
\hline \multirow[t]{8}{*}{81} & 1 & 0 & 0 & 0 & 0 & 0 & 0 & 0 & 0 & 0 & 0 & 0 & 0 & 0 & 0 & 0 & 0 \\
\hline & 2 & 0 & 0 & 0 & 0 & 0 & 0 & 0 & 0 & 0 & 0 & 0 & 0 & 0 & 0 & 0 & 0 \\
\hline & 3 & 0 & 0 & 0 & 0 & 0 & 0 & 0 & 0 & & & & & & & & \\
\hline & 4 & 0 & 0 & 0 & 0 & 0 & 0 & 0 & 0 & 0 & 0 & 5 & 2 & 0 & 0 & 0 & 0 \\
\hline & 5 & 0 & 0 & 0 & 0 & 0 & 0 & 0 & 0 & 0 & 0 & 0 & 0 & 0 & 0 & 0 & 0 \\
\hline & 6 & 0 & 0 & 0 & 0 & 0 & 0 & 0 & 0 & 0 & 0 & 0 & 0 & 0 & 0 & 0 & 0 \\
\hline & 7 & 0 & 0 & 0 & 0 & 0 & 0 & 0 & 0 & 0 & 0 & 0 & 0 & 14 & 2 & 0 & 0 \\
\hline & 8 & 0 & 0 & 0 & 0 & 0 & 0 & 0 & 0 & 0 & 0 & 0 & 0 & 0 & 0 & 0 & 0 \\
\hline \multirow[t]{7}{*}{85} & 1 & 145 & 20 & 194 & 69 & $\mid 162$ & 50 & 196 & 111 & 0 & 3 & 7 & 0 & 0 & 0 & 0 & 0 \\
\hline & 2 & 0 & 0 & 0 & 0 & 0 & 0 & 0 & 0 & 0 & 0 & 0 & 0 & 0 & 0 & 0 & 0 \\
\hline & 3 & 136 & 152 & \begin{tabular}{|l}
67 \\
\end{tabular} & \begin{tabular}{|l|}
89 \\
\end{tabular} & 44 & 7 & \begin{tabular}{|l|}
49 \\
\end{tabular} & \begin{tabular}{|l|}
15 \\
\end{tabular} & 5 & 27 & 6 & 1 & 0 & 6 & 13 & 44 \\
\hline & 4 & 269 & 250 & \begin{tabular}{|l|}
73 \\
\end{tabular} & \begin{tabular}{|l|}
76 \\
\end{tabular} & 72 & 32 & 119 & 30 & 75 & 32 & 76 & 51 & 128 & 261 & 27 & 45 \\
\hline & 5 & 77 & 408 & 230 & 361 & 208 & 233 & \begin{tabular}{|l|}
61 \\
\end{tabular} & \begin{tabular}{|l}
42 \\
\end{tabular} & 3 & 2 & 0 & 0 & 10 & 10 & 4 & 8 \\
\hline & 6 & 51 & 1 & 32 & 10 & 49 & 28 & 32 & 8 & 0 & 0 & 0 & 0 & 0 & 0 & 0 & 0 \\
\hline & 7 & 8 & 0 & 34 & 16 & 9 & 0 & 0 & 0 & 0 & 0 & 0 & 0 & 0 & 0 & 0 & 0 \\
\hline
\end{tabular}




\begin{tabular}{|c|c|c|c|c|c|c|c|c|c|c|c|c|c|c|c|c|c|}
\hline & 8 & 34 & 57 & 248 & 86 & 304 & 322 & 252 & 35 & 8 & 0 & 12 & 20 & 6 & 0 & 5 & 10 \\
\hline \multirow[t]{8}{*}{89} & 1 & 0 & 0 & 0 & 0 & 0 & 0 & 0 & 0 & 0 & 0 & 0 & 0 & 0 & 0 & 0 & 0 \\
\hline & 2 & 0 & 0 & 0 & 0 & 0 & 0 & 0 & 0 & 38 & 66 & 67 & 4 & 17 & 9 & 7 & 9 \\
\hline & 3 & 0 & 0 & 0 & 0 & 0 & 0 & 0 & 0 & 1 & 0 & 0 & 0 & 1 & 0 & 0 & 0 \\
\hline & 4 & 22 & 5 & 0 & 0 & 13 & 18 & 34 & 12 & 0 & 0 & 0 & 0 & 0 & 0 & 0 & 7 \\
\hline & 5 & 502 & 505 & 239 & 31 & 37 & 104 & 4 & 13 & 0 & 0 & 0 & 1 & 0 & 0 & 0 & 0 \\
\hline & 6 & 0 & 0 & 0 & 0 & 0 & 0 & 0 & 0 & 66 & 68 & 6 & 0 & 94 & 17 & 47 & 62 \\
\hline & 7 & 209 & 192 & 169 & 41 & 229 & 79 & 271 & 222 & 7 & 7 & 8 & 21 & 5 & 3 & 13 & 7 \\
\hline & 8 & 9 & 0 & 1 & 0 & 8 & 2 & 10 & 0 & 5 & 2 & 0 & 0 & 0 & 0 & 0 & 1 \\
\hline \multirow[t]{8}{*}{93} & 1 & 17 & 0 & 2 & 0 & 7 & 2 & 35 & 26 & 6 & 13 & 33 & 41 & 24 & 26 & 4 & 8 \\
\hline & 2 & 1 & 2 & 3 & 0 & 3 & 1 & 1 & 0 & 4 & 0 & 1 & 1 & 3 & 0 & 0 & 0 \\
\hline & 3 & 0 & 0 & 0 & 0 & 0 & 0 & 0 & 0 & 0 & 0 & 0 & 0 & 0 & 0 & 0 & 0 \\
\hline & 4 & 19 & 8 & 1 & 0 & 1 & 13 & 18 & 0 & 2 & 13 & 5 & 2 & 2 & 31 & 0 & 2 \\
\hline & 5 & 0 & 0 & 0 & 3 & 1 & 0 & 0 & 1 & 18 & 0 & 3 & 6 & 4 & 1 & 24 & 9 \\
\hline & 6 & 3 & 12 & 0 & 0 & 3 & 0 & 7 & 4 & 127 & 66 & 8 & 0 & 78 & 12 & 84 & 46 \\
\hline & 7 & 5 & 16 & 0 & 0 & 0 & 0 & 1 & 15 & 0 & 0 & 0 & 0 & 1 & 3 & 0 & 0 \\
\hline & 8 & 116 & 255 & 116 & 153 & 55 & 19 & 59 & 76 & 29 & 16 & 62 & 6 & 57 & \begin{tabular}{|l|}
49 \\
\end{tabular} & 35 & 33 \\
\hline \multirow[t]{2}{*}{97} & 1 & 0 & 6 & 30 & 2 & 0 & 0 & 1 & 0 & 0 & 0 & 11 & 5 & 0 & 4 & 1 & 1 \\
\hline & 2 & 6 & 0 & 2 & 0 & 19 & 3 & 4 & 0 & 0 & 0 & 1 & 0 & 0 & 0 & 0 & 0 \\
\hline \multirow[t]{2}{*}{98} & 1 & 3 & 30 & 68 & 3 & 60 & 23 & 47 & 33 & 0 & 0 & 1 & 3 & 0 & 0 & 7 & 0 \\
\hline & 2 & 0 & 0 & 0 & 0 & 0 & 0 & 0 & 0 & 0 & 0 & 0 & 0 & 0 & 0 & 0 & 0 \\
\hline \multirow[t]{2}{*}{99} & 1 & 0 & 0 & 0 & 0 & 0 & 0 & 0 & 0 & 0 & 0 & 0 & 0 & 0 & 0 & 0 & 0 \\
\hline & 2 & 166 & 45 & 112 & 57 & 179 & 166 & 144 & 23 & 0 & 0 & 0 & 0 & 0 & 0 & 0 & 0 \\
\hline \multirow[t]{8}{*}{109} & 1 & 0 & 0 & 2 & 0 & 2 & 1 & 2 & 0 & 120 & 180 & 116 & 134 & 149 & 158 & 80 & 256 \\
\hline & 2 & 0 & 0 & 0 & 0 & 1 & 0 & 0 & 0 & 0 & 0 & 80 & \begin{tabular}{|l|}
97 \\
\end{tabular} & 53 & \begin{tabular}{|l|}
67 \\
\end{tabular} & 26 & 2 \\
\hline & 3 & 177 & 84 & 411 & 250 & 23 & 45 & 43 & 41 & 7 & 3 & 1 & 0 & 6 & 3 & 11 & 5 \\
\hline & 4 & 76 & 102 & 8 & 3 & 119 & 111 & 109 & 29 & 37 & 34 & 561 & 233 & 438 & 426 & 69 & 214 \\
\hline & 5 & 225 & 0 & 160 & 174 & 267 & 414 & 61 & 73 & 0 & 0 & 0 & 0 & 0 & 0 & 0 & 0 \\
\hline & 6 & 86 & 0 & 46 & 31 & 166 & 32 & \begin{tabular}{|l|}
70 \\
\end{tabular} & 5 & 2 & 0 & 0 & 0 & 0 & 0 & 0 & 2 \\
\hline & 7 & 0 & 0 & 0 & 0 & 0 & 0 & 0 & 0 & 0 & 0 & 0 & 1 & 0 & 0 & 3 & 0 \\
\hline & 8 & 153 & 69 & 10 & 7 & 66 & 30 & 80 & 10 & 6 & 0 & 2 & 0 & 26 & 13 & 15 & 13 \\
\hline \multirow[t]{8}{*}{113} & 1 & 0 & 0 & 0 & 0 & 0 & 0 & 0 & 0 & 0 & 0 & 0 & 0 & 0 & 0 & 0 & 0 \\
\hline & 2 & 0 & 0 & 0 & 0 & 0 & 0 & 0 & 0 & 78 & 3 & 130 & 6 & 1 & 0 & 8 & 3 \\
\hline & 3 & 53 & 3 & 2 & 0 & 69 & 20 & 20 & 3 & 49 & 27 & 2 & 3 & 57 & 24 & 156 & \begin{tabular}{|l|}
74 \\
\end{tabular} \\
\hline & 4 & 16 & 109 & 11 & 0 & 18 & 0 & 41 & 56 & 0 & 0 & 0 & 0 & 2 & 2 & 0 & 0 \\
\hline & 5 & 287 & 70 & 117 & 17 & 201 & 340 & 173 & 159 & 12 & 0 & 2 & 0 & 51 & \begin{tabular}{|l|}
63 \\
\end{tabular} & 31 & 21 \\
\hline & 6 & 283 & 108 & 144 & 12 & 93 & 104 & 11 & 2 & 0 & 0 & 0 & 0 & 16 & 12 & 46 & 35 \\
\hline & 7 & 147 & 93 & 39 & 3 & 21 & 53 & 41 & 28 & 10 & 1 & 6 & 23 & 0 & 0 & 12 & 15 \\
\hline & 8 & 6 & 11 & 73 & 174 & 144 & \begin{tabular}{|l|}
71 \\
\end{tabular} & \begin{tabular}{|l|}
70 \\
\end{tabular} & 33 & 0 & 0 & 0 & 0 & 4 & 6 & 6 & 0 \\
\hline \multirow[t]{3}{*}{117} & 1 & 14 & 18 & 8 & 14 & 4 & 0 & 8 & 0 & 0 & 0 & 0 & 0 & 0 & 0 & 0 & 0 \\
\hline & 2 & 0 & 0 & 0 & 0 & 0 & 0 & 0 & 0 & 0 & 0 & 0 & 0 & 0 & 0 & 0 & 0 \\
\hline & 3 & 0 & 0 & 0 & 0 & 0 & 0 & 0 & 0 & 0 & 3 & 0 & 0 & 0 & 0 & 0 & 0 \\
\hline
\end{tabular}




\begin{tabular}{|c|c|c|c|c|c|c|c|c|c|c|c|c|c|c|c|c|c|}
\hline & 4 & 0 & 0 & 0 & 0 & 0 & 0 & 0 & 0 & 0 & 0 & 0 & 0 & 0 & 0 & 0 & 0 \\
\hline & 5 & 0 & 0 & 0 & 0 & 0 & 0 & 0 & 0 & 0 & 0 & 0 & 0 & 0 & 0 & 0 & 0 \\
\hline & 6 & 0 & 0 & 0 & 0 & 0 & 0 & 0 & 0 & 0 & 0 & 0 & 0 & 1 & 0 & 0 & 0 \\
\hline & 7 & 0 & 0 & 0 & 0 & 0 & 0 & 0 & 0 & 0 & 0 & 0 & 0 & 0 & 0 & 0 & 0 \\
\hline & 8 & 0 & 0 & 0 & 0 & 0 & 0 & 0 & 0 & 0 & 0 & 0 & 0 & 0 & 0 & 0 & 0 \\
\hline \multirow[t]{8}{*}{121} & 1 & 0 & 18 & 5 & 2 & 18 & 203 & 0 & 0 & 46 & 14 & 42 & 6 & 49 & 23 & 12 & 5 \\
\hline & 2 & 8 & 7 & 6 & 0 & 19 & 4 & 29 & 12 & 0 & 0 & 0 & 0 & 0 & 0 & 0 & 0 \\
\hline & 3 & 42 & 1 & \begin{tabular}{|l|}
39 \\
\end{tabular} & 8 & 35 & 22 & 119 & 38 & \begin{tabular}{|l|}
10 \\
\end{tabular} & 0 & 2 & \begin{tabular}{|l|}
14 \\
\end{tabular} & 1 & 2 & 4 & 5 \\
\hline & 4 & 208 & 67 & 173 & 61 & 181 & 12 & 48 & 106 & 108 & 53 & 26 & 20 & 60 & 62 & 52 & 3 \\
\hline & 5 & 0 & 0 & 0 & 0 & 0 & 0 & 0 & 1 & 0 & 0 & 0 & 0 & 0 & 0 & 0 & 0 \\
\hline & 6 & 37 & 4 & 48 & 71 & \begin{tabular}{|l|}
64 \\
\end{tabular} & 8 & 19 & 24 & 3 & 11 & 1 & 6 & 0 & 0 & 6 & 5 \\
\hline & 7 & 0 & 0 & 0 & 0 & 0 & 0 & 0 & 0 & 0 & 0 & 0 & 0 & 0 & 0 & 0 & 0 \\
\hline & 8 & 0 & 0 & 0 & 0 & 0 & 0 & 0 & 0 & 0 & 0 & 0 & 0 & 0 & 0 & 0 & 0 \\
\hline \multirow[t]{8}{*}{125} & 1 & 72 & 0 & \begin{tabular}{|l}
17 \\
\end{tabular} & 0 & 12 & 0 & 21 & 0 & 0 & 0 & 0 & 0 & 0 & 0 & 0 & 1 \\
\hline & 2 & 1 & 1 & 4 & 11 & 25 & 10 & 2 & 4 & 1 & 9 & 2 & 1 & 4 & 8 & 1 & 20 \\
\hline & 3 & 0 & 11 & 0 & 4 & 19 & 3 & 3 & 9 & 9 & 11 & 4 & 0 & 1 & 0 & 14 & 16 \\
\hline & 4 & 32 & 28 & \begin{tabular}{|l|}
99 \\
\end{tabular} & 51 & \begin{tabular}{|l|}
78 \\
\end{tabular} & 151 & 91 & 149 & \begin{tabular}{|l|}
11 \\
\end{tabular} & 3 & 2 & 0 & 6 & 3 & 4 & 19 \\
\hline & 5 & 0 & 0 & 0 & 0 & 0 & 0 & 0 & 0 & 0 & 0 & 4 & 0 & 6 & 1 & 8 & 11 \\
\hline & 6 & 0 & 3 & 0 & 0 & 0 & 0 & 0 & 0 & 0 & 0 & 0 & 0 & 0 & 0 & 0 & 0 \\
\hline & 7 & 5 & 2 & 6 & 4 & \begin{tabular}{|l|}
94 \\
\end{tabular} & 105 & 87 & 31 & 11 & 26 & 5 & 5 & 15 & 9 & 13 & 25 \\
\hline & 8 & 189 & 22 & 120 & 7 & 162 & 154 & 231 & 185 & 45 & 39 & 55 & 114 & 63 & 94 & 79 & 77 \\
\hline \multirow[t]{8}{*}{129} & 1 & 102 & 14 & 48 & 2 & 79 & 92 & 39 & 1 & 5 & 0 & 0 & 0 & 4 & 0 & 0 & 0 \\
\hline & 2 & 63 & 6 & 0 & 3 & 6 & 4 & 10 & 8 & 18 & 3 & 7 & 3 & 8 & 2 & 9 & 6 \\
\hline & 3 & 59 & 199 & 3 & 5 & 153 & 111 & 229 & 117 & 0 & 0 & 25 & 8 & 1 & 3 & 0 & 0 \\
\hline & 4 & 0 & 0 & 0 & 0 & 0 & 0 & 0 & 0 & 4 & 2 & 0 & 0 & 0 & 0 & 0 & 0 \\
\hline & 5 & 1 & 10 & 0 & 0 & 0 & 4 & 9 & 0 & 1 & 8 & 0 & 0 & 0 & 0 & 18 & 13 \\
\hline & 6 & 0 & 2 & 8 & 16 & 0 & 0 & 0 & 0 & 0 & 0 & 0 & 0 & 0 & 0 & 0 & 0 \\
\hline & 7 & 37 & 6 & 63 & 56 & 32 & 12 & 80 & 51 & 12 & 23 & 2 & 0 & 13 & 1 & 15 & 21 \\
\hline & 8 & 0 & 0 & 0 & 0 & 0 & 0 & 0 & 0 & 1 & 0 & 10 & 0 & 6 & 9 & 0 & 0 \\
\hline \multirow[t]{2}{*}{133} & 1 & 12 & 5 & 0 & 0 & 0 & 0 & 10 & 0 & 0 & 0 & 0 & 0 & 0 & 0 & 0 & 0 \\
\hline & 2 & 26 & 8 & 0 & 0 & 15 & 3 & 13 & 6 & 0 & 0 & 0 & 0 & 0 & 0 & 0 & 0 \\
\hline \multirow[t]{2}{*}{134} & 1 & 2 & 1 & 0 & 0 & 0 & 0 & 1 & 0 & 5 & 2 & 2 & 7 & 0 & 0 & 0 & 5 \\
\hline & 2 & 0 & 0 & 0 & 0 & 0 & 0 & 0 & 0 & 0 & 0 & 0 & 3 & 11 & 2 & 3 & 8 \\
\hline \multirow[t]{2}{*}{135} & 1 & 172 & 26 & 119 & 35 & 194 & 254 & 144 & 230 & 3 & 4 & 0 & 0 & 0 & 0 & 0 & 2 \\
\hline & 2 & 0 & 0 & 0 & 0 & 0 & 0 & 0 & 0 & 10 & 0 & 6 & 0 & 2 & 0 & 2 & 16 \\
\hline \multirow[t]{7}{*}{145} & 1 & 0 & 0 & 0 & 0 & 0 & 0 & 0 & 0 & 0 & 0 & 0 & 0 & 0 & 0 & 0 & 0 \\
\hline & 2 & 10 & 12 & 19 & 24 & 30 & 6 & 49 & 18 & 1 & 0 & 0 & 0 & 0 & 0 & 1 & 2 \\
\hline & 3 & 0 & 0 & 0 & 0 & 0 & 0 & 0 & 0 & 0 & 0 & 0 & 0 & 0 & 0 & 0 & 1 \\
\hline & 4 & 32 & 70 & \begin{tabular}{|l|}
14 \\
\end{tabular} & 22 & 7 & 0 & 24 & 16 & 6 & 10 & 2 & 2 & 6 & 8 & 8 & 16 \\
\hline & 5 & 0 & 15 & 1 & 6 & 10 & 0 & 6 & 5 & 0 & 0 & 0 & 0 & 0 & 0 & 0 & 0 \\
\hline & 6 & 0 & 0 & 0 & 0 & 0 & 0 & 0 & 0 & 0 & 0 & 0 & 0 & 0 & 0 & 0 & 0 \\
\hline & 7 & 2 & 3 & 31 & 32 & \begin{tabular}{|l|}
38 \\
\end{tabular} & 58 & \begin{tabular}{|l}
17 \\
\end{tabular} & 50 & 6 & 14 & 4 & 5 & 0 & 0 & 21 & 38 \\
\hline
\end{tabular}




\begin{tabular}{|c|c|c|c|c|c|c|c|c|c|c|c|c|c|c|c|c|c|}
\hline & 8 & 0 & 0 & 0 & 0 & 0 & 0 & 0 & 0 & 0 & 0 & 0 & 0 & 0 & 0 & 0 & 0 \\
\hline \multirow[t]{8}{*}{149} & 1 & 0 & 0 & 6 & 2 & 5 & 4 & 3 & 1 & 0 & 1 & 0 & 0 & 0 & 2 & 4 & 3 \\
\hline & 2 & 0 & 0 & 0 & 0 & 0 & 0 & 0 & 0 & 0 & 0 & 0 & 0 & 5 & 12 & 2 & 0 \\
\hline & 3 & 0 & 0 & 0 & 0 & 0 & 0 & 0 & 0 & 0 & 1 & 4 & 0 & 0 & 0 & 0 & 13 \\
\hline & 4 & 0 & 0 & 0 & 0 & 0 & 0 & 0 & 0 & 0 & 0 & 0 & 0 & 0 & 0 & 0 & 0 \\
\hline & 5 & 10 & 10 & 0 & 3 & 27 & 26 & \begin{tabular}{|l|}
18 \\
\end{tabular} & 11 & 10 & 0 & 8 & 4 & 4 & 27 & 12 & 0 \\
\hline & 6 & 7 & 35 & 0 & 0 & 13 & 2 & \begin{tabular}{|l|}
69 \\
\end{tabular} & 53 & 95 & 148 & 39 & 0 & 16 & 8 & 113 & 43 \\
\hline & 7 & 0 & 0 & 0 & 0 & 0 & 0 & 0 & 0 & 0 & 0 & 0 & 0 & 0 & 0 & 0 & 0 \\
\hline & 8 & 0 & 0 & 0 & 0 & 0 & 0 & 0 & 0 & 0 & 0 & 0 & 0 & 0 & 0 & 1 & 0 \\
\hline \multirow[t]{8}{*}{153} & 1 & 0 & 0 & 0 & 0 & 0 & 0 & 0 & 0 & 0 & 0 & 0 & 0 & 0 & 0 & 0 & 0 \\
\hline & 2 & 0 & 0 & 0 & 0 & 0 & 0 & 0 & 0 & 0 & 0 & 0 & 0 & 0 & 0 & 0 & 0 \\
\hline & 3 & 0 & 0 & 0 & 0 & 0 & 0 & 0 & 0 & 0 & 0 & 0 & 0 & 0 & 0 & 0 & 0 \\
\hline & 4 & 0 & 0 & 0 & 0 & 0 & 0 & 0 & 0 & 0 & 0 & 0 & 0 & 0 & 0 & 0 & 0 \\
\hline & 5 & 0 & 0 & 0 & 0 & 0 & 0 & 0 & 0 & 0 & 0 & 0 & 0 & 0 & 0 & 0 & 0 \\
\hline & 6 & 0 & 0 & 0 & 0 & 0 & 0 & 0 & 0 & 0 & 0 & 0 & 0 & 0 & 0 & 0 & 0 \\
\hline & 7 & 0 & 0 & 0 & 0 & 0 & 0 & 0 & 0 & 0 & 0 & 0 & 0 & 0 & 0 & 0 & 0 \\
\hline & 8 & 0 & 0 & 0 & 0 & 0 & 0 & 0 & 0 & 0 & 0 & 0 & 0 & 0 & 0 & 0 & 0 \\
\hline \multirow[t]{8}{*}{157} & 1 & 43 & 15 & 29 & 7 & 31 & 2 & 14 & 1 & 1 & 0 & 0 & 0 & 27 & 21 & 19 & 12 \\
\hline & 2 & 0 & 0 & 0 & 0 & 0 & 0 & 0 & 0 & 0 & 0 & 0 & 0 & 0 & 0 & 0 & 0 \\
\hline & 3 & 0 & 0 & 0 & 0 & 0 & 0 & 0 & 0 & 0 & 0 & 0 & 0 & 0 & 0 & 0 & 0 \\
\hline & 4 & 3 & 4 & 0 & 0 & 0 & 0 & 0 & 0 & 0 & 0 & 0 & 0 & 0 & 0 & 0 & 0 \\
\hline & 5 & 17 & 6 & 26 & 3 & 2 & 6 & 0 & 0 & 5 & 0 & 11 & 6 & 0 & 0 & 1 & 2 \\
\hline & 6 & 0 & 0 & 0 & 0 & 0 & 0 & 0 & 0 & 0 & 0 & 0 & 0 & 0 & 0 & 0 & 0 \\
\hline & 7 & 0 & 0 & 0 & 0 & 0 & 0 & 0 & 0 & 4 & 0 & 0 & 0 & 0 & 0 & 0 & 0 \\
\hline & 8 & 89 & 511 & 340 & 204 & \begin{tabular}{|l|}
444 \\
\end{tabular} & 94 & \begin{tabular}{|l|}
173 \\
\end{tabular} & 337 & 0 & 0 & 0 & 0 & 0 & 0 & 0 & 0 \\
\hline \multirow[t]{8}{*}{161} & 1 & 0 & 0 & 0 & 0 & 0 & 0 & 0 & 0 & 5 & 0 & 0 & 2 & 1 & 2 & 2 & 3 \\
\hline & 2 & 0 & 0 & 0 & 0 & 0 & 0 & 0 & 0 & 0 & 0 & 0 & 0 & 0 & 0 & 0 & 0 \\
\hline & 3 & 0 & 0 & 0 & 0 & 0 & 0 & 0 & 0 & 0 & 0 & 0 & 0 & 0 & 0 & 0 & 0 \\
\hline & 4 & 46 & 15 & 44 & 13 & 25 & 107 & \begin{tabular}{|l|}
63 \\
\end{tabular} & \begin{tabular}{|l|}
68 \\
\end{tabular} & 71 & \begin{tabular}{|l|}
87 \\
\end{tabular} & 21 & 12 & 3 & 2 & 7 & 1 \\
\hline & 5 & 309 & 55 & 75 & 2 & 225 & 238 & 350 & \begin{tabular}{|l|}
86 \\
\end{tabular} & 0 & 0 & 0 & 0 & 0 & 0 & 2 & 0 \\
\hline & 6 & 9 & 2 & 11 & 100 & 5 & 22 & 9 & \begin{tabular}{|l|}
12 \\
\end{tabular} & 0 & 0 & 0 & 0 & 0 & 0 & 0 & 0 \\
\hline & 7 & 0 & 0 & 0 & 9 & 0 & 0 & 0 & 0 & 0 & 0 & 0 & 0 & 0 & 0 & 0 & 0 \\
\hline & 8 & 0 & 0 & 0 & 0 & 0 & 0 & 0 & 0 & 16 & 0 & 137 & 94 & 4 & 45 & 37 & 36 \\
\hline \multirow[t]{8}{*}{165} & 1 & 0 & 0 & 0 & 0 & 0 & 0 & 0 & 0 & 9 & 0 & 12 & 5 & 3 & 17 & 1 & 0 \\
\hline & 2 & 0 & 0 & 0 & 0 & 0 & 0 & 0 & 0 & 0 & 0 & 0 & 0 & 0 & 0 & 0 & 0 \\
\hline & 3 & 0 & 0 & 0 & 0 & 0 & 0 & 0 & 0 & 0 & 0 & 0 & 0 & 0 & 0 & 0 & 0 \\
\hline & 4 & 367 & 177 & 346 & 125 & 190 & 192 & 246 & 262 & 0 & 0 & 0 & 0 & 0 & 0 & 0 & 0 \\
\hline & 5 & 0 & 0 & 0 & 0 & 0 & 0 & 0 & 0 & 0 & 0 & 0 & 0 & 0 & 0 & 0 & 0 \\
\hline & 6 & 0 & 0 & 0 & 0 & 0 & 0 & 0 & 0 & 23 & 54 & 0 & 0 & 0 & 0 & 22 & 2 \\
\hline & 7 & 0 & 0 & 0 & 0 & 0 & 0 & 0 & 0 & 0 & 0 & 0 & 0 & 0 & 0 & 0 & 0 \\
\hline & 8 & 0 & 0 & 0 & 0 & 0 & 0 & 0 & 0 & 0 & 0 & 0 & 5 & 0 & 2 & 0 & 0 \\
\hline 169 & 1 & 0 & 0 & 0 & 0 & 0 & 0 & 0 & 0 & 0 & 1 & 6 & 1 & 42 & 0 & 36 & 95 \\
\hline
\end{tabular}




\begin{tabular}{|c|c|c|c|c|c|c|c|c|c|c|c|c|c|c|c|c|c|}
\hline & 2 & 0 & 0 & 1 & 0 & 0 & 0 & 2 & 0 & 0 & 0 & 0 & 0 & 0 & 0 & 0 & 0 \\
\hline \multirow[t]{2}{*}{170} & 1 & 0 & 0 & 0 & 0 & 0 & 0 & 0 & 0 & 0 & 0 & 0 & 0 & 0 & 0 & 0 & 0 \\
\hline & 2 & 0 & 0 & 0 & 0 & 0 & 0 & 0 & 0 & 0 & 0 & 0 & 0 & 0 & 1 & 0 & 0 \\
\hline \multirow[t]{2}{*}{171} & 1 & 0 & 0 & 0 & 0 & 0 & 0 & 0 & 0 & 9 & 0 & 3 & 0 & 0 & 0 & 0 & 0 \\
\hline & 2 & 0 & 6 & 4 & 0 & 2 & 0 & 23 & 13 & 0 & 0 & 0 & 0 & 0 & 0 & 0 & 0 \\
\hline \multirow[t]{8}{*}{181} & 1 & 0 & 0 & 0 & 0 & 0 & 0 & 0 & 0 & 0 & 0 & 0 & 0 & 0 & 0 & 0 & 0 \\
\hline & 2 & 0 & 0 & 0 & 0 & 0 & 0 & 0 & 0 & 0 & 0 & 0 & 0 & 0 & 0 & 0 & 0 \\
\hline & 3 & 63 & 6 & 2 & 1 & 29 & 1 & 120 & 31 & 0 & 0 & 0 & 0 & 0 & 0 & 0 & 0 \\
\hline & 4 & 0 & 0 & 0 & 0 & 0 & 0 & 0 & 0 & 0 & 0 & 0 & 0 & 0 & 0 & 0 & 0 \\
\hline & 5 & 0 & 0 & 0 & 0 & 0 & 0 & 0 & 0 & 0 & 0 & 0 & 0 & 0 & 0 & 0 & 0 \\
\hline & 6 & 0 & 0 & 0 & 0 & 0 & 0 & 0 & 0 & 0 & 0 & 0 & 0 & 0 & 0 & 0 & 0 \\
\hline & 7 & 86 & 14 & 5 & 1 & 6 & 3 & 93 & 118 & 1 & 6 & 2 & 25 & 2 & 1 & 1 & 0 \\
\hline & 8 & 66 & 40 & 21 & 15 & 51 & 33 & 72 & 35 & 0 & 0 & 0 & 0 & 10 & 4 & 0 & 0 \\
\hline \multirow[t]{8}{*}{185} & 1 & 3 & 0 & 0 & 0 & 0 & 0 & 1 & 0 & 0 & 0 & 0 & 0 & 0 & 0 & 0 & 0 \\
\hline & 2 & 0 & 0 & 0 & 0 & 0 & 0 & 0 & 0 & 0 & 0 & 0 & 0 & 0 & 0 & 0 & 0 \\
\hline & 3 & 0 & 0 & 0 & 0 & 5 & 0 & 9 & 12 & 0 & 0 & 0 & 0 & 0 & 0 & 0 & 0 \\
\hline & 4 & 5 & 2 & 3 & 0 & 0 & 0 & 6 & 0 & 43 & 28 & 6 & 0 & 18 & 7 & 44 & 17 \\
\hline & 5 & 0 & 2 & 14 & 19 & 13 & 3 & 28 & 3 & 0 & 0 & 0 & 0 & 0 & 1 & 0 & 0 \\
\hline & 6 & 1 & 0 & 0 & 0 & 6 & 1 & 6 & 1 & 0 & 0 & 0 & 0 & 0 & 0 & 0 & 0 \\
\hline & 7 & 3 & 0 & 4 & 0 & 0 & 6 & 0 & 0 & 0 & 0 & 0 & 0 & 0 & 0 & 0 & 0 \\
\hline & 8 & 13 & 6 & 5 & 1 & 3 & 0 & 17 & 9 & 0 & 0 & 0 & 0 & 0 & 0 & 0 & 0 \\
\hline \multirow[t]{8}{*}{189} & 1 & 0 & 0 & 0 & 0 & 0 & 0 & 0 & 0 & 0 & 0 & 0 & 0 & 0 & 0 & 0 & 0 \\
\hline & 2 & 0 & 0 & 0 & 0 & 0 & 0 & 0 & 0 & 0 & 0 & 0 & 0 & 0 & 0 & 0 & 0 \\
\hline & 3 & 0 & 0 & 0 & 0 & 0 & 0 & 0 & 0 & 0 & 0 & 0 & 0 & 0 & 0 & 0 & 0 \\
\hline & 4 & 0 & 0 & 0 & 0 & 0 & 0 & 0 & 0 & 0 & 0 & 0 & 0 & 0 & 0 & 0 & 0 \\
\hline & 5 & 0 & 0 & 0 & 0 & 0 & 0 & 0 & 0 & 0 & 0 & 0 & 0 & 0 & 0 & 0 & 0 \\
\hline & 6 & 0 & 0 & 0 & 0 & 0 & 0 & 0 & 0 & 0 & 0 & 0 & 0 & 0 & 0 & 0 & 0 \\
\hline & 7 & 0 & 0 & 0 & 0 & 0 & 0 & 0 & 0 & 17 & 0 & 36 & 132 & 4 & 0 & 7 & 20 \\
\hline & 8 & 0 & 0 & 0 & 0 & 0 & 0 & 0 & 0 & 0 & 0 & 0 & 0 & 0 & 0 & 0 & 0 \\
\hline \multirow[t]{8}{*}{193} & 1 & 1 & 1 & 1 & 0 & 0 & 0 & 0 & 0 & 0 & 0 & 0 & 0 & 0 & 0 & 0 & 0 \\
\hline & 2 & 0 & 0 & 0 & 0 & 0 & 0 & 0 & 0 & 0 & 0 & 0 & 0 & 0 & 0 & 0 & 0 \\
\hline & 3 & 382 & 288 & 218 & 109 & 328 & 41 & 564 & 350 & 0 & 0 & 0 & 0 & 0 & 0 & 0 & 0 \\
\hline & 4 & 0 & 0 & 0 & 0 & 0 & 0 & 0 & 0 & 2 & 1 & 0 & 0 & 1 & 11 & 1 & 0 \\
\hline & 5 & 0 & 0 & 0 & 0 & 0 & 0 & 0 & 0 & 2 & 0 & 0 & 0 & 0 & 0 & 9 & 4 \\
\hline & 6 & 42 & 87 & \begin{tabular}{|l|}
70 \\
\end{tabular} & 149 & \begin{tabular}{|l|}
124 \\
\end{tabular} & \begin{tabular}{|l|}
95 \\
\end{tabular} & 147 & 368 & 0 & 0 & 0 & 0 & 0 & 0 & 0 & 0 \\
\hline & 7 & 18 & 1 & 44 & 32 & \begin{tabular}{|l|}
123 \\
\end{tabular} & 21 & 59 & 19 & 0 & 0 & 0 & 0 & 0 & 0 & 0 & 0 \\
\hline & 8 & 0 & 0 & 4 & 0 & 16 & 3 & 9 & 4 & 1 & 2 & 6 & 0 & 0 & 0 & 2 & 2 \\
\hline \multirow[t]{5}{*}{197} & 1 & 83 & 112 & 11 & 9 & 256 & 136 & 276 & 156 & 8 & 5 & 17 & 11 & 3 & 0 & 0 & 0 \\
\hline & 2 & 0 & 0 & 0 & 0 & 0 & 0 & 0 & 0 & 25 & 6 & 1 & 3 & 2 & 7 & 19 & 11 \\
\hline & 3 & 79 & 33 & 60 & 5 & 127 & 32 & 116 & 65 & 36 & 31 & 4 & 0 & 0 & 0 & 26 & 3 \\
\hline & 4 & 0 & 0 & 0 & 2 & \begin{tabular}{|l|}
269 \\
\end{tabular} & 149 & 23 & 43 & 5 & 7 & 3 & 0 & 59 & 20 & 13 & 11 \\
\hline & 5 & 0 & 0 & 0 & 4 & 0 & 0 & 0 & 0 & 3 & 8 & 10 & 5 & 21 & 0 & 1 & 10 \\
\hline
\end{tabular}




\begin{tabular}{|c|c|c|c|c|c|c|c|c|c|c|c|c|c|c|c|c|c|}
\hline & 6 & 215 & 215 & 44 & 2 & 3 & 0 & 243 & 89 & 0 & 47 & 19 & 5 & 12 & 9 & 0 & 0 \\
\hline & 7 & 0 & 0 & 0 & 0 & 0 & 0 & 0 & 0 & 0 & 0 & 0 & 0 & 0 & 0 & 0 & 0 \\
\hline & 8 & 52 & 4 & 22 & 0 & 229 & 173 & 14 & 0 & 13 & 9 & 2 & 9 & 10 & 0 & 5 & 10 \\
\hline $\mathbf{2 0 1}$ & 1 & 10 & 6 & 13 & 7 & 83 & 42 & 14 & 0 & 0 & 3 & 0 & 0 & 0 & 0 & 0 & 0 \\
\hline & 2 & 0 & 1 & 7 & 22 & 6 & 3 & 6 & 0 & 0 & 0 & 0 & 0 & 0 & 0 & 0 & 0 \\
\hline & 3 & 0 & 0 & 0 & 0 & 0 & 0 & 0 & 0 & 0 & 0 & 0 & 0 & 0 & 0 & 0 & 0 \\
\hline & 4 & 0 & 0 & 0 & 0 & 0 & 0 & 0 & 0 & 0 & 0 & 0 & 0 & 0 & 0 & 0 & 0 \\
\hline & 5 & 92 & 221 & 301 & 143 & 49 & 98 & 1 & 13 & 4 & 0 & 4 & 0 & 8 & 0 & 0 & 8 \\
\hline & 6 & 0 & 0 & 0 & 0 & 9 & 23 & 0 & 0 & 8 & 1 & 2 & 0 & 7 & 8 & 1 & 9 \\
\hline & 7 & 0 & 0 & 0 & 0 & 0 & 0 & 0 & 0 & 0 & 0 & 0 & 0 & 0 & 0 & 0 & 0 \\
\hline & 8 & 4 & 26 & 13 & 14 & 2 & 5 & 5 & 16 & 0 & 0 & 0 & 0 & 0 & 0 & 0 & 0 \\
\hline $\mathbf{2 0 5}$ & 1 & 9 & 29 & 22 & 10 & 28 & 51 & 10 & 0 & 0 & 0 & 0 & 0 & 0 & 0 & 0 & 0 \\
\hline & 2 & 24 & 0 & 0 & 0 & 0 & 0 & 8 & 0 & 0 & 0 & 0 & 0 & 0 & 0 & 0 & 0 \\
\hline $\mathbf{2 0 6}$ & 1 & 0 & 0 & 0 & 0 & 0 & 0 & 0 & 0 & 0 & 0 & 0 & 0 & 0 & 0 & 0 & 0 \\
\hline & 2 & 0 & 0 & 0 & 0 & 5 & 13 & 3 & 4 & 30 & 29 & 0 & 0 & 0 & 0 & 14 & 4 \\
\hline $\mathbf{2 0 7}$ & 1 & 0 & 0 & 0 & 0 & 0 & 0 & 0 & 0 & 0 & 0 & 0 & 0 & 0 & 0 & 0 & 0 \\
\hline & 2 & 0 & 0 & 0 & 0 & 0 & 0 & 0 & 0 & 0 & 0 & 0 & 0 & 0 & 0 & 0 & 0 \\
\hline
\end{tabular}




\section{ANEJO 5}

Resultados de cuantificación por Taqman PCR

\begin{tabular}{|c|c|c|c|c|}
\hline & & $x 50$ & & \\
\hline Taq & $\mathrm{fg} / 2 \mathrm{ul}$ & $\mathrm{fg} / 100 \mathrm{ul}$ & peso [mg] & $\begin{array}{l}\text { mg peso } \\
\text { seco }\end{array}$ \\
\hline 1 & 186890,6 & 9344531 & 12 & 778710,875 \\
\hline 5 & 116479,6 & 5823982 & 10,7 & 544297,3364 \\
\hline 9 & 60813,29 & 3040665 & 11 & 276424,0455 \\
\hline 13 & 94564,17 & 4728209 & 10,6 & 446057,4057 \\
\hline 17 & 40962,05 & 2048103 & 12,5 & 163848,2 \\
\hline 21 & 167011,2 & 8350561 & 12,4 & 673432,3387 \\
\hline 25 & 98108,38 & 4905419 & 11 & 445947,1818 \\
\hline 26 & 121372,3 & 6068614 & 10,3 & 589185,8252 \\
\hline 27 & 119616,7 & 5980833 & 11,2 & 534002,9464 \\
\hline 37 & 14149,77 & 707488,5 & 12,1 & 58470,12397 \\
\hline 41 & 10083,53 & 504176,5 & 11,8 & 42726,82203 \\
\hline 45 & 7053,07 & 352653,5 & 11,4 & 30934,51754 \\
\hline 49 & 12586,57 & 629328,5 & 12 & 52444,04167 \\
\hline 53 & 11522,99 & 576149,5 & 10,6 & 54353,72642 \\
\hline 57 & 7338,02 & 366901 & 11,5 & 31904,43478 \\
\hline 61 & 31638,33 & 1581917 & 11,6 & 136372,1121 \\
\hline 62 & 18527,58 & 926379 & 11,3 & 81980,44248 \\
\hline 63 & 17127,84 & 856392 & 10,9 & 78568,07339 \\
\hline 73 & 196322,4 & 9816120 & 11,6 & 846217,1983 \\
\hline 77 & 164470,4 & 8223519 & 12,2 & 674058,9344 \\
\hline 81 & 107363,6 & 5368178 & 11,2 & 479301,6071 \\
\hline 85 & 325262,2 & 16263111 & 12,3 & 1322204,146 \\
\hline 89 & 128213,7 & 6410686 & 11,5 & 557450,913 \\
\hline 93 & 179336,7 & 8966834 & 10,6 & 845927,6887 \\
\hline 97 & 61446,34 & 3072317 & 11,5 & 267158 \\
\hline 98 & 149789,4 & 7489471 & 12,4 & 603989,5565 \\
\hline 99 & 182578,2 & 9128910 & 10,6 & 861217,8774 \\
\hline 109 & 26778,29 & 1338915 & 10,7 & 125132,1963 \\
\hline 113 & 14226,45 & 711322,5 & 11,4 & 62396,71053 \\
\hline 117 & 7292,03 & 364601,5 & 11,8 & 30898,4322 \\
\hline 121 & 5837,59 & 291879,5 & 10,8 & 27025,87963 \\
\hline 125 & 13446,61 & 672330,5 & 12,6 & 53359,56349 \\
\hline 129 & 6069,61 & 303480,5 & 10,6 & 28630,23585 \\
\hline 133 & 13376,19 & 668809,5 & 12,3 & 54374,7561 \\
\hline 134 & 7584,23 & 379211,5 & 12,1 & 31339,79339 \\
\hline
\end{tabular}




$\begin{array}{rrrrr}135 & 28709,07 & 1435454 & 12,2 & 117660,123 \\ 145 & 246543,1 & 12327153 & 10,6 & 1162938,915 \\ 149 & 38872,55 & 1943628 & 10,7 & 181647,4299 \\ 153 & 67004,16 & 3350208 & 11,6 & 288811,0345 \\ 157 & 367232,5 & 18361627 & 10,9 & 1684552,89 \\ 161 & 71391,55 & 3569578 & 11,9 & 299964,4958 \\ 165 & 85124,72 & 4256236 & 11,4 & 373354,0351 \\ 169 & 377700,3 & 18885016 & 11,1 & 1701352,748 \\ 170 & 82714,02 & 4135701 & 10,9 & 379422,1101 \\ 171 & 192438,7 & 9621933 & 12,8 & 751713,5156 \\ 181 & 12150,65 & 607532,5 & 11,8 & 51485,80508 \\ 185 & 7083,21 & 354160,5 & 12,2 & 29029,54918 \\ 189 & 1282,5 & 64125 & 11,1 & 5777,027027 \\ 193 & 8343,98 & 417199 & 11,6 & 35965,43103 \\ 197 & 7230,19 & 361509,5 & 12,1 & 29876,81818 \\ 201 & 18064,94 & 903247 & 10,8 & 83633,98148 \\ 205 & 12248,81 & 612440,5 & 11,9 & 51465,58824 \\ 206 & 13676,78 & 683839 & 11,4 & 59985,87719 \\ 207 & 7271,29 & 363564,5 & 12,4 & 29319,71774 \\ 217 & 2124,98 & 106249 & 10,7 & 9929,813084 \\ 218 & 1863,23 & 93161,5 & 10,8 & 8626,064815 \\ 219 & 2853,78 & 142689 & 12,4 & 11507,17742 \\ 220 & 3347,72 & 167386 & 10,8 & 15498,7037 \\ 221 & 3691,53 & 184576,5 & 12,2 & 15129,22131 \\ 222 & 3123,09 & 156154,5 & 11,7 & 13346,53846 \\ 223 & 2651,09 & 132554,5 & 10,9 & 12160,9633 \\ 224 & 1843,93 & 92196,5 & 12,5 & 7375,72 \\ 225 & 1706,99 & 85349,5 & 11 & 7759,045455 \\ 226 & 3328,49 & 166424,5 & 12,3 & 13530,44715 \\ 227 & 3793,47 & 189673,5 & 11,4 & 16638,02632 \\ 228 & 2530,15 & 126507,5 & 10,7 & 11823,13084\end{array}$


A. Procesado de datos para el tiempo de muestreo T0

\begin{tabular}{|lrrrr|}
\hline T0 & & & \\
& A & & B & \\
& & 9930 & & 12161 \\
& & 8626 & & 7376 \\
& 11507 & & 7759 \\
& 15499 & 13530 \\
& 15129 & & 16638 \\
& & 13347 & 11823 \\
\cline { 2 - 4 } Media & $\mathbf{1 2 3 4 0}$ & & $\mathbf{1 1 5 4 8}$ \\
\hline
\end{tabular}

B. Procesado de datos para el tiempo de muestreo T1

\begin{tabular}{|c|c|c|c|c|c|}
\hline \multicolumn{6}{|l|}{ T1 } \\
\hline \multirow[t]{10}{*}{ A } & Bloque1 & Bloque2 & Bloque3 & & Media \\
\hline & 778711 & 846217 & 1162939 & Prophyta & 929289 \\
\hline & 544297 & 674059 & 181647 & B255 & 466668 \\
\hline & 276424 & 479302 & 288811 & Urea & 348179 \\
\hline & 446057 & 1322204 & 1684553 & Erwinia & 1150938 \\
\hline & 163848 & 557451 & 299964 & Coniothy & 340421 \\
\hline & 673432 & 845928 & 373354 & Control & 630905 \\
\hline & 445947 & 267158 & 1701353 & Pack top & 804819 \\
\hline & 589186 & 603990 & 379422 & Pack middle & 524199 \\
\hline & 534003 & 861218 & 751714 & Pack bottom & 715645 \\
\hline \multicolumn{6}{|l|}{ B } \\
\hline & 58470 & 125132 & 51486 & Prophyta & 78363 \\
\hline & 42727 & 62397 & 29030 & B255 & 44718 \\
\hline & 30935 & 30898 & 5777 & Urea & 22537 \\
\hline & 52444 & 27026 & 35965 & Erwinia & 38478 \\
\hline & 54354 & 53360 & 29877 & Coniothy & 45863 \\
\hline & 31904 & 28630 & 83634 & Control & 48056 \\
\hline & 136372 & 54375 & 51466 & Pack top & 80737 \\
\hline & 81980 & 31340 & 59986 & Pack middle & 57769 \\
\hline & 78568 & 117660 & 29320 & Pack bottom & 75183 \\
\hline
\end{tabular}





\section{ANEJO 6}

Tabla resumen de resultados del ensayo en campo

\begin{tabular}{|c|c|c|c|c|c|c|}
\hline ue & LOC. & TRATAM. & $\begin{array}{c}\text { Superf. } \\
\text { dañada } \mathrm{mm}^{2}\end{array}$ & ESPORAS $(\log (x+1)$ & $\mathrm{DNA}(\mathrm{fg} / \mathrm{mg})$ & \%DESC. \\
\hline 1 & A & Prophyta & 16536,4375 & 1,801606045 & 778711 & 15,05628 \\
\hline 1 & A & B255 & 2570,25 & 0,544123924 & 544297 & 14,15235 \\
\hline 1 & A & Urea & 1793,875 & 0,627581862 & 276424 & 8,964905 \\
\hline 1 & A & Erwinia & 4067,5625 & 2,157901899 & 446057 & 9,519689 \\
\hline 1 & A & Coniothyr. & 2493,75 & 1,683432195 & 163848 & 11,10107 \\
\hline 1 & A & Control & 5182,875 & 0,693383096 & 673432 & 9,837282 \\
\hline 2 & A & Prophyta & 4580,109375 & 1,074668744 & 846217 & 10,39729 \\
\hline 2 & A & B255 & 2809,875 & 0,768687966 & 674059 & 9,812598 \\
\hline 2 & A & Urea & 1799,609375 & 0,111110791 & 479302 & 18,56117 \\
\hline 2 & A & Erwinia & 10173,34375 & 1,916401392 & 1322204 & 16,09201 \\
\hline 2 & A & Coniothyr. & 1709,25 & 1,669918193 & 557451 & 10,86614 \\
\hline 2 & A & Control & 5223,9375 & 1,417700754 & 845928 & 15,79865 \\
\hline 3 & A & Prophyta & 2384,25 & 1,032568631 & 1162939 & 15,50225 \\
\hline 3 & A & B255 & 611,5625 & 1,07868279 & 181647 & 14,92692 \\
\hline 3 & A & Urea & 1373,125 & 0 & 288811 & 20,39336 \\
\hline 3 & A & Erwinia & 8657,25 & 1,491583224 & 1684553 & 14,90685 \\
\hline 3 & A & Coniothyr. & 1124,484375 & 1,505257491 & 299964 & 15,70255 \\
\hline 3 & A & Control & 1340,390625 & 1,430267683 & 373354 & 17,77656 \\
\hline 1 & B & Prophyta & 1225,125 & 1,353722059 & 58470 & 4,417669 \\
\hline 1 & B & B255 & 138,046875 & 0,911278016 & 42727 & 4,100593 \\
\hline 1 & B & Urea & 820,5625 & 1,157731404 & 30935 & 3,705568 \\
\hline 1 & B & Erwinia & 557,4375 & 1,447107669 & 52444 & 0,268411 \\
\hline 1 & B & Coniothyr. & 364,84375 & 1,968543791 & 54354 & 4,771884 \\
\hline 1 & B & Control & 224,71875 & 1,894904449 & 31904 & 8,150556 \\
\hline 2 & B & Prophyta & 725,375 & 1,976772135 & 125132 & 6,890853 \\
\hline 2 & B & B255 & 408,71875 & 1,761034274 & 62397 & 14,19629 \\
\hline 2 & B & Urea & 226,765625 & 0,274524483 & 30898 & 4,526399 \\
\hline 2 & B & Erwinia & 334,40625 & 1,496360541 & 27026 & 3,956372 \\
\hline 2 & B & Coniothyr. & 352,625 & 1,597747964 & 53360 & 8,651174 \\
\hline 2 & B & Control & 244,6875 & 1,417555182 & 28630 & 8,095002 \\
\hline 3 & B & Prophyta & 343,921875 & 1,110176576 & 51486 & 7,537923 \\
\hline 3 & B & B255 & 224,875 & 0,751639727 & 29030 & 7,49053 \\
\hline 3 & B & Urea & 194,1875 & 0,566216458 & 5777 & 2,552624 \\
\hline 3 & B & Erwinia & 203,046875 & 1,684616254 & 35965 & 4,801824 \\
\hline 3 & B & Coniothyr. & 209 & 1,695411625 & 29877 & 5,90073 \\
\hline 3 & B & Control & 970 & 1,244009249 & 83634 & 3,173397 \\
\hline
\end{tabular}

